UNIVERSIDADE de SÃo PAULO

MUSEU de ARQUeologia e ETNOLOGIA

Programa de Pós-graduação em Arqueologia

\title{
NA DIREÇÃo dAS PERIFERIAS EXTREMAS dA AMAZÔNIA: ARQUEOLOGIA NA BACIA DO RIO JIPARANÁ, RONDÔNIA.
}

Carlos Augusto Zimpel Neto

Orientadora: Prof ${ }^{\mathrm{a}} \mathrm{Dr}^{\mathrm{a}}$ Silvia Maranca 
UNIVERSIDAde de São PaULo

Museu de ARQueologia e EtNologia

Programa de Pós-graduação em Arqueologia

\begin{abstract}
NA DIREÇÃO dAS PERIFERIAS EXTREMAS dA AMAZÔNIA: ARQUEOLOGIA NA BACIA DO RIO JiPARANÁ, RONDÔNIA.
\end{abstract}

Carlos Augusto Zimpel Neto no USP: 5235620

\begin{abstract}
Dissertação apresentada ao Programa de Pós-Graduação em Arqueologia do Museu de Arqueologia e Etnologia da Universidade de São Paulo para obtenção do título de Mestre em Arqueologia.
\end{abstract}

Orientadora: Prof ${ }^{\mathrm{a}} \mathrm{Dr}^{\mathrm{a}}$ Silvia Maranca

Linha de Pesquisa: Espaço e Organização Social 
Para Clovis e Zoé, pais maravilhosos que cada vez mais me dão exemplo para persistir. 
He is not dead, who is still fighting back.

Brochado (1984), no epílogo de sua tese, traduzindo o provérbio gaucho: Não tá morto quem peleia. 


\section{Agradecimentos}

Agradeço a Prof $\stackrel{a}{\text {. Dra }}$. Silvia Maranca, pela paciência, dedicação e orientação, mas principalmente pelas conversas que tivemos. Teu exemplo de dedicação e luta à arqueologia vou carregar comigo pelo resto da vida.

À $\mathrm{Dr}^{\mathrm{a}}$ - Solange Caldarelli, coordenadora geral da SCIENTIA CONSULTORIA CIENTÍFICA, que gentilmente cedeu toda sua infra-estrutura, staff, além de ser a incentivadora maior desta pesquisa.

À Dr $r^{a}$ Dirse Kern que em campo compartilhou seu vasto conhecimento, e que em laboratório auxiliou-me em muito para a construção deste trabalho. Também sou muito grato pelas análises de Textura do solo, pela gentileza de ceder seu tempo e equipe para a organização e interpretação dos solos arqueológicos tratados nesta dissertação.

A Prof ${ }^{a}$ Dr $^{\mathrm{a}}$ Marisa Coutinho Afonso, que me abriu as portas no Museu de Arqueologia e Etnologia, e nestes anos convívio foi alguém com quem eu sempre pude contar, obrigado.

Ao prof. Dr. Eduardo Goes Neves, pelo incentivo a encarar o desafio de trocar de tema no meio do mestrado, e pelas conversas durante a elaboração. Muito obrigado.

Ao prof. Dr. André Soares, da Universidade Federal de Santa Maria, que foi o responsável pela minha entrada na arqueologia, me aceitando como estagiário no LEPA/UFSM, mas principalmente pelo incentivo constante que foi necessário ao iniciar a minha formação.

Ao prof. Dr. Saul Milder, pelos anos de orientação na iniciação científica, pelos conhecimentos compartilhados, mas sobretudo, pela longas andanças desde as missões até a fronteira oeste, onde vivi coisas que nenhum CTG pode contar, encontrando os reais valores da nosso cultura gaucha.

Aos colegas do LEPA Alexandre Pedrozo, Lucio Lemes, Guilherme Schmidt, Guilherme Correa, Neli Machado, Juliana Santi, Silvana Suze, Sandor Bringmann e João (o melhor rancheiro que uma equipe de campo pode ter!)

A toda equipe da SCIENTIA AMAZÔNIA, e principalmente à Fernanda AraujoCosta, que nos acolheu em Belém-PA, uma terra tão estranha a primeira vista, mas que aos poucos começo compreender melhor. Isabel, Célia, André, Lucio, Joana, Greyce, Thiago, muito obrigado

À Ms. Ana Lucia Machado, sem teus conhecimentos e ensinamentos a análise das evidencias cerâmicas seria impossível. Teus ensinamentos sobre a vida de 
um arqueólogo na Amazônia guardo comigo, sinto saudades de nossas conversas.

A $\mathrm{Dr}^{\mathrm{a}}$ Sirlei Hoeltz, pela coordenação e orientação em campo e pela gentileza de ceder os dados sobre o material lítico.

A Wanderson Esquerdo, que gentilmente forneceu os dados para elaboração dos croquis e imagens, e pela paciência que teve comigo em campo, muito obrigado.

Ao Osni pela eficiência na logística de campo em Rondônia

A toda equipe da Seção Acadêmica do MAE/USP, pela competência na prestação dos serviços e pelos conselhos dados durante minha estada no Museu.

Modéstia a parte, agradeço ao meu GRÊMIO, imortal tricolor da pampa querência amada, pessuelo que me ajuda matar a saudade do pago, ganhasss ou percass eu te sigo aonde for.

A Daniel Cruz e Lilian Panchuk, amigos que a arqueologia me proporcionou, em nossas longas conversas ainda vamos resolver os problemas da arqueologia brasileira. Que o futuro seja próspero para vocês neste desafio de encarar a selva amazônica de frente, vida longa!

A minha irmã Mariana, que agora longe me faz perceber o quão importante era a tua presença aqui, teus ensinamentos e discretos gestos me ajudaram a encarar a ida pra cidade grande e, principalmente, me fez ter um lar mesmo estando quilômetros de distância dele.

Ao Pai e a Mãe, que por tanto tempo vem me ensinando cada vez mais, o incentivo de vocês, e sobretudo a confiança, fazem com que eu me sinta livre, e a liberdade de escolha, a autodeterminação são valores enraizados em mim que pretendo passar adiante.

Paula, sem teu carinho e dedicação ao longo destes anos este trabalho não seria só impossível, mas sobretudo, INCOMPREENSíVEL, esta dissertação também é dedicado a ti, minha guria. 


\section{Resumo}

Na direção das periferias extremas da Amazônia: arqueologia na bacia do rio Jiparaná-RO

O trabalho intitulado $\mathrm{Na}$ direção das periferias extremas da Amazônia: arqueologia na bacia do rio Jiparaná-RO tem como objetivo debater tópicos específicos da arqueologia no estado de Rondônia, as evidências cerâmicas e a Terra Preta Arqueológica. Isto para podermos ter uma melhor compreensão da ocupação do Sítio Encontro, objeto de estudo desta dissertação. O sítio litocerâmico Encontro (RO-MA-05) localiza-se na direção das áreas periféricas do sudoeste amazônico. Situado no município de Ministro Andreazza, está inserido na serrania da Providência, adjacente a planície de inundação do rio Jiparaná, Rondônia. Trata-se de um assentamento pequeno, considerando os padrões amazônicos que até o momento atesta a mais antiga manifestação de terra preta arqueológica associada a vestígios cerâmicos na Amazônia. Buscando trazer dados antes pouco debatidos (principalmente a produção do arqueólogo Eurico Miller) é que propomos a retomada dos estudos na região, com auxilio de informações e dados somente agora disponíveis e que podem remeter a área do sudoeste amazônico como importante ponto de averiguação de questões que abarcam as primeiras expansões dos grupos Tupi e as origens da agricultura.

Palavras-chave: Arqueologia, Amazônia, Rondônia, cerâmica, terra preta arqueológica. 


\section{Abstract \\ On the direction of the Amazonian southwest periphery: archaeology in the Jiparaná basin, Rondonia,}

This dissertation, On the direction of the Amazonian southwest periphery: archaeology in the Jiparaná basin, Rondonia, has as aim objective discuss some aspects found in the archeology of Rondonia State: pottery production and the Archaeological dark earth. Made this, we can have a better comprehension of the occupation of the Encontro archaeological site, object of study in our research. The Encontro site has evidence of litic and pottery sherds, and is located in the direction of the Amazonian southwest periphery, in Ministro Andreazza city, Rondonia State. Comparing to other samples of Amazonian archeological sites, this is a small place, but has the oldest evidence of archeological dark earth associated with ceramic known until now in Amazon. In pursuit of take again in the discussion the data available for the area(until now not too much discussed, mainly the papers of the archeologist Eurico Miller) is that we propose bring back the study of this region, aided by data just now available that refer the Amazonian southwest as an important point of discussion on questions that involve the firsts Tupi expansions and the origins of agriculture.

Key-words: Archaeology, Amazonia, Rondonia, pottery, Archaeological dark earth. 


\section{SUMÁRIO}

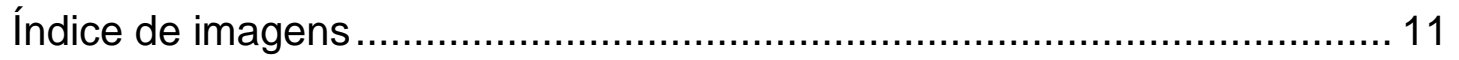

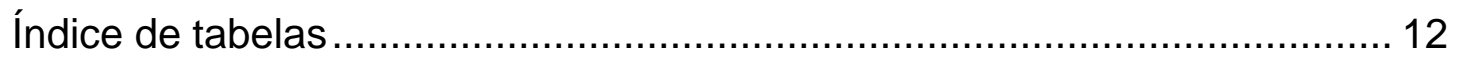

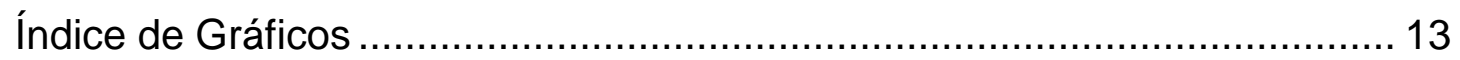

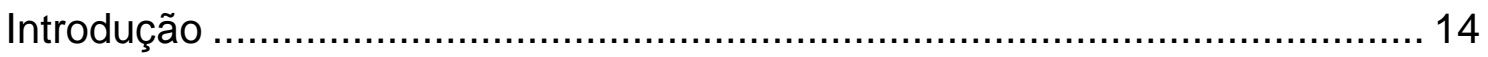

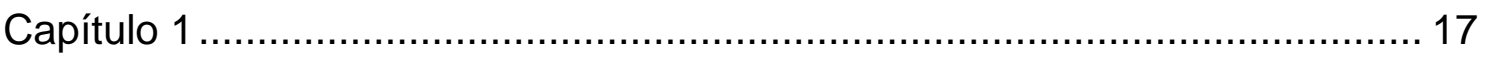

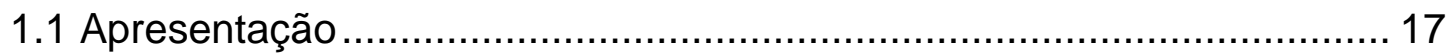

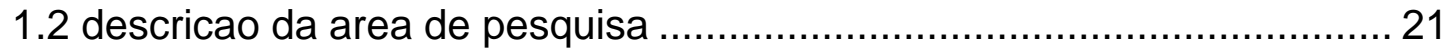

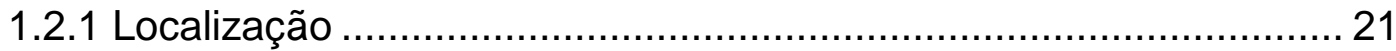

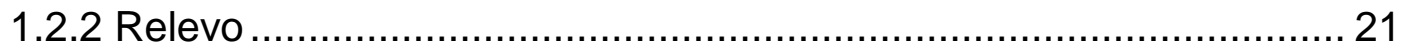

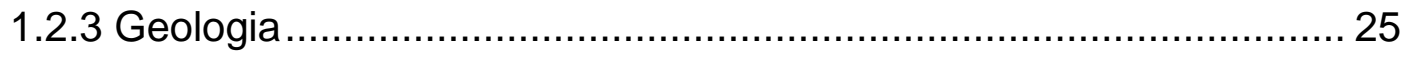

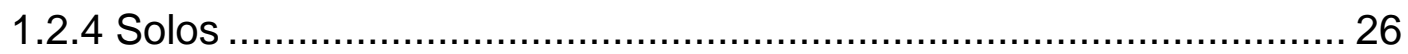

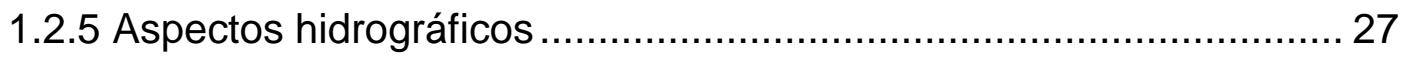

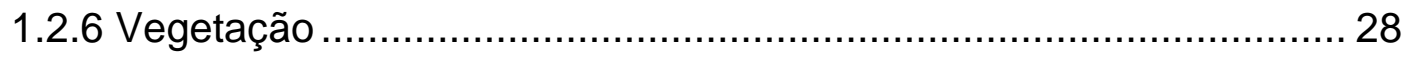

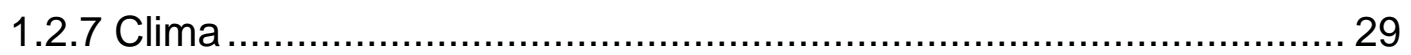

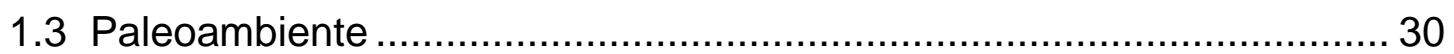

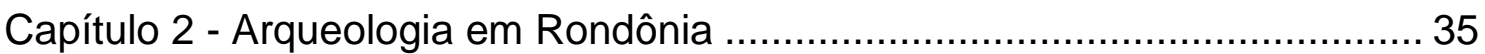

2.1 Primeiros indícios - os antigos sítios líticos e a cerâmica incipiente....... 35

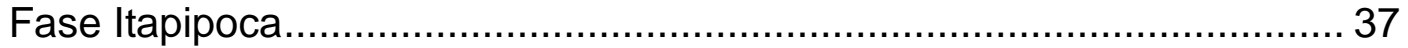

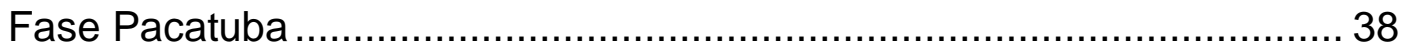

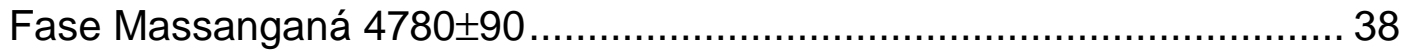

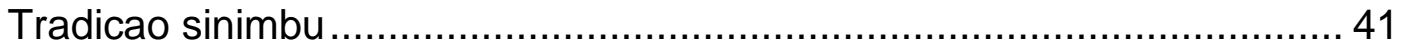

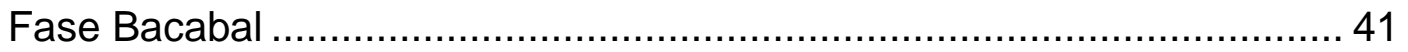

2.20 espraio das evidências cerâmicas ................................................... 44

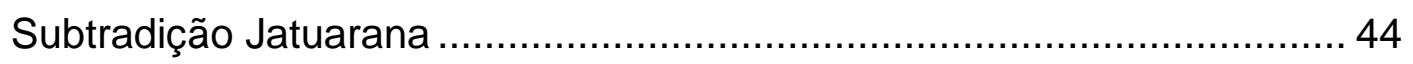

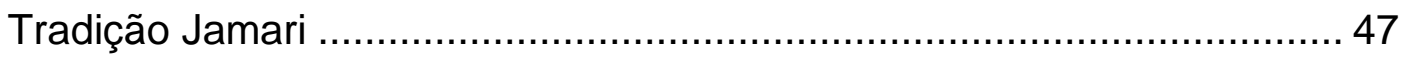

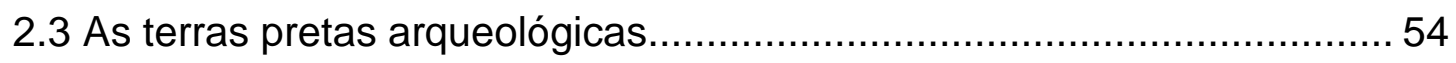




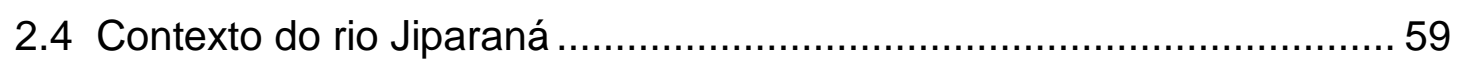

CAPÍTULO 3 - Sítio Encontro (RO-MA-05) ….................................................. 75

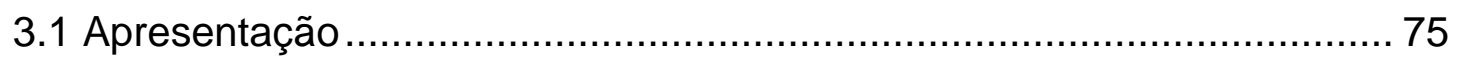

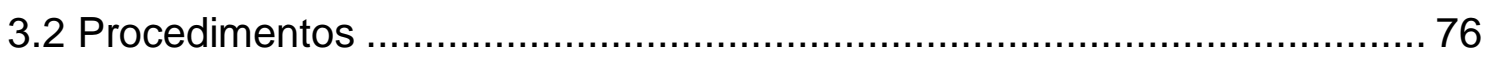

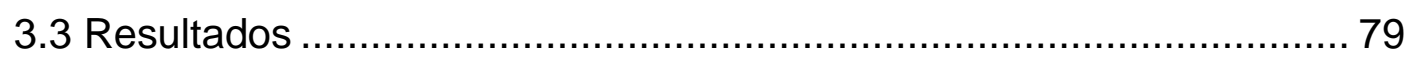

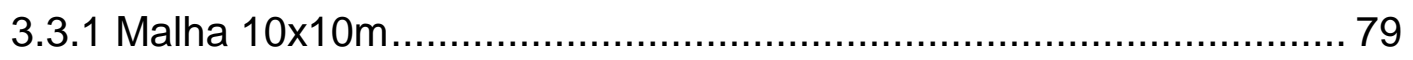

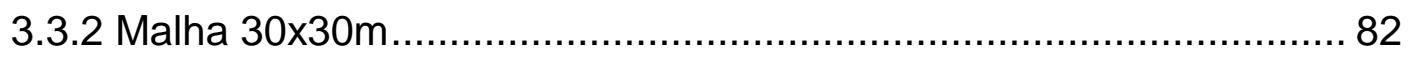

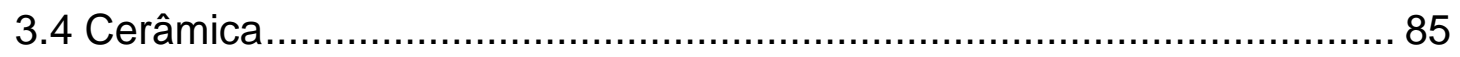

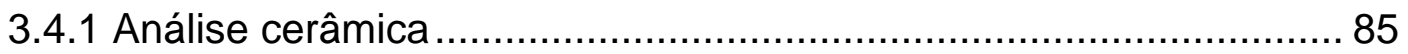

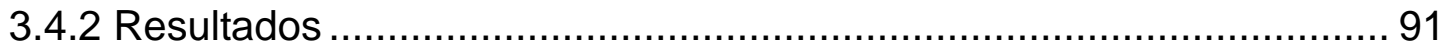

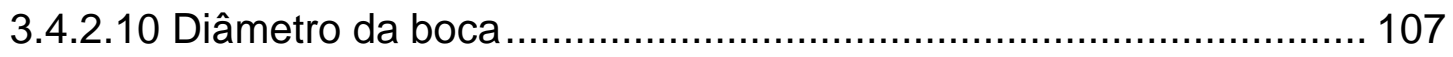

3.5 Qualificação dos atributos - caracterizando a indústria cerâmica do sítio

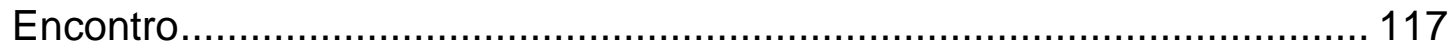

3.5.1 Caracterização da indústria cerâmica do sítio Encontro. ................ 129

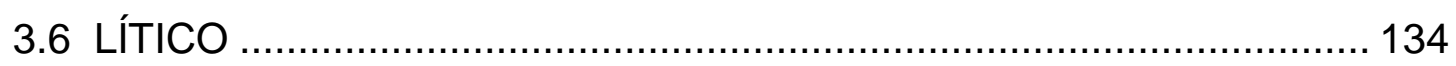

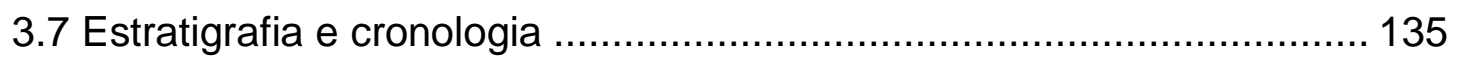

3.7.1 Registro dos dados estratigráficos ............................................ 137

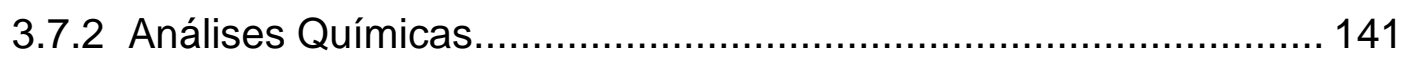

3.7.3 Cronologia e indicadores paleoambientais.................................... 149

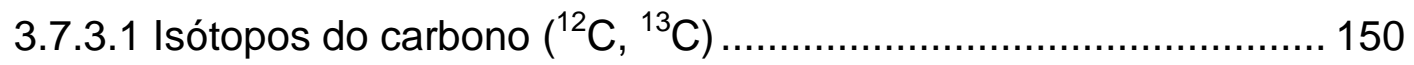

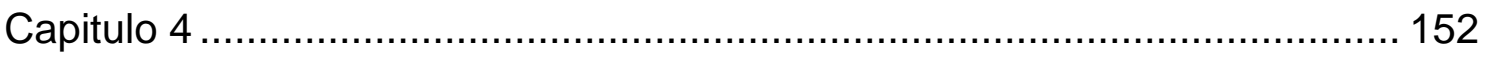

Na direção das periferias extremas da Amazônia........................................ 152

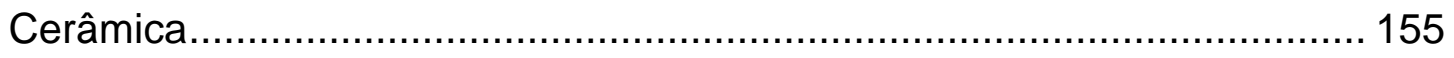

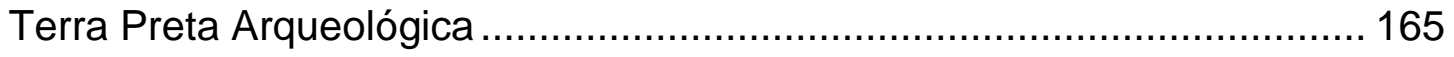

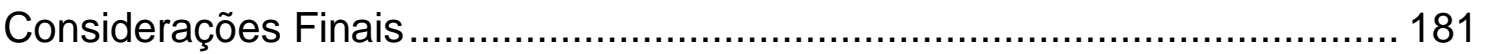

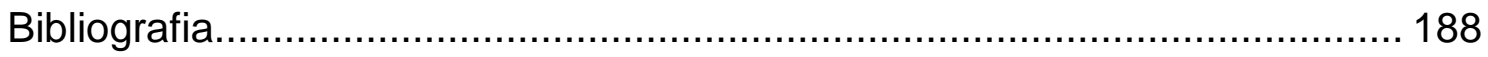




\section{ÍNDICE DE IMAGENS}

Imagem 1: Localização do Estado de Rondônia e hachurado a localização da Carta SC.20-Porto Velho Fonte: Projeto RADAM, vol. 16, 1978.

Imagem 2 - Unidades geomorfológicas. O ponto indica a localização do sítio Encontro. Projeto RADAM (1978) Carta SC.20-Porto Velho

Imagem 3 - perfil esquemático com, dados altimetricos. Carta SC.20-Porto Velho. (ProjetoRADAM, 1978).

Imagem 4 - Altitudes no Estado de Rondônia, Fonte: Atlas do Estado de Rondônia, Editora Trieste (2002).

Imagem 5: Geologia do Estado de Rondônia. Fonte: Ministério do Meio Ambiente, MMA.

Imagem 6 - Solos do Estado de Rondônia, MMA.

Imagem 7: Município, estradas e principais rios da região em estudo. Fonte:

Projeto RADAM (1978)

Imagem 8: Vegetação, fonte: MMA.

Imagem 9 - à esquerda a classificação do clima segundo Koppen,Fonte: Projeto

RADAM (1978), Carta SC.20-Porto Velho, p.259-260.....

Imagem 10: três cenários propostos para o paleoclirma..

Imagem 11: Tradições, Fases e Sítios Arqueológicos no Estado de Rondônia....... Imagem 12 - Localização dos sítios líticos no rio Jamari.(Miller et alli 1992, p.58, fig. 62).

Imagem 13 - Sítio da fase Massangana, Fonte: Miller et alli (1992).

IMAGEM 14 - MATERIAL LITICO DO RIO Jamari Miller etalli 1992.

Imagem 15 - Fases cerâmicas do sudoeste amazônico. Fonte: Miller (1999).......

Imagem 16: Localização dos sítios, por fases arqueológicas, no alto rio Madeira. (Miller, 1992, p.226).

Imagem 17: localização dos sítios cerâmicos no rio Jamari. Fonte: Miller et al.

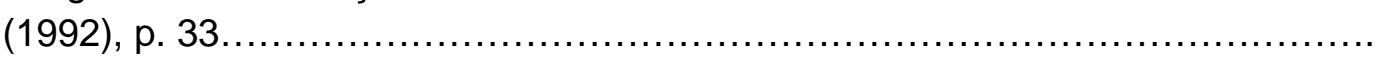
Imagem 18.

Imagem 19.

Imagem 20: Sítios arqueológicos com TPA, no médio Jiparaná, localizados por Miller (1987).

Imagem 21 - sítio no Jiparaná

Imagem 22

Imagem 23.

Imagem 24

Imagem 25

Imagem 26: Perspectiva SE do Sítio Encontro. Foto: Sirlei Hoeltz.

Imagem 27: pisoteamento do gado e construções que impactaram o assentamento.

Imagem 28: planimetria do sítio Encontro.

Imagem 29: a esquerda sondagem S4 E28, S22 E4, S20 W11 ..........................

Imagem 30 densidade cerâmica malha 10x10 ............................................... 81

Imagem 31: a esquerda, escavação da malha 30x30m, sondagem S49 E54 e $35 \mathrm{~S} / 31 \mathrm{~W}$

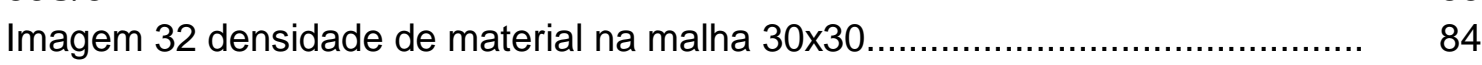

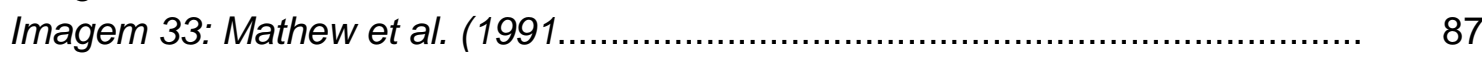

Imagem 34: Barraclough (1992) apud Orton et alli (2003) ................................. 88 
Imagem 35 : cores da pasta identificadas ....................................................... 98

Imagem 36: fragmento En-924 em diferentes perspectivas. ............................. 99

Imagem 37: fragmento En-1463............................................................ 101

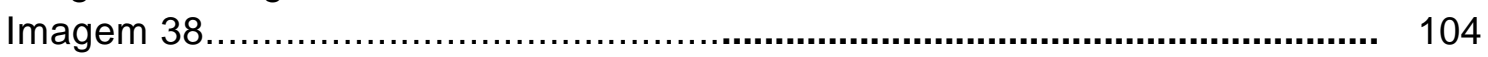

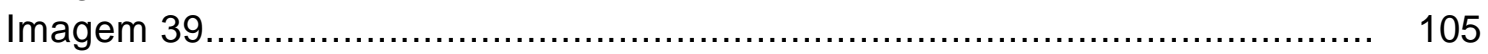

Imagem 40 : bases planas identificadas...................................................... 108

Imagem 41: fragmento entalhado.......................................................... 108

Imagem 42: fragmentos corrugados.......................................................... 110

Imagem 43: fragmentos roletados ........................................................ 110

Imagem 44: incisos em bordas reforçadas..................................................... 111

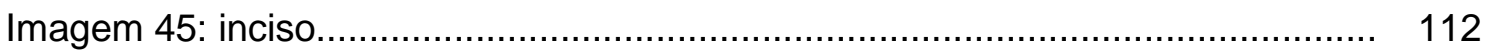

Imagem 46: ungulado e corrugado-ungulado.................................................. 113

Imagem 47: borda com reforço ungulada, En-676-679.................................. 113

Imagem 48: a esquerda, pintura branca, centro e direita, pintura preta................ 114

Imagem 49: fragmentos com engobo vermelho ............................................. 115

Imagem 50 motivos de pintura identificados................................................ 116

Imagem 51: machados resultado da escavação e de coleta de superfície............. 134

Imagem 52: líticos polidos em quartzo........................................................... 135

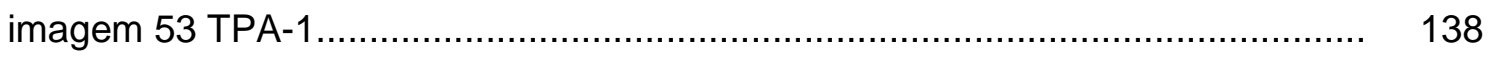

imagem 54 TPA-2 …......................................................................... 139

Imagem 55: reprodução parcial do mapa de Schmitz (1991, p.56) ...................... 159

Imagem 56 figua cronolgias e tpa................................................................ 185

\section{ÍNDICE DE TABELAS}

Tabela 1 - Fases cerâmicas no rio Jiparaná. (A partir de Miller, 1987a,1987b).. 63

Tabela 2: Quantidade de material................................................................ 78

Tabela 3: Quantidade de material cerâmico por nível........................................ $\quad 78$

Tabela 4: Quantidade de fragmentos cerâmicos por nível na sondagem N4

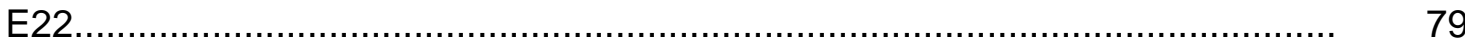

Tabela 5: Quantidade de Material escavado na malha..................................... 81

Tabela 6: Quantidade e densidade de material cerâmico por nível na malha $30 \times 30 \mathrm{~m}$.

Tabela 7: Resultado da escavação da sondagem S49 E54.............................. 82

Tabela 8: dados do gráfico 27 ........................................................................ 125

Tabela 9: Quantidade de cerâmica escavada em relação aos níveis artificiais e aos horizontes pedológicos da TPA-1

Tabela 10: Quantidade de cerâmica escavada em relação ao níveis artificiais e os horizontes pedológicos da TPA-2

Tabela 11: textura dos solos na área adjacente (valores em porcentagem)...... 140

Tabela 12: Valor do $\mathrm{pH}$........................................................................... 141

Tabela 13: valores de M.O., P, Na, K, Ca, Mg. .............................................. 142

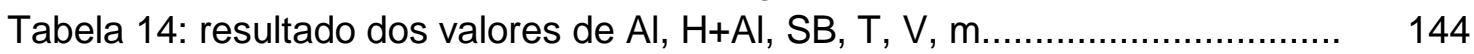

Tabela 15: valores de B, Cu, Fe, Mn, Zn..................................................... 145

Tabela 16: Resultado das datações radiocarbônicas ....................................... 148

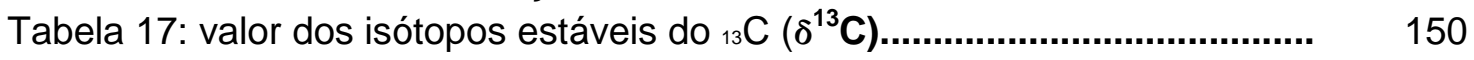




\section{ÍNDICE DE GRÁFICOS}

Gráfico 1 : Resultado da triagem.............................................................. 91

Gráfico 2: Técnica de manufatura.............................................................. 92

Gráfico 3: Tipo de Antiplástico identificado....................................................... 93

Gráfico 4: Tipos de antiplástico mineral.......................................................... 93

Gráfico 5: Freqüência do antiplástico........................................................ 94

Gráfico 6: Ordenação do antiplástico......................................................... 95

Gráfico 7: dimensão do antiplástico.............................................................. 95

Gráfico 8: Tipos de queima identificados....................................................... 96

Gráfico 9: Quantidade de fragmentos por cor da pasta identificados.................. 97

Gráfico 10: Resultado da quantidade de cerâmica por tipo de cor....................... $\quad 97$

Gráfico 11: Presença de barbotina............................................................... 99

Gráfico 12: espessura dos fragmentos......................................................... 101

Gráfico 13: Quantidade de bordas por morfologia........................................... 102

Gráfico 14: Freqüência dos tipos de lábio identificados...................................... 106

Gráfico 15: relação morfologia da borda/tipo de lábio....................................... 106

Gráfico 16: Diâmetro das bordas.................................................................. 107

Gráfico 17: Tipos de decoração plástica........................................................ 109

Gráfico 18: presença de decoração entre bordas reforçadas. ............................ 112

Gráfico 19: Tipos de decoração pintada, ................................................... 114

Gráfico 20: dimensões do antiplástico........................................................ 118

Gráfico 21: proporção dos tipos de ordenação do antiplástico nas diferentes 119 cores identificadas.

Gráfico 22: proporção da freqüência do antiplástico entre as diferentes cores.... 120

Gráfico 23: Seriação ............................................................................. 121

Gráfico 24: tipos de tratamento de superfície entre as diferentes cores. Os 122 dados da tabela acima são porcentagens.

Gráfico 25: proporção de fragmentos com barbotina entre as cores..................... 123

Gráfico 26 : Distribuição dos tipo de cor de pasta entre as medidas de 124 espessura $(\mathrm{em} \mathrm{cm})$ dos fragmentos identificados.

Gráfico 27 : distribuição dos tipos relacionados a morfologia da borda entre as 124 diferentes cores de pasta.

Gráfico 28: tipo de decoração plástica relacionados a cor dos fragmentos.......... 126

Gráfico 29: proporção de tipos com pintura entre as diferentes cores................. 127

Gráfico 30: Datações calibradas no aplicativo Calib 5.1 .................................. 149 


\section{INTRODUÇÃO}

Ao depararmos com dados relacionados à Floresta Amazônica, é habitual encontramos números grandiosos. Tal magnitude da região abriga que a maior floresta tropical do planeta vem sendo estudada em diversas áreas do conhecimento. Atualmente, é possível elencar pesquisas das mais diversas áreas: paleoambiente, lingüística, antropologia, botânica, que abocam a parte sudoeste do território, como importante ponto para o entendimento de questões como: a expansão/recuo da floresta sobre campos teve durante os últimos milênios (Freitas 1996, Pessenda 2001), as primeiras expansões dos grupos falantes Tupi (Rodrigues,1964, Migliazza,1982) e as origens do cultivo da mandioca na América. (Olsen e Schaal, 1998)

Principalmente nas duas últimas décadas, devido à arqueologia de licenciamento ambiental, é que em áreas longínquas, antes de pouco interesse cientifico, ou de difícil acesso, estão sendo realizadas pesquisas arqueológicas. É claro que o PRONAPA e seus respectivos programas, como o PROPA e o PRONAPABA contribuíram em muito, e é a partir destes que a maioria das pesquisas arqueológicas se norteiam, mas dada as dimensões continentais de nosso país, pode-se dizer que somente agora estamos conseguindo atingir as últimas fronteiras arqueológicas.

Neste cenário, já alguns anos se passaram desde que o arqueólogo Eurico Theofilo Miller conseguiu percorrer grande parte do Estado de Rondônia e sistematizou achados em fases, tradições e subtradições arqueológicas que se espalham por praticamente todo território ${ }^{1}$. O sudoeste amazônico está quase em sua totalidade no Estado de Rondônia, e sobre a arqueologia deste Estado que esta pesquisa está concentrada.

O espaço do que caracterizamos como sudoeste amazônico é formado pela bacia do rio Madeira, incluindo seus formadores, o rio Guaporé e o rio Mamoré,

\footnotetext{
${ }^{1}$ Os locais onde houveram pesquisas no estado foram: o Rio Guaporé, o Pantanal do Guaporé, - Alto Rio Madeira, e a bacia do rio Jamari. Estes dados estão publicados em Miller (1983, 1987, 1992, 1999), Miller et alli (1992), Miller e Caldarelli (1987) e Miller e Meggers (2003).
} 
tendo ao norte o rio Madeira, a leste o rio Roosevelt, e ao sul os limites com a bacia do rio Paraguai.

Grande parte das pesquisas é produto de estudos sobre o impacto de obras de grande no Estado de Rondônia. Como resultado, tem-se para alguns pontos do estado pesquisas arqueológicas que atestam longas seqüências de datações, praticamente sem hiatos. Os dados indicam uma ocupação contínua de pelo menos 9000 anos. (cf. Miller, 1983, 1992, 1999 e Miller et alli, 1992)

É em Rondônia que encontramos uma das mais antigas Terras Pretas Arqueológicas da Amazônia, atribuída à fase pré-cerâmica Massangana, datando 4730 \pm 50 AP. (Miller et. alli. 1992, Miller e Meggers, 2003).

Esta dissertação foi viabilizada a partir de um projeto de arqueologia de licenciamento ambiental. Os dados inéditos aqui apresentados são procedentes do Projeto Arqueologia Preventiva na Expansão do Sistema de Transmissão Acre-Rondônia, executado pela Scientia Consultoria Científica ${ }^{2}$, contratada pela Centrais Elétricas do Norte do Brasil S.A. (ELETRONORTE). Especificamente, as informações provêem do subprojeto 1: Salvamento Arqueológico na LT 230kV Ji-Paraná - Pimenta Bueno - Vilhena - Rondônia (SCIENTIA, 2005).

Um exemplo de ocupação em terra firme servirá de pressuposto para a discussão da arqueologia do realizada no Estado. O sítio Encontro, objeto de estudo da pesquisa, está localizado no Estado de Rondônia, e no interesse de ter uma compreensão do contexto da área fez-se a reunião dos dados produzidos basicamente pelo arqueólogo Eurico Miller, que estão publicados em artigos científicos e na forma de relatórios, nem sempre de fácil acesso. A pesquisa, portanto, também se justifica no intuito de colocar em discussão, de certa forma, a reunião destas informações assim como os dados inéditos e interpretações.

A demanda de pesquisa arqueológica que há no Estado está crescendo a passos largos - devido principalmente a construção de duas grandes usinas hidrelétricas no rio Madeira, além das diversas linhas de transmissão de

\footnotetext{
${ }^{2}$ SCIENTIA (2005)
} 
energia que deverão ser realizadas. $\mathrm{Na}$ área também está em andamento o amplo Projeto Continuidades e hiatos da Amazônia, criado e coordenado pelo Prof. Dr. Eduardo Goes Neves, desde 2006.

Sendo assim, é otimista o futuro das pesquisas arqueológicas no Estado, e esta pesquisa, neste momento inicial, pode colaborar no conhecimento produzido sobre o passado pré-colonial do sudoeste amazônico, sobretudo durante o período de 4500-2000 anos AP, além de ser fonte de consulta para estas investigações que estão por vir.

Para tanto, o texto foi organizado na seguinte forma:

No primeiro capitulo, é realizada uma apresentação do tema, a partir dos primeiros dados arqueológicos, e da caracterização da área em estudo descrição da hidrografia, geologia, relevo, vegetação, clima e paleoclima.

O segundo capitulo é dedicado a apresentação e discussão da arqueologia praticada até o momento no Estado de Rondônia, dando ênfase a área entorno do sítio arqueológico Encontro, objeto de estudo desta dissertação e assunto a ser trado no terceiro capítulo.

No terceiro capítulo abordamos especificamente os dados do sítio Encontro, os procedimentos de campos, seus resultados, a cultura material resultante das escavações e a metodologia de análise adotada, assim como os dados relacionados à estratigrafia e cronologia, que servirão de base para a discussão do capitulo final da dissertação.

No quarto capitulo são realizadas as considerações finais. É realizada uma discussão dos resultados obtidos durante as pesquisas de campo e de laboratório com alguns tópicos relacionados à arqueologia em Rondônia. 


\section{CAPÍTULO 1}

(...) Por fim repito o meu pedido de me indicar um meio para consultar o Sr. Grl. Rondon sobre certas tribos da "Rondônia" que por demais me interessam (...)

Curt Nimuendajứ

\subsection{APRESENTAÇÃo}

O território amazônico é um dos pontos de debate arqueológico atualmente mais desenvolvidos no país. As grandes questões, propostas por grandes nomes que pensaram a arqueologia amazônica estão relacionados muitas vezes à efetividade de ocupação da área. Para Meggers, por exemplo, fatores ambientais seriam responsáveis pela baixa capacidade em sustentar uma grande população, devido à instabilidade climática agravada por várias flutuações de curto e longo prazo nos últimos 5000 anos. Longos períodos chuvosos e épocas secas prolongadas interromperiam a estabilidade cultural de grupos, forçando a dispersão de comunidades, tornando-as pequenas e semi-sedentárias, diminuindo assim a possibilidade de existência de grandes e duradouros assentamentos (Meggers, 1957, 1971, 1990, 1995)

Lathrap (1970) propõe o que o jargão arqueológico chama de modelo cardíaco. Um modelo que trata a floresta tropical como um ambiente mais abundante em recursos. Os rios da bacia Amazônica e seus afluentes agiriam como artérias e veias, dispersando inovações culturais vindas do coração da floresta, resultando numa maior ocupação do território.

Tanto Meggers quanto Lathrap estabeleceram uma dicotomia no tipo de ocupação que ocorrera na Amazônia: entre a várzea e a Terra Firme. Meggers (1971) afirma que a várzea seria um ambiente mais favorável a ocupação, e os grandes sítios encontrados neste tipo de ambiente seriam explicados por

\footnotetext{
${ }^{3}$ Carta de Curt Nimuendajú para Luiz Bueno Horta Barbosa, então Diretor do Serviço de Proteção aos Índios do Rio de Janeiro em 22-jan-1921, encontrada em Nimuendajú (1993)
} 
reocupações de locais preferências. Lathrap (1970), também auxiliado em premissas ecológicas, reconhecia a dicotomia Várzea x Terra Firme, e 0 resultado disso seriam diferenças sócio-econômicas entre sociedades de ecossistemas diferentes.

Nos anos 80, o debate a respeito das origens e do desenvolvimento das populações na Amazônia foi acrescido pelas pesquisas de Roosevelt. A pesquisadora relaciona uma série de dados indiretos sugerindo que o cultivo de milho associado a outros meios favoráveis, resultou no desenvolvimento de sociedades complexas com organização social do tipo cacicado (Roosevelt 1992), opondo-se, portanto, às proposições de Meggers (1971).

Atuando na área do baixo Amazonas, a arqueóloga encontrou evidências das primeiras ocupações do território amazônico, entre 11400-10000 anos AP (Roosevelt, 1994). Neves e Petersen (2005) comentam que as ocupações iniciais foram caracterizadas por uma rápida colonização em ambientes diversos, sendo que, há cerca de 8.000 anos, diferentes partes da bacia Amazônica já eram ocupadas, incluindo locais próximos às planícies aluviais dos grandes rios, mas também áreas de terra firme, distantes dos principais cursos d'água.

$\mathrm{Na}$ Amazônia encontramos exemplos das cerâmicas mais antigas das Américas, recuando a 7500 anos AP. Também ocorrem indícios por volta de 5500 anos AP, mas aparentemente restritas, caracterizadas pela presença em sambaquis litorâneos e fluviais do baixo Amazonas e na zona de estuário (Perota \& Botelho 1992, Hilbert 1968, Roosevelt 1995, Roosevelt et alli 1991, Simões 1981).

Em outras partes da Amazônia, durante esse mesmo período, entre 7.500 a 3.500 anos BP, as evidências de produção cerâmica, e de outros tipos de manifestação humana, são raras, se não inexistentes. Temos uma idéia sobre a ocupação do inicio e do fim do Holoceno, contudo sobre o período Médio, as informações são escassas.(Neves, 2003) 
Nos últimos anos, evidências de ocupação tardia estão sendo descobertas no sudoeste paraense, referentes a indícios ligados ao Holoceno Inicial e Médio (Silveira, 1994, Kipnis, et alli, 2005, Caldarelli, et al, 2005).

Em Caldarelli et al. (2005), as datações testemunham uma ocupação de áreas a céu aberto, interpretadas como sociedades caçadoras-coletoras, de economia forrageira, por um período estimado de 5000 anos, entre 11000 e 6000 anos AP, sem indícios de cerâmica. Kipnis et. al. (2005) traz uma série datas para abrigos localizados na Serra dos Carajás, que vão de 10000 a 1580 anos AP.

$\mathrm{Na}$ busca de um refinamento das hipóteses consagradas, o desenvolvimento do Projeto arqueologia na Amazônia central (PAC), coordenado pelo Prof. Dr. Eduardo Goes Neves, próximo a Manaus, na confluência do rio Solimões e Negro conseguiu um bom conhecimento da seqüência arqueológica da área. (Neves, 2003, 2005, Lima et. al. 2006, Petersen et al. 2005) A ocupação tem o começo atestado no sítio lítico Dona Stella datado entre 7700-5280 anos AP. Neste local as pesquisas recuperaram um das poucos pontes de projétil bifacial em contexto na Amazônia. (Neves, 2003). Houve também um aprimoramento das cronologias referente as fases cerâmicas definidas por Hilbert (1968). O complexo cerâmico mais antigo revela uma datação entre 2250 - 1640 anos AP refere-se à Fase Açutuba (Lima et. al. 2000). Tal complexo está presente em vários sítios da região, entre eles Hatahara, Açutuba e Lago Grande. A fase Manacapuru (1450 - 1150 AP) é considerada como início de um processo de intensificação na exploração de recursos naturais e de modificação da paisagem, como a intensificação de terra preta arqueológica, a construção de montículos, valas defensivas e paliçadas. $O$ ápice das modificações antropogênicas na paisagem é diagnostica na fase Paredão, entre 1250 - 750 anos AP. (Neves, 2004, Petersen et al. 2005)

A formação das terras pretas nos sítios da área não está associada, como em outros casos, ao aumento da densidade e duração dos assentamentos. A rápida formação dos horizontes de TPA é encontrada principalmente no intervalo entre 1500 - 850 anos AP. (Neves, 2003 e Petersen et. al. 2005). A dinâmica de formação e abandono dos assentamentos segundo os autores 
pode ter sido motivada pelo esgotamento dos recursos, ou por flutuações climáticas, como aponta Meggers. Contudo os pesquisadores indicam que as hipóteses levantadas pela pesquisadora tendem a simplificar processos que podem ter características mais complexas. As evidências levantadas propõem que 0 abandono dos assentamentos seria resultado de possíveis conflitos internos entre grupos, pela disputa de território e não somente a fatores ambientais.

A cerâmica do leste amazônico também tem sido recente alvo de discussão. Almeida (2008) realiza um balanço do estudo das fases do médio e baixo rio Tocantins, que ocorre entre século VIII ao XVII. Conclui que, sobretudo devido a variabilidade cerâmica em diversos aspectos, os traços dos Tupi do leste amazônico, podem ser inserido no denominado complexo Tupi da Amazônia oriental.

Estes dados recentes estão dando inicio à interpretação sobre novas regiões específicas, que paralelamente remontam questões abarcadas pelos principais e mais discutidos modelos de interpretação do povoamento do território Amazônico. Pensamos que em ambos levaram-se em consideração os dados provindos dos grandes rios bacia Amazônica. Pouco se sabia na época sobre como se deu a ocupação em terra firme, dados sobre as áreas de interflúvio e sub-bacias de menor porte, como vimos, também não estavam disponíveis.

Assim como no baixo amazonas, Rondônia atesta uma longa seqüência cronológica de ocupação, praticamente sem hiatos, em um período que compreende 9000 anos de historia. .(cf. Miller, 1983, 1987, 1992, 1999 e Miller et alli, 1992). Conforme Miller (1999), e como veremos adiante, tendo diferentes habitats: de terra firme e de várzea, savanas, planícies de inundação, pantanais, e informações cronológicas destes diferentes ambientes, Rondônia poderia ser um local apropriado para auxiliar no entendimento das formas de ocupação e desenvolvimento cultural da Amazônia pretérita. 


\subsection{DESCRICAO DA AREA DE PESQUISA}

$\mathrm{Na}$ organização dos dados descritivos, procuramos elencar as áreas onde houveram pesquisas arqueológicas no Estado de Rondônia ${ }^{4}$, citadas no próximo capítulo. Vamos tratar de uma maneira especial o espaço onde está inserido o sítio arqueológico em estudo.

\subsubsection{Localização}

O Estado de Rondônia está localizado na porção sudoeste da Amazônia entre os paralelos $8^{\circ} \mathrm{e} 13^{\circ} \mathrm{e}$ os meridianos $60^{\circ} \mathrm{e} 66^{\circ}$. Em quase em toda a sua totalidade é parte integrante da Amazônia legal brasileira. Possui diferentes habitats: de terra firme e de várzea, planícies de inundação, algumas concentrações de savanas e pantanais.

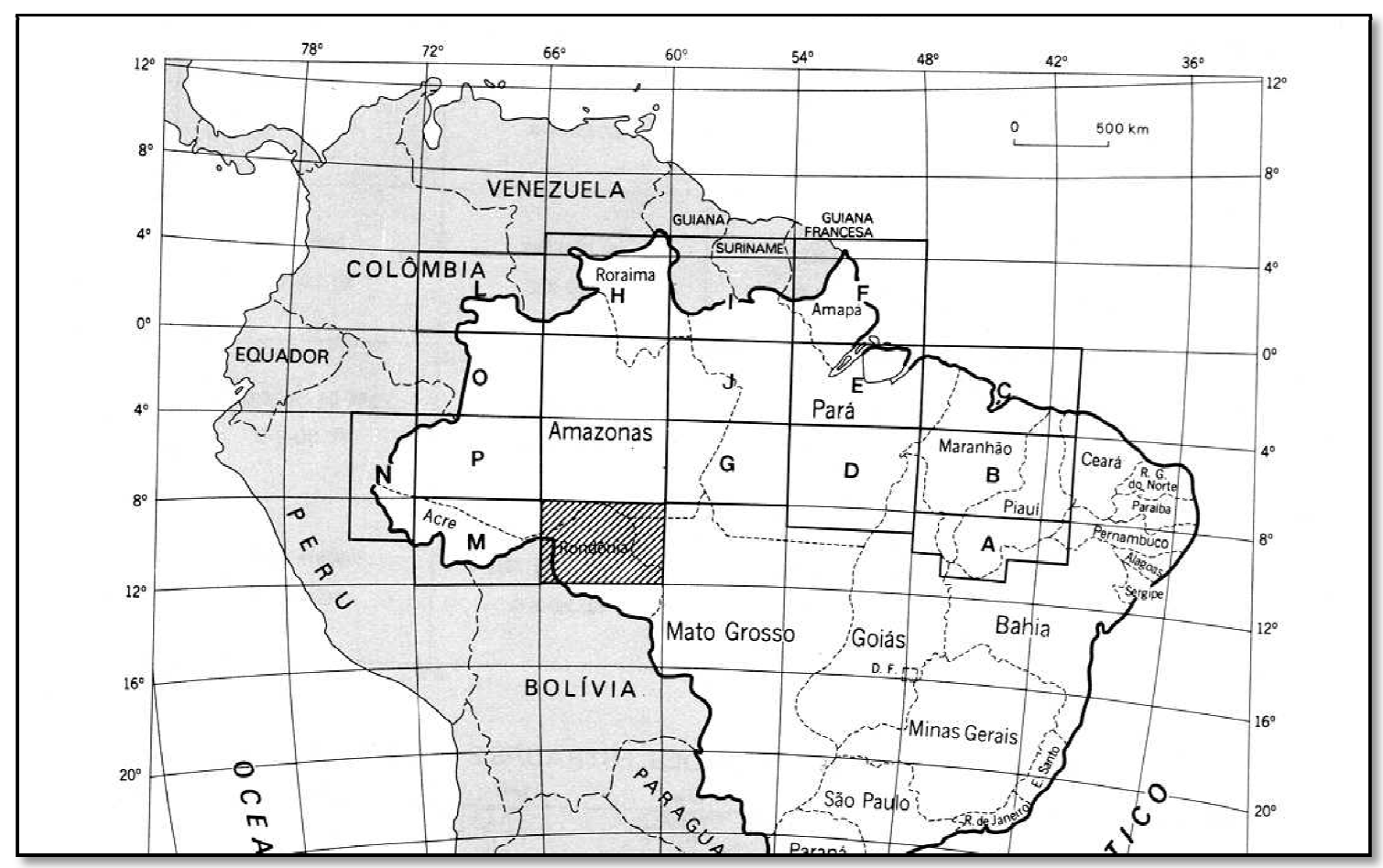

Imagem 1: Localização do Estado de Rondônia e hachurado a localização da Carta SC.20Porto Velho Fonte: Projeto RADAM, vol. 16, 1978

\subsubsection{Relevo}

Do ponto de vista da compartimentação topográfica o Estado de Rondônia apresenta-se muito diversificado. Varia de alguns metros acima do nível do mar até altitudes acima de $1.000 \mathrm{~m}$. O ponto mais alto de Rondônia está localizado

\footnotetext{
${ }^{4}$ Miller (1983, 1987,1992,1999), Miller et alli (1992), Miller e Caldarelli (1987) e Miller e Meggers (2003)
} 
na Serra dos Pacaás Novos, com altitude de $1.126 \mathrm{~m}$, conhecido como pico Jaru. Ao norte pode ser tida como topograficamente integrada à chamada Planície Amazônica. Com terras baixas aplainadas, no geral alagadiças é onde se encontram as menores cotas altimétricas, Para noroeste e nordeste, respectivamente, manifestam-se as primeiras elevações consideráveis, com as serras dos Três Irmãos e da Fortaleza e a serrania do Candoblé. (RADAM,1978)

Os relevos mais altos ocupam a parte meridional, se estendendo descontinuamente na direção oeste-leste, desde a margem direita dos rios Madeira e Mamoré até a bacia do Alto Rio Roosevelt, abrangendo diversas serras com características geomorfológicas e topográficas bem diferenciadas. Essa diversificação de aspectos permitiu identificar na área oito unidades geomorfológicas para a região(idem).

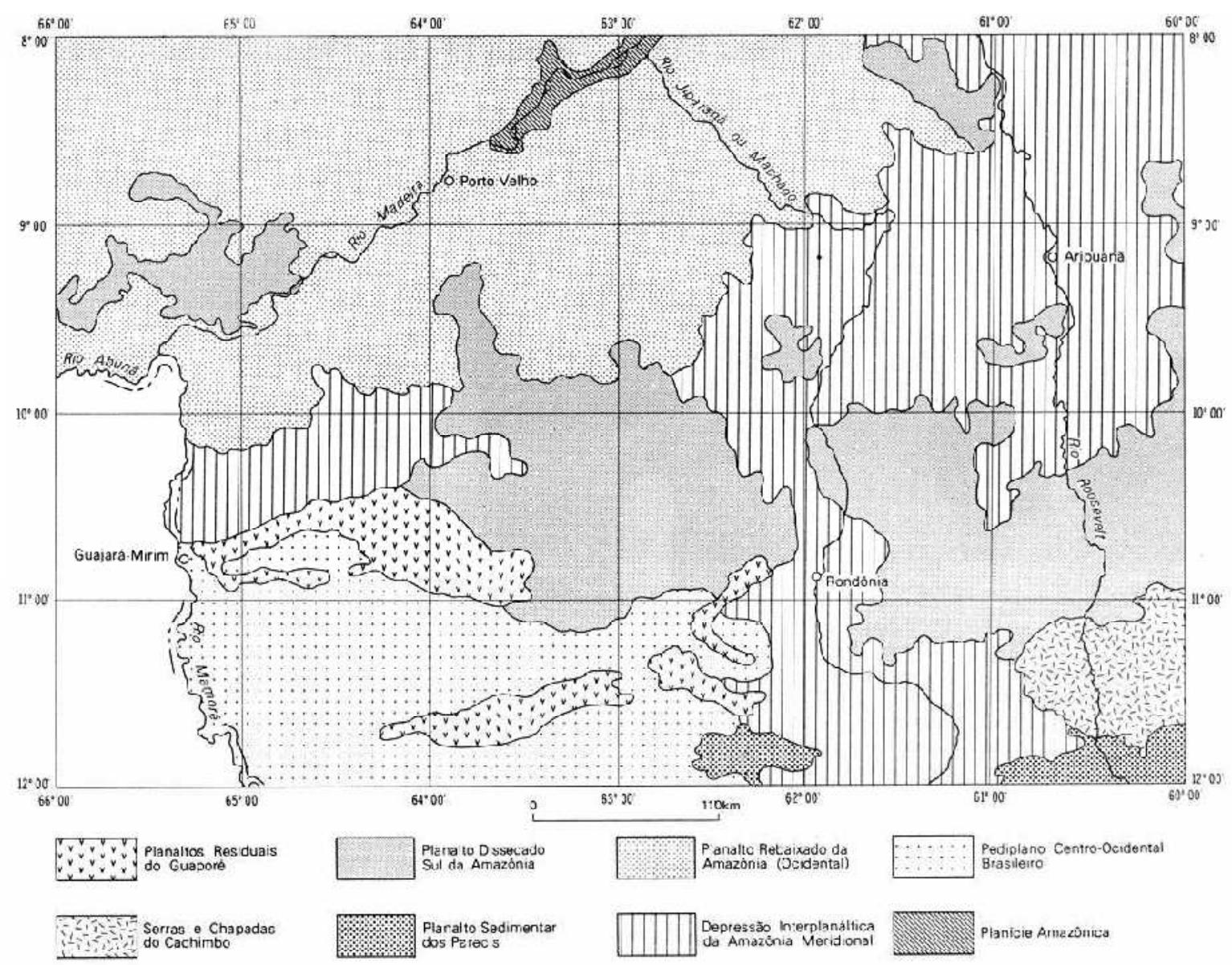

Imagem 2 - Unidades geomorfológicas. O ponto indica a localização do sítio Encontro. A localidade Rondônia indicada no mapa atualmente é o município de Ji-Paraná. Projeto RADAM (1978) Carta SC.20-Porto Velho 
A Depressão Interplanáltica da Amazônia Meridional se estende por toda área oriental do Estado, ampliando suas dimensões na parte norte. Segundo RADAM (1978) possui relevo em colinas e interflúvios tabulares, dominando paisagens de relevo suave ondulado e plano.

A Planície Amazônica encontra-se restrita ao trecho onde o rio Madeira elaborou uma faixa de aluvião sobre terrenos sedimentares. Ocorrem tanto áreas de planície, como áreas de terraços. Caracteriza-se por apresentar superfície aplainada, típica de floresta. As altitudes nesta unidade variam de 90 a 200 metros acima do nível do mar.

O Planalto Dissecado Sul da Amazônia compõe uma unidade bastante fragmentada. O sítio Encontro está próximo a parte seccionada por uma interpenetração da Depressão Interplanáltica da Amazônia Meridional. Em decorrência de sua fragmentação, limita-se com quase todas as demais unidades de relevo da área, com exceção do Planalto Sedimentar dos Parecis. É um relevo com características geomorfológicas semelhantes, representadas predominantemente por um relevo dissecado em cristas, e por serras, como: a dos Três Irmãos, a da Providência, a do Machado e a serra Sargento Paixão.

Apresenta prolongamentos: para oeste - balizado pelo Rio Madeira e envolvendo o conjunto de serras denominado Três Irmãos; para o norte - partir da margem esquerda do rio Roosevelt, abrangendo a serra do Machado; e para o centro da folha, na margem esquerda dos rios Roosevelt e Jiparaná, onde o prolongamento é definido por duas áreas nucleadas, configurando relevos dissecados em cristas com desníveis altimétricos relativos de 100150m. O Planalto Dissecado Sul da Amazônia estende-se também para o nordeste da área mapeada, no interflúvio dos rios Guariba/Aripuanã, fato assinalado pela serra do Pajurá

Os relevos apresentam-se dissecados em cristas com vertentes muito pronunciadas, que se comportam como relevos residuais, conforme a imagem 3. 


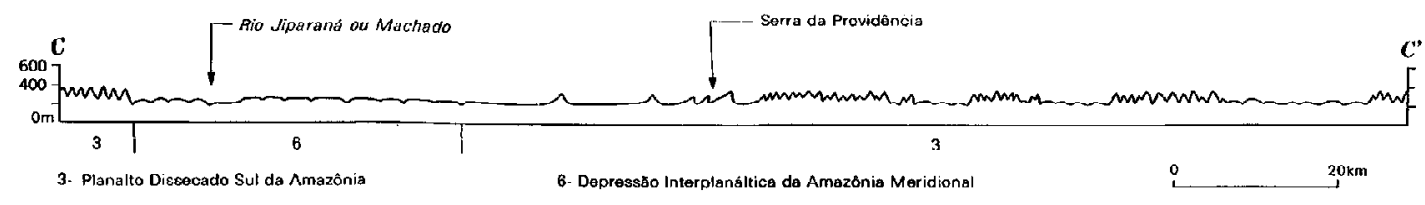

Imagem 3 - perfil esquemático com, dados altimetricos. Carta SC.20-Porto Velho. (ProjetoRADAM, 1978)

O trecho do planalto, drenado pelos rios Jiparaná e Roosevelt constitui a segunda área mais continua da unidade e se encontra separada do primeiro segmento descrito apenas por uma interpenetração da Depressão Interplanáltica da Amazônia Meridional. A dissecação é muito intensa e a feição do relevo é bastante diversificada, embora predomine o aspecto de cristas. A leste do rio Jiparaná, se observa a serra da Providência.

Tanto o Jiparaná quanto o Roosevelt seguem na direção geral sul-norte, o Jiparaná muda um pouco sua direção antes de chegar no Madeira. Ambos os rios cortam o planalto sem constituir planície. Apesar da considerável largura da seção molhada, esses rios se encontram bastante encaixados apresentando barrancas em suas margens. 


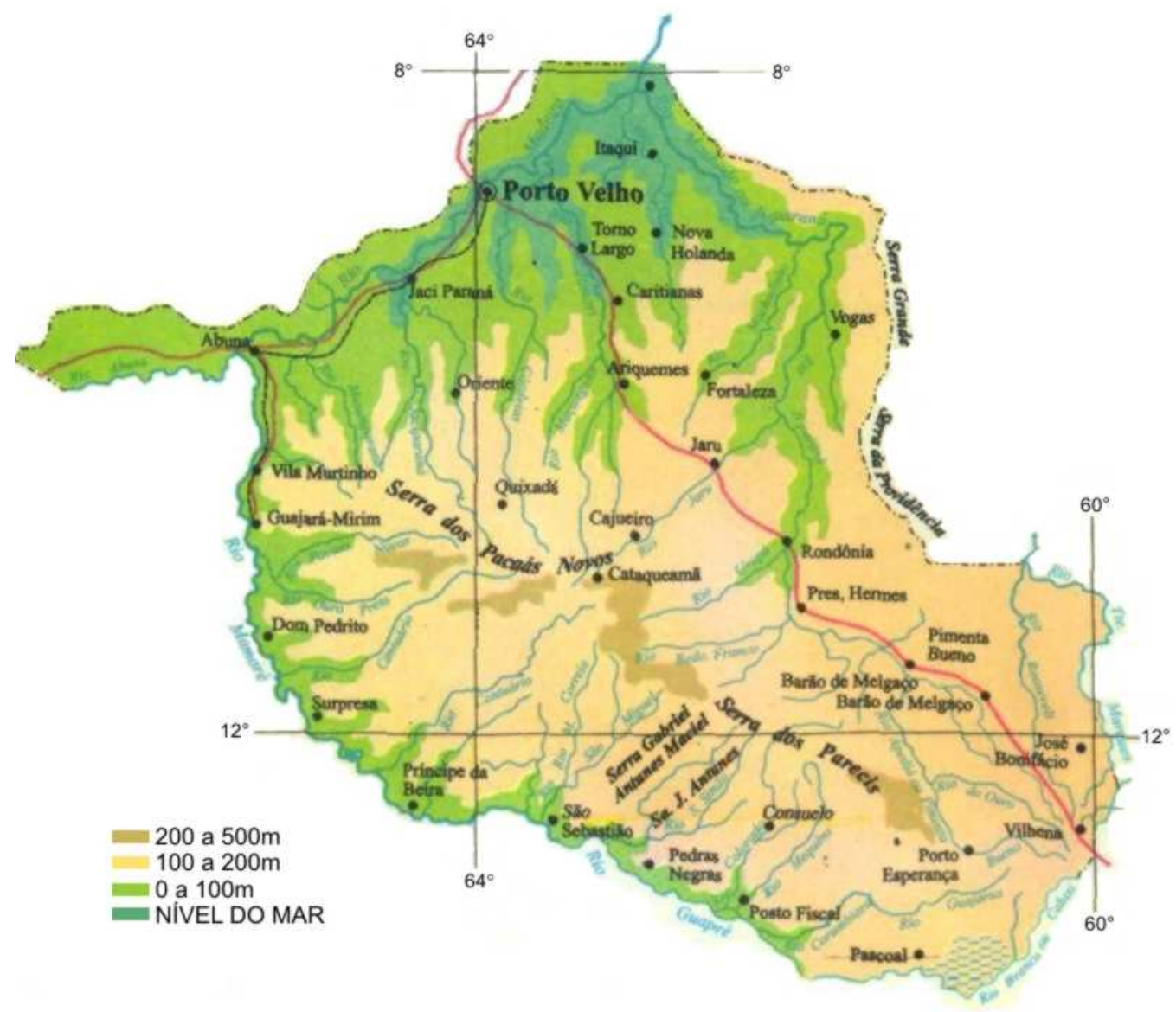

Imagem 4 - Altitudes no Estado de Rondônia, Fonte: Atlas do Estado de Rondônia, Editora Trieste (2002)

\subsubsection{Geologia}

No Estado de Rondônia compreende predominantemente litologias do Complexo Xingu e uma seqüência vulcanossedimentar com granitos intrusivos. $\mathrm{Na}$ área sudeste do Estado e no topo de alguns relevos com maiores altitudes encontra-se rochas sedimentares - arenitos - relacionados ao Paleozóico. Ao norte encontram-se sedimentos pliopleistocênicos da Formação Solimões.

De acordo com o Mapa Geológico do Estado de Rondônia (Scandolara et al.,1998), a área da bacia do rio Jiparaná compreende várias unidades litológicas. No rio Comemoração e na cabeceira do Pimenta Bueno observa-se um substrato sedimentar (arenitos, argilitos e siltitos), enquanto no setor mais à jusante deste último, podem ser observados afloramentos rochosos mais recentes (basaltos, gabros), dentro da Formação Basalto Anari. Na região 
central da bacia, os tributários Rolim de Moura e Jarú drenam rochas metamórficas (gnaisses, kinzigitos), enquanto no rio Urupá foi encontrada uma mistura de rochas de origem vulcânica e sedimentar. Os dois últimos afluentes mais importantes, Machadinho e Preto, apresentaram rochas sedimentares.

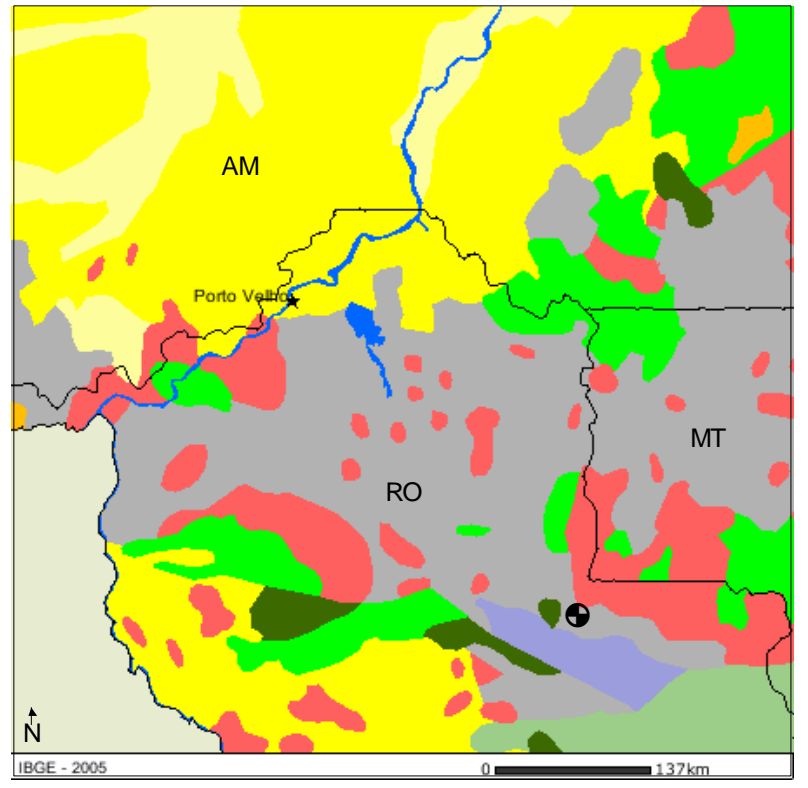

Sedimentos argilosos, arenosos e cascalhos

Sequências sedimentares e vulcanossedimentares de grau metamórfico baixo a médio

Sequências sedimentares, principalmente psamíticas, podendo incluir piroclásticas

Sedimentos arenosos do Pleistoceno

Sedimentos relativos a aluviões atuais e terraços mais antigos do Holoceno

Sedimentos argilosos, arenosos e cascalhos

Rochas gnássicas de origem magmática e/ou sedimentar de médio a alto grau metamórfico Associações de rochas de origem vulcânica e plutônica e composição félsica até máfica (posicionadas no final ou após o tectonismo)

Imagem 5: Geologia do Estado de Rondônia. Fonte: Ministério do Meio Ambiente, MMA, disponível na internet.

\subsubsection{Solos}

Os solos no Estado apresentam uma distribuição espacial bastante heterogênea. Os tipos de solos mais representativos são os Latossolos e Argissolos, seguido dos Neossolos, Nitossolos e Cambissolos. Existem áreas onde predominam solos mais arenosos, e manchas isoladas de solos com maiores teores de argila.( Imagem 6)

Para a bacia do rio Jiparaná, nas cabeceiras dos rios Pimenta Bueno e Comemoração, e em praticamente toda a área das sub-bacias dos rios Preto e Machadinho, encontram-se os solos mais pobres, ao passo que nas bacias dos rios Rolim de Moura, Urupá e Jarú localizam-se os solos mais ricos. Nas regiões centrais do Ji-Paraná e do Pimenta Bueno também são observadas manchas de solos mais ricos (Ballester et al. 2003). 


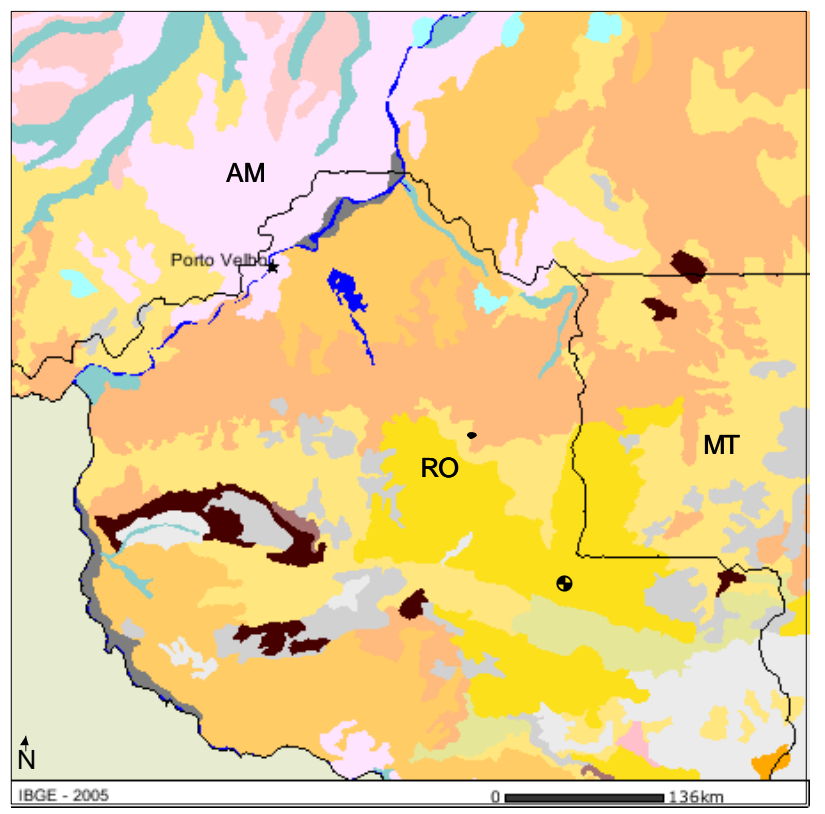

Argilossolo Vermelho-Amarelo

Sítio Encontro

Argilossolo Vermelho

Latossolo Vermelho-Amarelo

Latossolo Amarelo

Neossolo Quartzarênico

Neossolo Litólico

Neossolo Flúvico

Neossolo Flúvico

Afloramentos de Rochas

Nitossolo Vermelho

Alissolo Crômico

Gleissolo Háplico

Cambissolo Háplico

Imagem 6 - Solos do Estado de Rondônia, MMA

\subsubsection{Aspectos hidrográficos}

A drenagem do Estado pertence à bacia hidrográfica amazônica, afluente pela margem direita dos rios Solimões e Amazonas. Organiza-se geralmente em função do rio Madeira, que atravessa o sentido NE. Este é formado por três rios importantes: o Guaporé, o Mamoré e o Beni. O rio Guaporé tem suas nascentes nos contrafortes meridionais da Chapada dos Parecis e vem fazendo o limite natural com a Bolívia. Na cidade de Costa Marques-RO tem-se o conhecido Pantanal do Guaporé, uma área de florestas e campos inundáveis ao longo da fronteira entre o Brasil e a Bolívia com caracteristicas específicas. É zona de transição entre a Amazônia, o cerrado e o Pantanal Matogrossense. Em Guajará-Mirim recebe o rio Mamoré, passando a ter esse nome, até receber o rio Beni, ambos originários dos planaltos andinos. (RADAM,1978)

Em território rondoniense, os principais afluentes do Rio Madeira estão localizados em sua margem direita, sendo os rios: Castanho, Mutum-Paraná, Jaci-Paraná, Rio Jamari, e Rio Jiparaná. Na margem esquerda podemos apontar o Rio Abunã, o Rio Ferreiros e o Rio Aponiã. 
O Rio Jamari tem sua nascente no sudoeste da Serra dos Pacaás Novos, de onde corre, no sentido norte, desembocando na margem direita do rio Madeira. A região faz parte de uma extensa planície com raras e diminutas elevações.

O rio Jiparaná atravessa o estado de Rondônia de sudeste a noroeste. Sua bacia está localizada entre os paralelos 80.'S e 1259'S e os meridianos 600' 631' O. É formado pela confluência dos rios Pimenta Bueno e Comemoração, No seu médio curso, recebe os rios tributários Rolim de Moura, Urupá e Jarú. Mais à jusante recebe os afluentes rio Machadinho e Preto.

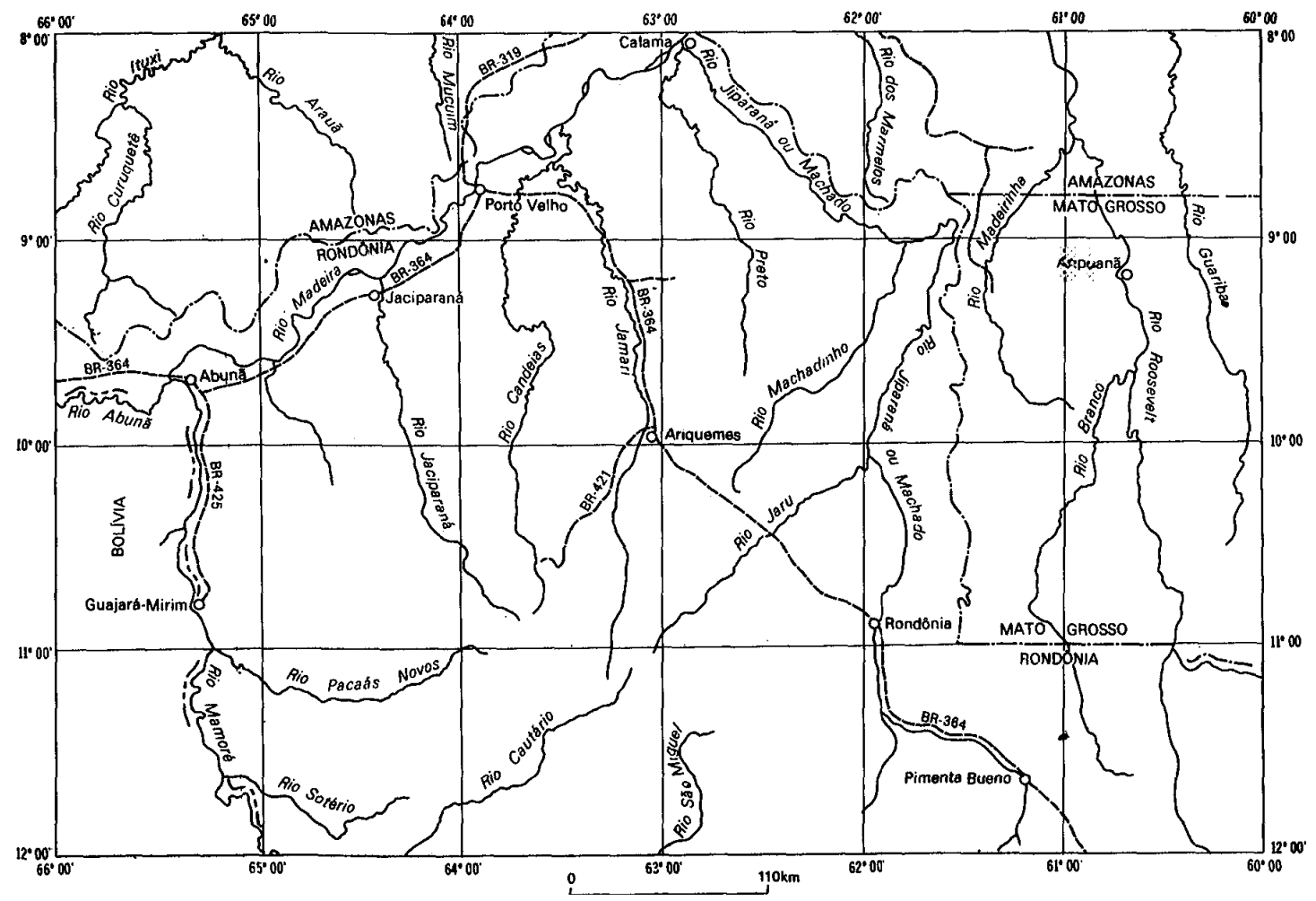

Imagem 7: Município, estradas e principais rios da região em estudo. Fonte: Projeto RADAM (1978).

\subsubsection{Vegetação}

O Estado de Rondônia possui vegetação variada, com predominância de Floresta. A Floresta Ombrófila Aberta - apresenta florestas de cipós, palmeiras e bambu - ocorre em quase todo o Estado. É interrompida pela Floresta Ombrófila Densa - constituída de palmeiras, trepadeiras lenhosas, epífitas e árvores de médio e grande porte - em locais de maior altitude. $\mathrm{Na}$ área nordeste e sudeste é interrompida pela a Floresta Estacional Semidecidual. 
Em meio à área florestal também ocorrem núcleos de vegetação de Savana, e na periferia ocorrem áreas de contato. Possui ainda áreas de vegetação de influência Fluvial.

Entre as cidades de Ji-Paraná e Vilhena, segundo ELETRONORTE (2002) são encontrados são encontrados os seguintes tipos de vegetação: Savana arbórea, Floresta Estacional Semidecidual Submontana, Floresta Ombrófila Aberta e Vegetação Secundária. Existem diversas áreas de contato entre a Savana e a Floresta Estacional, Savana e a Floresta Ombrófila e a Floresta Ombrófila e a Floresta Estacional. Praticamente toda área entre Ji-Paraná e Pimenta Bueno é caracterizada pela presença de Floresta Ombrófila e por uma vegetação secundária. Próximo a Vilhena, predomina a Floresta Estacional Semidecidual Submontana, seguida por áreas de Savana e áreas de contato entre ambas.

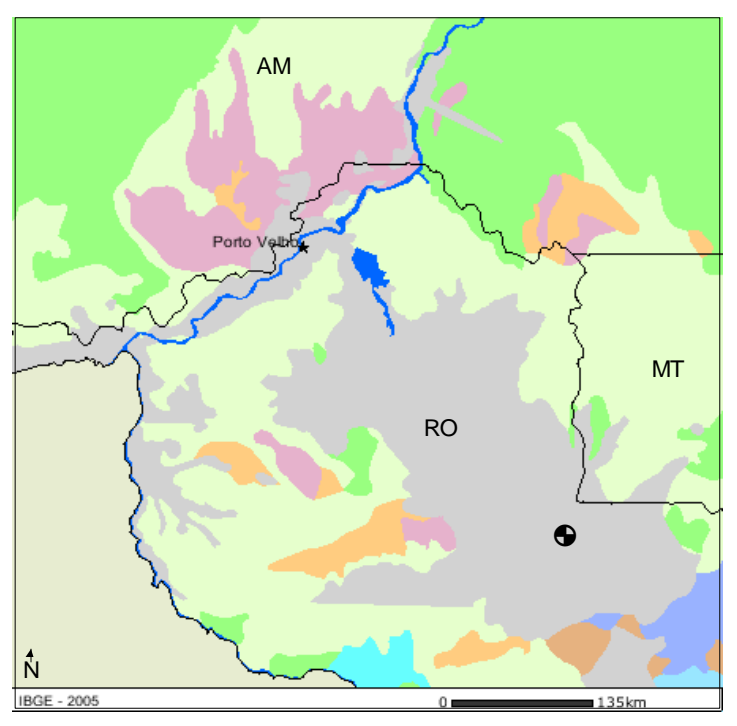

Imagem 8: Vegetação, fonte: MMA
Vegetação com Influência Fluvial ou Lacustr Savana / Floresta Estacional Floresta Ombrófila / Floresta Estacional Área Antropizada Floresta Estacional Semidecidual Savana Savana / Floresta Ombrófila Floresta Ombrófila Densa Floresta Ombrófila Aberta Sítio Encontro

\subsubsection{Clima}

A região se encontra na transição entre um clima quente e úmido e o quente semi-úmido, com estação no inverno. Segundo Koppen, pertence ao tipo Am, ao clima de floresta tropical com chuva do tipo monção. Caracteriza-se por elevadas precipitações cujo total compensa a estação seca, permitindo a existência de florestas. A temperatura média é de $24^{\circ} \mathrm{C}$. (Imagem 9) 

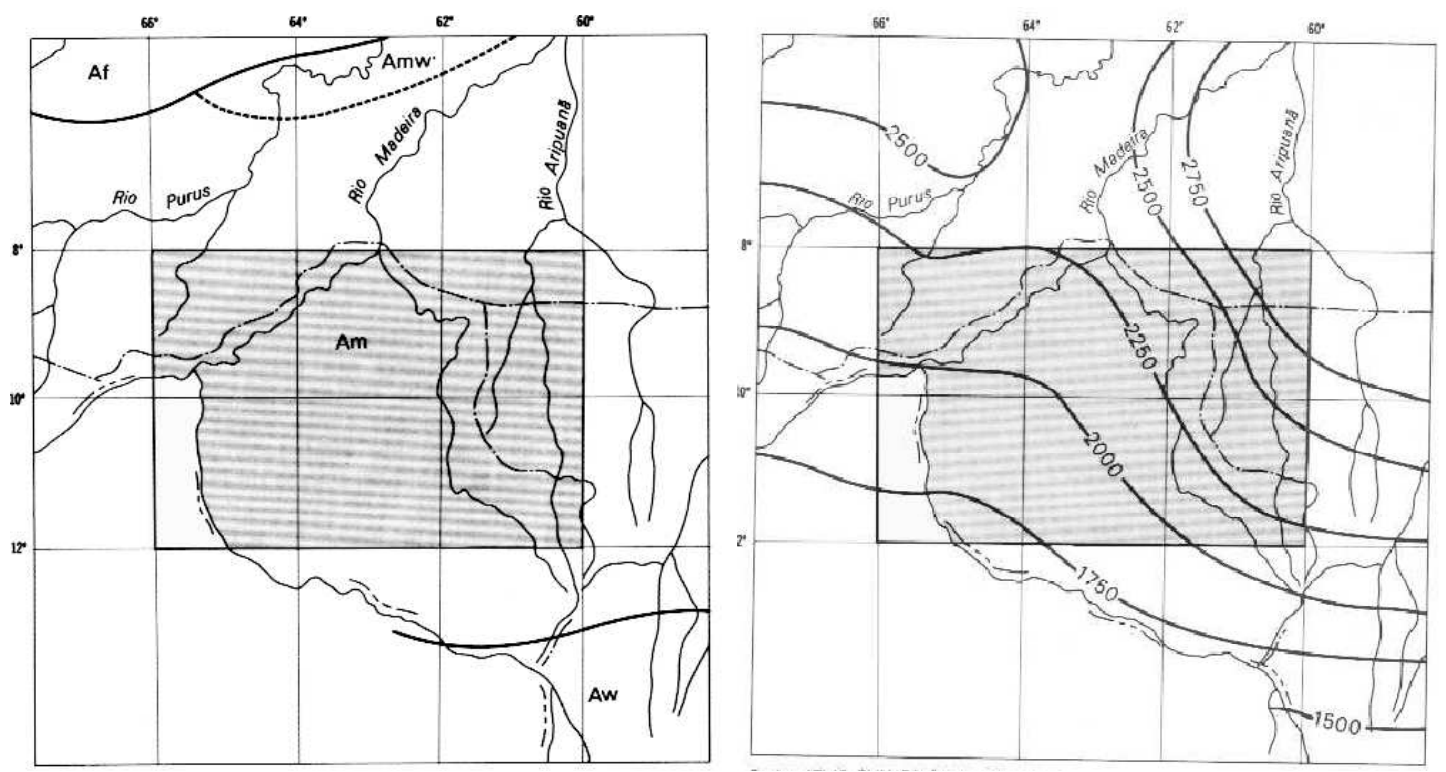

Imagem 9 - à esquerda a classificação do clima segundo Koppen, à direita os índices de precipitação anuais da área, expressado em mm/ano. Fonte: Projeto RADAM (1978), Carta SC.20-Porto Velho, p.259-260.

\subsection{Paleoambiente}

Hoje em dia a Amazônia possui um clima quente e úmido. No entanto, as pesquisas indicam que tal comportamento não fora constante durante os últimos 15.000 anos.

A partir de estudos palinológicos (Absy \& Van der Hammen, 1976; Absy, 1985; Behling e Hooghiemstra, 2000) isotópicos (Desjardins et al., 1996; Pessenda et al., 1996, Gouveia et al., 1999, Freitas et al., 2001) indicam a ocorrência de variações paleoclimáticas na Bacia Amazônica e em outras áreas do Brasil e da América do Sul, durante o Quaternário tardio. Paleoclimas mais secos que o atual, provavelmente, dominaram algumas áreas da Bacia Amazônica, favorecendo a substituição da floresta tropical por vegetação do tipo campo, entre 8.000-4.000 anos A.P., 4.200-3.500 anos A.P., 2.700-2.000 anos A.P. (Absy et al., 1991, Sifeddine et al., 1994, Gouveia et al., 1997, Pessenda et al., 1998, Freitas et al., 2001).

Estudos palinológicos em sedimentos de lagos da Serra dos Carajás (PA) indicaram que em períodos do final do Pleistoceno houve o desaparecimento e 
o surgimento parcial da floresta. O aparecimento dos campos, indicativo de períodos mais secos, ocorreu provavelmente entre 60.000-40.000 anos AP, 23.000-11.000 anos AP e 7.500-3.500 anos AP (Sifeddine et al., 1994).

Absy (1985) indica que durante parte do Holoceno - entre 5000 e 3000 anos AP - grandes áreas de savanas existiam na Amazônia, aonde atualmente existia floresta. Associado a este resfriamento, segundo o autor, ocorreram um abaixamento do nível dos mares, com consequências na quantidade de água na Bacia Amazônica. Diagramas de pólen indicam que também não havia floresta ao final do Pleistoceno (aproximadamente 11.500 anos passados). Entre 4000 e 2100 anos AP ), sugere que ocorreu grandes variações de precipitação na região Amazônica, causando o abaixamento (e em alguns casos secamento) de rios amazônicos, com mudanças significativas na fauna e flora.

Alguns estudos indicam que, apesar da presença de paleoclimas secos, em algumas regiões da Amazônia não foi verificado que o campo tenha substituído a vegetação florestal (Colinvaux et al., 1996, 2000; Pessenda et al., 1996, 1998b;Behling, 2001).

A substituição da floresta pela savana na bacia Amazônica durante os períodos da última glaciação tem sido um assunto controverso. Alguns pesquisadores sugerem que nesta região podem terem sido formados 'refúgios' de floresta, devido ao clima seco durante o Pleistoceno. (Haffer, 1969, Vanzolini, 1970, Brown e Ab' Saber, 1979).

De acordo com a teoria dos refúgios (Haffer, 1970, 1997; Vanzolini, 1970), floresta e savana mudaram constantemente durante o Pleistoceno se dividindo em locais isolados e se expandindo novamente combinado a variação de um clima seco para o úmido.

Dados sobre o nordeste boliviano, na divisa com os Estado brasileiros de Rondônia e Mato Grosso, apontam que praticamente durante os últimos 50.000 anos $\mathrm{AP}$, a baixa concentração de $\mathrm{CO}_{2}$ na atmosfera aliado a um longo período de seca, contribuiu para que a área fosse coberta por savanas e floresta secas sazonais, especialmente no último máximo glacial. Estes ecossistemas 
persistiram até o Holoceno médio. As florestas começam a se expandir entre 6000 e 3000 anos AP. Em 2000 anos AP a floresta densa úmida se expande por quase toda área. Burbridge et al.(2004)

No sul do estado do Amazonas, na divisa com o Estado de Rondônia, se encontram os denominados 'campos de Humaitá', formações de vegetação do tipo savana, que se transforma gradualmente em vegetação de floresta. Tais áreas estão presentes em toda a região e formam um sistema de vários campos circundados por vegetação de floresta. Os dados de isótopos de ${ }_{13} \mathrm{C}$ da matéria orgânica do solo ${ }^{5}$, em conjunto com as datações da fração humina do solo sugerem que, no final do Pleistoceno (há cerca de 17000 anos AP), o local estaria coberto predominantemente por floresta, indicando a ocorrência de clima úmido o bastante para manter esse tipo de vegetação na região. Há cerca de 9000-8000 anos AP houve expansão do campo e regressão da floresta possivelmente devido à presença de um clima mais seco e quente que o atual. Essa provável expansão das áreas de campo foi observada até cerca de 3000 anos AP. Deste momento em diante a floresta inicia uma expansão sobre os campos, sugerindo mudança para um clima mais úmido, semelhante ao atual. (Pessenda et al., 2001, Gouveia et al., 1996, Freitas et al., 2001)

Para Miller (1983) o paleoclima do sudoeste amazônico, de uma maneira geral, a partir de 40000 anos AP, apresenta períodos, que alternam desde semiáridos com savana a tropical com floretas úmidas, correspondentes respectivamente a clima glacial seco e interglacial úmido, até cerca de 13000 AP. a expansão e retração clima frio e semi-árido corresponderia a expansão / retração da floresta e savana. Um episódio de clima semi-árido poderia ter ocorrido entre 9000 e 7200 AP, aproximadamente. A partir de 6000-5500 AP teria ocorrido o inicio do optimum climaticum; desde então apenas fases poucos pronunciadas e de curta duração de seca teriam ocorrido depois de 3500 AP e entre 1950 e 1500 AP. Desde então seria o clima atual com ligeiras modificações.

\footnotetext{
${ }^{5}$ Mais informações sobre os isótopos estáveis de C12 e C13, no item Estratigrafia e cronologia, no capitulo 3.
} 
Para Adams e Faure (1998) o clima seria mais constante nos últimos 5000 anos. No inicio do holoceno existiam zonas de transição floresta-cerradosavana na maioria da Amazônia e a savana ocupava a porção sul. (FIG 10,000 anos) No final do pleisceno 14000 anos ap é provável que a zona de transição foi ocupada principalmente por savana. Esta seqüência de 10000, entre 14000 a 5000 anos AP é provavelmente um período critico para as primeiras domesticações de espécies nativas da Amazônia.(Clement, 2001) 


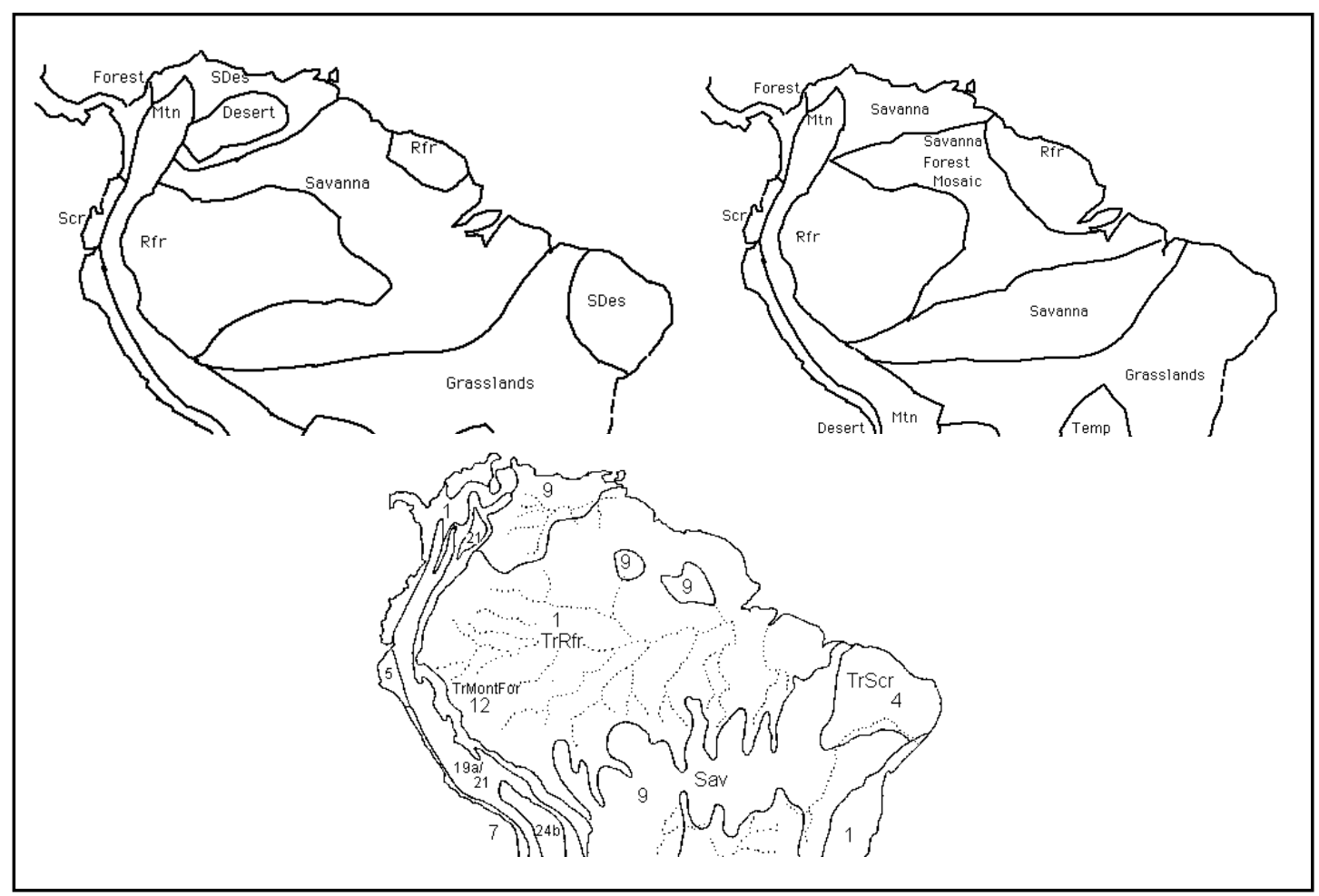

Imagem 10: três cenários propostos por Adams e Faure (1998), a partir dos dados do .... para a vegetação nos últimos 14000 anos, acima a esquerda, 14000 anos AP, e a direta 10000 anos AP, abaixo entre 8000-5000 anos AP. 


\section{CAPÍTULO 2 - ARQUEOLOGIA EM RONDÔNIA}

(...) Pela porteira da frente, onde se chegam e se vão,
os olhos destes campeiros se perderam na amplidão,
confundindo os velhos rastros, com as cicatrizes do chão,
Vai que tu tá livre(...)

Gujo Texeira

Todos os dados disponíveis para o Estado de Rondônia foram produzidos pelo arqueólogo Eurico Theófilo Miller. ${ }^{6} \mathrm{Em}$ mais de vinte anos de pesquisa, percorrendo milhares de quilômetros, consegue estabelecer e organizar os primeiros dados arqueológicos, situados na bacia do rio Madeira, no Pantanal do Guaporé, no Rio Guaporé, na bacia do rio Jamari e Jiparaná. Dentro de suas publicações (Miller,1983,1987a, 1987b, 1992, 1999, Miller et al. 1992, Miller e Caldarelli, 1987, Miller e Meggers, 2003) o pesquisador cria diversas fases líticas, uma tradição e uma subtradição cerâmica, além de outras fases cerâmicas sem cronologia e tradição arqueológica definidas. (Imagem 11)

\subsection{Primeiros IndícIOS - OS ANTIGoS SítIOS Líticos e A CERÂMICA INCIPIENTE}

A mais antiga ocupação para o estado de Rondônia é apontada por Miller e Meggers (2003) que citam a datação de 13500 AP para um sítio pré-cerâmico localizado no rio Jiparaná. Em uma área do estado do Mato Grosso, divisa com Rondônia, no rio Guaporé, Miller (1983) identifica o Complexo pré-cerâmico Dourado. Em um sítio deste complexo, denominado Abrigo do Sol, o autor traz a datação de 14700 195 AP. Apesar de ser bastante recuada, e não ser muito bem aceita, outras amostras indicam para este sítio horizontes de paleossolo com datações entre 10400 e 12300 anos AP $^{7}$.

\footnotetext{
7 Sítio MT-GU-01, Abrigo do Sol, entre $520-560 \mathrm{~cm}$, artefatos líticos em paleossolo com datação entre $10405 \pm 100$ a.P (SI-3476) e $12300 \pm 95$ a.P. (SI-3477) (Miller, 1983)
} 
Imagem 11: Tradições, Fases e Sítios Arqueológicos no Estado de Rondônia 
Outros sítios com datas mais recuadas cronologicamente e relacionados ao holoceno antigo são encontrados no rio Jamari. Este rio tem sua nascente no sudoeste da Serra dos Pacaás Novos, de onde corre, no sentido norte, desembocando na margem direita do rio Madeira. A região faz parte de uma extensa planície com raras elevações.

Ao longo de seu baixo e médio curso, as datações estabeleceram uma ocupação de pelo menos 8000 anos. Em Miller et. alli,.(1992) encontramos as três Fases líticas (sem tradição definida) que compreendem a fase inicial de ocupação do local.

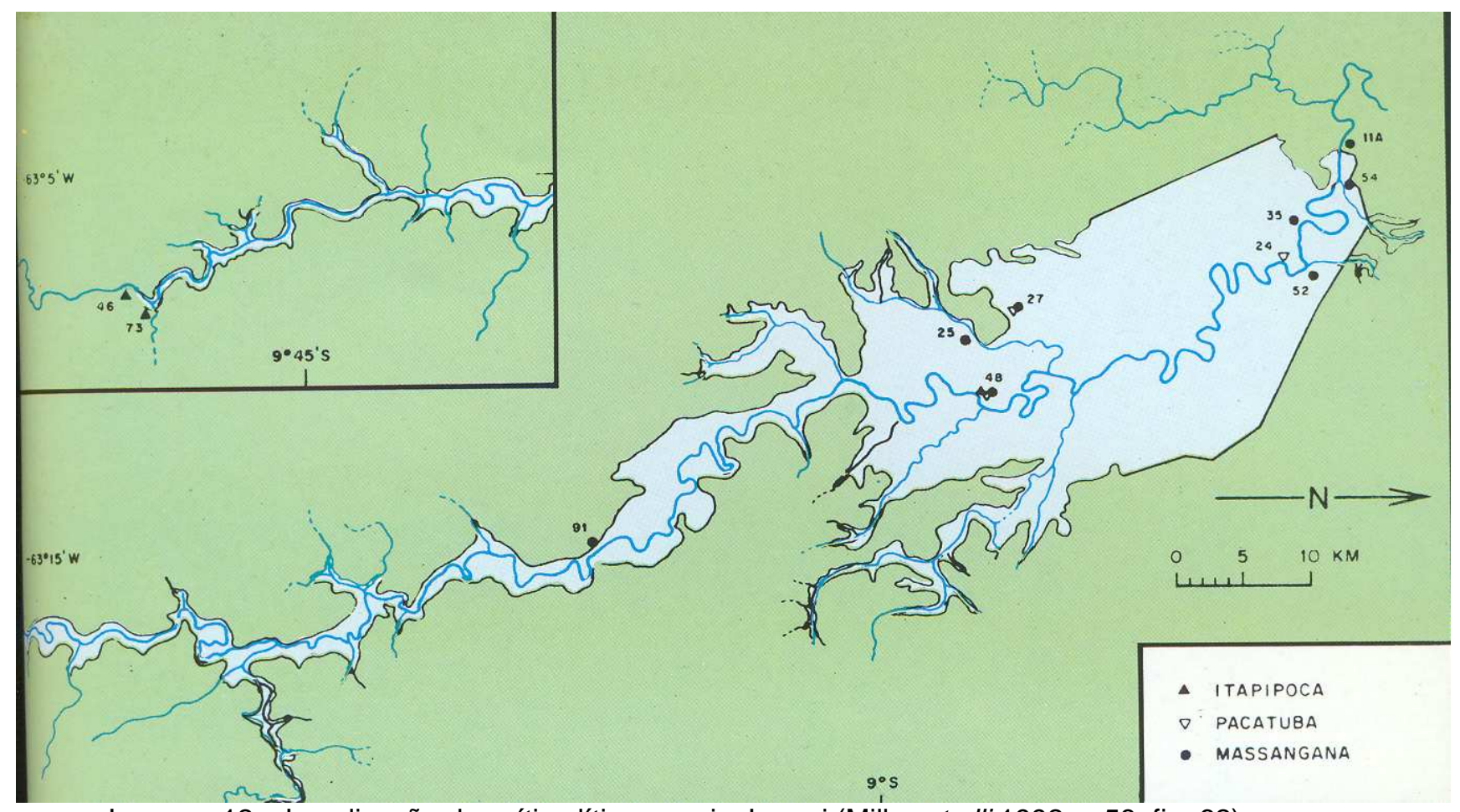

Imagem 12 - Localização dos sítios líticos no rio Jamari.(Miller et alli 1992, p.58, fig. 62)

\section{Fase Itapipoca}

$8320 \pm 100-6970 \pm 60-$ Miller et alli (1992)

São sítios-acampamento sobre barrancos do rio Jamari. Dois deles com uma camada cultural fina, de $15 \mathrm{~cm}$ de espessura, logo acima do granito. Outro mais espesso, com uma camada de $90 \mathrm{~cm}$, entre $510-600 \mathrm{~cm}$ de profundidade.

Indústria lítica é composta por lascas, percutores, raspadores laterais e terminais, percutores com evidências de uso e núcleos esgotados, produzidos 
em calcedônia, quartzo, rochas cristalinas e basalto. Quatro datas em RO-PV48 vão de $8320 \pm 100$ (Beta-27015) - 6970 \pm 60 (Beta-27013).

\section{Fase Pacatuba}

$6090 \pm 10-5210 \pm 70$ - Miller et alli (1992)

Sítios-acampamento sobre barrancos altos do rio, abaixo dos sítios-habitação da Fase cerâmica Jamari, com camadas culturais de 40 a $310 \mathrm{~cm}$ de espessura, de 0,9 e $2 \mathrm{~m}$ a 1,3 e 5,1m abaixo da superfície atual.

Em sua indústria lítica encontram-se lascas, percutores em seixos, em quartzito e sílex, pedras-bigorna, núcleos, e no final da seqüência, polidores, toscas lâminas de machado lascadas bifacialmente, microlascas em quartzo e lajotas com depressões picoteadas. Quatro datas dos sítios RO-PV-35 e RO-PV-48 estendem-se de $5210 \pm 70$ AP (Beta-27017) a 6090 \pm 130 AP (Beta-27658).

\section{Fase Massanganá $4780 \pm 90$}

$2640 \pm 60$ AP Miller et alli (1992)

A fase Massanganá, datada em 4780 AP, com duração de aproximadamente 2000 anos surgiria em pleno Ótimo Climático. Nesta fase é que ocorrem as terras pretas arqueológicas mais antigas da Amazônia. O Padrão de assentamento desta fase pré-cerâmica consiste em Sítios-habitação sobre barrancos altos, na terra firme, adjacentes ao rio e afluente, o rio Massangana, abaixo dos sítios-habitação da Fase Jamari e acima dos sítios-acampamento da Fase Pacatuba (Miller et alli 1992).

Os artefatos líticos da fase correspondem a microlascas principalmente de quartzo, algumas com evidências de uso, raros raspadores pequenos. Pedrasbigorna, pequenos pilões e pequenas mãos de pilão. Núcleos, percutores, moedores impregnados de corante e pedras corantes (hematita). Raras lâminas-de-machado picotadas, lascadas, mal-alisadas e pequenas. As matérias primas escolhidas foram principalmente rochas cristalinas, com menor freqüência de calcedônia, quartzo e laterita. 
As terras pretas evidenciadas variaram em camadas de 45 a $80 \mathrm{~cm}$ de espessura, enterradas entre um e dois metros da superfície atual. Trincheiras escavadas no sítio RO-PV-48 expuseram horizontes de até 180×90m. Dezenove datas em seis sítios situam a fase entre $4780 \pm 90$ e $2640 \pm 60$ AP.(Miller et alli 1992, 1992)

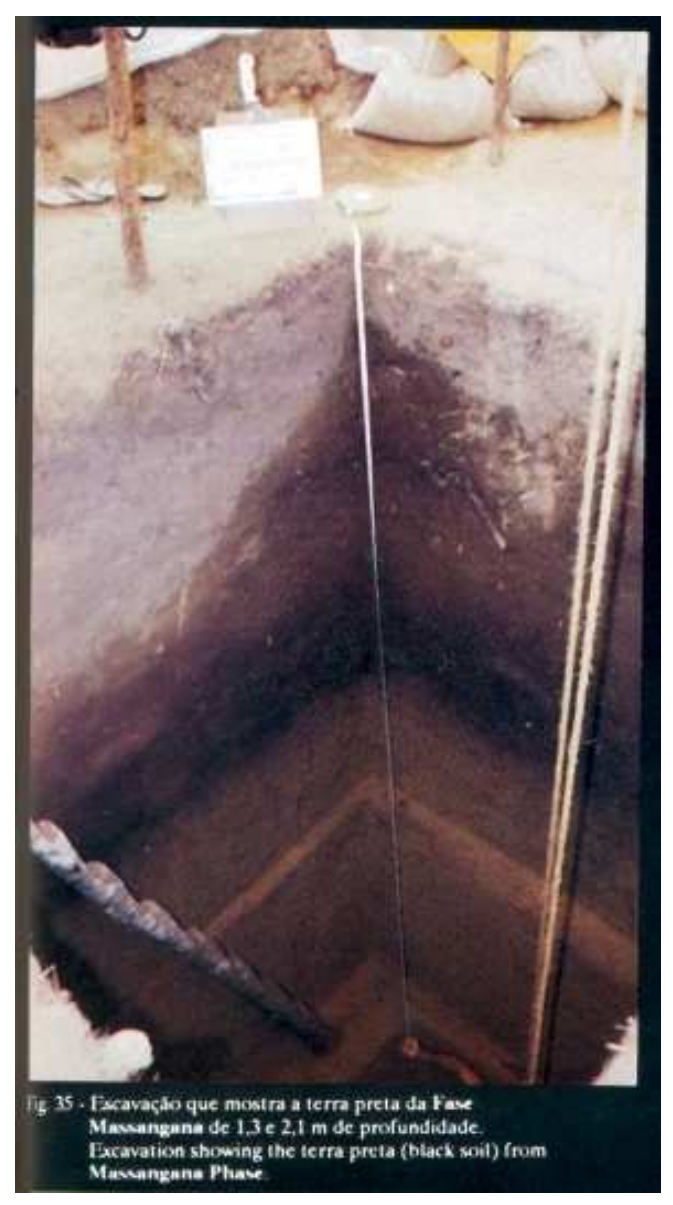

Imagem 13 - Sítio da fase Massangana, Fonte: Miller et alli (1992). 
IMAGEM 14 - MATERIAL LITICO DO RIO Jamari Miller etalli 1992 
No Pantanal do Guaporé Miller (1999) identifica uma Tradição lítica e uma Fase cerâmica, sem tradição estabelecida.

\section{Tradicao sinimbu}

Segundo Miller (1992), trata-se de uma Tradição pré-ceramista, construtora de sambaquis, ocupa a área por cerca de 2000 anos, precedida por uma fase préSinimbu, pouco conhecida, desde início do Ótimo Climático e da formação do Pantanal do Guaporé - especulativamente, cerca de 7500 AP - quando a caça, evidenciada por ossos mineralizados abaixo das conchas do sambaqui, ainda era bem menos escassa que os moluscos. Para o surgimento dos sambaquis é relacionado com a abundância e a possível preferência por moluscos. O Sítio RO-PN-08 chega a $80 \times 60 \times 4,2 m$. Na indústria lítica aparecem pontas-deprojétil. Foi obtida uma datação de 6315£105 AP (SI-6850).

\section{Fase Bacabal}

Nas camadas mais recentes destes assentamentos são encontrados os primeiros vestígios cerâmicos, atribuídos a Fase Bacabal. Esta fase

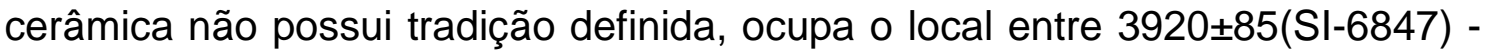

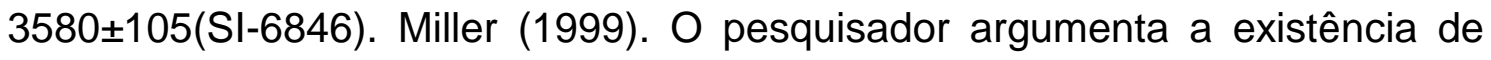
uma descontinuidade climática (úmido-seco-úmido) entre 4395 470 AP (SI6747) e 3920 \pm 85 AP(SI-6847) (final do ótimo climático) demarcada por uma camada de solo com $10-15 \mathrm{~cm}$ de espessura (entre $220-235 \mathrm{~cm}$ de profundidade), onde ocorreram algumas conchas e evidências culturais intrusivas devido a buracos de estaca em dois sambaquis. No solo do pantanal o término dessa descontinuidade climática, de seco para úmido, está representada por uma fina camada $(1-3 \mathrm{~cm})$, com carbonato de ferro, na qual se incrustam os testemunhos cerâmicos mais antigos, tendo furos, rebaixos e vãos de decoração plástica preenchidos por concreções. 


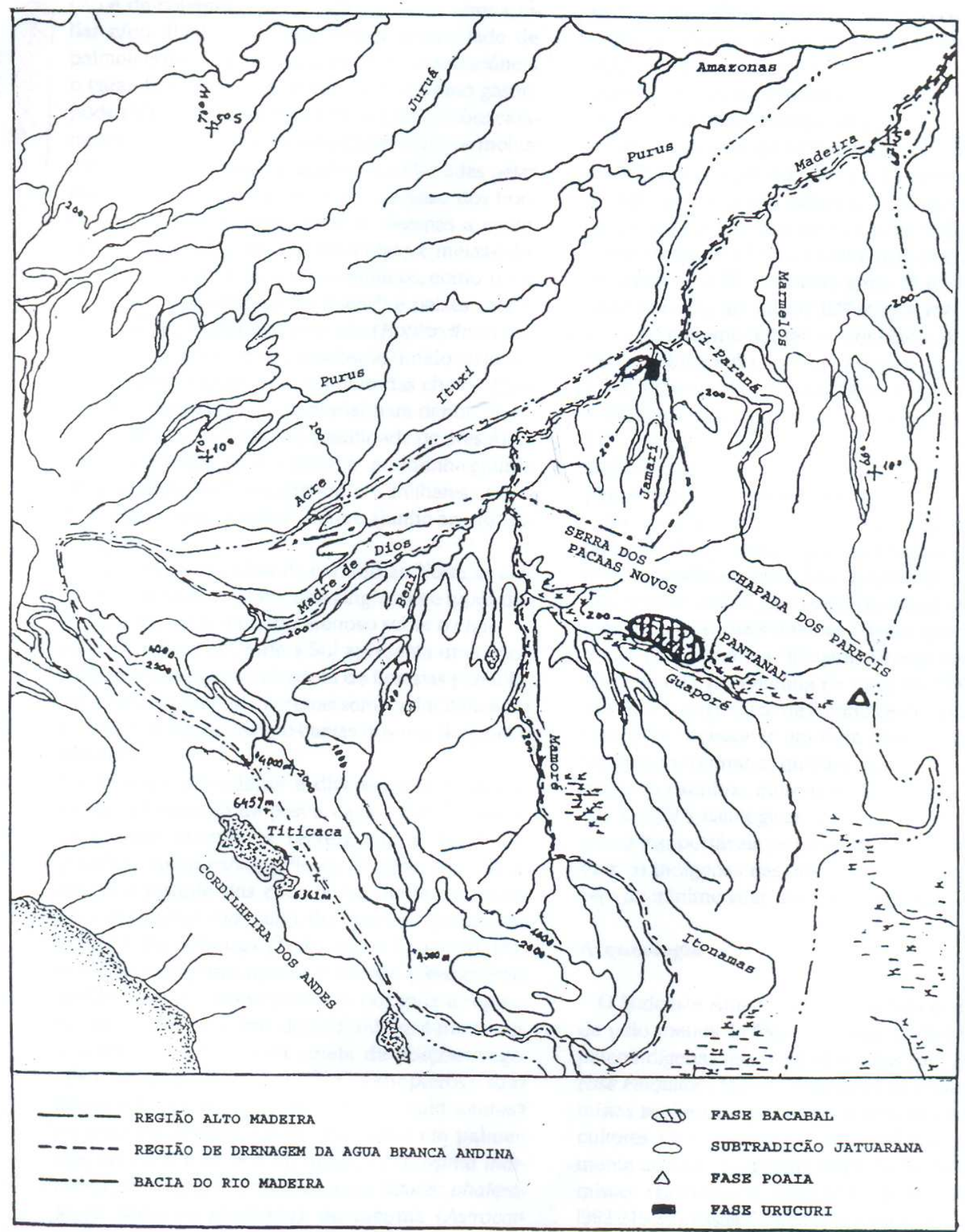

Imagem 15 - Fases cerâmicas do sudoeste amazônico. Fonte: Miller (1999)

Para o autor a fase cerâmica surge já desenvolvida, com padrões de assentamento em sambaqui, estes construídos por povos portadores da 
Tradição Sinimbu ${ }^{8}$. Possuindo um numero maior de sítios, em relação à Tradição Sinimbu, era possivelmente semi-sedentária. Segue afirmando que os grupos exploraram intensamente e extensamente a proteína de moluscos gastrópodes lacustres, alguns terrestres. A prática de agricultura, consumo da tabua e/ou arroz selvagem, são sugeridos pelo vasilhame cerâmico, mós e almofarizes. O fumo, ou algo similar, pelos cachimbos cerâmicos. A pesca, é evidenciada pelos anzóis conchíferos e restos ósseos, e a caça, pelas pontasde-projétil, iguais as da Tradição Sinimbu.(idem)

Em relação a cerâmica, Miller (1992), argumenta que o periperiaçu ${ }^{10}$ e a tabua foram empregados na cestaria, sugerido segundo moldes negativos nas bases dos vasilhames. As bases dos vasilhames são plano-circulares e as bordas são elipsóides, com extremos elevados, portando asas simples e bastante elaboradas e estilizadas, as vezes zoomórfas e raramente antropomorfas. Entre os tipos decorados o engobo vermelho, o exciso, e o inciso foram os mais empregados.

Sobre o padrão de assentamento é entendido que casas eram construídas sobre os sambaquis da Tradição Sinimbu. Haviam enterramentos no sambaqui. Os mortos eram colocados na posição dorsal distendida, com diferentes oferendas, de cerâmica: tigelas, cachimbos; lítico: lâminas-de-machado, mãosde-pilão, almofarizes, mós, e de concha e osso: adornos de valvas perfuradas e túbulos. As áreas de evidência cerâmica extrapolam o sambaqui (que são subcirculares desde $8 \times 10 \mathrm{~m}$ até $105 \times 145 \mathrm{~m}$, quatro quintos do sambaqui inteiro) expandindo-se em direção às depressões flúvio-lacustres. (Miller, 1992 e 1999)

Os primeiros indícios cerâmico ocorridos no Estado, atribuídos a fase Bacabal (Miller, 1992 e 1999), podem estar ligados a um fato que começa a ficar recorrente na história da Amazônia: as primeiras manifestações cerâmicas estão relacionadas a grupos especializados na obtenção de recursos

\footnotetext{
${ }^{9}$ Grande erva, até $3 \mathrm{~m}$, da família das tifáceas (Typha domingensis), que vive em águas paradas e rasas, pois radica-se no fundo lamacento por meio de um rizoma, que é comestível. As folhas servem para tecer esteiras e cestos.

${ }^{10}$ Conhecido também como papiro.
} 
aquáticos, tanto nos rios, quanto na várzea (sítio Taperinha, Roosevelt, no Baixo Amazonas, Sambaquis Perotta no alto Xingu), como na costa atlântica, (Sambaquis da tradição Mina, Simões, 1981).

Existe em Rondônia uma carência de dados cerâmicos entre os períodos de $3580 \pm 105$ (final da fase Bacabal) e 2730 \pm 75 (início da Subtradição Jatuarana). Para este período, existem evidencias de ocupação atribuídas a fase lítica Massangana, na bacia do rio Jamari.

\title{
2.2 O ESPRAIO DAS EVIDÊNCIAS CERÂMICAS
}

Subtradição Jatuarana $2730 \pm 75$ - $2340 \pm 90$ AP - Miller $(1987 a, 1987 b$, 1992, 1999)

Miller (1987) cria a subtradição ceramista Jatuarana e a atribui a Tradição Polícroma. No mesmo ano, Miller(1987b) constata que esta subtradição teria características semelhantes a fase Guarita, da Amazonia central.

\begin{abstract}
(...)esta cultura é conhecida como complexo por só apresentar características comuns à subtradição Guarita,(...) no final da sequencia seriada(mediana-superior)(só na seriada, estratigraficamente tem diferença ou nao) mais recente onde a policromia é mais popular que a decoração plástica. Da porção mediana da seriação para a base da mesma, a decoração plástica se torna mais popular que a policromia(...) Miller(1987b) p.17
\end{abstract}

É caracterizada a partir de 32 sítios-habitação que ocuparam as margens do médio Madeira e do baixo alto-Madeira numa extensão aproximada de $550 \mathrm{~km}$, desde a confluência do rio Marmelos a juzante, até as primeiras cachoeiras e corredeiras a montante. O Modelo de ocupação territorial tem o alto Madeira como eixo principal, com sítios-habitação ocasionalmente até $900 \mathrm{~m}$ do dique marginal, e como eixo secundário, lagos como o Cuniã com extensas várzeas inundáveis. A região faz parte da Planície Amazônica com apenas algumas pequenas e suaves elevações rochosas junto as cachoeiras. (Miller, 1999) 


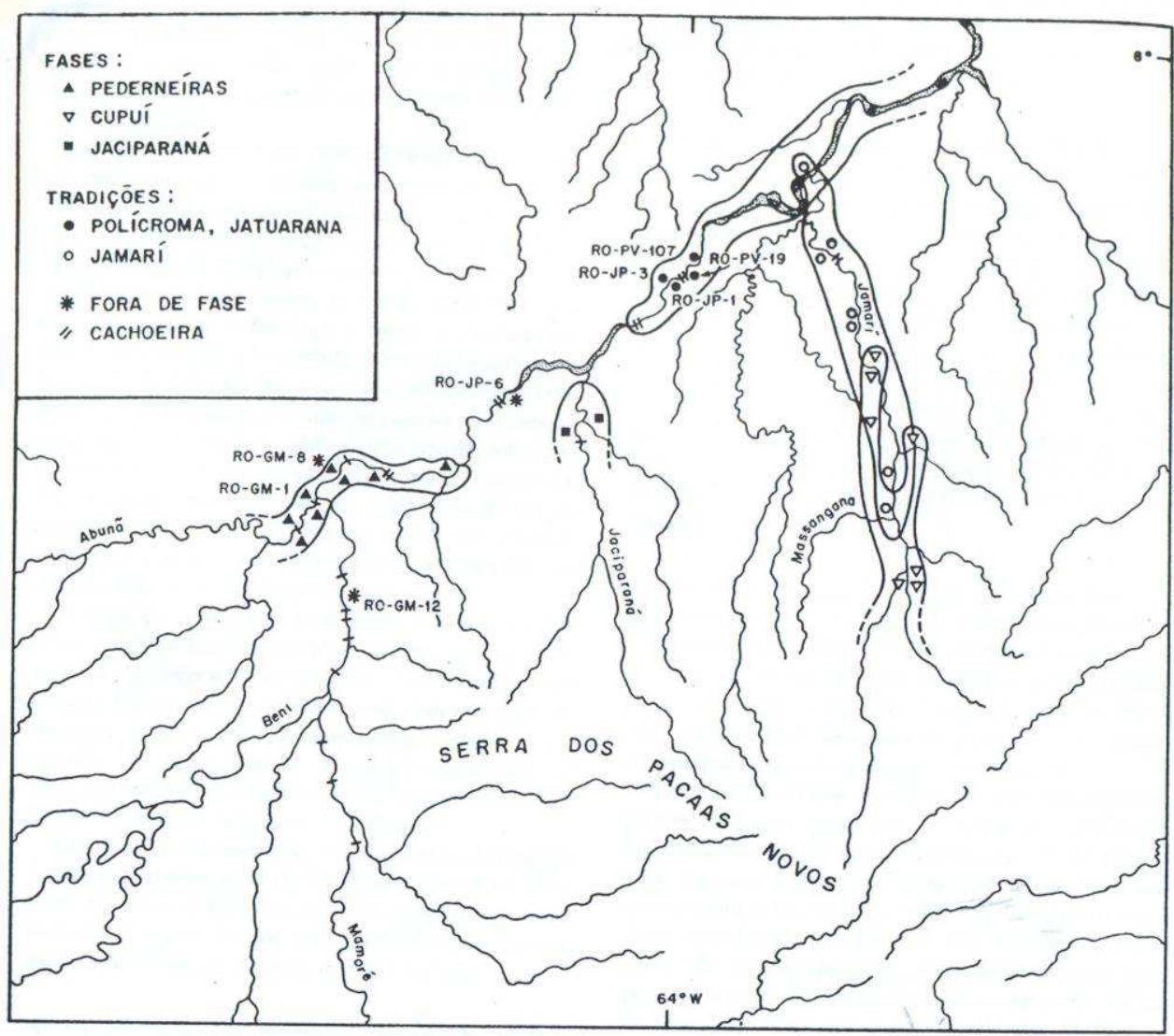

Imagem 16: Localização dos sítios, por fases arqueológicas, no alto rio Madeira. (Miller, 1992, p.226)

A cerâmica apresenta uma pasta levemente arenosa, com tempero de: cariapé e carvão, cariapé, cariapé e cauxí e cauxi. A simetria é quase perfeita, a espessura é fina a mediana e regular, a pasta é compacta porosa e leve, o tratamento de superfície é bem elaborado e esmerado, desde o alisado ao polido, brunhido e envernizado (resina de jatobá). (idem)

A decoração plástica consiste em técnicas de exciso raspado, inciso dupla linha e outros, ponteado, ponteado arrastado, ungulado, pinçado, serrungulado, serrilhado fino, estampado, carimbado, que ocorriam isolados e combinados entre si, com ou sem engobo, monocromia, policromia, associados ou não a apliques zoomórficos, antropomórficos, flanges, alças, asas e outros artifícios. A decoração crômica afora o engobo vermelho, compreende monocromias sobre superfície simples em positivo ou negativo, policromias sobre engobo branco ou não, com as cores preta, marrom, magenta, vermelho, laranja, 
amarelo e creme, combinadas, misturadas e associadas ou não com decoração plástica. A decoração apresenta motivos em linhas, faixas e campos curvilíneos, geométricos, zoomórficos e antropomórficos combinados entre si. Os tipos retocados compreendem o inciso, exciso raspado e acanalado fino, retocados ou preenchidos com branco, amarelo, laranja e vermelho.

Em relação a morfologia dos vasilhames é apontado que variam de tigelas de planta tanto simples circular como complexamente curvilíneas, rasas a profundas, contorno simples a composto, entre 10 e $36 \mathrm{~cm}$ de diâmetro,com bordas introvertidas, diretas, extrovertidas e dobradas tipo prato, podendo apresentar-se acasteladas ou complexamente recortadas; raros assadores de beiju, de 30 a $45 \mathrm{~cm}$ de diâmetro, vasos rasos e profundos de planta circular, simples, globulares, hemisféricos, cilíndricos, carenados e compostos, de 9 a $56 \mathrm{~cm}$ de diâmetro; bordas expandidas e introvertidas a verticais, diretas e extrovertidas, lábios arredondados, planos, apontados e mistos, bases plana, arredondada, anelar e pedestal. Contas vazadas e arredondadas, torneadores sobre cacos com canaletas em meia-cana, com 2 a $5 \mathrm{~mm}$ de profundidade e 4 a $8 \mathrm{~mm}$ de largura. "Porta-vaso" com pedestal bicônico, pesos-de-fuso arredondados de caco de cerâmica.

Ainda foram identificados enterramentos, secundários, em urnas antropomórficas de até $69 \mathrm{~cm}$ de altura, com pescoço leve a fortemente conscrito localizados em sítios-cemitério afastados dos sítios-habitação(Miller, 1992).

O material lítico engloba lâminas-de-machado, simétricas e polidas, de formas variadas Foi evidenciado também material em resina, sendo adornos cilíndricos, retos, alongados e maciços, finamente polidos, com diâmetros de 6 a $8 \mathrm{~mm}$, comprimento entre 58 e $76 \mathrm{~mm}$. 


\section{Tradição Jamari}

Miller (1992 e 1999)

Esta tradição ceramista foi localizada ao longo do médio e baixo rio Jamari. Os 96 sítios lito-cerâmicos ocuparam o baixo Jamari e baixo curso de seus afluentes, ao longo de aproximadamente $340 \mathrm{~km}$, desde o seu coletor, o rio Madeira pela margem direita até seu tributário pela margem esquerda, o rio Massangana.

Os traços diagnósticos desta Tradição Cerâmica são o antiplástico de cariapé e de areia, e a rara decoração composta principalmente de banho vermelho. (Miller et alli 1992,Miller 1992 e 1999). Quarenta e duas datas em quatorze

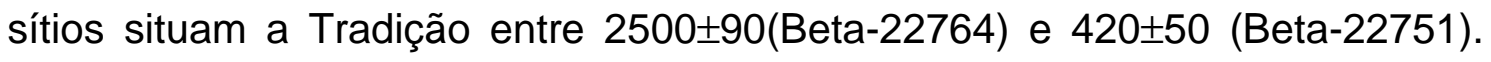
Está subdividida em 4 fases cerâmicas: Urucuri, Jamari, Cupuí e Matapi 


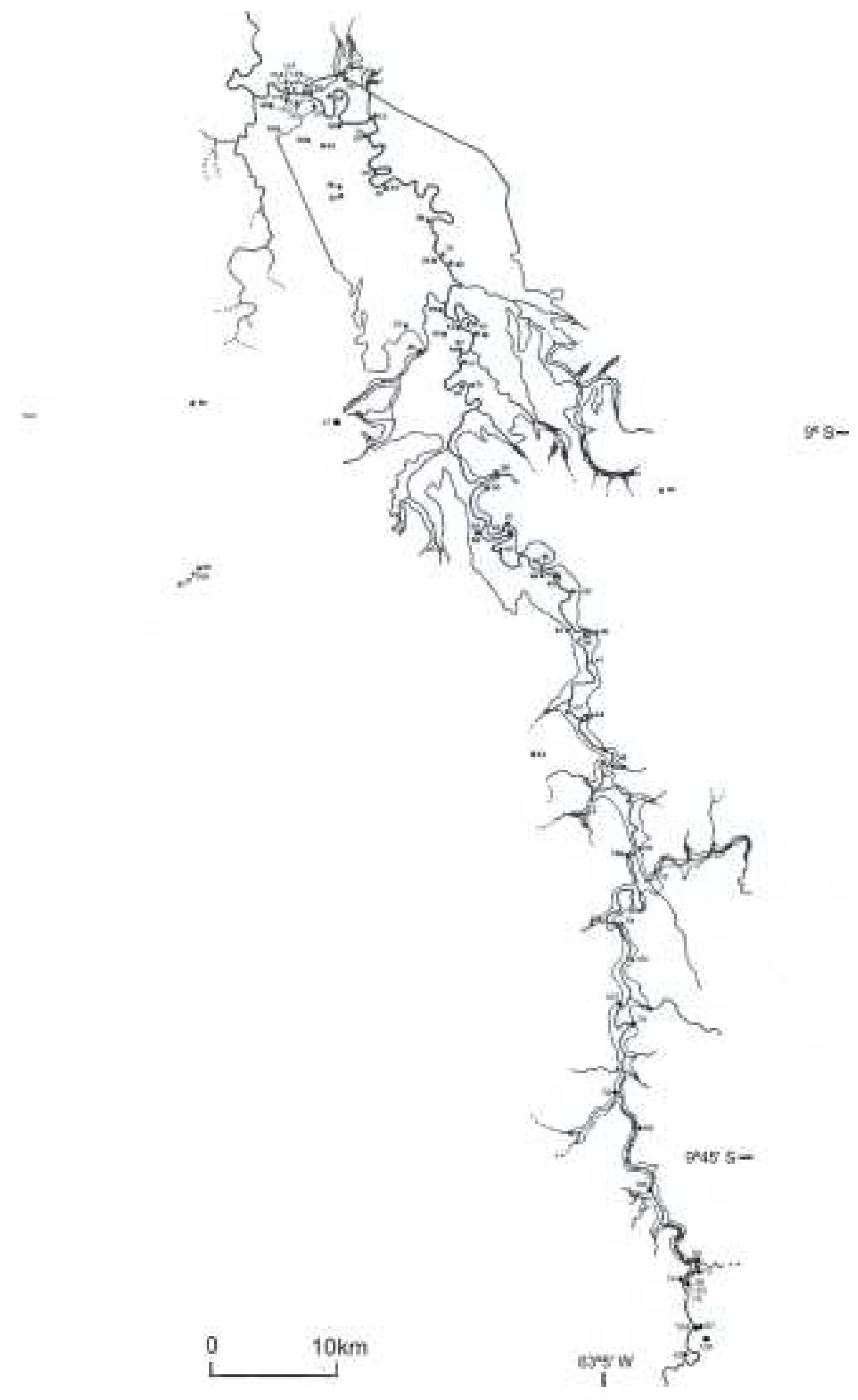

Imagem 17: localização dos sítios cerâmicos no rio Jamari. Fonte: Miller et al. (1992), p. 33. 
Fase Urucuri 2500 $\pm 90-2230 \pm 50$ Miller et alli, 1992

Trata-se de sítios-habitação sobre altos barrancos, próximos ao rio, demarcados com manchas de Terra Preta circulares, de 80 a $300 \mathrm{~m}$ de

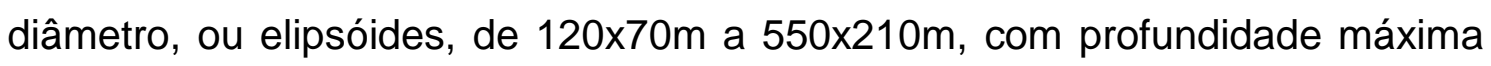
de $90 \mathrm{~cm}$. Sobrepõem-se sobre os sítios da fase Massangana.

Características gerais da cerâmica são: o antiplástico com areia ou cariapé (rara intrusivamente cauixi), a manufatura por acoradelado, a decoração de banho de engobo vermelho, e raramente a pintura e o inciso. Estas incisões seriam finas ou largas com motivo linear e geométrico simples.

A morfologia dos vasilhames compreende tigelas rasas e profundas, vasos hemisféricos a globulares, bordas diretas, introvertidas e extrovertidas, lábios arredondados, apontados ou planos.

O material lítico da fase corresponde a lâminas-de-machado, pequenas, polidas, picoteadas/lascadas, percutores, almofarizes, moedores, pequenas mãos-de-pilão e pedras corante (hematita).

Dez datas de 7 sítios estendem-se de 2500 \pm 90 (Beta-22750) - 2230 \pm 50 (Beta 32324) Sub Fase A $2410 \pm 50$ (Beta-22757) a $2230 \pm 50$ (Beta-32324). Subfase B $2500 \pm 90$ (Beta 22750) até 2280 \pm 100 (Beta-22744)

\section{Fase Jamari $2130 \pm 140-420 \pm 50$ Miller et alli, 1992}

Trata-se de sítios-habitação, sítios-acampamento e sítios-oficina, por vezes associados uns aos outros. São elipsóides com dimensão horizontal de 190x120m a $550 \times 210 \mathrm{~m}$, circulares de 80 a $300 \mathrm{~m}$ de diâmetro, demarcados pela Terra Preta. A profundidade máxima é de 0 a $90 \mathrm{~cm}$. Frequentemente encobre níveis da fase Urucurí, e por vezes sobrepõe-se a ocupações da Fase Massangana.

As principais características da cerâmica são: um Antiplástico com cariapé ou com areia, raramente cauxi, cauxi e cariapé; manufatura por acordelado; 
Imagem 18 
Imagem 19 
decoração principalmente com engobo vermelho, inciso e pintado, muito raramente com inciso largo, ponteado, serrungulado, roletado, modelado e escovado. As superfícies são regularmente alisadas.

As formas dos vasilhames são de tigelas rasas e fundas, vasos hemisféricos a globulares, bordas diretas, introvertidas e extrovertidas, lábios arredondados, apontados ou planos. Raríssimas formas de tigelas geminas, bivalves, bordas lobuladas.

O material lítico característico da fase corresponde a lâminas-de-machado, pequenas, polidas, picoteadas/lascadas, percutores, almofarizes, moedores, pequenas mãos-de-pilão e pedras corante (hematita).Quarenta e duas datas

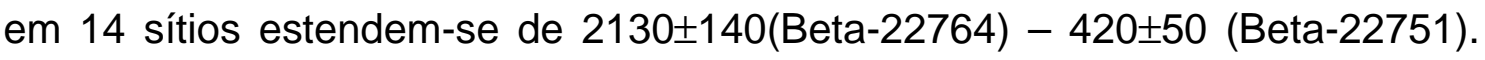
Não há hiatos entre a data mais antiga e a mais recente.

Fase Cupuí 1350£60 AP Miller et alli, 1992

Ocorre entre os sítios da Fase Jamari. São sítios-habitação com terra escura, que não chega a ser considerada TPA, de $0-30 \mathrm{~cm}$, tendo forma circular e subcircular entre $100 \times 100 \mathrm{~m}$ a $160 \times 160 \mathrm{~m}$, e 100 × $130 \mathrm{~m}$ a 260 × $820 \mathrm{~m}$. Localizam-se próximo ao rio Jamari e igarapés e nas cabeceiras de nascentes perenes.

O complexo cerâmico apresenta pasta muito arenosa com temperos: 1) areia, que predomina e aumenta ao longo da seriação 2) cariapé. As formas são predominantemente simples: assadores de beiju entre 39 e $64 \mathrm{~cm}$ de diâmetro. Tigelas rasas em meia-calota com bordas diretas e lábios arredondados, entre 6 e 39cm de diâmetro. Vasos rasos hemisféricos a cônicos de boca e pescoço medianamente constrictos, com bordas diretas a extrovertidas, lábios arredondados e levemente apontados e reforçados externamente, fundo arredondado e plano, entre 12 a $48 \mathrm{~cm}$. Algumas formas lembram a Fase Jamari.

Tipos decorados vão de 1 a 1,8\% do total. O mais popular, o banho de engobo vermelho, o inciso com linhas retas horizontais, oblíquas e paralelas, e o 
roletado. Ocorreram também pesos de fuso, perfurados e retocados, a partir de cacos cerâmicos.

O material lítico corresponde a lâminas-de-machado polidos, abundantes, em geral pequenas, de formas particulares. Percutores em seixo, por vezes retocados, moedores pequenos e arredondados. Possui uma datação de $1350 \pm 60$ AP (Beta-51729).

\section{Fase Matapi 420 - 230 \pm 80 - Miller et alli (1992)}

Sítios-habitação e oficina ocorrem em barrancos altos, próximos do rio, com forma circular, de 80 a $250 \mathrm{~m}$ de diâmetro, ou elipsóide, de 120x70m e $550 \times 200 \mathrm{~m}$. A profundidade máxima foi de $50 \mathrm{~cm}$, recobrindo sítios da Fase Jamari. Contém evidências de Terra Preta Arqueológica.

Apresenta uma cerâmica sem decoração plástica ou pintada, banho ou engobo vermelho. O Antiplástico é cariapé ou com areia, raramente cauxi, cauxi e cariapé; manufaturado por acordelamento; superfícies regularmente alisadas.

As formas são de tigelas rasas e medianas, vasos hemisféricos a globulares, bordas diretas, introvertidas, extrovertidas, lábios arredondados e raramente apontados.

O material lítico engloba fragmentos de lâminas-de-machado, pequenas, polidas, percutores, moedores, pedras bigorna e hematita.

Segundo Miller et. al.(1992), vários sítios colocam esta fase como sucessora da fase Jamari. Três datas colocam o fim da fase Jamari em 420 AP. Uma data de 230 \pm 80 (Beta-22752) em RO-PV-52 é compatível com a hipótese que esta fase seja ligada ao contato com o europeu no inicio da conquista, 1600 A.D.

As maiores diferenças entre as fases da Tradição Jamari estão relacionadas a fase Cupuí (Miller et alli, 1992). Os sítios desta fase ocorrem entre os assentamentos da Fase Jamari. São sítios-habitação com terra escura, que segundo o autor, são mais claras que a TPA, com espessura de $30 \mathrm{~cm}$. Possuem formas circulares e sub-circulares com dimensões horizontais entre 
100 x 100m a 160 x 160m, e 100 x 130m a 260 x 820m. Localizam-se próximo ao rio Jamari em igarapés e nas cabeceiras de nascentes. Em relação a cerâmica, somente nesta fase é diagnosticada o tipo assador de biju ${ }^{11}$.

O médio-baixo Jamari é o local de ocorrência de TPA em Rondônia que possui a cronologia mais elaborada ${ }^{12}$. As Terras Pretas Arqueológicas, desde as mais antigas, até as mais recentes, remontam pelo menos 4000 anos de ocorrência. (Miller et. al. 1992)

\subsection{AS TERRAS PRETAS ARQUEOLÓGICAS}

As TPA's são solos antropogenicos, resultado de atividades humanas ainda não bem definidas, que apresentam alto teor de nutrientes ${ }^{13}$ além de estarem normalmente associados a vestígios arqueológicos como cerâmica, lítico e carvão. (Smith 1980, Kern 1988, Kern \& Kämpf 1989; Sombroek 1966; Woods e MaCann 1999).

O processo de formação da TPA pode estar relacionado ao resultado acidental de um assentamento, conseqüência do descarte doméstico e acúmulo de matéria orgânica de sítios que tiveram uma permanência de longa duração. (Kern, 1988, 1996, Kern e Kämpf, 1989, 2003)

Nem todos os sítios geram este tipo de solo, sua formação estaria ligada a mudanças nos padrões de assentamentos, como apontado por Neves et al (2004). Para os autores o entedimento da TPA é fundamental para a melhor compreensão de temas relacionados a ocupação do território amazônico.

Em Rondônia sítios contendo TPA foram localizados em diferentes locais, ao norte no rio madeira, a oeste no rio Guaporé, e a leste nos rios Jamari e Jiparaná. Ocorrem tanto em ambiente de várzea (rios Madeira e Guaporé), em planície de inundação(Jamari e Jiparaná) e em terra firme (rio Jamari e Jiparaná).

\footnotetext{
${ }^{11}$ Este tipo se refere a bordas diretas com inclinação totalmente horizontal, normalmente mais espessas em relação aos fragmentos da coleção. (Miller et alli, 1992).

${ }^{13}$ como fósforo $(\mathrm{P})$, potássio $(\mathrm{K})$, cálcio $(\mathrm{Ca})$, magnésio $(\mathrm{Mg})$,
} 
Em Miller et alli (1992) encontramos o que atualmente pode ser considerado o surgimento da TPA nos sítios em Rondônia, e o mais antigo registro deste fenômeno na Amazônia. O pesquisador relaciona a formação da TPA ao acumulo de restos orgânicos produzidos por povos que da inicio a uma prática de agricultura incipiente. No sítio RO-PV-48, foram evidenciados restos de coquinhos carbonizados, recuperados em meio a TPA, datando $4130 \pm 160$ (Beta-27406).

Miller (1992, p. 334):

(...)a presença de vários sítios-habitação de terra preta antropogênicas sem cerâmica por tuda sub-região(...)é valido considerar que essa modalidade cultural de caçador-coletoragricultor pré-ceramista foi adotado ampla e extensivamente, perdurando até o presente(...)Histórica e presentemente, ocorrem tribos nesse estágio cultural, como os Mura Pirahã e os Nambikwara. (...)

Esta hipótese também é fundamentada pelas evidências de antropocória disseminação voluntária ou involuntária, feita pelo homem, de plantas daninhas ou cultivadas - identificada nos sítios. Em todos os sítios desta fase a palmeira do Urucurí era abundantes no locais onde houveram ocorrências de terra preta arqueológica.

Para o autor (Miller et alli, 1992, Miller, 1987, 1992 e 1999) a cultura material regatada nestes sítios auxiliaria também no argumento de uma agricultura incipiente, já que artefatos líticos encontrados como: pedras-bigorna, pequenos pilões, pequenas mãos de pilão e pequenos machados, serviriam para a aquisição e processamento dos alimentos.

Nos sítios-habitação das Cachoeiras Teotônio (RO-JP-01 e 03) e Santo Antônio (RO-PV-19), no rio Madeira o contexto é diferente. São extensos sítios da subtradição Jatuarana, com terras pretas arqueológicas que atingem até $680 \times 240 \mathrm{~m}$ de área, e até $2,4 \mathrm{~m}$ de espessura. As datações remontam a $2730 \pm 75$ AP (SI-3950) em RO-JP-01, de amostra a $30 \mathrm{~cm}$ da base da Terra Preta e 2340 \pm 90 AP (Beta-33456) em RO-PV-19, ambas associadas a abundante cerâmica não perturbada e sem evidências pré-ceramistas nas camadas inferiores até o embasamento rochoso (Miller, 1992). 
Neste local Miller (1992, p. 220) alerta sobre a antropocória, ocorre também entre os sítios-lito cerâmicos:

(...)esses testemunhos já foram detectados na Subtradição Jatuarana, ao redor de 2730 \pm 75 AP (SI-3950) e na tradição Jamari, desde pelo menos 2500 \pm 90 AP (Beta-22750). Esta palmeira(Urucuri) se restringe as áreas de terra preta na maioria quase que absoluta dos sítios(...)

A antropocória evidenciada no médio-Madeira, é mais representativa em relação ao que também é observada no rio Jamari. O autor traz detalhes sobre a distribuição destas palmeiras na área:

(...)espécies vegetais foram certamente introduzidas na área dos sítios-habitação, como verificado pela não ocorrência espontânea das mesmas nas áreas de terra firme. É o caso da Palmae 1) Peronoglyfis marajá (marajá), que só ocorre endêmicamente em solos úmidos de igapó, várzea e planície,e 2) Attalea excelsa (urucurí), ocorrendo dentro da área das manchas de terra preta das sub-bacias, raramente na periferia, e excepcionalmente nos arredores dos sítios-habitação. O marajá ocupa o centro ou miolo dos sítios junto à maior concentração de cerâmica, e o urucurí, ocupando a terra preta, traça suas formas e dimensões. Os caroços carbonizados destas palmáceas ocorrem desde o início da formação da terra preta ceramista.(...) A Orbygnia martiana (babaçu), além de fonte de proteina vegetal e animal (larvas), é matéria-prima para a cobertura das casas. Nenhum sítio-habitação foi encontrado em áreas onde esta palmácea esteja ausente. O Astrocarium tucumã (tucumã) é mais abundante na periferia dos sítios-habitação. A Guilielma gasipaes (pupunha) e a Guilielma insgnis (chonta), quando presentes, são junto a sítios-habitação com terra preta.(...) (Miller, 1992 p. 221-222)

E na foz do rio Jiparaná:

(...)A palmeira do Urucurí, é indicadora de sítios-habitação, e ocupa sempre porção de terra-preta dos sítios, a palmeira Marajá aponta as concentrações de cerâmica mais densa, e o Babaçu sempre circunda os sítios, penetrando na coroa de terra cinzenta.(...)(Miller, 1987relatariomadeira)

As vastas evidências do fenômeno da antropocória, e o adensamento de palmeiras em áreas bastante amplas, podem sugerir uma intensa atividade 
agrícola itinerante, assim como manejo e controle de determinadas espécies ${ }^{14}$, também praticada na terra firme, evento que pode proporcionar maior estabilidade para os grupos, contribuído assim, no processo de formação da TPA nos sítios.

Entretanto, Miller $(1992,1999)$ interpreta a formação da TPA - tanto dos sítios da bacia do Jamari, quanto dos assentamentos do rio Madeira, como resultado de constante reocupação dos assentamentos:

(...)Manchas de terra preta(...) ocorrem em terra firme e diques marginais, são resultantes da antropogênese(...)se formam em conseqüência da concentração de restos orgânicos vegetais, animais e seus dejetos, por queima e decomposição em chão de sítioshabitação indígena(...)O concentrador desta composição é a maior permanência e sobretudo as reocupações dos sítioshabitação(...)(Miller 1992, p. 220)

E, em relação aos sítios do médio rio Madeira, Miller (1999, p.337), sustenta que:

(...)Principalmente entre as cachoeiras Teotônio e Santo Antônio, a concentração de grandes, espessas e densas camadas de terras pretas antropogênicas, com cerâmica contínua horizontal e verticalmente, é compatível com uma intensa e constante reocupação de sítios- habitação.(...)

As constantes reocupações nos sítios, para o pesquisador, são indicadas a partir do estudo da seqüência seriada da cerâmica, e não atribuído a interrupções de presença de material arqueológico entre as camadas estratigráficas.(1987riomadeira, p.31) comenta que nos sítios da subtradição Jatuarana na foz do rio Jiparaná a cerâmica é abundante por todo estrato arqueológico, desde a superfície.

Outro ponto observado Miller et alli (1992) e Miller (1992) se relaciona a alternância de camadas de solo de terra preta destes sítios. Seriam ora mais escuras, ora mais claras, resultado de alterações climáticas, ora de maior, ora de menor umidade, fatores estes responsáveis pela constante reocupação dos assentamentos. Miller (1992, p. 221):

\footnotetext{
${ }^{14} \mathrm{O}$ que observamos atualmente são as palmeiras, mas com certeza o número de espécies vegetais manipuladas deveria ser bem maior.
} 
(...)camadas de terra preta mais escura devem refletir períodos de maior umidade, permitindo reocupações mais intensivas e freqüentes, enquanto as camadas mais claras devem evidenciar menos umidade, com menor índice demográfico ou ocupação menos prolongada(...)

Diferentemente, alguns estudos apontam (Herrera et. al.1992, Heckenberger, 1998, Roosevelt, 1989, 2002, Mora et. al. 1992) que sítios extensos contendo TPA são interpretados como ocupações permanentes ou semi-permanentes, de longa-duração, durando séculos, de populações que praticavam a agricultura.

As propriedades físicas e morfológicas, dentro dos sítios com TPA não são uniformes, segundo Kern (1988 e 1996), suas variações são explicadas por diferentes atividades, estando relacionadas à preparação de alimentos, a agricultura e ao descarte de resíduos orgânicos. Kämpf e Kern (2003), apontam que esta variabilidade dificulta a inferência a na observação de, por exemplo, taxa de acumulação, tempo de ocupação e da densidade da população que habitava o local.

Kämpf et al. (2003) e Kämpf e Kern (2003) mencionam que atualmente está confirmado, que a Terra Preta se forma a partir de atividades humanas relacionadas à assentamentos e práticas agrícolas de indígenas précolombianos (Smith, 1980; Eden et al., 1984; Pabst, 1985; Andrade, 1986; Correa, 1987; Mora et al., 1991; Kern, 1988 e 1996).

Concentrando-se ao longo dos rios e na terra firme interior:

(...)Tais assentamentos foram mantidos por formas relativamente intensas de agricultura permanente e semi-permanente, em vez de cultivos itinerantes com longos pousios usuais entre a maioria dos indígenas contemporâneos. Arqueo-antrossolos, conhecidos como terra preta (TP) e terra mulata (TM), são registros desses assentamentos associados com cultivos intensivos. A sua ocorrência nas mais diversas classes de solos mostra que solos antrópicos férteis suportando cultivos produtivos podiam ser criados quase que em qualquer lugar. (...)(Kämpf e Kern (2003, p.8)

A hipótese levantada por Miller pode estar relacionada com o modelo de interpretação elaborado por Meggers (1971, 1977, 1990, 1996 e 2001) em que a Amazônia não teria condições de sustentar ocupações duradouras, estáveis. 
A maioria das interpretações está baseada a partir da observação de mudanças na cerâmica arqueológica, em estudos abalizados em seqüências de seriação cerâmica, sítios - inclusive com terra preta arqueológica - que ocupam áreas amplas de superfície, e que representariam sucessivas reocupações durante séculos, em vez de uma única ocupação grande e permanente.

\subsection{CONTEXTO DO RIO JIPARANÁ}

Os dados arqueológicos, para a bacia do rio Jiparaná, não possuem referências cronológicas. Contudo, principalmente em relação à presença de ocupações lito-cerâmicas temos uma série de informações disponíveis. É a partir da publicação de relatórios resultado de projetos de arqueologia de licenciamento ambiental, que hoje temos conhecimento de pontos em áreas do alto, médio e baixo Jiparaná. (Miller 1987a, 1987b, Bueno e Machado, 2005 e Scientia 2006, 2008). São numerosas as fases arqueológicas estabelecidas, sendo catorze cerâmicas e três líticas (Vilhena, Taiassú e Itapema). A cerâmica foi relacionada em parte a subtradição Jatuarana - Tradição Polícroma da Amazônia(Miller, 1987a, 1992, 1999) e fase Guarita (Miller, 1987b) - à Tradição Tupiguarani, além de fases sem relação com nenhuma tradição arqueológica definida (Miller, 1987a, 1987b).

$\mathrm{Na}$ área do baixo Jiparaná os dados são pontuais. Em sua foz com o rio Madeira foi apontado dois sítios arqueológicos (RO-CA-01 e 02), relacionados a subtradição Jatuarana. Estão situados próximos a diques marginas do rio Jiparaná, sobre os interflúvios, em terra firme, delimitados pela terra preta arqueológica, com espessura entre 55 a $70 \mathrm{~cm}$ e dimensões de $550 \times 210 \mathrm{~m}$ e $420 \times 190 \mathrm{~m}$.

Em seu médio curso, entre a cidade de Jiparaná e a foz do rio Anari, encontramos na bacia uma grande diversidade de fases arqueológicas cerâmicas, além de três fases líticas ${ }^{15}$. É Miller (1987a, 1987b) quem

\footnotetext{
${ }^{15}$ As fases líticas não possuem tradição determinada. A Fase Vilhena, no município homônimo, compreende raspadores circulares e laterais, lascas simples e com evidências de modificação e uso, núcleos e seixos com retirada, em arenito e sílex. Possui três datações:
} 
estabelece estes dados, e discute principalmente a presença da Tradição Tupiguarani no local, representada por sete fases diferentes.

Os tipos roletado, inciso, corrugado e ungulado estão presente em praticamente todas as fases associadas à Tradição Tupiguarani. Assim como o antiplástico de areia, grossa e fina; em raros casos ocorre o cariapé - na fase Urupá e em poucos fragmentos da fase Inimbó. (Miller, 1987b)

$4385 \pm 70$ AP (SI-2763), 3750 \pm 110 (SI-2761) e 2155 \pm 95 anos AP (SI-2762). As fases Itajuba e Itapema ocorrem em sítios no município de Ji-paraná, em ambas são encontradas lascas simples, percutores e núcleos. A diferença esta na fase Itapema, portadora de talhadores.(Miller, 1987os dois relata) 


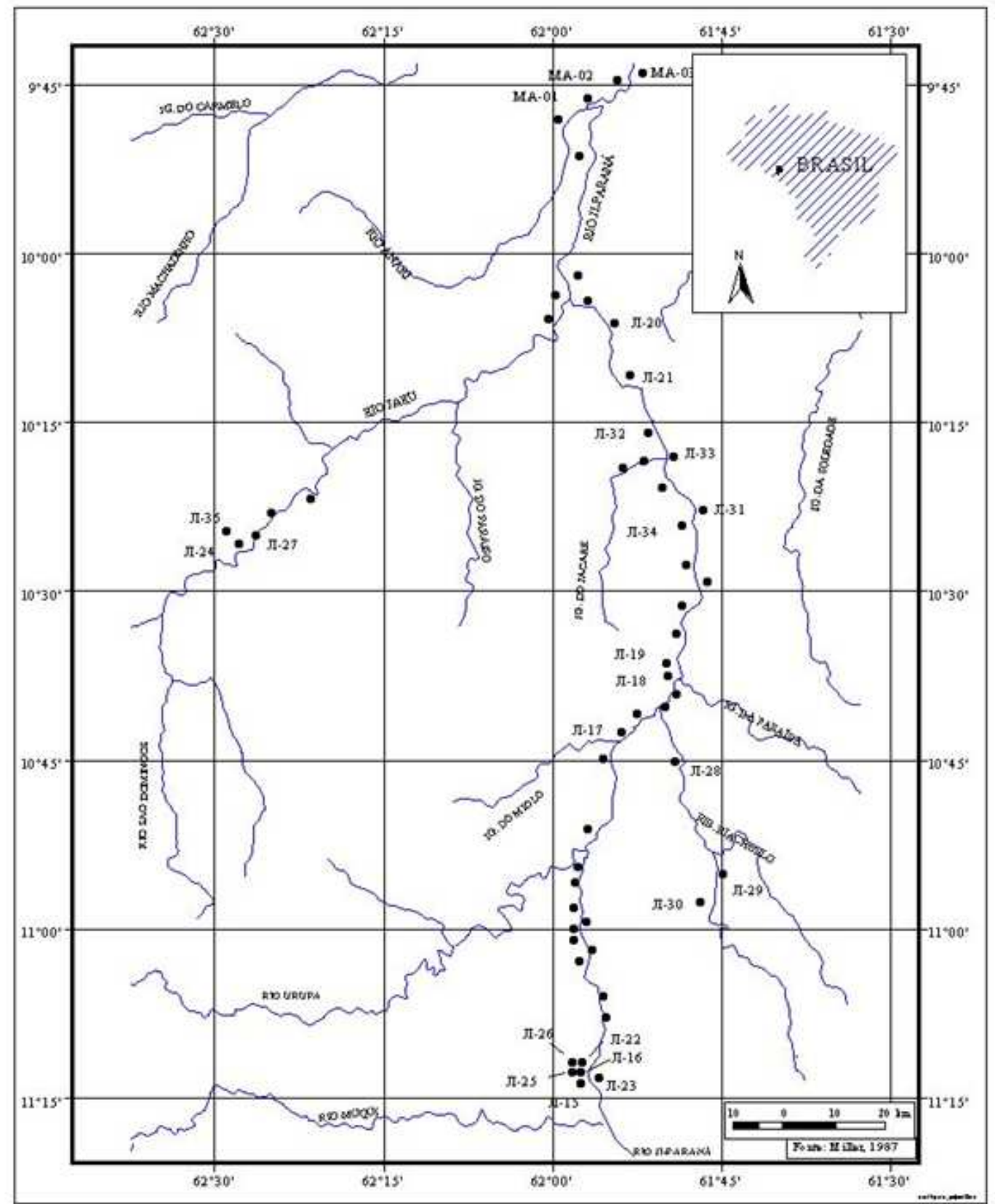

Imagem 20: Sítios arqueológicos com TPA, no médio Jiparaná, localizados por Miller (1987)

Os sítios, distribuídos em toda a extensão da área, foram localizados adjacentes a planície de inundação dos principais cursos d'água, em terra firme. Suas dimensões variaram em $120 \times 150 \mathrm{~m}$ a $300 \times 300 \mathrm{~m}$. A camadas de ocupação mais espessa é registrada na fase Urupá, atingindo $60 \mathrm{~cm}$. Nos sítios das demais fases a espessura variou entre 35 e $45 \mathrm{~cm}$ de profundidade.

Entre os locais de ocorrência das fases Tupiguarani, existem outros assentamentos associados a mais seis fases cerâmicas, sem tradição definida, ambas caracterizadas como não tupi por Miller (1987a, 1987b). Os traços 
comuns destas fases seriam a pouca presença, ou ausência de tipos decorados, com exceção da fase Jaru. O antiplástico é a areia, com raros casos de cariapé na fase Ironçaba. (Miller, 1987b)

Nas fases Araça e Ironçaba, são encontrados sítios de menor porte - 45×32m e 130×100m respectivamente - com camadas arqueológicas de menor espessura, entre $15-20 \mathrm{~cm}$. Sítios maiores são associados as fases Jaru (170×105m), Quiiba(239×110m), Graúna(180×290m) e Imbirissú (190×150m), sendo a espessura predominante dos estratos arqueológicos de $40 \mathrm{~cm}$.(idem).

Uma das características desta área, é que mesmo havendo uma diferença na coloração do solo dos sítios em relação ao solo vizinho, não se formou a Terra Preta Arqueológica em nenhum local.

A seguir podemos acompanhar uma tabela com as principais características das fases cerâmicas encontras em toda a extensão do rio Jiparaná.(Tabela 1) 
Tradição Tupiguarani
Médio rio Jiparaná
Antiplástico: Cariapé, cauxí e/ou carvão. Decoração plástica: exciso raspado, inciso dupla linha, ponteado, ponteado arrastado, ungulado, pinçado, serrungulado, serrilhado fino, estampado, carimbado apliques zoomórficos, antropomórficos, Pintura: monocromias engobo vermelho, policromias sobre engobo branco ou não, com as cores preta, marrom, magenta, vermelho, laranja, amarelo e creme, exciso raspado e acanalado fino, retocados ou preenchidos com branco, amarelo, laranja e vermelho.Morfologia: simples e compostas, desde pequenas tigelas a urnas antropomórficas.

Antiplástico: de rocha basáltica alterada com areia e mica. Predomina o tempero fino. Decoração plástica: inciso em linhas paralelas. Morfologia:Vasilhames de pequeno a médio,tigelas e vasos, bordas diretas e levemente extrovertidas, base levemente cônico e arredondada.

Antiplástico: grosso de areião e rochas degradadas com areia, boa quantidade de tempero fino com areia e raramente mica, Decoração (15\%) plástica: inciso, inciso-roletado, roletado. Morfologia: Tigelas e vasos, diretas e extrovertidas, bases pronunciadas formando carenas, bases planas.

Antiplástico de quartzo moído, raros cacos com mica e tempero de areia fina.. Decoração (10\%) plástica: corrugado, roletado, inciso. Morfologia: Vasos globulares com bordas diretas a extrovertidas, base arredondada

Antiplástico de quartzo moído e rochas degradadas com areia, em quantidade inferior ao tempero médiofino de areia. Decoração(15\%) Plástica: corrugado, ungulado, roletado, inciso roletado, roletado
2730 $\pm 75-\quad$ Miller

$2340 \pm 90$ AP $\quad(1987 a)$ 
Ironçaba

Fase
Médio rio Jiparaná

Médio rio Jiparaná

Médio rio Jiparaná

Médio rio Jiparaná

Médio rio Jiparaná

Médio rio Jiparaná

Médio rio Jiparaná

Médio rio Jiparaná

corrugado-ungulado, inciso, borda acanalada, apliques mamiliformes. Morfologia: Vaslhames pequenos a médios raramente grandes. Formas de tigelas a vasos, bordas diretas a extrovertidas e base arredondada, as vezes perfurada.

Antiplástico: Cariapé, areia grossa e fina. Decoração (7\%) Plástica: corrugado, ungulado, corrugado-ungulado, serrungulado, roletado, inciso. Pintura: Engobo vermelho,pintura (branca ou preta) Morfologia: Tigelas em meia calota e meia esfera, vasos esféricos, cônicos e carenados, assadores.

Antiplástico: Areia grossa e fina e raro cariapé. Decoração Plástica:(10\%)marcado com corda, ponteado, ungulado, Pintura: branca e engobo vermelho.

ND

Antiplástico de rocha alterada e areia, predomina o fino. Decoração plástica( $5 \%$ : inciso. Morfologia:Vasilhames pequenos, raramente médios. Formas de tigelas a vasos cilíndricos a globulares, de bordas diretas a suavemente extrovertidas, com base arredondada, as vezes plana.

Antiplástico: areia grossa fina e raro cariapé. Decoração(14\%) Plástica:inciso, inciso-roletado, acanalado, acanalado-inciso 
Fase

ND

Antiplástico de rocha alterada e areia grossa.

Presença de engobo vermelho. Morfologia:

Vasilhames pequenos, tigelas a vasos globulares.

engobo vermelho

Tabela 1 - Fases cerâmicas no rio Jiparaná. (A partir de Miller, 1987a,1987b)

ND: Não definido * Relacionadas a aspectos que pudessem ser comparáveis entre a bibliografia disponível. Quando houve menção a proporção de tipos decorados estes foram indicados em \%. 
O alto Jiparaná, desde sua nascente até a cidade de Ji-Paraná, demarca a uma área de transição da floresta amazônica com a savana. Neste trecho possuímos dados resultantes de pesquisas arqueológicas requeridas para 0 licenciamento ambiental de uma linha de transmissão de energia, de $230 \mathrm{kV}$, com uma extensão de $279 \mathrm{~km}$, interligando os municípios de Ji-Paraná e Vilhena $^{16}$.

Bueno e Machado (2005) identificaram para área do empreendimento um total de 50 sítios arqueológicos, sendo 31 sítios lito-cerâmicos, seis sítios líticos, cinco sítios oficinas de polimento, cinco sítios com gravuras rupestres e um sítio lito-cerâmico com oficina de polimento associado. (Imagem 20).

De uma maneira geral, o local pode ser dividido em duas partes: $O$ trecho ao sul, entre as cidades de Pimenta Bueno a Vilhena, e o norte, entre Pimenta Bueno e Ji-Paraná.

A porção sul é caracterizada pela presença da vegetação de cerrado e solos arenosos. Lá foi evidenciado um pequeno número de sítios arqueológicos líticos, associados principalmente a dois contextos em terra firme: topos de morros com oferta de matéria prima lítica, e, próximo a pequenos cursos d'água(Bueno e Machado,2005)

Mais ao norte, a vegetação é caracterizada por ser uma zona de transição entre o cerrado fechado mais ao sul, e a floresta tropical. Possui solo mais argiloso, com maior quantidade de material orgânico. Existe também um aumento na densidade de cursos d'água, assim como no porte dos rios e córregos em relação ao trecho sul. Aqui foram encontrados todos os sítios litocerâmicos da área, estes situados em terra firme, sobre terreno suave ondulado, nas planícies próximas ao rio Jiparaná. (idem)

16 Levantamento arqueológico, Bueno e Machado (2005), Resgate arqueológico: SCIENTIA(2005), Relatório Parcial: (2008) 
Imagem 21 MAPA DOS SITIOS 
Dois sítios em especial, adjacentes a planície de inundandação do rio Jiparaná, fornecem dados importantes. Os sítios Nova Arizona(RO-JP-02) e Terra Queimada (RO-JP-03) $)^{17}$, distante $7 \mathrm{~km}$ na planície do rio Jiparaná, resultaram uma área com ocorrência arqueológica de $750 \times 350 \mathrm{~m}$. Lá, a camada arqueológica predominante foi de $30 \mathrm{~cm}$ de espessura.( Imagem 22)

Segundo Scientia (2008) a cerâmica dos sítios são muito semelhantes a dos sítios arqueológicos relacionados a Tradição Tupiguarani, já identificada por Miller (1987b) na região. Os potes costumam ter formas simples, com poucas carenas. A composição da pasta contém pouco ou nenhum acréscimo de temperos, além dos presentes nas fontes de matéria-prima (quartzo, areia, hematita, feldspato e mica). As decorações são pouco freqüentes, sendo a decoração plástica a mais abundante, com oito tipos: inciso roletado, inciso cruzado, inciso fino, inciso largo, ponteado, roletado, ungulado, corrugado. A decoração crômica é representada pela: pintura vermelha sobre engobo branco,pintura branca, pintura vermelha e engobo vermelho. (Imagem 23)

No sítio Terra Queimada foram datados três pontos, em um local considerado uma estrutura de descarte (denominada Lixeira). A datação resultou uma cronologia entre $1220 \pm 40$ e $1080 \pm 40$ anos AP para a ocupação do assentamento. A situação estratigráfica das amostras pode apontar o caráter antropogênico desta estrutura, assim como uma permanência na ocupação do local de aproximadamente 300 anos. (Imagem 24)

O sítio Torre 73-1(RO-CA-02), próximo a Cacoal-RO, possui uma dimensão de $190 \mathrm{~m} \times 240 \mathrm{~m}$. Apresenta uma camada de ocupação de aproximadamente $40 \mathrm{~cm}$, chegando em alguns pontos a $70 \mathrm{~cm}$. Segundo Scientia (2008), a cerâmica do sítio possui características divergentes dos sítios pertencentes à Tradição Tupiguarani na área. A tecnologia empregada para o preparo da pasta (como a adição de areia) não ocorre nos demais sítios, assim como a morfologia dos vasilhame é bastante peculiar: grande pratos (assadores) com tratamento de superfície roletado, e panelas com bordas acanaladas. Segundo

\footnotetext{
${ }^{17}$ Segundo Scientia (2008) os dois assentamentos são considerados atualmente como um só, dado a proximidade entre os locais, a continuidade de material arqueológico entre os pontos, além de cerâmicas muito semelhantes.
} 
os pesquisadores os dados até o momento permitem associar a fase Jarú (Miller, 1987b). 
22,23,24 FIGURA NOVA ARIZONA E TERRA QUEIMADA 
Miller aponta uma possível origem para a Tradição Tupiguarani na região, ao relacionar o modelo de origem lingüística com à arqueologia. Pesquisadores como Rodrigues (1964) e Migliazza (1982) apontam como centro de dispersão do Tronco Lingüístico Tupi, a região de Ji-Paraná-RO, pois diversidade de famílias lingüísticas pertencentes ao tronco identificadas na região sugeriria o fato. E, onde a origem de tronco lingüístico tupi (origem da tradição cerâmica) seria onde fosse registrada a maior ocorrência de variedade de famílias lingüísticas (nesse caso, as fases cerâmicas).

A interpretação a partir dos dados lingüísticos, é ao mesmo tempo arqueologicamente interessante e polêmica, dada a discussão da associação dos grupos falantes Tupi e a tradição cerâmica Tupiguarani (Lathrap1970, Brochado, 1984, Schmitz, 1991; Noelli, 1996).

Como vimos, no trecho do médio Jiparaná não foram encontrados sítios arqueológicos que formaram Terra Preta Arqueológica. Já para esta área do alto Jiparaná, Bueno e Machado (2005) localizam dois pontos de ocorrência de TPA, em contexto semelhante, na terra firme, distante $20 \mathrm{~km}$ do rio Jiparaná. O sítio RO-MA- $01^{18}$, apresentou terra preta arqueológica nos primeiros $30 \mathrm{~cm}$ das tradagens, além de vestígios cerâmico com até $60 \mathrm{~cm}$ de profundidade. No local encontram-se diversas palmeiras de babaçu, bacuri e inajá.

Deste ponto, até a ocorrência seguinte são $10 \mathrm{~km}$. Denominado sítio Encontro (RO-MA-05), trabalhos de escavação no local constataram dois pontos de ocorrência de TPA no assentamento. O estudo deste sítio, que será tratado no próximo capitulo, pode auxiliar na discussao não só arqueologia da bacia do rio Jiparaná, mas também na arqueologia do Estado de Rondônia, como será discutido no capítulo 4.

Para finalizar as considerações sobre o contexto arqueológico desta área que se insere o sítio em estudo, cabe mencionar o fato da farta ocorrência de machados arqueológicos em todos os pontos da região do alto-médio Jiparaná.

\footnotetext{
${ }^{18}$ Este sítio está preservado, e o único trabalho realizado foi o de localização, feito pela equipe de Machado e Bueno. Não havendo impacto pelo empreendimento, não foram realizadas escavações no local.
} 
São encontrados instrumentos líticos polidos dentro do Estado em praticamente em todas as fases e subtradições.

$\mathrm{Na}$ área do médio baixo Jiparana a quantidade destes vestígios é impressiona ainda mais. Tanto Bueno e Machado (2005) quanto SCIENTIA (2005) ressaltam a densidade de vestígios líticos encontrados, principalmente machados polidos, percutores e "adornos". Também é impressionante a quantidade de coleções particulares desses materiais, que são provenientes em grande parte das proximidades do rio Jiparaná, também conhecido na região como Rio Machado. Foram diversos os moradores que relataram ter suas coleções particulares. Alguns começam a coleção, mas depois param, dizendo enjoar, a oferta de machados é tão grande, que cansa até de colecionar.

Resolvemos conhecer uma destas coleções particulares. Foi impressionante, com mais de 100 artefatos, de diferentes tipos e matérias-primas. Uma amostra da riqueza das formas pode ser vista na imagem 25.

A grande quantidade destes instrumentos é proporcional também com a quantidade de polidores e amoladores evidenciados nas margens dos igarapés e rios da região entre Jiparaná e Pimenta Bueno. Em diversas fases cerâmicas Miller observa que sítios oficina lítica estão sempre associados aos sítios cerâmicos.

Nos sítios escavados pela Scientia (12), em dez foram encontrados machados tanto em superfície como in situ.

A presença de uma quantidade altíssima de machados polidos localizados tanto in situ, quanto em coleções particulares, sugere-se a vasta utilização desses artefatos em atividades provavelmente relacionadas ao manejo do meio ambiente - preparo de roças, derrubada de árvores. Segundo Bueno e Machado (2005) tal intensidade de utilização estaria indicada não apenas pela quantidade com que esses artefatos são encontrados na região, mas também pelos indícios de constante reavivagem de gumes, aspecto esse indicado, por sua vez, pela presença de inúmeros polidores e afiadores fixos e pela intensidade de modificação que esses artefatos apresentam. Além disso, da 
Imagem 25 
ocorrência abundante também pode ser resultado de um uso continuo do artefato por um longo período de tempo.

Ainda vamos aprofundar a questão, mas, de certa forma, podemos pensar que a especialização num tipo de artefato que pode ter contribuído para 0 estabelecimento de quem sabe um tipo de economia combinada com a agricultura itinerante, possibilitando o estabelecimento de grupos em áreas nucleares, também nos interfluvios. 


\section{CAPÍTULO 3 - SítIO ENCONTRO (RO-MA-05)}

(...) com cara de laço novo cheguei, já estava meu povo

E alguém gritou quando já dava cavalo:

- Lace o tobiano capincho pra esses que vem dos bochincho do rincão do Cantagalo(...)

Noel Guarany

\subsection{ApResentação}

O sítio arqueológico Encontro (RO-MA-05) está localizado no município de Ministro Andreazza, estado de Rondônia. Inserido geomorfologicamente no Planalto Dissecado Sul da Amazônia (RADAM, 1976), situa-se no topo de uma colina, com $303 \mathrm{~m}$ de altitude em relação ao nível do mar, num relevo suave ondulado, em uma área de $12000 \mathrm{~m}^{2}$ - 120x 100m (SCIENTIA, 2006).

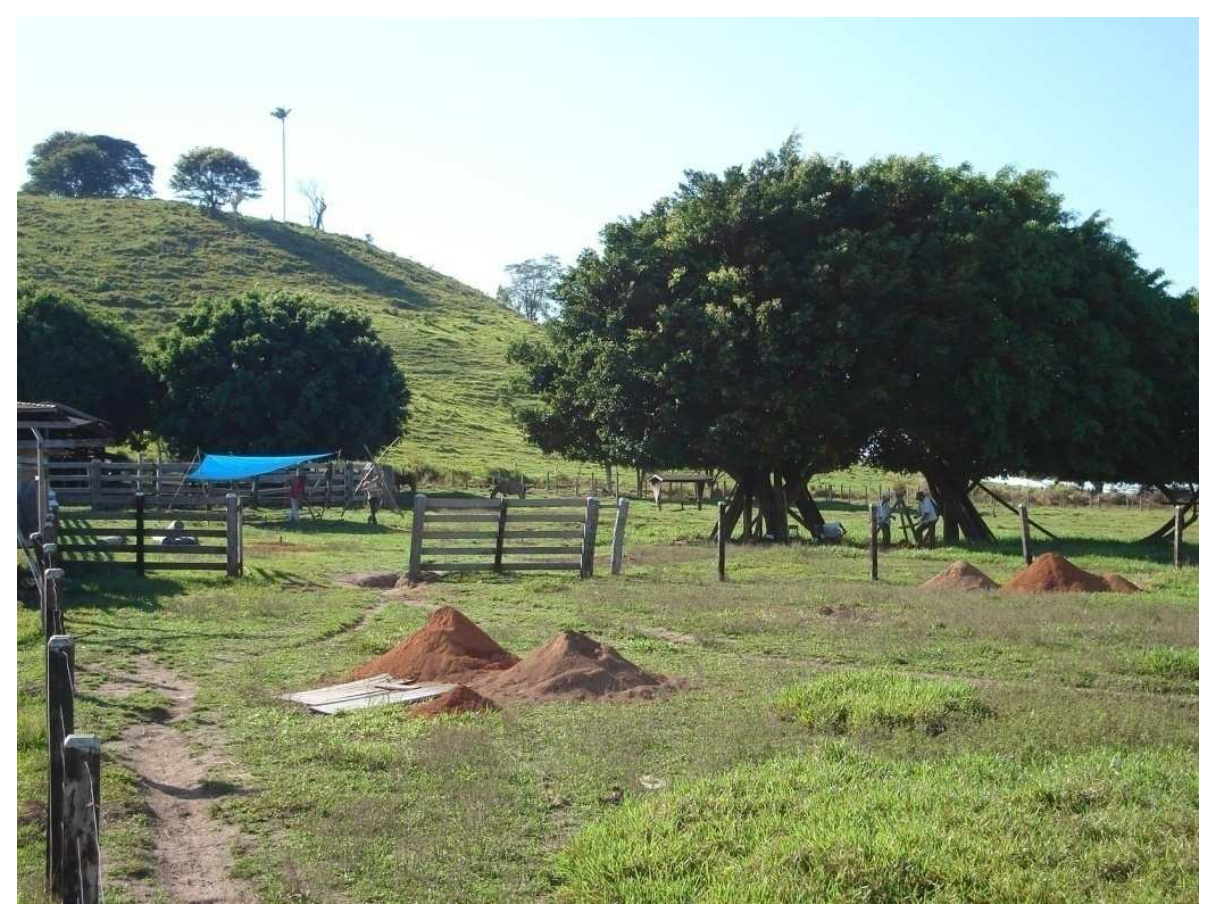

Imagem 26: Perspectiva SE do Sítio Encontro. Foto: Sirlei Hoeltz

Ladeando o local é comum encontrar nascentes, olhos d'água e córregos temporários. O igarapé mais próximo é o Encontro a cerca de 500m. Este está inserido na sub-bacia do rio Ji-paraná esta a 22km do sítio arqueológico.

Atualmente o local está dentro de uma fazenda, destinada a criação de gado bovino e caprino, sendo parcialmente impactado pela construção de locais para 
o manejo do gado ${ }^{19}$. O pasto cobre toda a extensão do assentamento onde originalmente teria uma vegetação do tipo Floresta Ombrófila Densa, característica destas áreas mais altas do sudoeste, formada basicamente por palmeiras, trepadeiras e árvores de médio e grande porte (IBGE,1997).

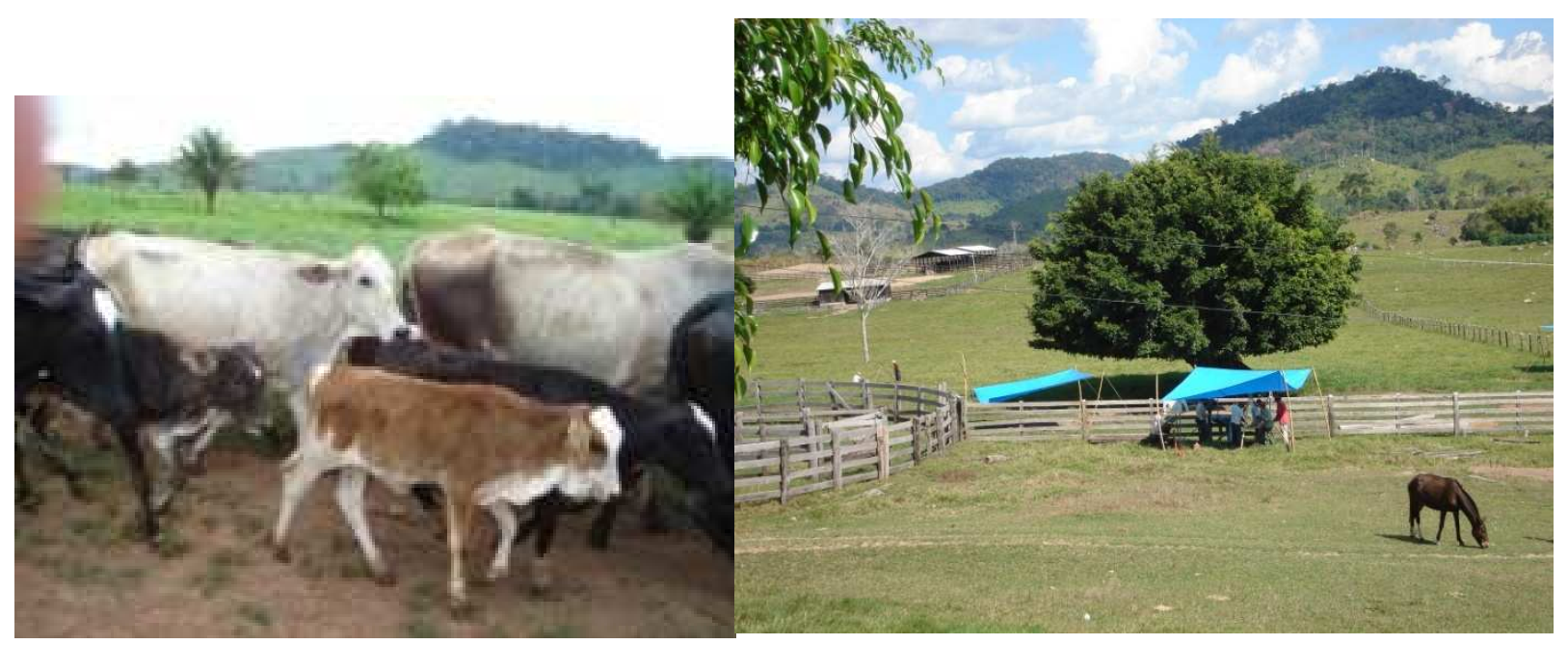

Imagem 27: À esquerda o pisoteamento do gado que afeta constantemente a área do sítio, e à direita: as construções que impactaram 0 assentamento. É possível também perceber nesta imagem o relevo ondulado característico da região.

\subsection{PROCEDIMENTOS}

As pesquisas realizadas no sítio, como citado anteriormente, inserem-se em um grande projeto executado pela Scientia Consultoria, requisito para a construção de uma linha de transmissão de energia. Deste modo, o objetivo da escavação seguiu diretrizes que contemplam buscar resgatar informações das áreas diretamente impactadas, assim como procurando trabalhar com a totalidade do assentamento, em áreas de impacto indireto, seguindo uma forma de amostra sistemática (Scienta, 2005).

Os procedimentos de pesquisa de campo foram coordenados pela arqueóloga $\mathrm{Dr}^{\mathrm{a}}$ Sirlei Hoeltz. Participou também a geoarqueóloga $\mathrm{Dr}^{\mathrm{a}}$ Dirse Kern,

\footnotetext{
${ }^{19}$ Como mangueiras, cochos de sal, rodeio e um posto.
} 
responsável pela parte de solos. As escavações foram realizadas em duas etapas:

A primeira em uma área de $40 \mathrm{~m} \times 40 \mathrm{~m}$, no local de construção da torre de energia, aplicando uma malha de $10 \times 10 \mathrm{~m}$. Nestes pontos foram realizados cortes-teste de $1 \mathrm{~m} \times 1 \mathrm{~m} \times 0,5 \mathrm{~m}$, em níveis artificiais de $10 \mathrm{~cm}$. No final da sondagem era realizada uma tradagem adicional de $0,5 \mathrm{~m}$ de profundidade, no centro, a fim de verificar a existência de material arqueológico em níveis mais profundos. A cada quatro cortes-teste, um foi aprofundado até $1 \mathrm{~m}$, e também nestes foi realizada uma tradagem central. Cada sondagem foi denominada a partir de sua distância (em metros) do ponto zero, balizados pelos pontos cardeais, em um ponto localizado no centro desta malha.

Nesta malha de $10 \mathrm{~m} \times 10 \mathrm{~m}$, aplicada em uma área de $16000 \mathrm{~m}^{2}$, totalizou-se 24 sondagens escavadas. Após a escavação, as sondagens se estenderam no sentido norte/sul e leste/oeste, a fim de delimitar o assentamento. Como resultado, percebemos que o sítio é naturalmente balizado a oeste por um igarapé, ao norte por um açude e para leste, por um cerro de forte aclive. Para o sul a delimitação é uma estrada vicinal, que impactou parcialmente o final do sítio. (SCIENTIA 2006)

Na segunda etapa de escavação, aplicou-se uma malha de 30x30m, no espaço de $120 \mathrm{~m} \times 100 \mathrm{~m}$, resultado desta delimitação. Foram realizados 20 cortesteste, procedendo à escavação da mesma maneira que a etapa anterior. 
Imagem 28: escavação encocpntp e planimetria do sítio. Fonte: Wanderson Esquerdo, SCIENTIA, 2006 Montagem e adaptacão do autor 


\subsection{Resultados}

\subsubsection{Malha 10x10m}

Das 25 sondagens previstas para esta malha, foram escavadas 24, pois o local correspondente ao corte-teste N6 E8 não pode ser trabalhado devido à presença de uma tapera. Grande parte do material arqueológico ficou concentrado entre $10-30 \mathrm{~cm}(75,13 \%)$, tendo como profundidade máxima os 90 $\mathrm{cm}$ de profundidade na sondagem N20 E9. O total de material encontrado nesta malha foi:

\begin{tabular}{cc}
\hline Cerâmica & Lítico \\
\hline 5325 & 188
\end{tabular}

Tabela 2: Quantidade de material

\begin{tabular}{ccc}
\hline Nível & Quantidade & $\%$ \\
\hline $0-10 \mathrm{~cm}$ & 426 & 8 \\
$10-20 \mathrm{~cm}$ & 1678 & 31,52 \\
$20-30 \mathrm{~cm}$ & 2322 & 43,61 \\
$30-40 \mathrm{~cm}$ & 722 & 13,56 \\
$40-50 \mathrm{~cm}$ & 64 & 1,2 \\
$50-60 \mathrm{~cm}$ & 41 & 0,76 \\
$60-70 \mathrm{~cm}$ & 35 & 0,65 \\
$70-80 \mathrm{~cm}$ & 24 & 0,45 \\
$80-90 \mathrm{~cm}$ & 13 & 0,24
\end{tabular}

Tabela 3: Quantidade de material cerâmico por nível

$\mathrm{Na}$ escavação da sondagem N4 E22 foi evidenciada pela primeira vez na pesquisa a Terra Preta Arqueológica. Em todos os pontos circunvizinhos escavados a coloração do solo é mais clara em relação à TPA (10 YR 4/2, 4/1 e solos vizinhos 7,5 YR 4/4, 4/2) Uma das características destes solos escuros é justamente uma maior freqüência de material arqueológico em relação às demais unidades. Caso que se confirma no sítio, a quantidade de fragmentos cerâmicos recuperados desta sondagem foi o maior em relação a toda a escavação ${ }^{20}$, representando $10,1 \%$.

${ }^{20}$ Tanto malha $10 \times 10 \mathrm{~m}$, quanto $30 \times 30 \mathrm{~m}$ 


\begin{tabular}{cc}
\hline nível & cerâmica \\
\hline $0-10 \mathrm{~cm}$ & 4 \\
$10-20 \mathrm{~cm}$ & 94 \\
$20-30 \mathrm{~cm}$ & 607 \\
$30-40 \mathrm{~cm}$ & 50 \\
$40-50 \mathrm{~cm}$ & 8 \\
$50-60 \mathrm{~cm}$ & 4
\end{tabular}

Tabela 4: Quantidade de fragmentos cerâmicos por nível na sondagem N4 E22

Além da escavação, houve também um trabalho de descrição e coleta de solos no perfil SE da sondagem, para fins de caracterização da estratigrafia.

Nesta malha houve três pontos em especial onde o as camadas arqueológicas atingiram entre $70-90 \mathrm{~cm}$ de profundidade - N20E9, S2 E14, S4 W22. Estas sondagens estão próximas a ocorrência de TPA (S4 E22) e também apresentaram solos mais escuros em relação as demais sondagens (7,5YR 4/4 e 4/2 nos níveis com abundância de material arqueológico - entre $10-40 \mathrm{~cm}$ ). Nestes sentido a sondagem S20 W11 também apresentou uma camada mais escura (10YR 4/3), contudo mais espessa entre $0-20 \mathrm{~cm}$, mas com grande quantidade de cerâmica ${ }^{21}$ (Imagem 29)

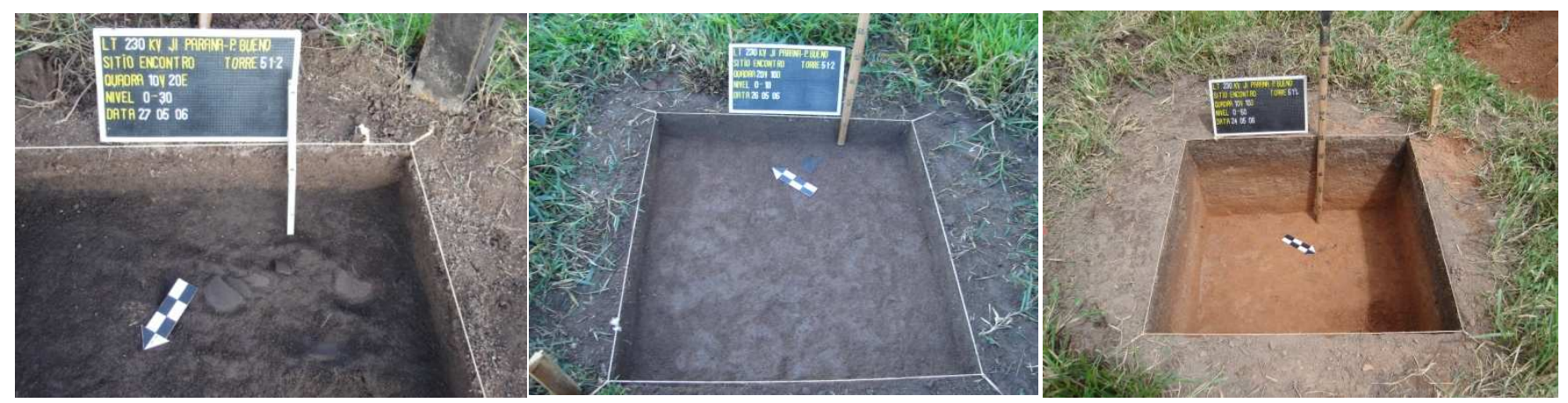

Imagem 29: a esquerda sondagem S4 E28, no centro S22 E4, e a direita S20 W11

\footnotetext{
${ }^{21} 8,9 \%$ do total da escavação
} 
Imagem 30 densidade 10x10[ Imagem 13 quantidade de cerâmica escavada por sondagem na primeira fase ] 


\subsubsection{Malha $30 \times 30 \mathrm{~m}$}

Das 20 sondagens escavadas na malha de $30 \mathrm{~m} \times 30 \mathrm{~m}$, em 18 foi constatado a presença de material arqueológico. Em S28 W74 e S127 W3 não foram encontradas evidências arqueológicas. A profundidade máxima da camada cultural foi um pouco menor que a malha anterior, atingindo os $70 \mathrm{~cm}$, na sondagem S48 E54.

\begin{tabular}{cc}
\hline Lítico & Cerâmica \\
\hline 121 & 2293
\end{tabular}

Tabela 5: Quantidade de Material escavado na malha

O material arqueológico ficou quase na sua totalidade concentrado entre 0 e 30 $\mathrm{cm}$, sendo que no nível $10-20 \mathrm{~cm}$ concentra-se $41,3 \%$ do total da cerâmica escavada na malha $(0-10 \mathrm{~cm}: 15,39 \%, 20-30 \mathrm{~cm}: 31,06 \%$. Quanto ao material lítico encontrado nessa área tem-se: $28,10 \%$, no nível $10-20 \mathrm{~cm}$ (34 itens) e 39,67\%, no nível $20-30 \mathrm{~cm}(48)$.

\begin{tabular}{ccc}
\hline Nível & Quantidade & $\%$ \\
\hline $0-10 \mathrm{~cm}$ & 353 & 15,39 \\
$10-20 \mathrm{~cm}$ & 947 & 41,3 \\
$20-30 \mathrm{~cm}$ & 712 & 31,06 \\
$30-40 \mathrm{~cm}$ & 206 & 8,98 \\
$40-50 \mathrm{~cm}$ & 33 & 1,44 \\
$50-60 \mathrm{~cm}$ & 34 & 1,48 \\
$60-70 \mathrm{~cm}$ & 8 & 0,35
\end{tabular}

Tabela 6: Quantidade e densidade de material cerâmico por nível na malha 30×30m

$\mathrm{Na}$ Sondagem S49 E54 ocorre pela segunda vez a Terra Preta Arqueológica. Neste ponto, como realizado em N4 E22, além da escavação, houve um trabalho de descrição e coleta de solos no perfil SE da sondagem. 


\begin{tabular}{ccc}
\hline & Lítico & Ceramica \\
\hline $\mathbf{0 - 1 0} \mathbf{~ c m}$ & 15 & 104 \\
$\mathbf{1 0 - 2 0} \mathbf{~ c m}$ & 25 & 172 \\
$\mathbf{2 0 - 3 0} \mathbf{~ c m}$ & 18 & 129 \\
$\mathbf{3 0 - 4 0} \mathbf{~ c m}$ & 5 & 105 \\
$\mathbf{4 0 - 5 0 ~ c m}$ & 3 & 20 \\
$\mathbf{5 0 - 6 0} \mathbf{~ c m}$ & 8 & 32 \\
$\mathbf{6 0 - 7 0 ~} \mathbf{~ m}$ & 0 & 8
\end{tabular}

Tabela 7: Resultado da escavação da sondagem S49 E54

Nos dois pontos de ocorrência de TPA tradagens realizadas atestam que aparentemente estas feições são elipsoidais, não possuindo grandes dimensões. Estima-se não mais de $20 \mathrm{~m} \times 15 \mathrm{~m}$, e as camadas pretas variaram entre $40-50 \mathrm{~cm}$ de espessura.

É possível observar uma maior ocorrência de cerâmica nas sondagens N1 E18, N18 E17 e S49 E54.(25\% em relação ao total geral da escavação). Estas apresentaram uma camada de TPA chegando a $45 \mathrm{~cm}$ de espessura. Quanto ao material lítico, isto também ocorreu, com uma significativa freqüência de $81,43 \%$ do total nas sondagens N1 E18 (27,27\%) e S48 E54 (61,16\%).
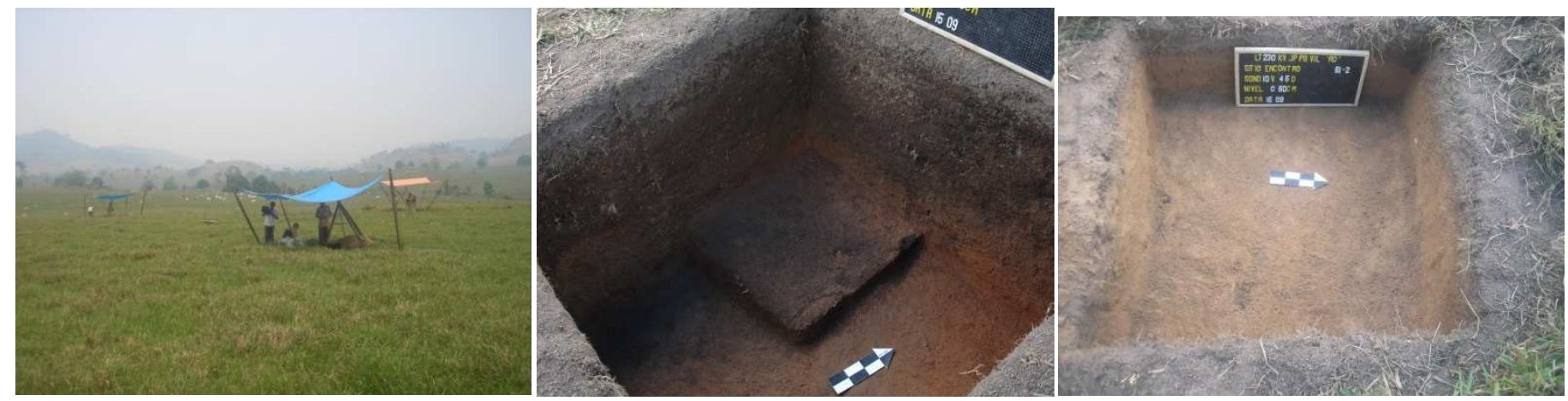

Imagem 31: a esquerda, escavação da malha 30×30m, no centro, sondagem S49 E54, e a direta, $35 \mathrm{~S} / 31 \mathrm{~W}$, esta mais afastada nas ocorrências de TPA e com pouca presença de material arqueológico. 
Imagem 32 densidade de materlai $30 \times 30$

Planimetria, topografia e dispersão cerâmica resultados da segunda fase.

Fonte: Scientia (2006), arte: Wanderson Esquerdo. 


\subsection{CerÂMICA}

\subsubsection{Análise cerâmica}

A metodologia empregada na análise cerâmica visou em criar categorias, com base nos atributos, que pudessem refletir escolhas realizadas nas diferentes etapas do processo de manufatura do utensílio cerâmico. Foram elencados atributos tecnológicos, morfológicos e decorativos. A ficha de análise foi baseada em atributos definidos por Shepard (1956), Meggers (1970), Chmyz et alli (1976), Rye (1987), Rice (1987) e Orton et alli (2003).

No total de 44 sondagens escavadas, foram recuperados 7618 fragmentos. Todo o material escavado foi lavado, quantificado, triado e pesado. A triagem consistiu na escolha daqueles fragmentos que poderiam dar mais informações em relação a outros durante a análise. Os critérios para a seleção foram: categoria $^{22}$, presença de tratamento de superfície, presença de decoração e marcas $^{23}$. O material selecionado totalizou 1614 fragmentos $^{24}$, denominado material diagnóstico que foi então ser submetido a ficha de análise. (vide Anexo 1)

A partir do material selecionado, buscamos acessar informações que possam auxiliar na caracterização desta indústria cerâmica, assim como produzir dados suficientes para permitir que possibilite a comparação com outros sítios da região.

O primeiro atributo analisado no material foi a categoria, uma série de atributos que indicam aspectos da morfologia do fragmento. Em seguida é determinada a técnica de manufatura, que basicamente consiste no acordelado e modelado. Foi constatada também a co-existência de duas técnicas em um mesmo fragmento.

\footnotetext{
${ }^{22}$ Relacionados a morfologia do fragmento. Em suma, seria tudo aquilo que é diferente de parede e está contemplado no item Categoria da ficha de análise

${ }^{23}$ A partir das variáveis do item 'marcas' da ficha de análise

${ }^{24}$ Correspondendo a $20,4 \%$ do total da coleção.
} 
A seguir são analisados os atributos relacionados ao antiplástico. Primeiramente são identificados seu tipo, que no caso do sítio, como veremos, era composta por minerais em sua totalidade, ou combinados em alguns casos, com chamote (cerâmica moída), carvão ou vegetais. É verdade que o antiplástico mineral pode ser encontrado naturalmente na argila, não sendo necessariamente inserido propositalmente, e devido a este fato, buscamos levantar questões um pouco além do tipo de antiplástico. Segundo Orton et alli (2003) a fabricação de um utensílio cerâmico (preparação da argila, forma, espessura das paredes, decoração, a relação entre o tempo de secagem do pote antes da queima e as técnicas de cocção possíveis) e as propriedades tecnológicas de um pote pronto (Porosidade, resistência física e térmica) dependem em grande parte do caráter da mistura da argila original com outros componentes antiplásticos - ou a própria eliminação destes componentes que podem estar naturalmente na matéria-prima.

O autor ainda sustenta que quase toda a argila requer algum tipo de preparação antes de ser empregada na fabricação da cerâmica. A preparação da argila entra em duas categorias. A primeira se relaciona a limpeza, a extração de materiais não desejados, como raízes por exemplo. Em segundo lugar pode ser necessária a modificação das propriedades do material. 0 objetivo é obter um produto (esperado quais as propriedades sejam previsíveis, controladas e adequadas) a partir das matérias-primas que variam, para 0 processo montagem, secagem e cocção que se deseja empregar. As propriedades desejadas para o produto final já cozido, como por exemplo as características térmicas(efetividade e resistência), dureza, porosidade, podem exigir certas preparações específicas.(idem)

Dentro da análise do antiplástico procuramos utilizar parâmetros que pudessem chegar a dar informações, além do tipo de antiplástico presente, a proporção e a sua homogeneidade, buscando identificar se houveram determinadas escolhas feitas pelo artesão durante a produção dos artefatos cerâmicos. Os atributos criados foram à freqüência, e a forma (ordenação).

O objetivo pretendemos com o atributo Freqüência do antiplástico é estimar a proporção de antiplásticos no fragmento. Isto se dá a partir do estabelecimento 
de uma referência gráfica que estima uma porcentagem visual de antiplásticos na pasta. Um gabarito, a partir de Mathew,et. al. (1991) serviu de base para as variáveis de análise:

\section{Frequencia}
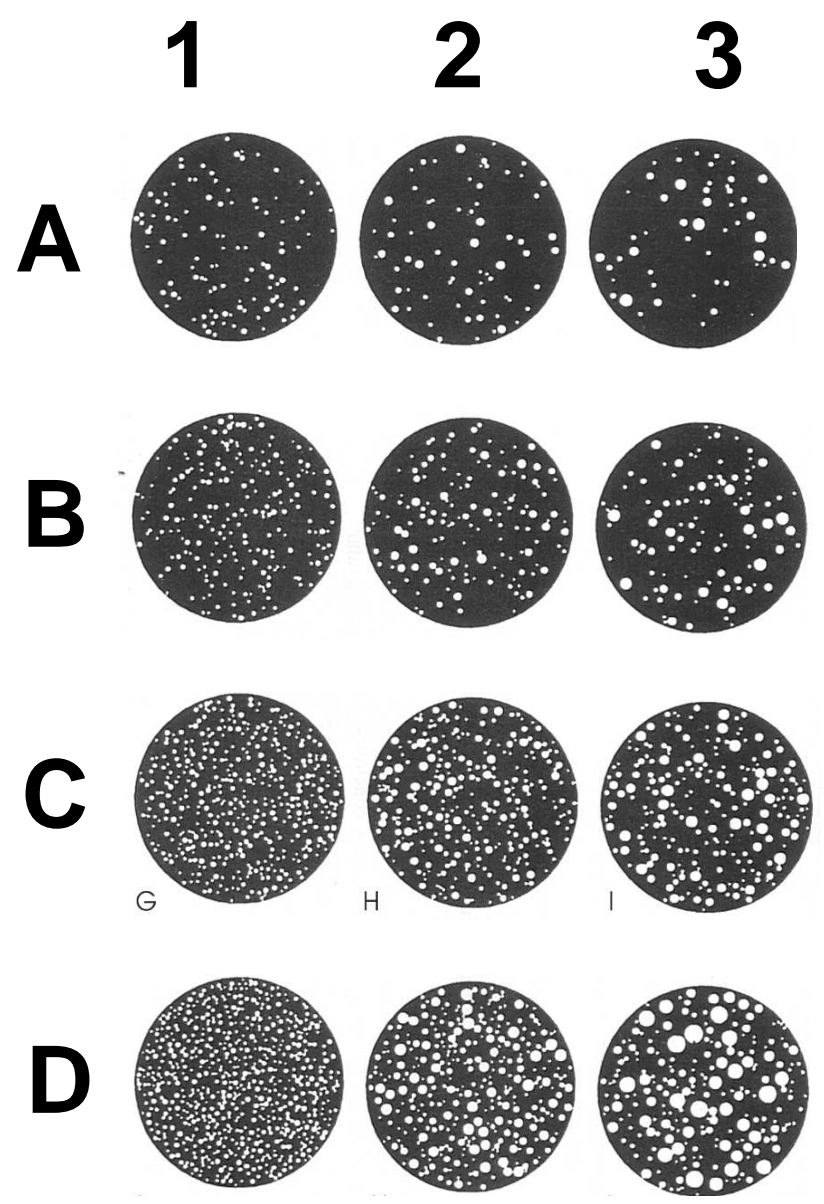

A1: $5 \%, 0,5$ a $1 \mathrm{~mm}$; A2: $5 \%, 0,5$ a $2 \mathrm{~mm}$; A3: $5 \%, 0,5$ a $3 \mathrm{~mm}$; B1: $10 \%, 0,5$ a $1 \mathrm{~mm}$; B2: $10 \%, 0,5$ a $2 \mathrm{~mm}$; B3: $10 \%, 0,5$ a $3 \mathrm{~mm} ; \mathbf{C 1}: 20 \%, 0,5$ a $1 \mathrm{~mm}$; C2: $20 \%, 0,5$ a $2 \mathrm{~mm}$; C3: 20\%, 0,5 a 3mm; D1: 30\%, 0,5 a 1mm; D2: 30\%, 0,5 a 2mm; D3: 30\%, 0,5 a 3mm.

Imagem 33: Mathew et al. (1991) A combinação entre letras e números gerou 12 variáveis para o atributo.

As colunas $(1,2,3)$ indicam a proporção de elementos $(10 \%, 20 \%, 30 \%)$, enquanto as linhas(A, B, C, D) a variação de suas dimensões $(1 \mathrm{~mm}, 2 \mathrm{~mm}$, $3 \mathrm{~mm}$ ). Contudo, os dados da análise não buscam compreender as dimensões exatas dos componentes antiplásticos, mas sim ter uma aproximação visual de sua proporção na pasta. Nota-se que existem diferenças entre os tipos dos 
extremos das tabelas (A1 e C3). Esta diferença, se observável, pretende contribuir com a caracterização da variabilidade das pastas ${ }^{25}$ cerâmicas utilizadas no sítio. Buscamos observar, por exemplo, se ocorreu a padronização no uso de determinadas características da argila, pois isto poderia indicar escolhas culturais.

Outro atributo que auxiliou foi à ordenação do antiplástico, servindo para auxiliar no entendimento dos dados do item anterior. Também se pretende ter uma idéia da distribuição, da proporção entre os antiplásticos, esta variável indicaria a homogeneidade ou não de suas dimensões. Os mais ordenados teriam todos os grãos de um mesmo tamanho, ao contrário dos mal ordenados. Um gabarito, retirado de Barraclough (1992) serviu de base para a criação das referências desta categoria de análise:

\section{Ordenação}
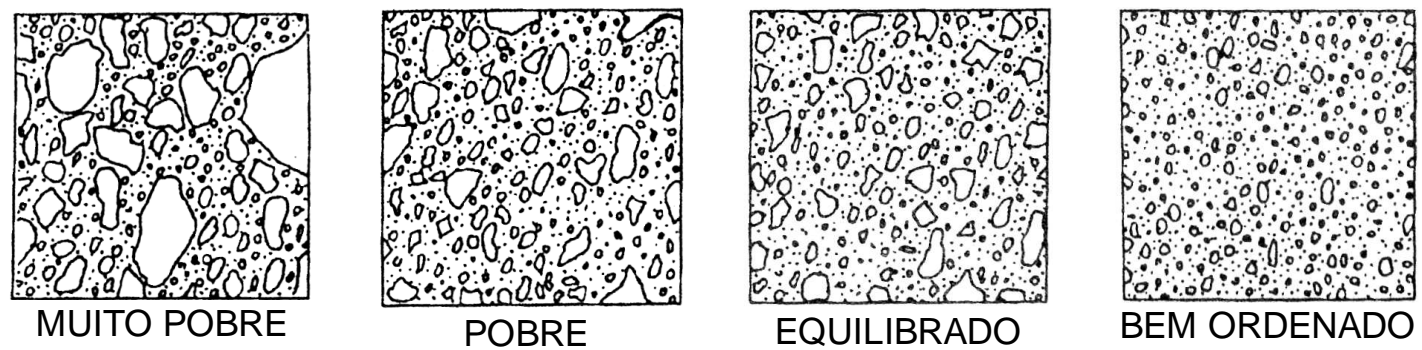

Imagem 34: Barraclough (1992) apud Orton et alli (2003)

Com a posse destes dados, aliados ao item Cor, que será exposto no decorrer do texto, pretende-se realizar inferências quanto a associação entre o uso de determinados antiplásticos e determinadas argilas. Buscamos identificar a recorrência, ou não, de tais associações, pois estas seriam questões importantes relacionadas a possíveis escolhas feitas pelo artesão na produção dos utensílios cerâmicos. As escolhas podem ser entendidas como decisões feitas durante a manufatura dos produtos que determinam as propriedades

\footnotetext{
${ }^{25}$ Foi utilizado um conjunto de atributos buscando identificar os diferentes usos da argila para confecção de artefatos.
} 
formais, a partir dos recursos disponíveis acrescidos dos conhecimentos de seu produtor.

Por outro lado se percebermos a existência de diferenças qualitativas no uso de diferentes antiplásticos, através do mapeamento tanto de seus usos quanto de sua disponibilidade, podemos mapear as propriedades de escolhas relacionadas a certas características de performance (cf. Schiffer e Skibo, 1997) valorizadas por cada grupo ao longo do tempo. Através das escolhas técnicas, estas poderiam constituir um jogo de interações das capacidades específicas que o artefato possui, ou seja, aptidões de comportamento que 0 artefato deve possuir para cumprir sua função em atividade específica.

Concordamos com Machado $(2005,2007)$ ao avaliar que é interessante realçar a importância caracterização do antiplástico como indicador de uma série de escolhas tecnológicas decorrentes de etapas da elaboração de um utensílio, ao invés de utilizarmos como uma espécie de fóssil guia de tradições cerâmicas.

A queima é avaliada em seguida, sendo classificada completa, em ambientes oxidantes ou redutores, e incompleta.

Também procuramos avaliar a cor dos fragmentos. As diferenciações entre as cores corresponderam a observações macroscópicas, que podem também refletir variações do processo de queima, mas que todavia, apresentaram-se relevantes no decorrer da análise por serem capazes de produzir informação sobre padrões recorrentes de associações de antiplásticos específicos em alguns casos, com conjuntos de potes específicos, por exemplo. Este é um fato já observado por Machado $(2005,2006)$ e Chirinos (2006) em cerâmicas da Amazônia central. Foi nesse sentido que o item Cor foi criado, que aliados aos itens sobre o antiplástico, buscam auxiliar na criação de dados qualitativos sobre a pasta cerâmica. Dentro do processo de elaboração de um utensílio cerâmico a escolha da argila é uma etapa importante. Em alguns casos, determinados utensílios são produzidos somente com argilas específicas. (Orton, et al 1997). As observações macroscópicas das diferentes colorações que os fragmentos possuem, podem auxiliar na criação de hipóteses em relação ao fato mencionado. 
Para a determinação da cor foram criadas coleções de comparação com fragmentos do sítio, contendo exemplos das diferentes tonalidades que cada cor possui. A escolha dos tipos de Cor foi realizada a partir dos cromas da tabela de Munsell, e com influência do senso comum da percepção dos pesquisadores envolvidos na análise. Considerou-se para a comparação das cores, a face externa dos fragmentos.

Em seguida, foi feita a classificação dos tratamentos de superfície. Os processos de acabamento dos potes podem ocorrem tanto antes quanto após a cocção, e é diretamente influenciado pela proposta da função do artefato. Analisamos os processos de alisamento, polimento e barbotina ${ }^{26}$, aplicados tanto na face interna como externa dos fragmentos.

As bordas foram classificadas a partir de sua morfologia, inclinação e espessura. Os atributos adotados são os mesmos indicados pela TERMINOLOGIA (Chmyz,1976). Quanto à morfologia, a borda poderia ser classificada como direta, extrovertida, introvertida. A inclinação é dividida, inclinada internamente ou inclinada externamente. A espessura é classificada como normal, expandida, reforçada internamente, reforçada externamente, dobrada ou contraída.

Junto com a borda é analisado também o lábio, sendo identificado como arredondado, plano, apontado ou biselado, e tendo a sua espessura, em milímetros, mensurada. Quando possível obtiveram-se dados sobre o diâmetro da boca, com o auxilio do ábaco.

A análise ainda realiza a observação dos aspectos decorativos dos fragmentos, divididos entre plásticos e pintados. As técnicas de tratamento plástico encontradas no sítio são diversas: como por exemplo: o roletado, inciso, corrugado e o ungulado. A cerâmica pintada envolve a aplicação de pigmentos

\footnotetext{
${ }^{26}$ Para a classificação, entendemos a barbotina como uma mistura fluida de pasta cerâmica, com a mesma coloração do fragmento, diferente do que foi classificado como engobo, um banho com uma mistura fluída de pasta cerâmica, com pigmentação, de cor diferente do fragmento. Rye (1987) comenta sua função impermeabilizante, mas a atribui uma função decorativa, como uma camada que se superpõe à superfície de uma peça a fim de modificar, depois da queima, a cor e o aspecto da superfície. Este item foi avaliado em decoração.
} 
diretamente na superfície, ou sob camada de engobo, tanto na face interna, como externa dos cacos.

O processo de apreciação incluiu também o registro gráfico, que consistiu no desenho dos perfis de bordas, indicando a inclinação, espessura, tratamento de superfície e o possível diâmetro de abertura. Devido ao fato de não haver a ocorrência de fragmentos (ou conjunto de fragmentos agrupados) como bordas, bojos e bases, que fornecessem dados quanto a morfologia dos potes, não foram realizadas reconstruções de forma. Também desenhamos os perfis as bases, indicando a inclinação. O processo de registro concluiu-se com a fotografia dos tipos selecionados.

\subsubsection{REsUltados}

\subsubsection{Categoria}

Do total de 44 sondagens escavadas, foram recuperados 7618 fragmentos cerâmicos. Para a análise foram definidos 1614 fragmentos diagnósticos, a partir dos parâmetros explicitados anteriormente, sendo divididos a partir de sua categoria em (77\%), bordas (19,82\%) e outras partes do pote, como: base, ombros, formas conjugadas, carenas, bolotas de argila, apliques, que representam 3,18\% dos fragmentos. (Gráfico 1)

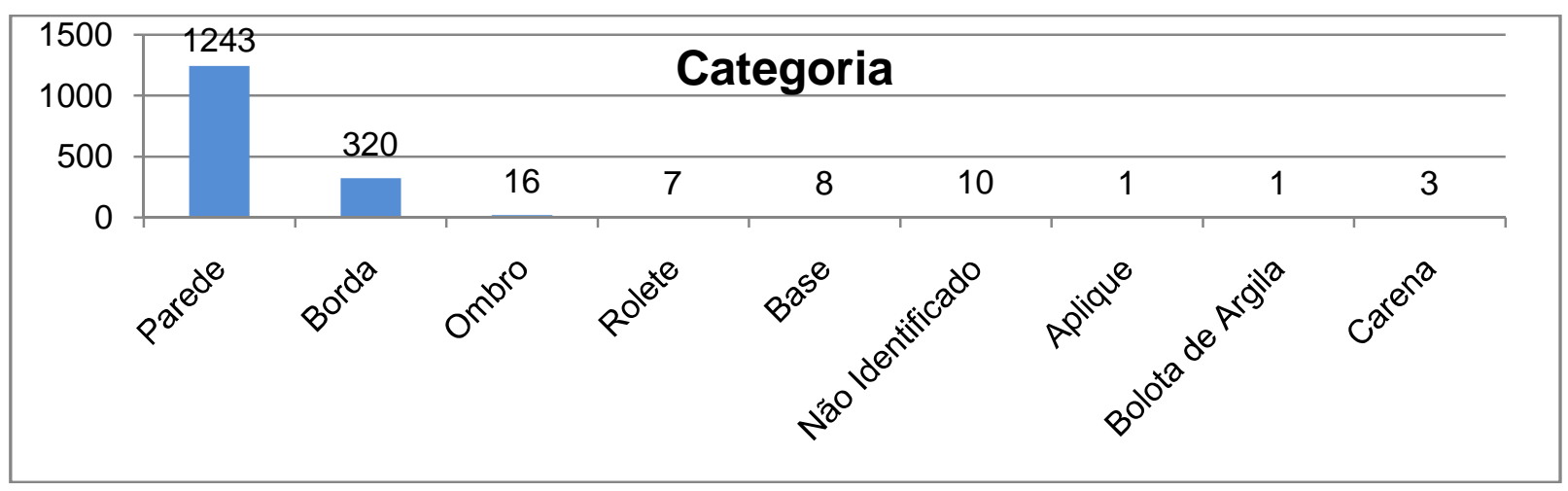

Gráfico 1 : Resultado da triagem 


\subsubsection{Técnicas de manufatura}

$\mathrm{Na}$ técnica de manufatura, o tipo predominante foi o acordelado - sobreposição de roletes de argila, em forma circular, para dar forma as paredes de um pote. Entretanto, na maior parte dos fragmentos, não pode ser reconhecida a técnica de manufatura, por não apresentaram quebras, ou outros sinais suficientemente reconhecíveis. (Gráfico 2) Esta técnica (acordelamento) foi utilizada inclusive na elaboração das bases dos artefatos. Em um único fragmento (bolota de argila) foi constada do modelado.

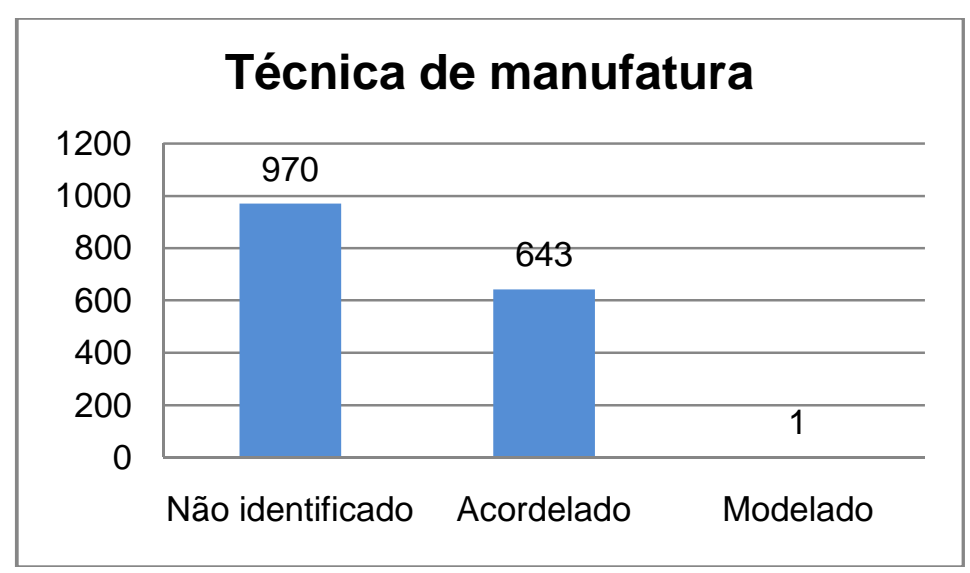

Gráfico 2: Técnica de manufatura

\subsubsection{Antiplástico}

$\mathrm{Na}$ classificação dos antiplásticos foi apontado um predomínio do uso de antiplástico mineral, podendo ser caracterizado como areia. (Gráfico 3). Os minerais identificados - quartzo, feldspato, mica e dois tipos de hematita estavam sempre associados, havendo uma variação entre a presença e ausência de um dos tipos de hematita e mica (Gráfico 4). Houve poucos casos $(2,54 \%)$ em que foram identificados outros elementos junto com o antiplástico mineral, como: chamote ${ }^{27}$, carvão e vegetal ${ }^{28}$.

\footnotetext{
${ }^{27}$ Caco de cerâmica moída.

${ }^{28}$ Estes vegetais foram identificados no interior da pasta. Tratam-se de minúsculos vestígios, parecendo pequenos galhos. Não ocorreu cariapé.
} 


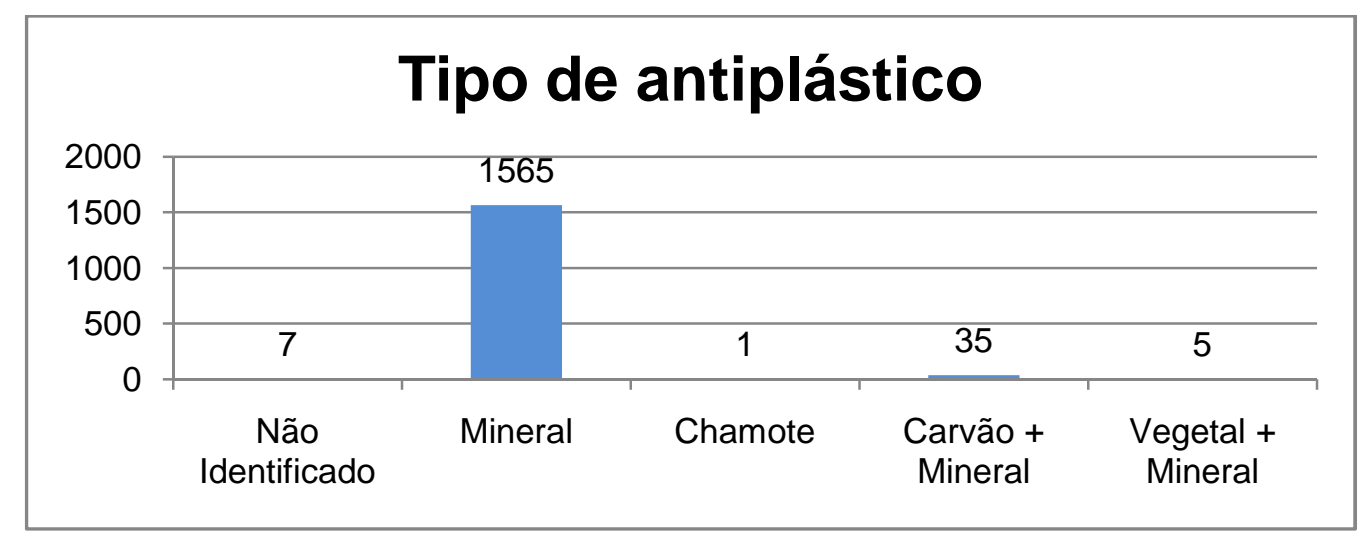

Gráfico 3: Tipo de Antiplástico identificado

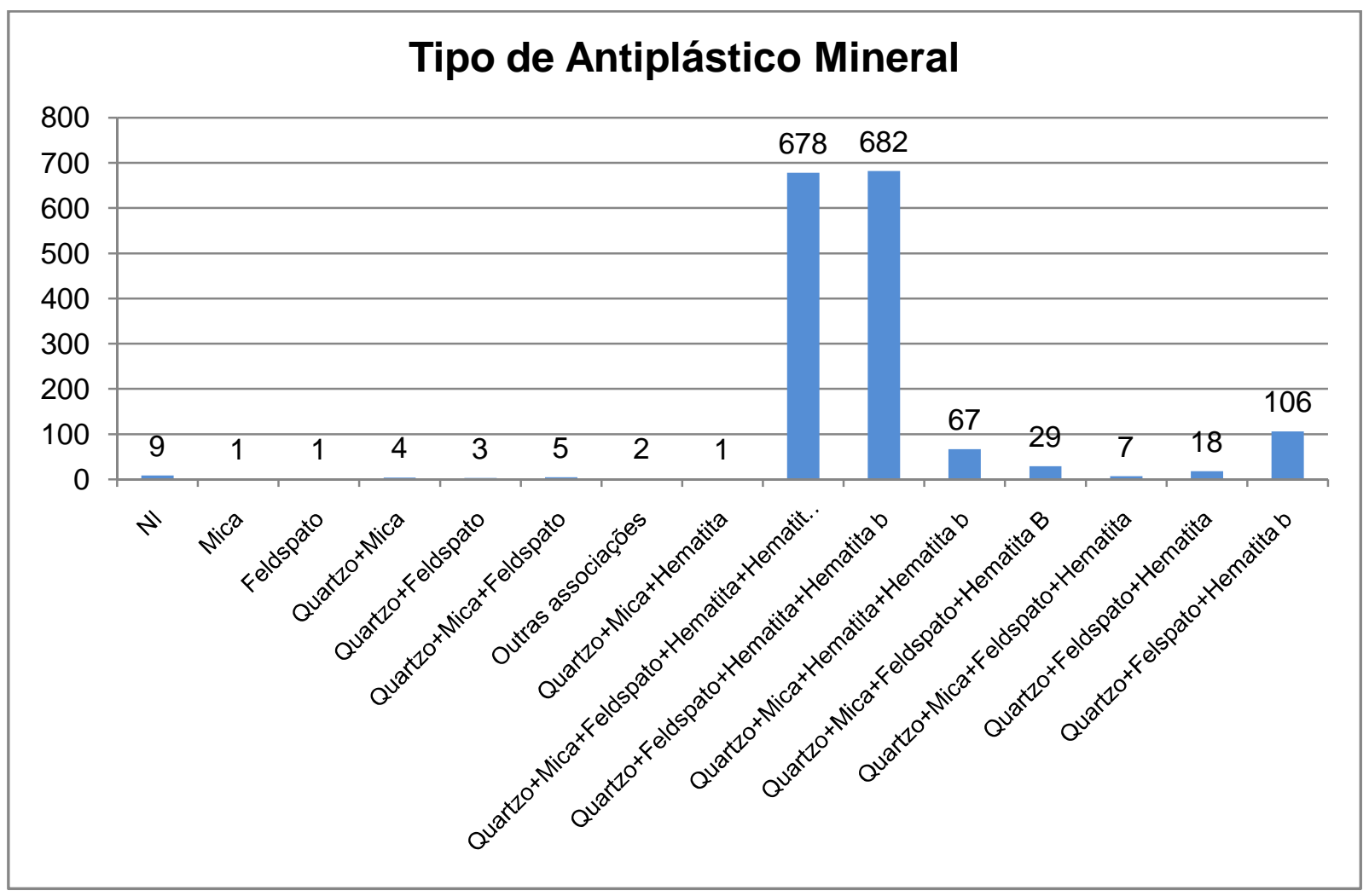

Gráfico 4: Tipos de antiplástico mineral

Freqüência, ordenação e dimensões do antiplástico

A avaliação da freqüência de antiplásticos no fragmento, é feita a partir de uma referência gráfica, com as variáveis estabelecidas a partir da relação das 
colunas (1,2,3), que indicam a dimensão dos elementos $(0,5$ a $1 \mathrm{~mm}, 0,5$ a $2 \mathrm{~mm}$, 0,5 a 3mm), com as linhas(A, B, C, D), que indicam a variação de sua proporção $(5 \%, 10 \%, 20 \%, 30 \%)^{29}$.

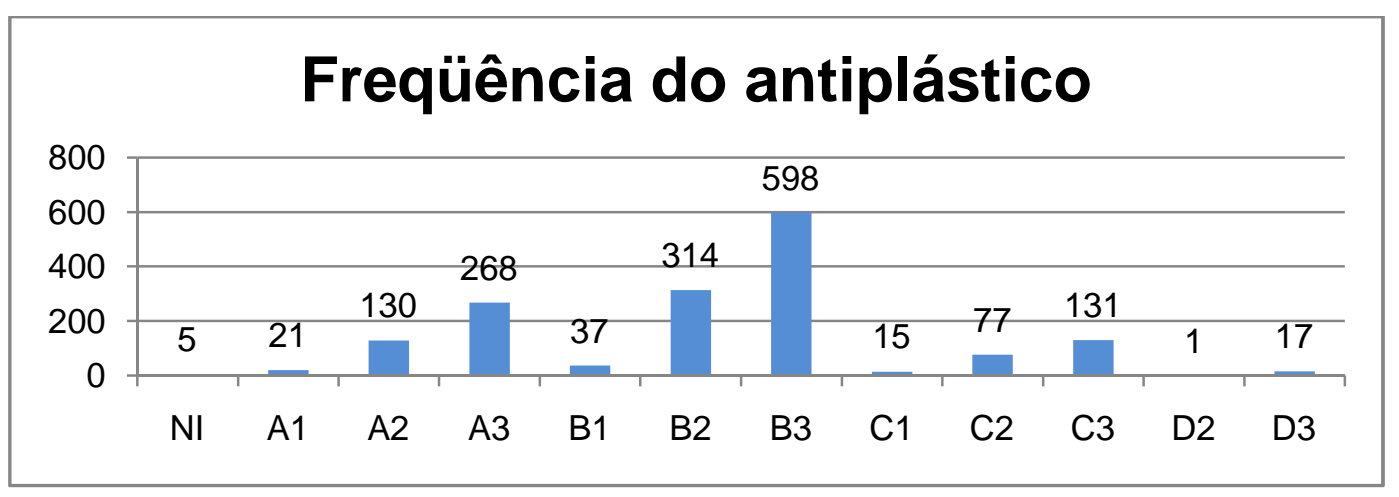

Gráfico 5: Freqüência do antiplástico

Os tipos mais freqüentes (A3, B2 E B3) somam 73,2\%, e têm como com característica, em comum o caráter heterogêneo da distribuição de antiplástico na pasta $(0,5 \mathrm{~mm}$ a $2 \mathrm{~mm}$ e 0,5 a $3 \mathrm{~mm})$ e a proporção de $10 \%$. Esta proporção, como observado no sítio, correspondem como um equilíbrio, entre os valores de menor e maior quantidade de antiplástico encontrados na pasta. Os tipos $A 1, A 2, B 1, C 1$, considerados mais finos, com menor teor de antiplástico e com componentes mais homogêneos, representam $12,9 \%$ dos casos. Os tipos que atingem maior quantidade antiplástico no fragmento foram agrupados, em C2, C3, D2, D3, e correspondem a $13,9 \%$ dos casos.

Os resultados da freqüência podem ser relacionados com o item seguinte. A ordenação também indicou que predominam os tipos heterogêneos em relação as dimensões do antiplástico. Os tipos Muito pobre e Pobre são encontrados em grande quantidade, em $87,7 \%$ dos casos. Já tipos mais homogêneos (Equilibrado, bem e muito bem ordenado) ocorrem em $12,3 \%$ dos casos.

${ }^{29}$ Os tipos resultantes, que podem ser visualizados na página 86 , imagem 33 , foram: A1: $5 \%, 0,5$ a 1mm; A2: 5\%, 0,5 a 2mm; A3: 5\%,0,5 a 3mm; B1: 10\%, ; B2: 10\%, 0,5 a 2mm; B3: $10 \%$, 0,5 a 3mm; C1: 20\%,0,5 a 1mm; C2: 20\%, 0,5 a 2mm; C3: 20\%, 0,5 a 3mm; D1: 30\%, 0,5 a 1mm; D2: 30\%, 0,5 a 2mm; D3: 30\%, 0,5 a 3mm. 


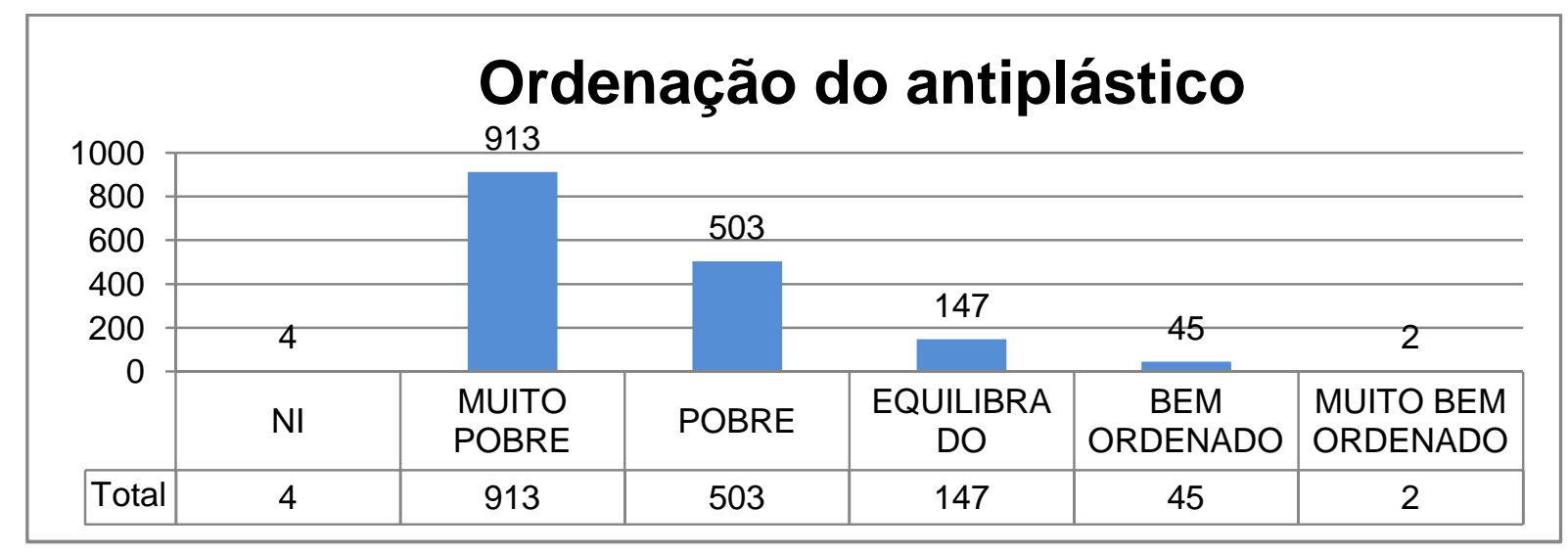

Gráfico 6: Ordenação do antiplástico

Durante a análise do antiplástico também foi mensurado o maior antiplástico presente na superfície da quebra. Os tipos elencados nesta categoria determinaram medidas divididas entre menor que $1 \mathrm{~mm}$, menor ou igual a $1 \mathrm{~mm}$, menor que $3 \mathrm{~mm}$, menor igual a $3 \mathrm{~mm}$, menor que $5 \mathrm{~mm}$ e maior ou igual a $5 \mathrm{~mm}$. (Gráfico 7)

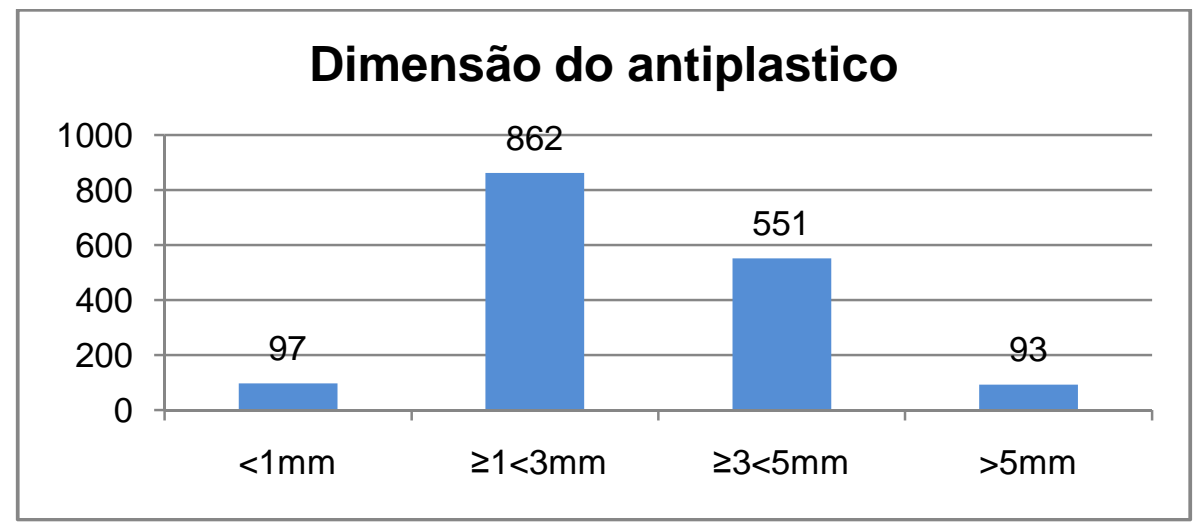

Gráfico 7 : dimensão do antiplástico

A variação do antiplástico, praticamente não ocorre, predominando os elementos de origem mineral. Contudo, em relação a proporção do antiplástico, como constatado, a variedade de tipos é grande. Ocorrem fragmentos com componentes muito pequenos, homogêneos e pouco presente na pasta, assim como casos com muito antiplástico na pasta e este com dimensões muito variadas. A variação destes elementos pode ser resultado de determinadas escolhas que possam ter acontecido, e que colocam o antiplástico, como um passo decisivo durante os processos de manufatura cerâmica. A relação destes dados, com o outros como Cor da pasta e espessura, vão ser 
fundamentais para a caracterização das pastas cerâmicas presentes no sitio, item desenvolvido após a exposição dos resultados.

\subsubsection{Queima}

O processo de queima da argila pode definir e alterar características como: cor, textura e dureza do utensílio. Contudo estes procedimentos nem sempre são bem entendidos. As variações tipologicamente determinadas (queima completa: oxidante, redutora e incompleta) podem coexistir em uma mesma situação, no mesmo pote, refletindo situações difíceis de serem acessadas arqueologicamente a partir de fragmentos, como por exemplo: 0 posicionamento do vasilhame na hora da queima, a quantidade de vasos cozidos ao mesmo tempo, o tipo de fogueira, tipo de combustível, a temperatura alcançada, etc. Além disso, ocorrem as alterações pelo uso e também as pós-deposicionais, e mais diferentes processos podem criar condições iguais identificadas pelo pesquisador.

Muitos fragmentos apresentam variações na coloração da pasta, indicando tanto queima em ambientes oxidantes, quanto redutores. $\mathrm{Na}$ maioria dos casos ocorreu uma queima completa $(85,1 \%)$, em ambientes redutores e oxidantes, e a queima incompleta representou 14,9\%. (Gráfico 8)

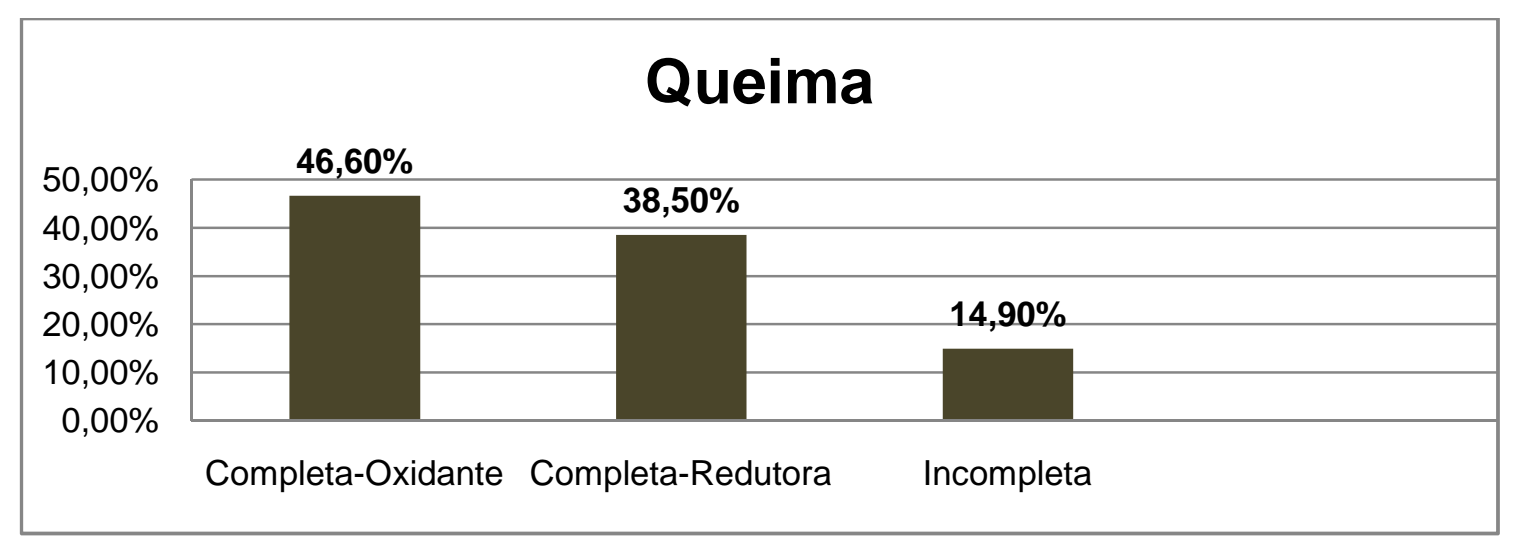

Gráfico 8: Tipos de queima identificados 


\subsubsection{Cor da pasta}

Inicialmente as diferentes cores identificadas foram: Amarelo, Laranja, Marrom A (claro), Marrom B (escuro), Vermelho e Preto. (Gráfico 9)

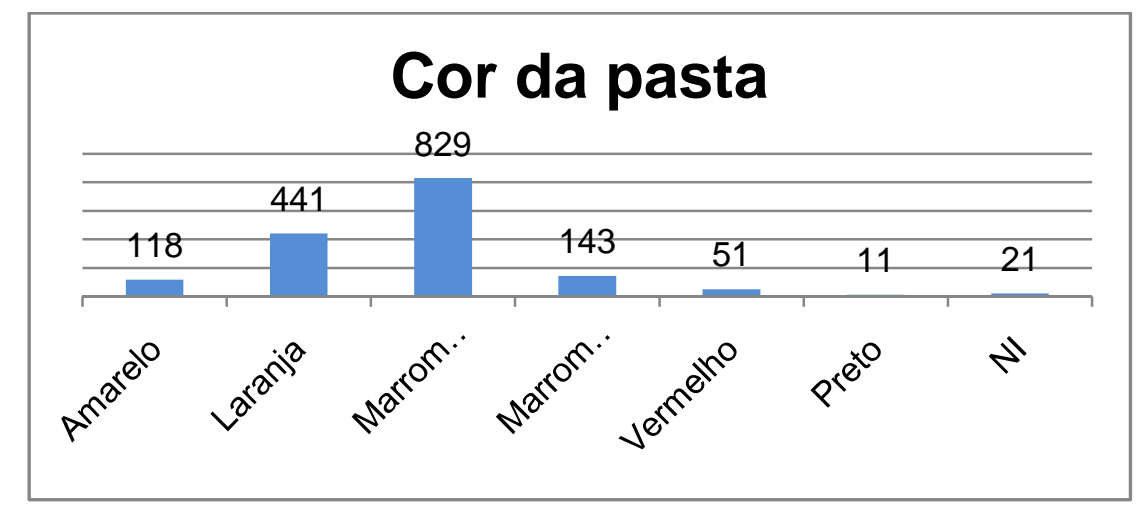

Gráfico 9: Quantidade de fragmentos por cor da pasta identificados

Interpretamos que as tonalidades de marrom $A$ e $B$, não necessariamente poderiam implicar uma mudança de argila, mas sim refletir os processos de queima que alteram a cor da cerâmica. Portanto, consideramos as cores Marrom A e Marrom B, como uma só variável. A cor preta também não foi considerada, já que esta pode ser resultado de diferentes processos, como queima de manufatura, alterações por uso ou processos erosivos. Logo o item cor ficou definido como abaixo podemos acompanhar no Gráfico 10:

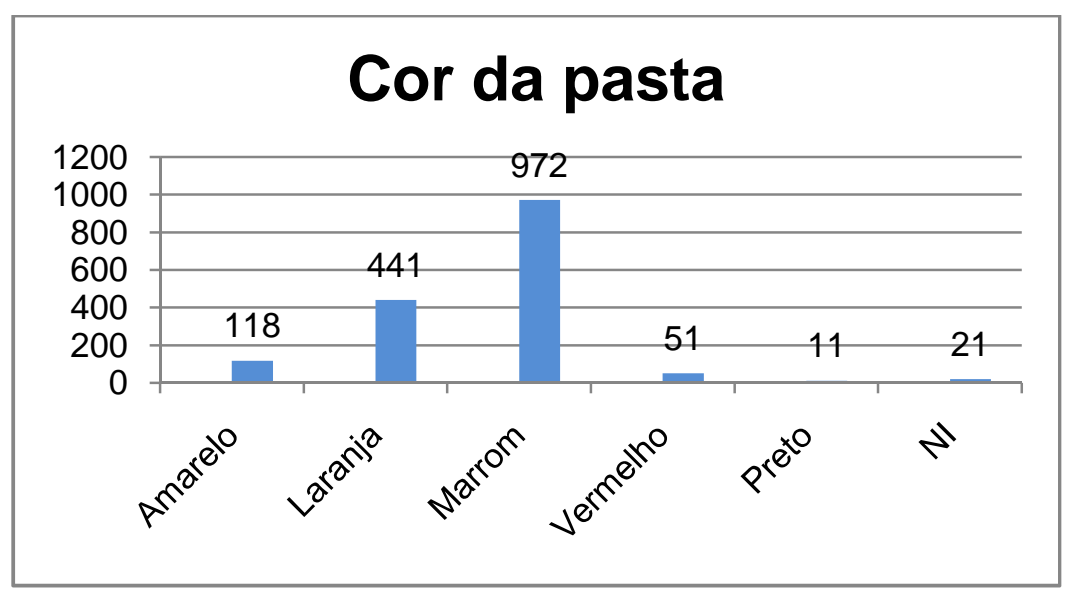

Gráfico 10: Resultado da quantidade de cerâmica por tipo de cor. 
A pasta de cor marrom foi predominante $(61,2 \%)$, seguindo da laranja $(28,2 \%)$, amarela $(\% 7,4)$ e vermelha $(3,2 \%)$. A análise do comportamento da variabilidade de cada cor, em relação a diferentes atributos, como freqüência e ordenação do antiplástico, por exemplo, são dados que serão utilizados, visto o objetivo de caracterizarmos os tipos de pasta encontradas no sítio.
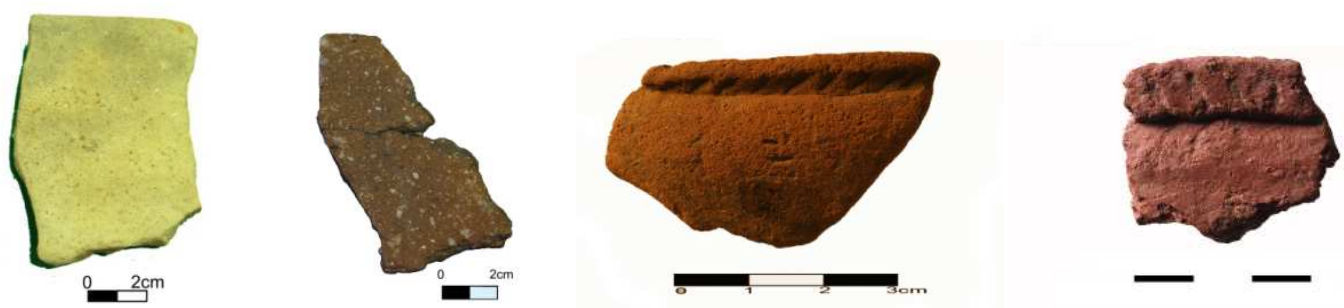

Imagem 35: cores da pasta identificadas, da esquerda para direita, amarelo, marrom, laranja e vermelho.

\subsubsection{Tratamentos de superfície}

A maioria dos fragmentos analisados é do tipo simples, sem decoração plástica ou pintada, apresentando superfícies alisadas (94,5\%). Os processos de alisamento deixaram em alguns casos (90 fragmentos), diferentes tipos de estrias, tanto na face externa, como interna dos fragmentos. Sugerimos que estas diferenças nas superfícies possam ser resultado de diferentes instrumentos utilizados para o alisamento, ou de diferenças no modo de uso destes utensílios - além da própria mão, Rye (1987) sugere outros materiais como: folhas, couro, tecido, cestaria, etc. seriam utilizados para o alisamento.

Em muitos casos, concomitante ao alisamento, ocorre o que caracterizamos como barbotina. Sua identificação foi de determinada pela constatação da presença de uma fina camada que encobria os maiores antiplásticos, por vezes expostos na superfície do fragmento, além de preencher imperfeições quando analisado o perfil da quebre na lupa binocular. Brochado e La Salvia (1989, p.18) consideram a barbotina como um "revestimento superficial, proveniente de um caldo de argila em suspensão na água, aplicado à superfície cerâmica antes da queima". 
Sua ocorrência é popular, foi identificada em 789 fragmentos, representando 48,9\% da coleção analisada. Em diversos fragmentos não puderam ser identificados vestígios da barbotina devido ao grau de erosão do material. A variação de sua localização, face interna, externa ou ambas, pode ser relacionada também com o estado de conservação, em grande parte erodido.

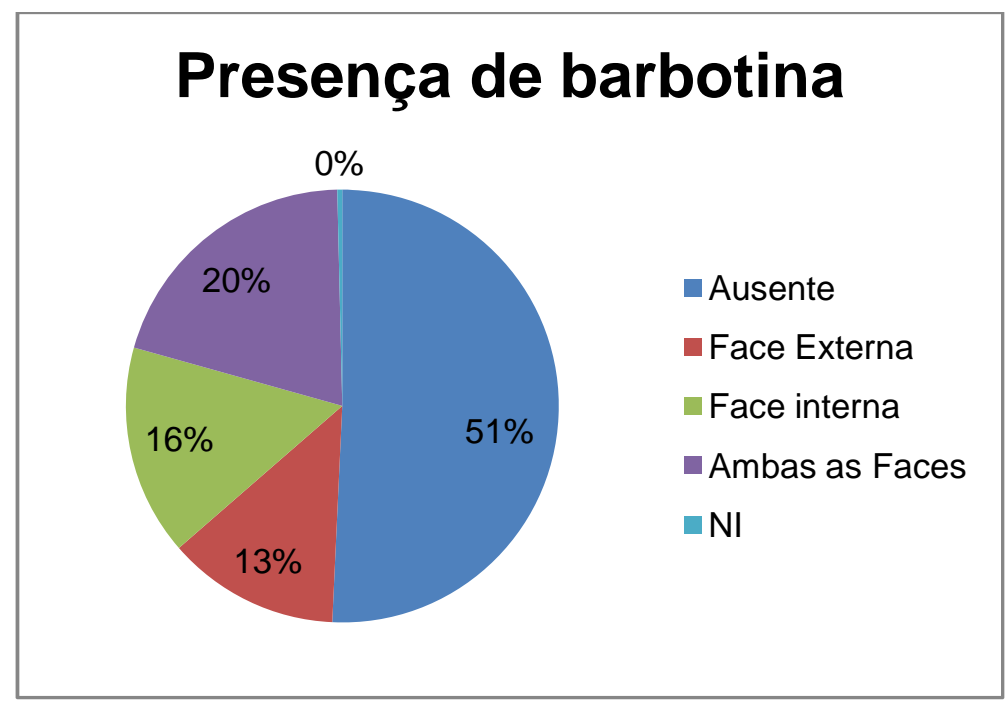

Gráfico 11: Presença de barbotina

Em três casos foi interessante constatar camadas mais espessas da barbotina, conforme o exemplo do fragmento Em-924. Ambos os fragmentos correspondem a partes próximas a base, e podem indicar aspectos relacionados à técnica de aplicação da barbotina nos utensílios.
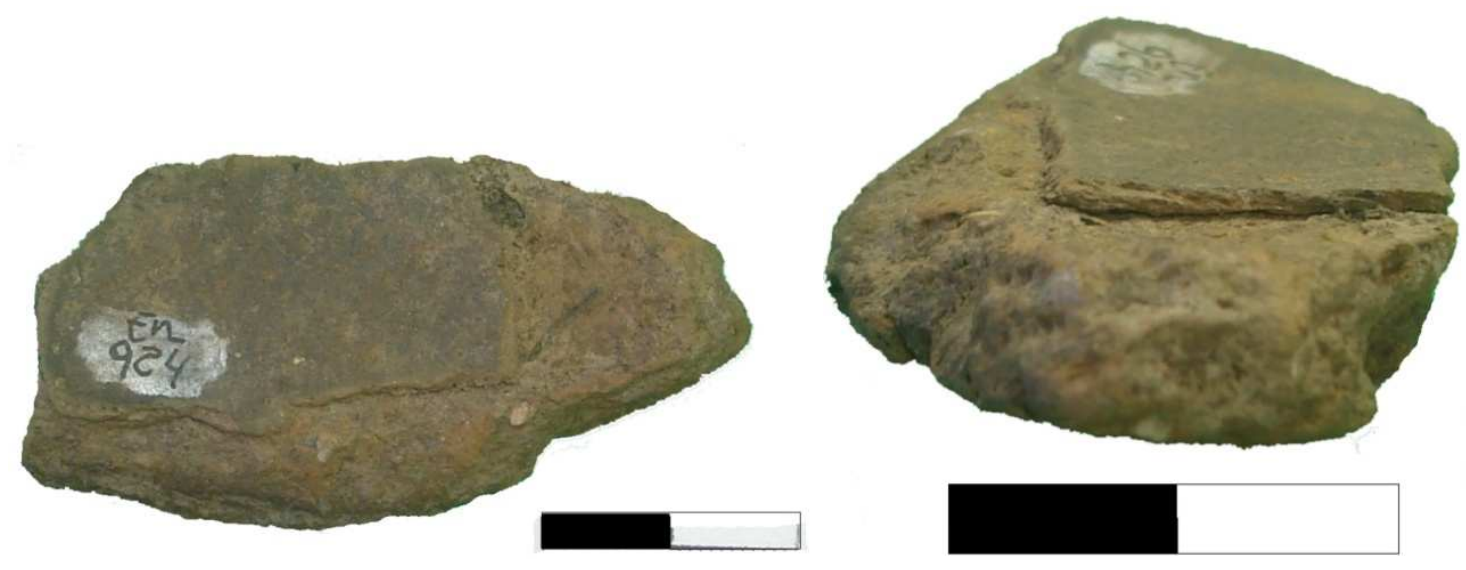

Imagem 36: fragmento Em-924 em diferentes perspectivas. 
Segundo Rye (1987) existem diversas técnicas para a aplicação, que acabam formando características especificas, em relação ao tipo de material utilizado, método de aplicação, queima e os tratamentos de superfície após a queima. As três mais recorrentes consistem em: 1) mergulhar o artefato em um tanque com a suspensão; 2) Jogar o fluido com o auxilio de um artefato atuando como uma espécie de pincel e; 3) Jogar e espalhar o fluído em pequenas quantidades. Em todos os casos este tratamento é aplicado antes da secagem do pote, já que com o utensílio seco, dificilmente a suspensão irá se fixar, além de também reduzir em grande a parte a trincas na parede durante a secagem. (idem)

$\mathrm{O}$ autor ainda aponta que mergulhar $\mathrm{O}$ artefato em uma vasilha com uma suspensão de argila produz um tratamento de superfície mais homogêneo, com melhor performance em relação aos outros.(ibidem). Este pode ser o caso diagnosticado no fragmento En-924, conforme a imagem 36, já que ao secar o pote depois de mergulhado no fluído, provavelmente um excesso de argila poderia acumular nas proximidades inferiores do artefato, conforme observamos.

Outro tratamento de superfície presente, ainda que pouco freqüente, foi 0 polimento, sendo identificado na face interna e externa dos fragmentos, constituindo $1,17 \%$ da coleção. Apesar da amostra reduzida de indivíduos polidos, nota-se, conforme o gráfico, que há uma tendência entre a espessura do fragmento (entre 0,6 e $0,8 \mathrm{~cm}$ ), e a ocorrência do polimento, sempre na face interna, ocorrendo em $94,4 \%$. 

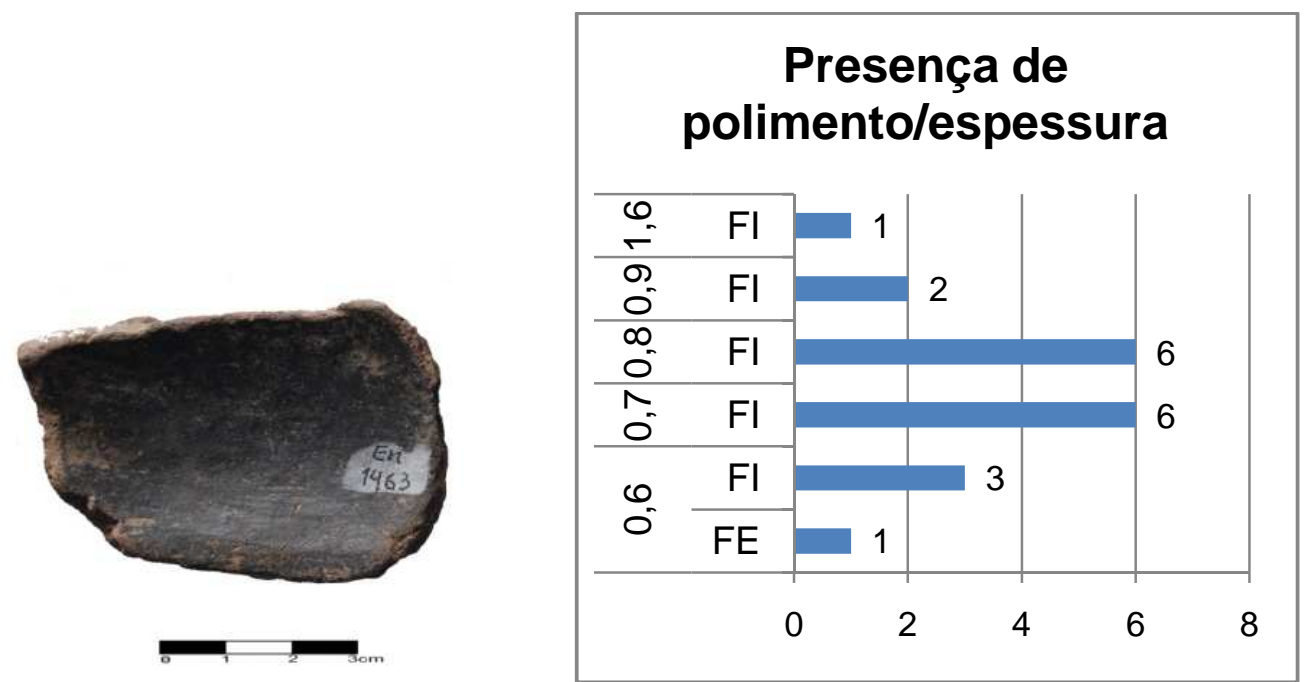

Imagem 37: a esquerda, fragmento En-1463, com polimento na face interna, e a direta, Gráfico com: relação entre a presença de polimento (FE: face externa, FI: face interna) nas espessuras em que ocorreram(Linha vertical, em $\mathrm{cm}$, linha horizontal quantidade de fragmentos).

\subsubsection{Morfologia}

\section{Espessura dos Fragmentos}

No sítio a espessura dos cacos variou de 0,3 a $2 \mathrm{~cm}$, com grande parte se concentrando entre 0,6 e $0,8 \mathrm{~cm}(62 \%)$, havendo poucos indivíduos entre 1 e $1,5 \mathrm{~cm}(6 \%)$ e raríssimos entre 1,6 e $2 \mathrm{~cm}(0,8 \%)$. (Gráfico 12$)$

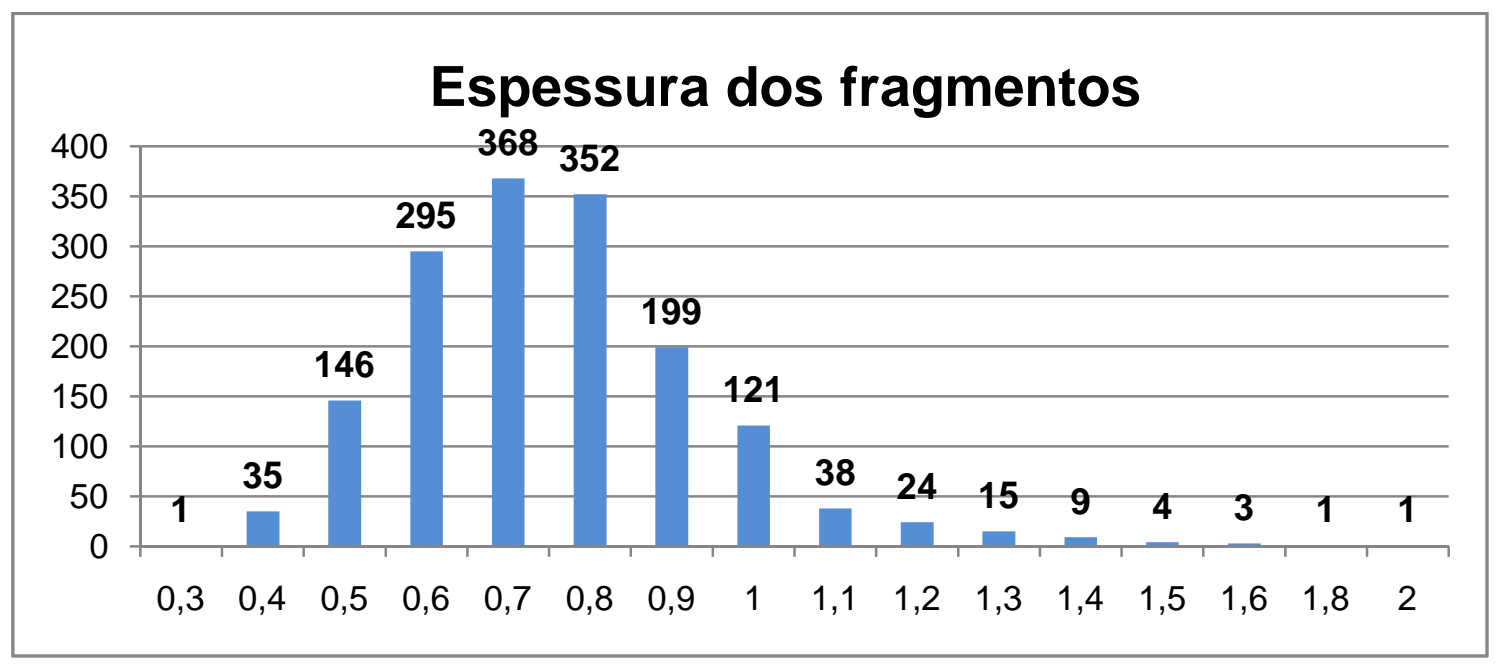

Gráfico 12: espessura dos fragmentos

Segundo Rice (1987), a espessura dos fragmentos pode estar relacionada aos diferentes tipos de função que os utensílios cerâmicos possam ter. Potes com 
paredes mais finas podem conduzir melhor o calor e cozinhar mais rapidamente, enquanto as vasilhas mais grossas podem ser destinadas ao armazenamento e ao processamento de alimentos - por terem maior resistência física e apresentar menos porosidade em relação as mais finas.

\subsubsection{Bordas}

\section{Morfologia das Bordas}

Os termos utilizados para a classificação das bordas foram baseados na Terminologia Brasileira da Cerâmica, organizados em CHMYZ (1976). Além da análise que de todos os fragmentos passam, para as bordas, incluímos atributos relacionados a morfologia, inclinação, espessamento, tipo de lábio e diâmetro de boca. As bordas, quando possível a identificação, foram classificadas morfologicamente como: extrovertidas, tipo predominante com $45 \%$, diretas $(10 \%)$, inclinadas externamente $(27 \%)$, inclinadas internamente $(11 \%)$ e introvertidas $(7 \%)$.

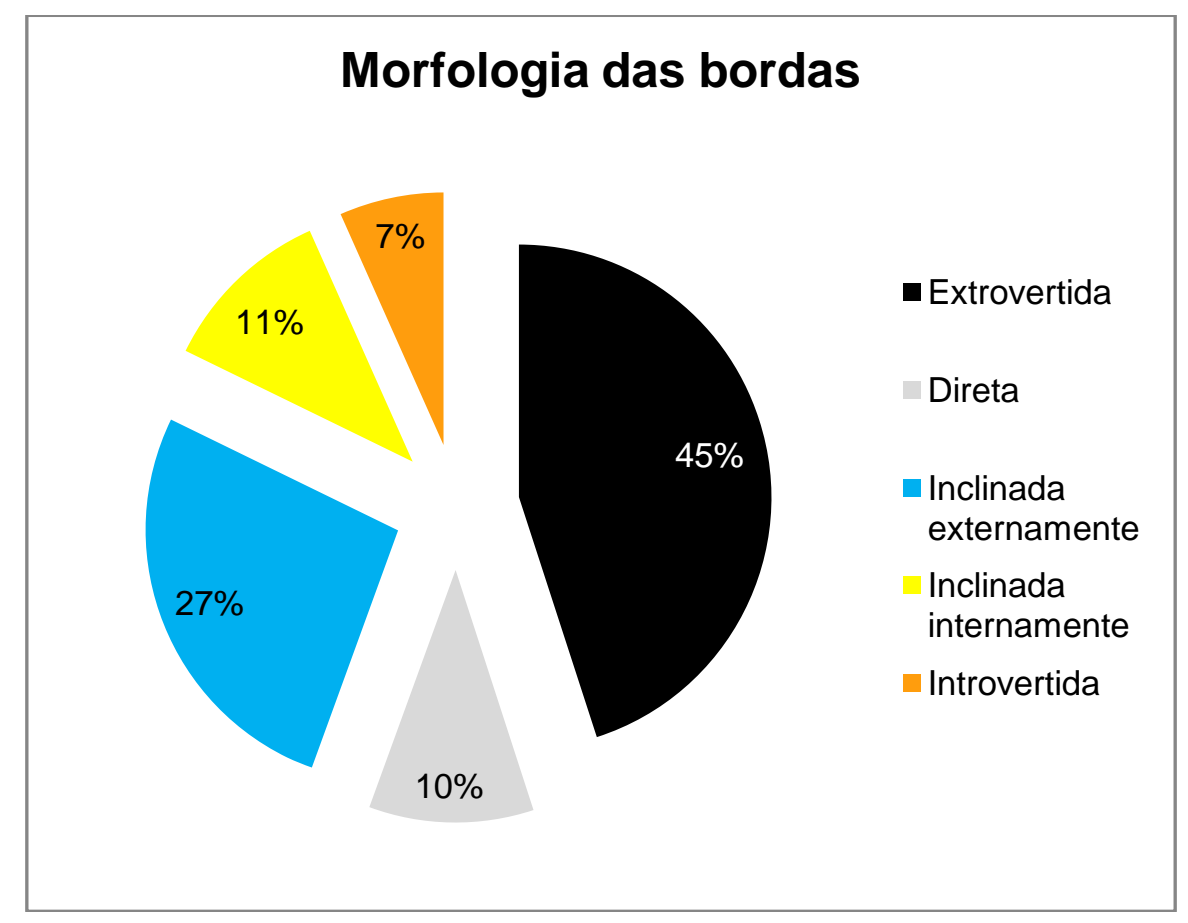

Gráfico 13: Quantidade de bordas por morfologia 
Quanto ao espessamento, o mais encontrado foi o normal, ou direto - quando a espessura entre o lábio e a quebra do fragmento são iguais - em $87,6 \%$ dos fragmentos. A ocorrência dos tipos expandida, dobrada e contraída foi raríssima, somando todos os casos $2,6 \%$ das bordas analisadas.

Já os reforços - divididos entre internos e externos - foram diagnosticados em $10,1 \%$ das bordas. Trata-se de aplicações feitas, com dito, tanto na parte interna quanto externa da porção superior (próximo ao lábio) dos potes, ocorrendo entre as bordas diretas, inclinadas externamente, em 3,3\% dos fragmentos; o tipo de reforço mais popular foi o externo, em bordas extrovertidas $(5,6 \%)$, tendo dois casos com diâmetro de boca estabelecido, entre $16-17 \mathrm{~cm}$. 
IMAGEM 38 e TIPOS DE BORDA 
39 DOS PERFIS DOS 


\subsubsection{Tipo de lábio}

Os lábios foram identificados como arredondado, plano, apontado e biselado. $O$ Primeiro tipo foi o dominante $(83,5 \%)$, enquanto os demais representaram 16,5\%.(Gráfico 14)

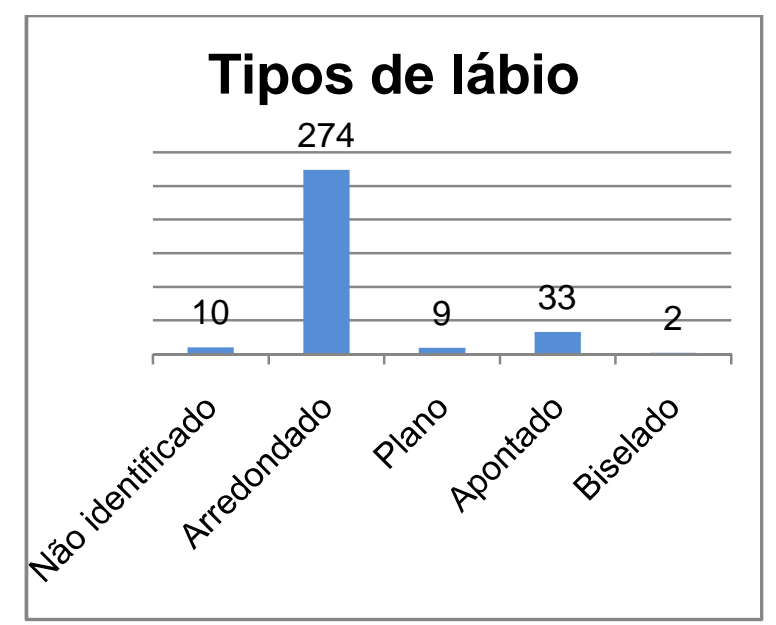

Gráfico 14: Freqüência dos tipos de lábio identificados.

Ao relacionar a distribuição dos tipos de lábio com a morfologia das bordas percebemos que nas de morfologia extrovertida são encontrados todos os tipos de lábio classificados no sítio, apesar do plano quase não ocorre entre as bordas extrovertidas. Nas introvertidas não temos a presença do tipo biselado, nem do apontado.(Gráfico 15).

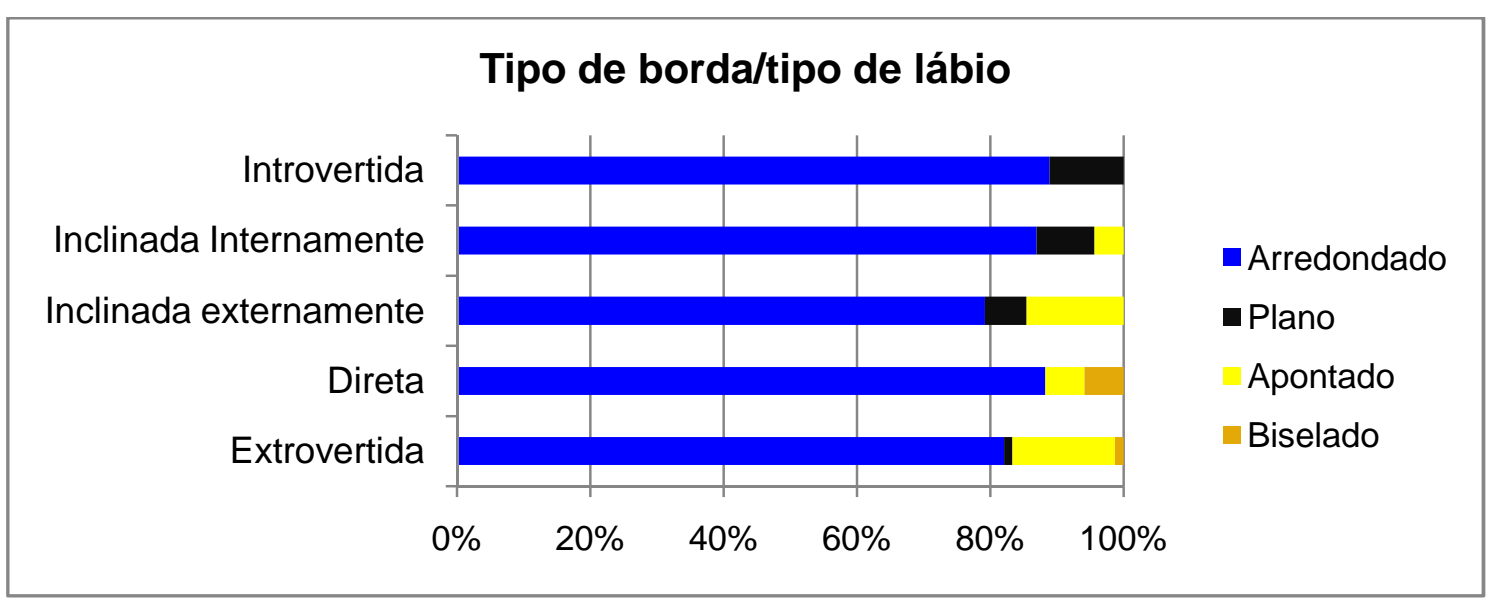

Gráfico 15: relação morfologia da borda/tipo de lábio 


\subsubsection{DIÂMETRO DA BOCA}

Em 18,75\% das bordas foi possível identificar o diâmetro da boca, que variou entre 6 e $48 \mathrm{~cm}$. Valores entre 14 e $24 \mathrm{~cm}$ foram predominantes; (Gráfico 20).

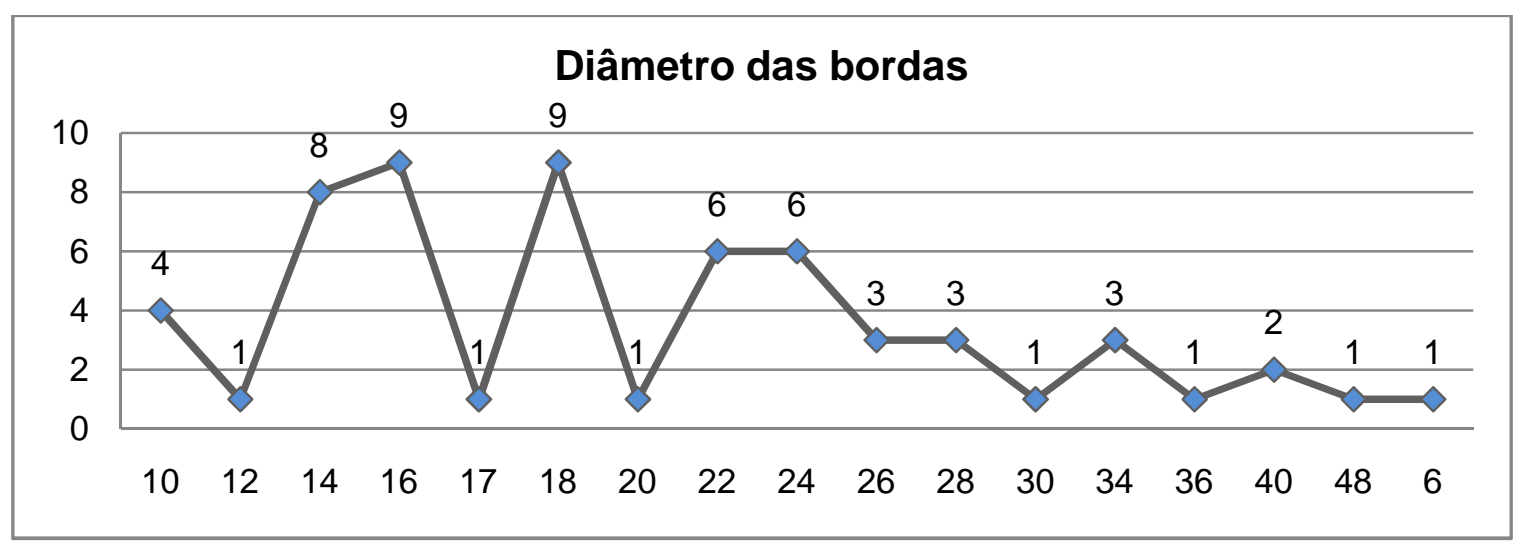

Gráfico 16: Diâmetro das bordas

A distribuição dos tipos de morfologia da borda entre os diâmetros de boca apontados evidencia que as bordas extrovertidas, maioria na coleção, ocorrem em praticamente todos os diâmetros, em proporção semelhante, desde $10 \mathrm{~cm}$, até $48 \mathrm{~cm}$, com os diâmetros de $16 \mathrm{~cm}(20 \%)$ e $24 \mathrm{~cm}(14 \%)$ como medidas mais populares. As bordas diretas, inclinadas externamente e internemente, são encontradas entre 6 e $26 \mathrm{~cm}$, em $64,3 \%$ dos fragmentos entre $14-18 \mathrm{~cm}$. As introvertidas, minoria na coleção, ocorrem entre os menores diâmetros, entre $10-14 \mathrm{~cm}(40 \%), 22 \mathrm{~cm}(40 \%)$ e $28 \mathrm{~cm}(20 \%)$.

Percebemos que os tipos de bordas mais abertos, de diretas ${ }^{30} \mathrm{a}$ inclinadas externamente $^{31}$, e principalmente extrovertidas ${ }^{32}$, dominam a coleção, representado $77,77 \%$ da amostra de bordas.

\subsubsection{Morfologia das Bases}

Foram raríssimas as bases recuperadas durante as escavações. A triagem resultou somente em oito fragmentos, que quanto a morfologia, foram identificadas como planas. Em dois casos foi possível identificar a técnica de

\footnotetext{
$30 \quad 10,75 \%$

$3126,66 \%$

$3240,35 \%$
} 
acordelamento na manufatura mesmo desde a base. Nos demais fragmentos não foram identificados sua técnica de manufatura.

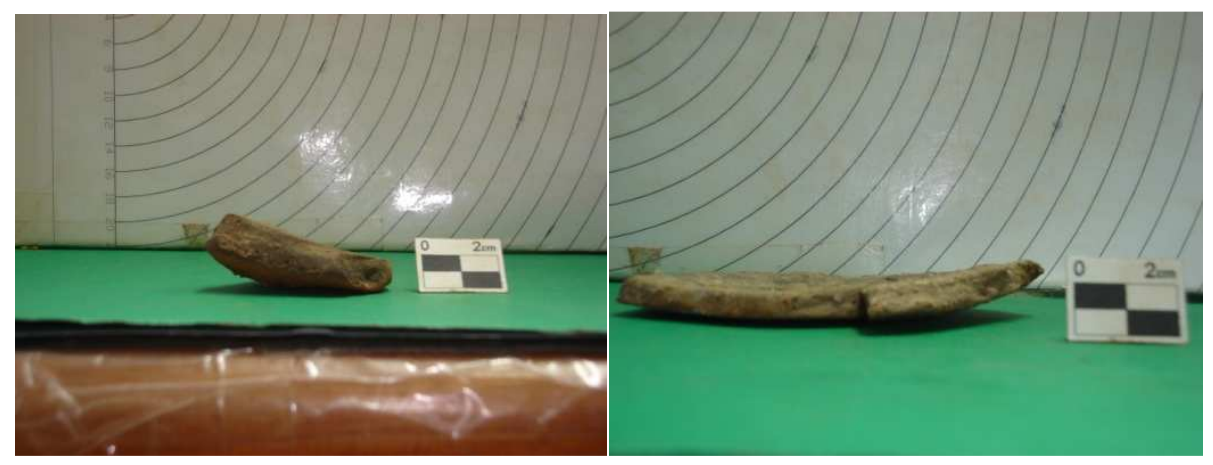

Imagem 40 : bases planas identificadas

\subsubsection{Decorações Plásticas}

Fragmentos com decoração plástica representaram 3,3\% dos casos analisados, sendo classificados em seis tipos: corrugado, corrugado-ungulado, roletado, inciso, inciso fino, e entalhado e digitado.

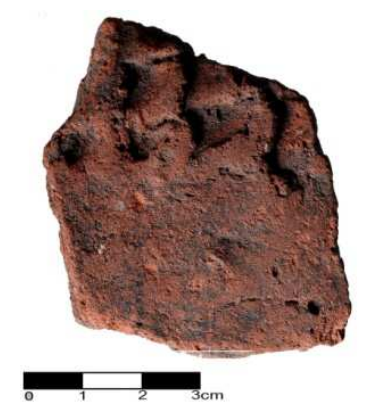

Imagem 41: fragmento entalhado

A decoração plástica mais freqüente foi o corrugado (36,7\%), seguido do roletado e inciso, que ocorrem na mesma proporção $(23,3 \%)$. Segue com 0 ungulado, presente em $11,2 \%$; os casos de menor ocorrência são os tipos inciso fino e corrugado ungulado $(3,9 \%)$ e, entalhado e digitado, com 1,9\%.(Gráfico 17) 


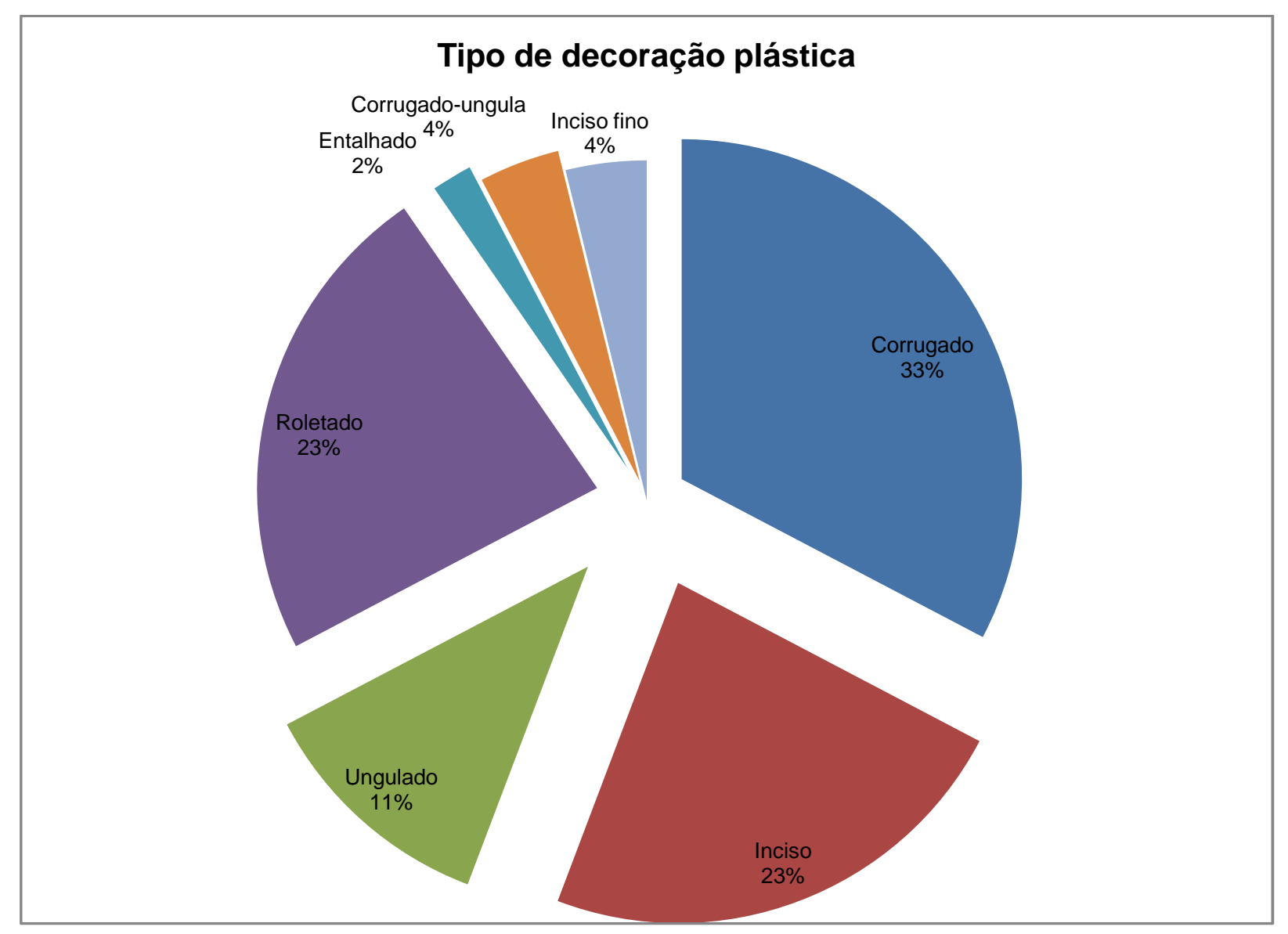

Gráfico 17 : Tipos de decoração plástica

As decorações plásticas, como no caso do tipo corrugado, foram encontradas em sua maioria em fragmentos classificados como bordas e partes do pote relacionadas ao ombro. A presença do tipo apenas nestes locais, segue uma delimitação semelhante a decoração pintada, que tem como delimitadora da decoração, normalmente, o maior ponto de inflexão no pote. Dentro do tipo corrugado, note-se uma variação interna de tipos, conforme a imagem 41 : 

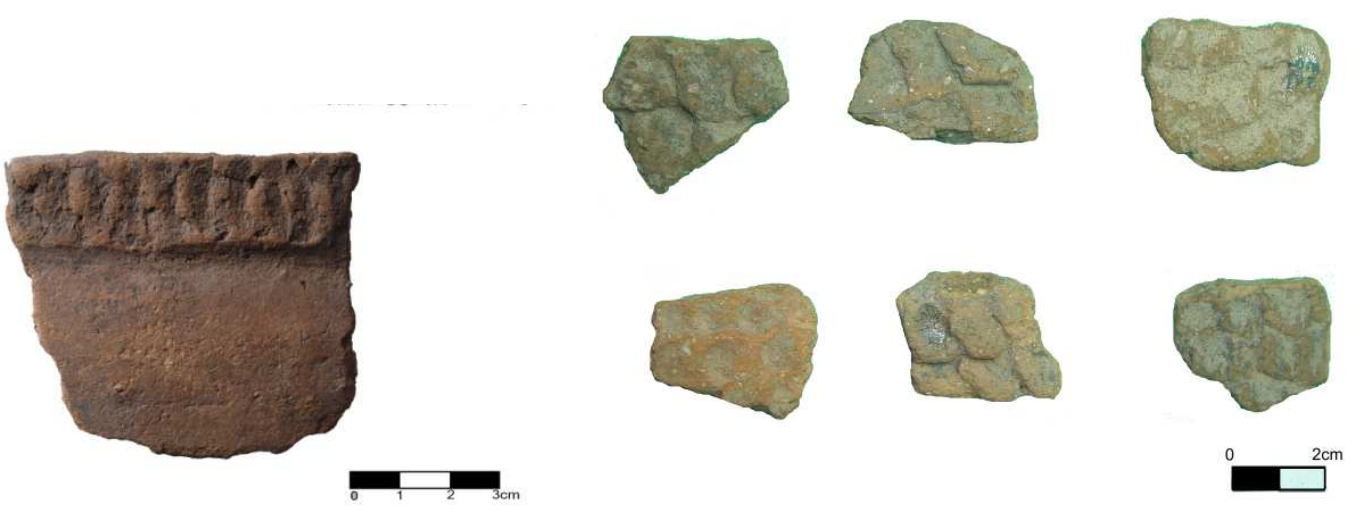

Imagem 42: fragmentos corrugados. A esquerda En-, acima,da esquerda da pra direita, En-, abaixo, En-.

Outro caso semelhante foi o modo como o roletado foi utilizado, que ocorre também somente até o maior ponto de inflexão dos potes. Um traço interessante diagnosticado associado a esta técnica é a ocorrência de uma espécie de falha, rompendo os roletes verticalmente, ocupando superfície considerável, conforme abaixo na imagem 42 :

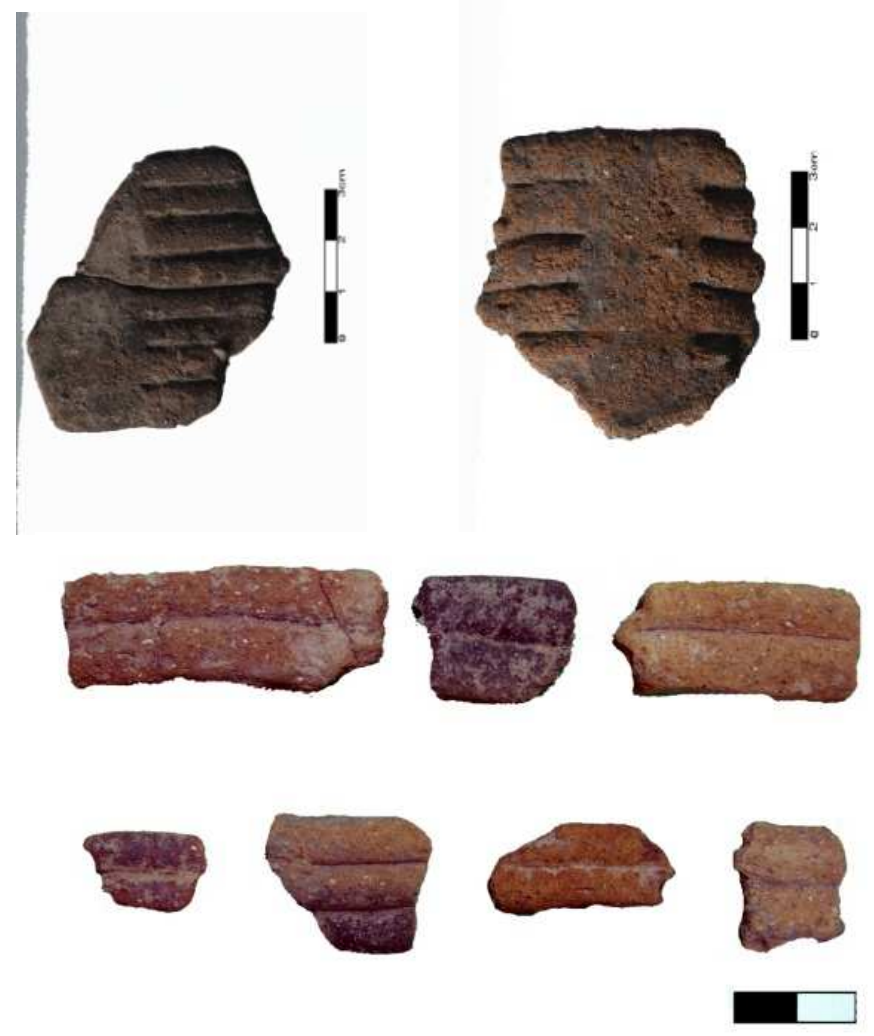

Imagem 43: acima, dois fragmentos com a falha citada, e abaixo, fragmentos roletados sem a anomalia. 
Em 25\% dos tipos de roletado ocorre esta marca, que, até o momento, é entendida como decorrência da erosão de determinada espécie de aplique na borda, por exemplo. A ocorrência de apliques no sítio foi praticamente nula, salvo um fragmento, de proporção muito reduzida, não correspondendo a falha diagnosticada nas bordas.

As incisões encontradas foram divididas dada a espessura nos tipos inciso e Inciso fino (Imagem 44). A ocorrência destas incisões estão localizadas na maioria dos casos junto as bordas(75,4\%). Assim como o tipo ungulado, é recorrente no sítio encontrar estas decorações junto a bordas de vasilhas abertas, com reforço no lábio. A reunião destes atributos estabelece um tipo que é evidenciado em $18,75 \%$ dos fragmentos decorados analisados, e $40,9 \%$ das bordas com decoração.
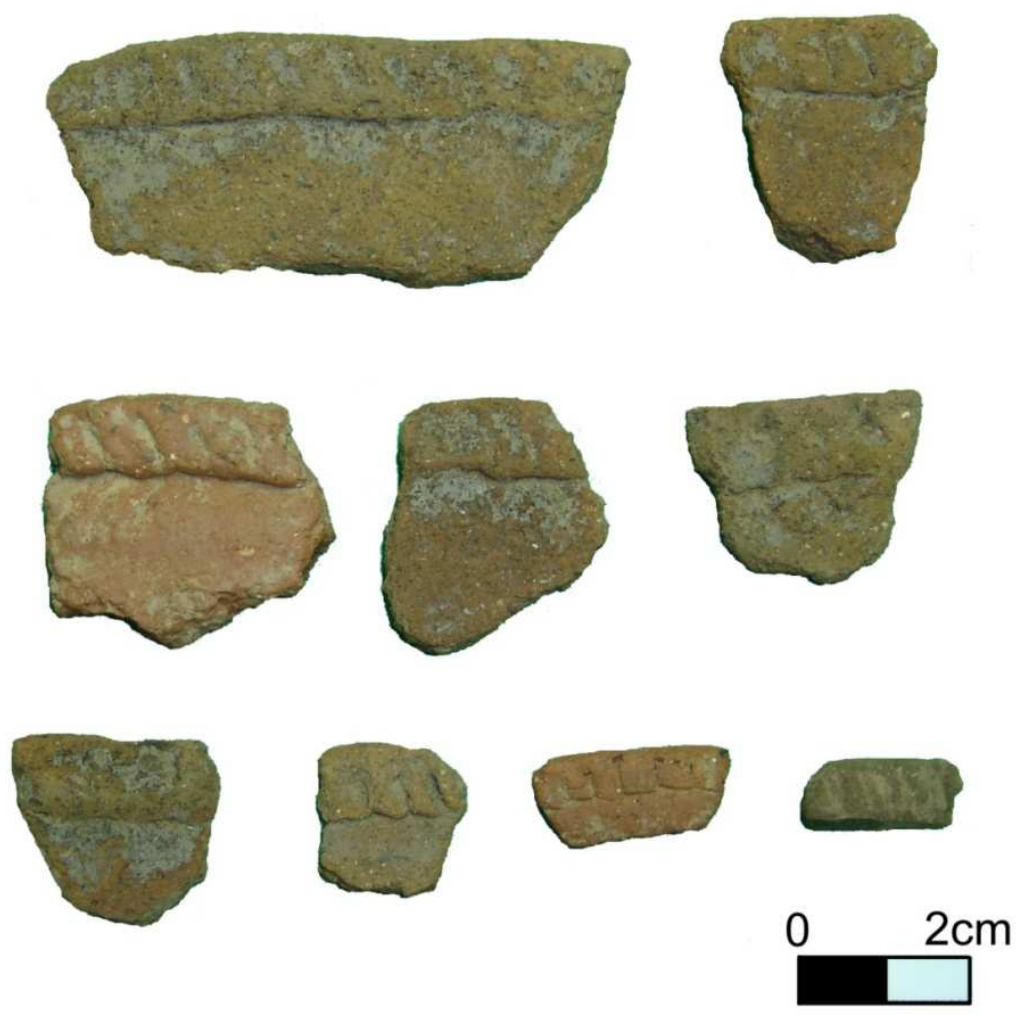

Imagem 44: incisos em bordas reforçadas. 


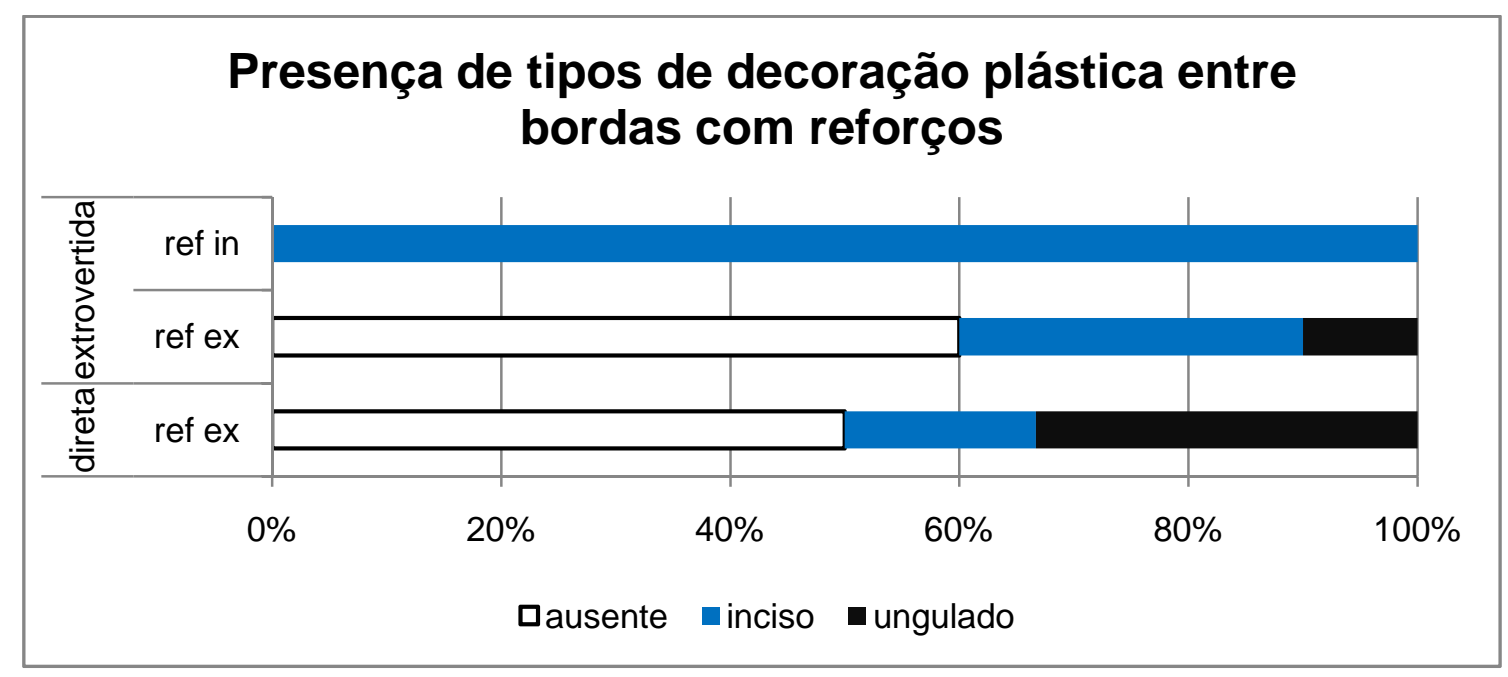

Gráfico 18: presença de decoração entre bordas reforçadas. (Ref in: reforçada internamente, e Ref ex: reforçada externamente).
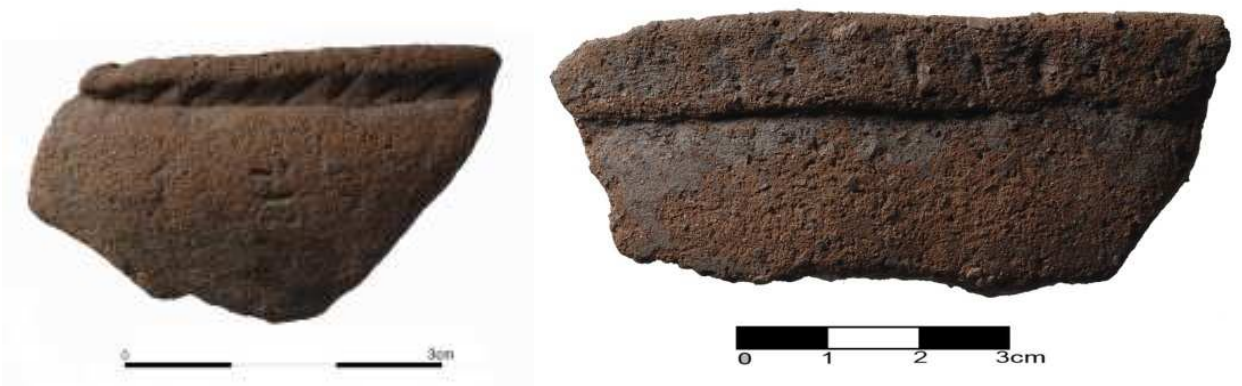

Imagem 45: a esquerda Inciso fino, e a direita inciso.

O ungulado ocorre de duas maneiras, isolado, em fragmentos de bordas e paredes, e associado ao corrugado, encontrado somente em paredes. (Imagem 45 e 46$)$. 

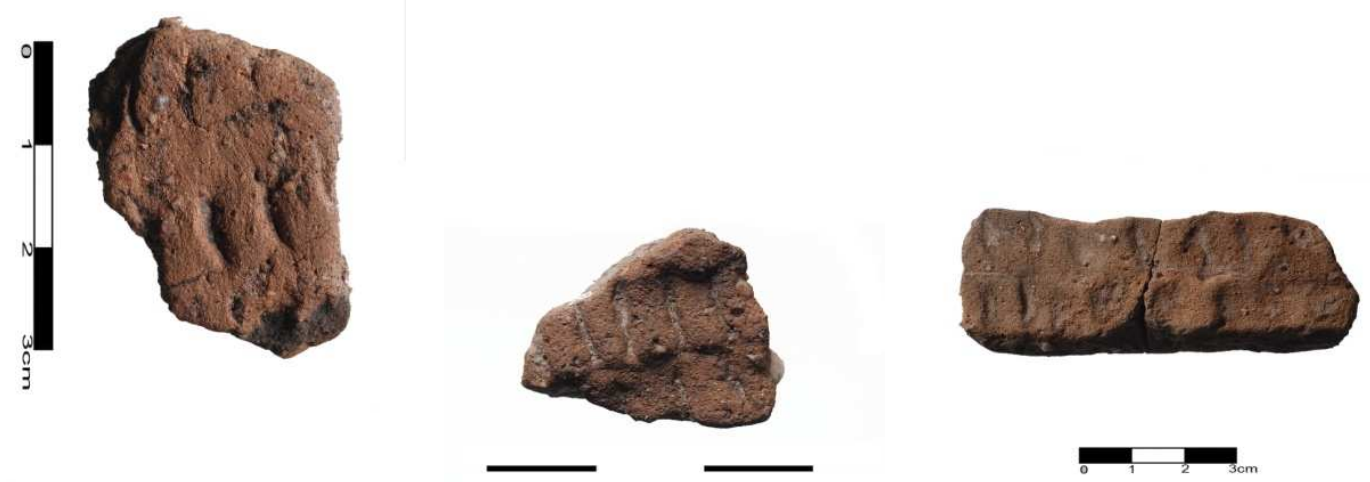

Imagem 46: a esquerda representante do tipo ungulado e no centro e direita corrugado-ungulado.

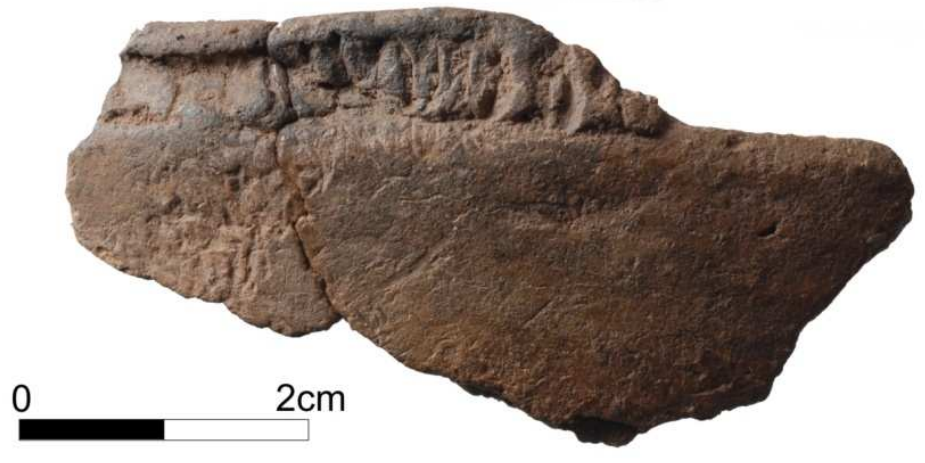

Imagem 47: borda com reforço ungulada, En-676-679.

\subsubsection{Decorações Pintadas}

A análise da decoração pintada foi realizada a partir da observação de vestígios - no caso do sítio, em fase avançada de erosão - de camadas de pigmentos na superfície da cerâmica.

A decoração pintada evidenciada foi aplicada diretamente sobre a superfície cerâmica, ou sob engobo vermelho, ocorrendo em ambas as faces do fragmento. Apesar de restritos, apenas $0,62 \%$ da coleção, a classificação dos tipos resultou seis combinações entre o uso de superfície alisada/engobo vermelho, pintura branca/vermelha/preta. (Gráfico 19). 


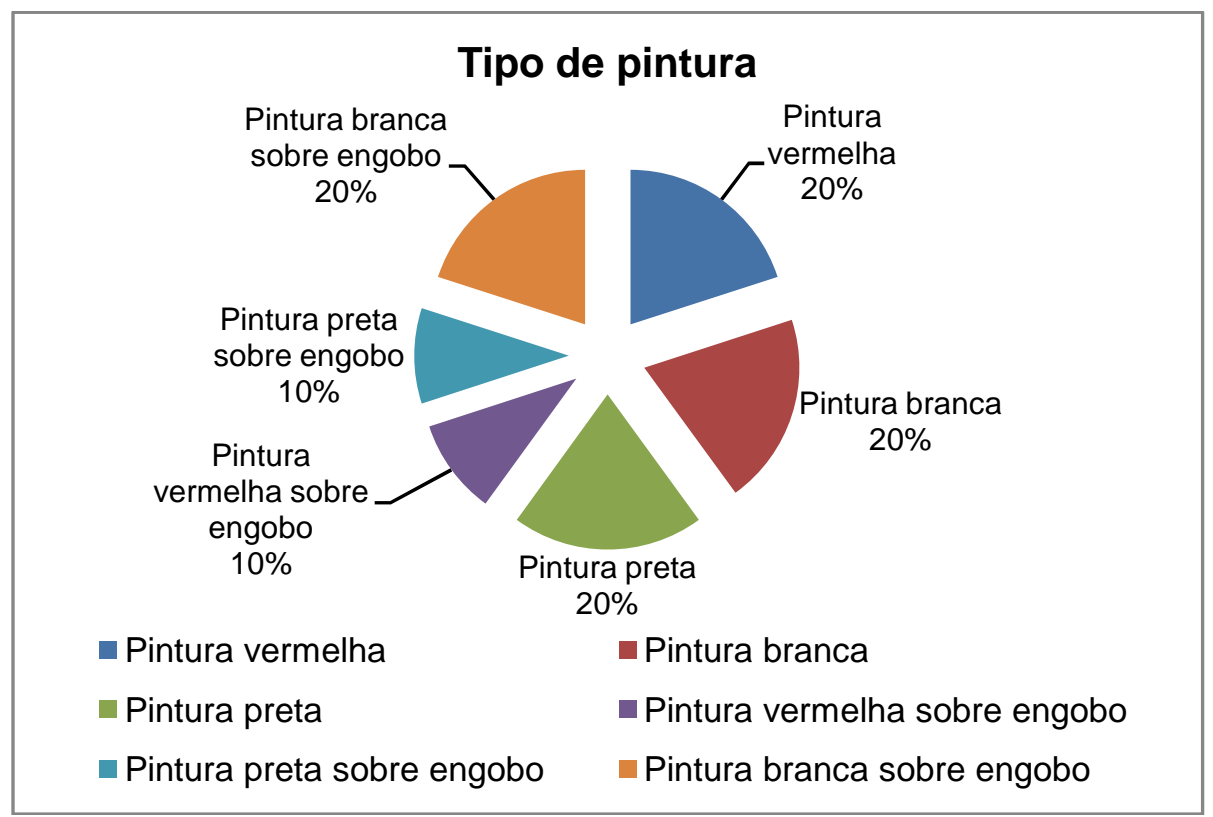

Gráfico 19 : Tipos de decoração pintada, como mencionado, o engobo vermelho foi o único identificado.
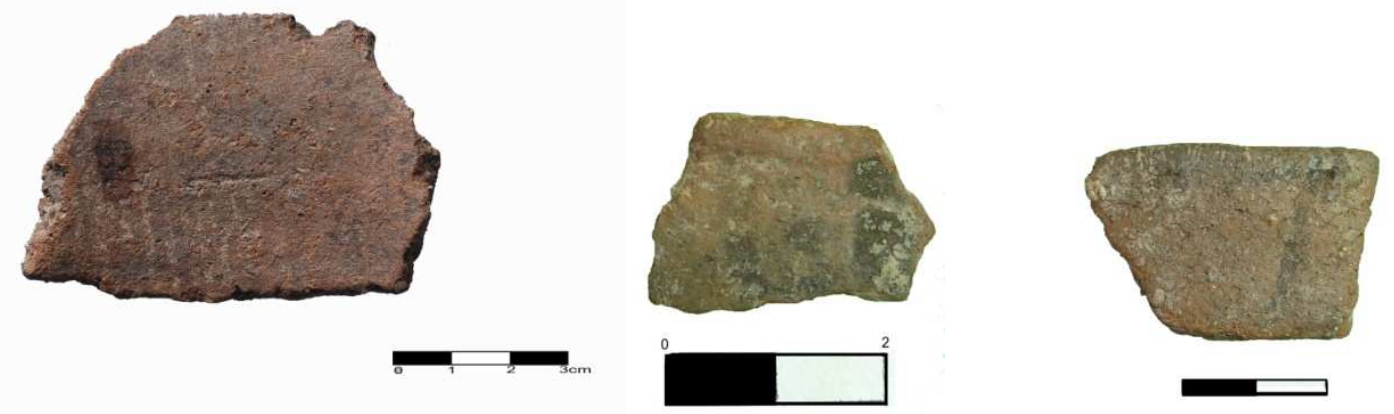

Imagem 48: a esquerda, pintura branca, centro e direita, pintura preta.

Com exceção de um caso, de pintura branca na face interna, nos demais, o estado erosivo da pintura inviabilizou a identificação dos motivos. O motivo identificado se trata de linhas finas ( 1 a $2 \mathrm{~mm}$ ) paralelas, conforme a imagem 50 , na página a seguir.

O engobo vermelho, único tipo de engobo identificado, ocorreu também sem associação à pintura em 1,92\% dos casos. Segundo autores (Rice 1987, Rye, 1987 entre outros), o engobo vermelho normalmente consiste na aplicação de uma suspensão, feita a partir da argila e óxido de ferro (que pode estar presente na argila) na superfície da cerâmica antes da queima. 

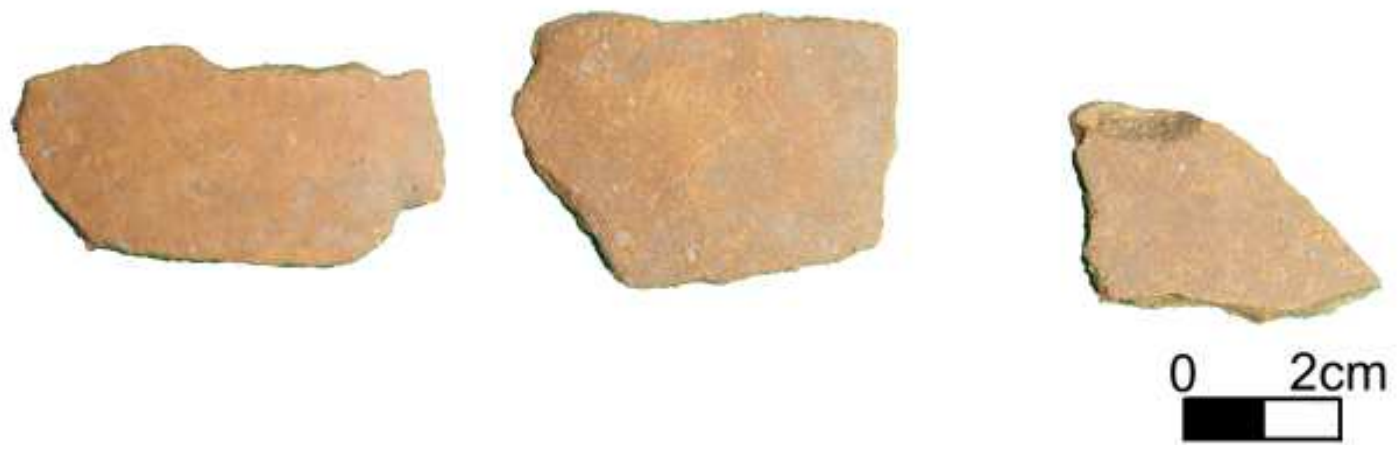

Imagem 49: fragmentos com engobo vermelho 
IMAGEM 50 motivos de pintura identificados. 


\subsection{QUALIFICAÇÃO dOS ATRIBUTOS - CARACTERIZANDO A INDÚSTRIA CERÂMICA DO SÍTIO ENCONTRO}

A partir dos dados expostos anteriormente já podemos ter as primeiras impressões das características da indústria cerâmica do sítio Encontro. Os utensílios, com antiplástico mineral(areia), variando em $20 \%$ a $30 \%$ de presença na pasta, eram construídos a partir da técnica do acordelamento, tendo espessura predominante entre 0,7 e $0,9 \mathrm{~cm}$. O alisamento, tipo de tratamento de superfície predominante (mais de 94\%), foi diagnosticado na metade dos casos junto à presença da barbotina. Apesar de pouco freqüente, 0 polimento esteve presente, com uma tendência a ser executado na face interna em potes com espessura mais finas que $0,8 \mathrm{~cm}$.

\section{A variabilidade da Cor da pasta}

Ao avaliarmos a variabilidade dos tratamentos de superfície a partir da presença/ausência de decoração, por exemplo, constatamos que aparentemente a variabilidade dos tipos de tratamento de superfície é restrita, sendo o alisamento o tipo mais popular, com 94,5\%. A grande presença de indivíduos alisados nos levou a procurar elencar tipos na análise que pudessem entender se houveram, ou não, variações, mesmo que discretas, entre a grande população de indivíduos alisados presentes no sítio.

A primeira impressão, o primeiro que diferencia esta população de indivíduos alisados, é a cor da pasta. Esta é uma variável que já vem sendo utilizada de forma bem sucedida, como no caso de Machado (2006), que identifica escolhas de determinadas cores de argila, com a utilização de determinado antiplásticos, em cerâmicas da Amazônia central.

Tomamos os tipos de cor da pasta como categoria básica na comparação entre os tipos identificados como alisados, buscando identificar dados que possam caracterizar o uso da argila na elaboração dos utensílios cerâmicos. A partir desta, comparamos atributos relacionados a tecnologia e morfologia, além de cruzar os dados com os tipos de decoração. 
No caso do sítio, conforme indicamos, temos quatro tipos estabelecidos: laranja, marrom, vermelho e amarelo. $O$ valor relativo às cores laranja e marrom somados tem representatividade de $89,2 \%$, e são neles que encontramos grande parte da variabilidade ${ }^{33}$ diagnosticada no sítio. Os tipos vermelho e amarelo, possuem especificidades, estas, ligadas mais a atributos tecnológicos (variação de antiplástico), e morfológicos (tipos de borda, espessura do fragmento)

Nas quatro diferentes tonalidades de cor não houveram grandes diferenças entre o tipo de antiplástico identificados. Em todos o componente não plástico da argila era o mineral. Ocorreu, como abaixo indicado (Gráfico 20), uma diferença entre a dimensão do maior antiplástico identificado na quebra.
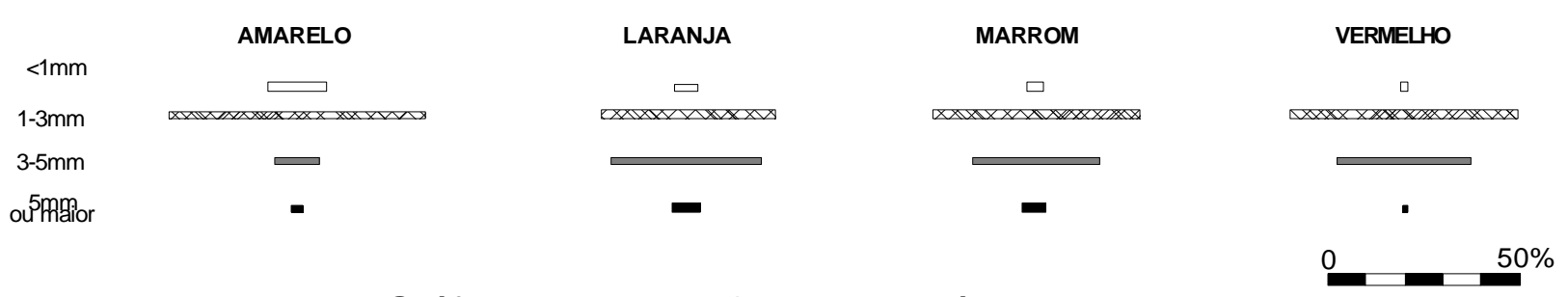

Gráfico 20: dimensões do antiplástico

Em todas as cores existe o predomínio das dimensões entre 1-3mm. Contudo, na pasta amarela encontramos mais indivíduos nesta medida (71,3\%), além de uma proporção maior de fragmentos com antiplástico de até $1 \mathrm{~mm}(18,2 \%)$, e raros com mais de $5 \mathrm{~mm}(4,4 \%)$, tendência antagônica as cores laranja e marrom.

Logo, se na pasta amarela os indivíduos tendem a ter um antiplástico menor, a sua ordenação também tende a ser diferenciada das outras cores. As cores vermelho, marrom e laranja possuem semelhança na proporção dos tipos de

\footnotetext{
${ }^{33}$ Nestas cores encontramos todas variáveis de itens como: categoria, tipo de antiplástico, espessura de antiplástico, tratamento de superfície, barbotina, decoração plástica, diferentes tipos de borda.
} 
ordenação, com o tipo de ordenação predominante o muito pobre ${ }^{34}$, seguindo do pobre ${ }^{35}$, diferentemente da pasta amarela, que novamente demonstra variação, atestando uma proporção maior de fragmentos equilibrados e bem ordenados $^{36}$. (Gráfico 21$)$

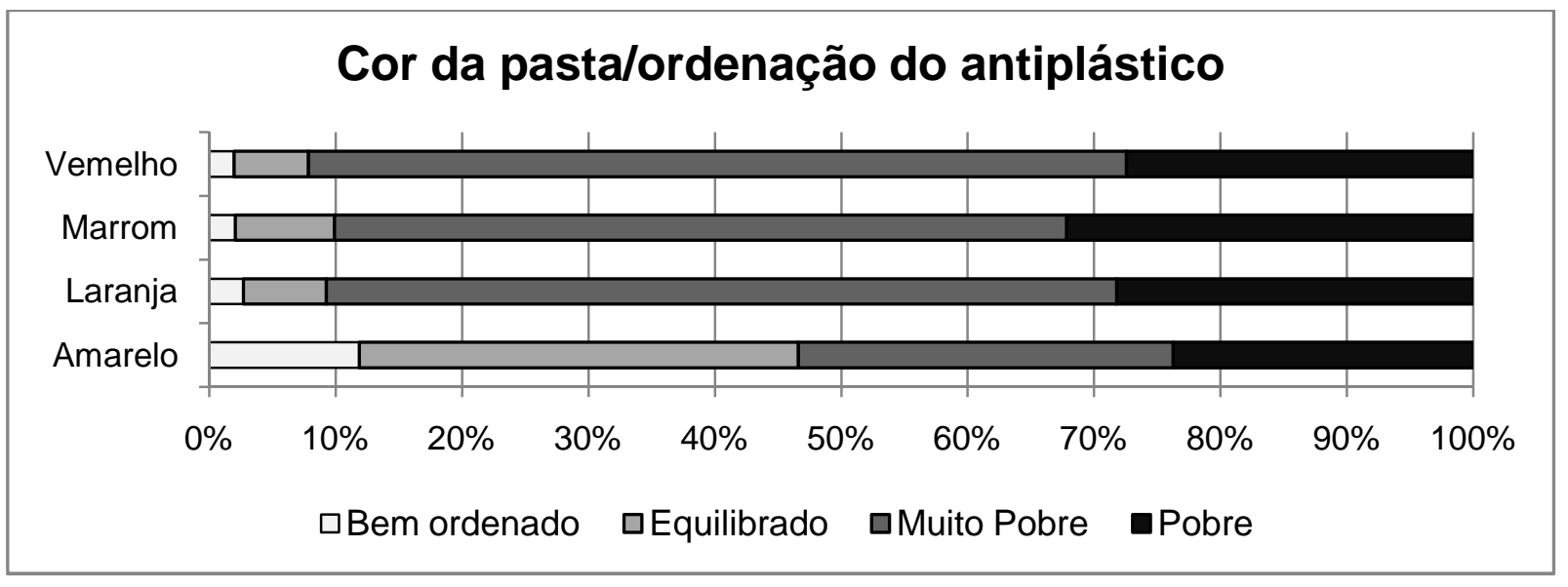

Gráfico 21: proporção dos tipos de ordenação do antiplástico nas diferentes cores identificadas.

$\mathrm{Na}$ comparação da freqüência do antiplástico percebemos que as pastas amarela e vermelha possuem características semelhantes, assim como as pastas laranja e marrom. Proporcionalmente o tipo amarelo possui menos antiplástico que as outras cores, sendo os tipos mais populares nesta tonalidade, aqueles relacionados a pouca freqüência do antiplástico. Enquanto que nas cores laranja e marrom, os tipos mais populares estão entre A2 e C3(97,3\%), no amarelo estão mais freqüentes A1 e A3 (71,2\%). Na cor vermelha ocorre uma tendência semelhante a com a pasta amarela, os tipos A1, A2, A3, representam 47,2\%. (Gráfico 22)

\footnotetext{
${ }^{34}$ laranja $62,52 \%$, marrom $57,92 \%$, vermelho $64,72 \%$.

${ }^{35}$ Iaranja $28,21 \%$, marrom $32,16 \%$, vermelho $27,45 \%$.

${ }^{36} \mathrm{Na}$ pasta amarela a soma de bem ordenado mais equilibrado é $46,6 \%$, enquanto que na cor laranja é: 9,25\%; marrom 9,9\%; vermelho 7,85\%.
} 


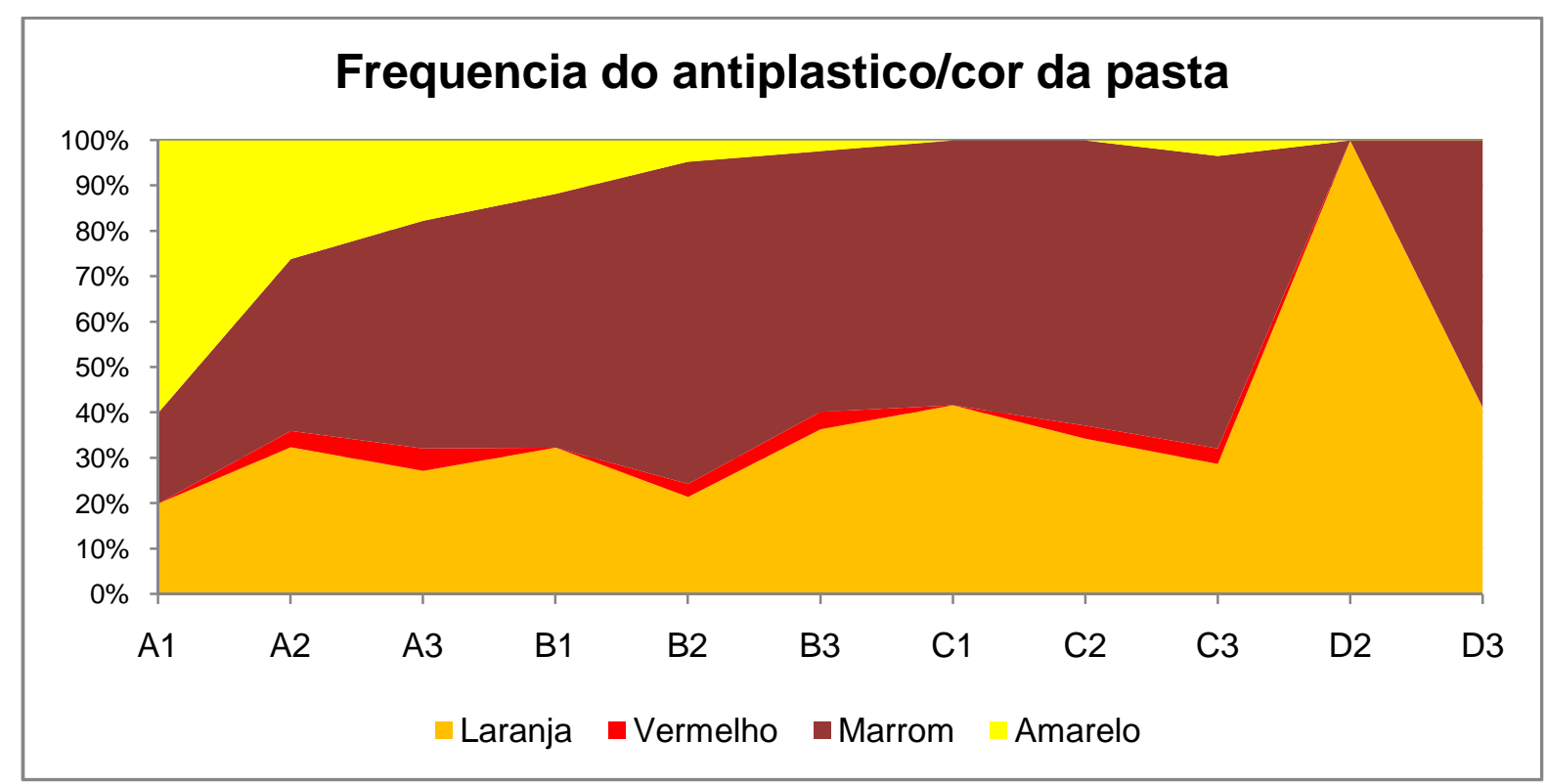

Gráfico 22: proporção da freqüência do antiplástico entre as diferentes cores.

Ao relacionarmos as dimensões, ordenação e freqüência do antiplástico, percebemos que as diferenças ocorrem de maneira significativa entre a pasta amarela e as demais cores, mais semelhantes. Esta pasta amarela pode ter sido trabalhada de modo diferente, ou ser proveniente de um local de coleta de matéria-prima distinto da pasta laranja, marrom e vermelha. É interessante também observar que, se relacionarmos a freqüência e a ordenação, alguns tipos se destacam em determinadas cores, como é o caso do B2 e B3 muito pobre e pobre, no laranja, marrom e vermelho. Já no amarelo ocorrem mais tipos finos como A1 A2 A3 mais ordenados. (gráfico 23) 
Seriação gráfico 23 


\section{Tratamento de superfície}

O tratamento de superfície mais popular, em todas as cores da pasta, foi o alisamento. Já decoração plástica ocorre em todas as tonalidades, e com exceção da pasta amarela, o polimento, o engobo vermelho e a decoração pintada estão sempre presentes. (Gráfico 24)

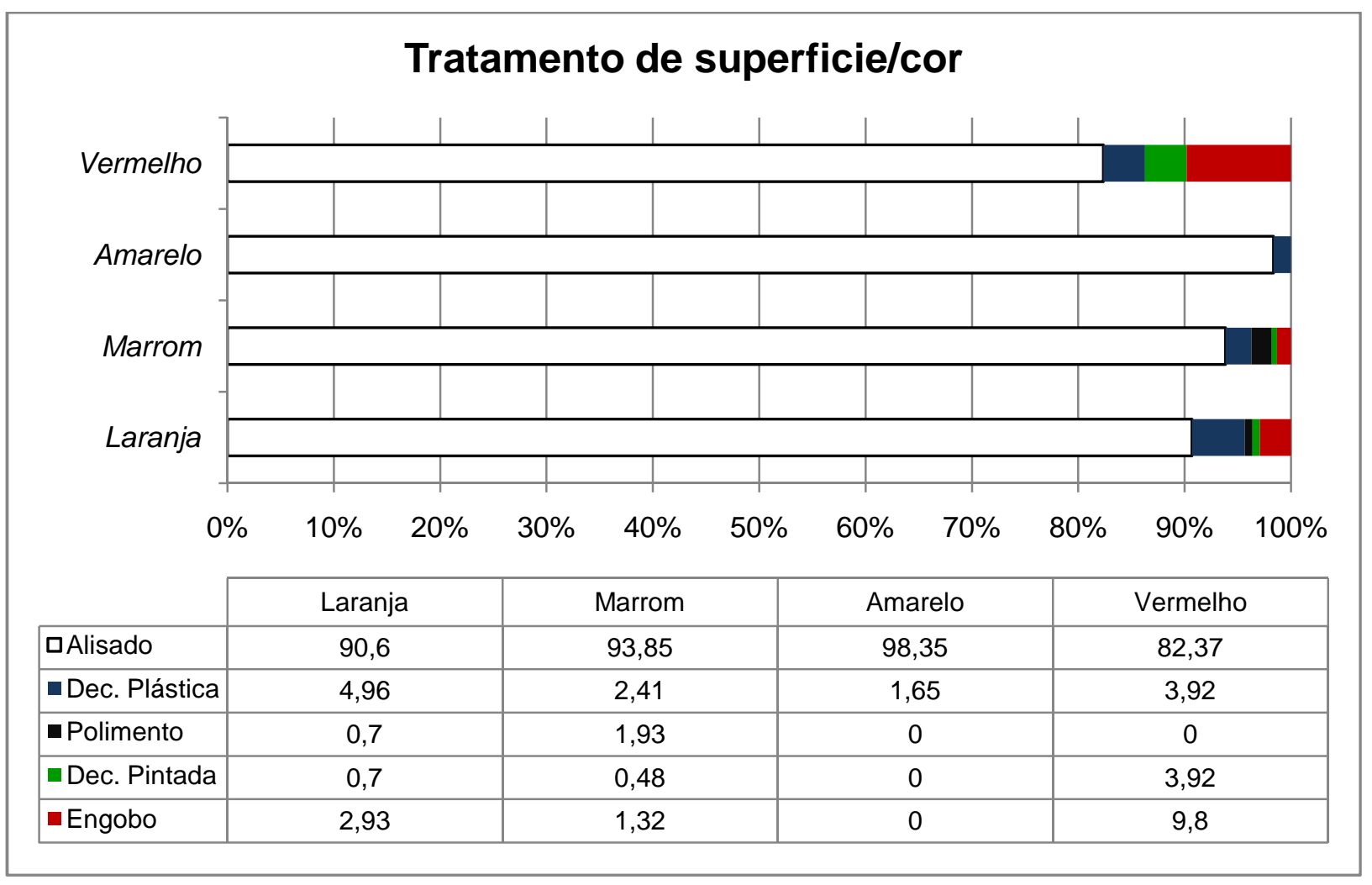

Gráfico 24: tipos de tratamento de superfície entre as diferentes cores. Os dados da tabela acima são porcentagens.

$\mathrm{Na}$ cor laranja predominam os tipos com decoração plástica, o dobro em relação a pasta marrom, e quase o triplo do amarelo. Na pasta marrom encontramos o maior índice de fragmentos polidos. Estas superfícies polidas foram diagnosticadas somente entre as pastas de cor laranja $(18,2 \%)$ e predominantemente na marrom, em $81,8 \%$ das ocorrências.

A pasta amarela é a que possui maior indicador de tipos alisados e, além disso, não ocorre o polimento, engobo ou pintura, caracterizando-se como o tipo de tratamento de superfície mais homogêneo entre as cores. 
Entre os indivíduos alisados, em muitos, esta associada a barbotina, principalmente entre a pasta a vermelha $(61,6 \%)$. Nesta e nas pastas marrom $(50,9 \%)$ e laranja $(44,9 \%)$ a proporção da presença da barbotina fica semelhante a encontrada considerando todas as cores $(48,9 \%)$. A pasta amarela é que apresenta menos fragmentos com este tratamento de superfície, em $34,5 \%$ dos casos. (Grafico 25 ).

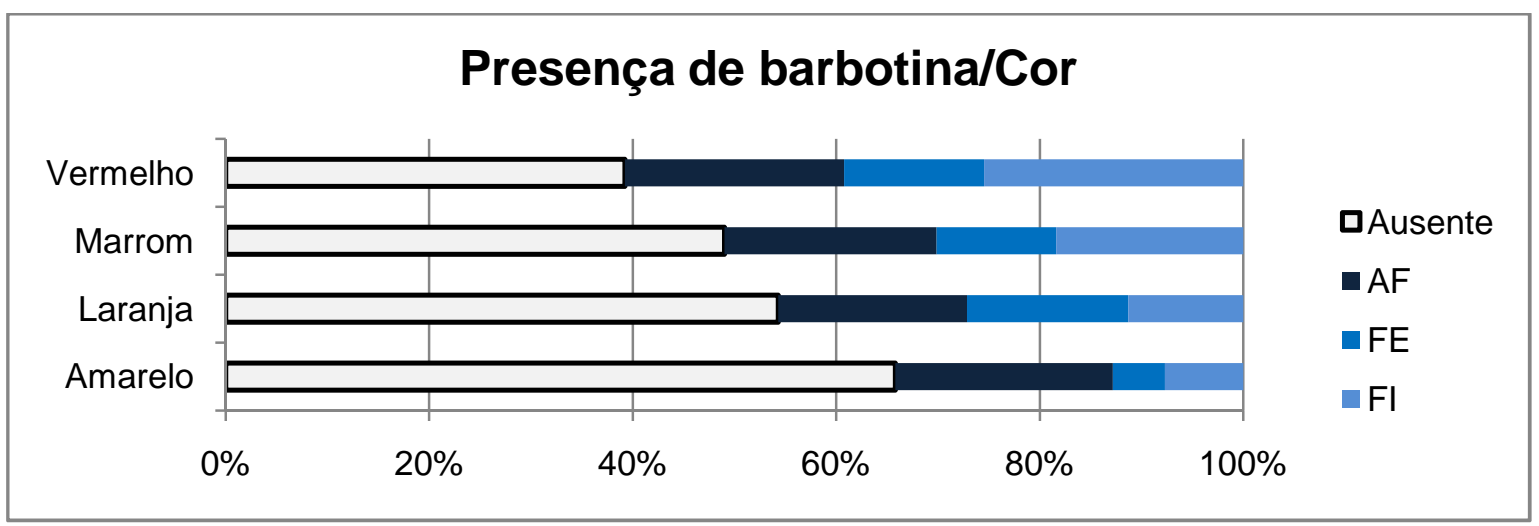

Gráfico 25: proporção de fragmentos com barbotina entre as cores. Na legenda siginificam: $A F-$ Ambas as faces; FE - Face externa; FI- Face interna.

\section{Morfologia}

As comparações entre os dados referentes à morfologia dos fragmentos também apresentam variações, que como no caso dos indicativos tecnológicos apontados acima, tendem a ter a pasta amarela como indivíduo estranho entre as demais cores.

Iniciando com a espessura dos fragmentos é possível afirmar que os indivíduos laranja possuem uma tendência a serem mais espessos em relação aos outros, e principalmente aos amarelos. Este fato é observado no gráfico $X X$, e salientase que é notável que na pasta amarela, e principalmente na vermelha, encontramos mais indivíduos entre os tamanhos médios a fino $(0,3-0,6 \mathrm{~cm})$. 


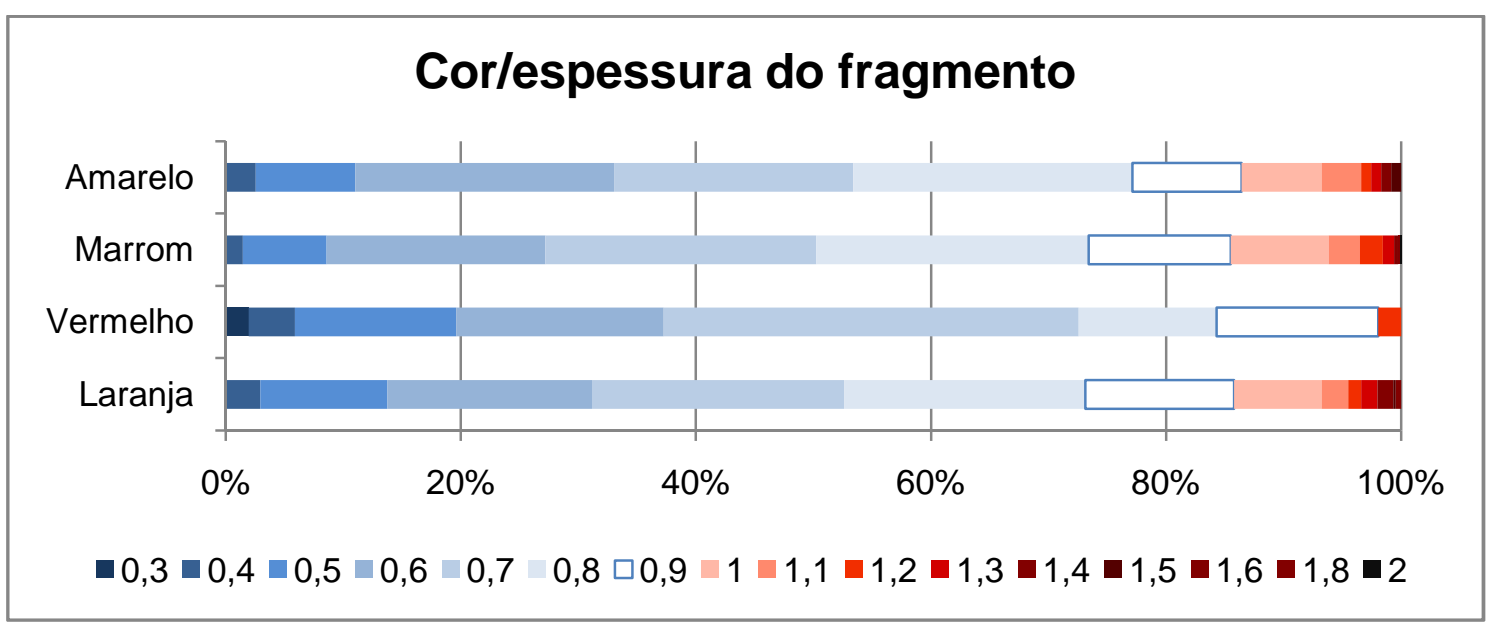

Gráfico 26 : Distribuição dos tipo de cor de pasta entre as medidas de espessura $(\mathrm{em} \mathrm{cm})$ dos fragmentos identificados.

Em relação a morfologia das bordas é importante perceber que no caso da pasta amarela, há uma maior disposição para bordas com morfologia extrovertida. A proporção deste tipo $(56,42 \%)$ nesta pasta é a mais representativa entre as cores ${ }^{37}$. As pastas marrom e laranja são semelhantes entre as bordas diretas, com $44,2 \%$ e $47,5 \%$ respectivamente, contudo a proporção entre extrovertidas e introvertidas é diferente, ou até antagônica, conforme podemos constatar no gráfico e tabela a seguir (Gráfico 27, tabela 8)

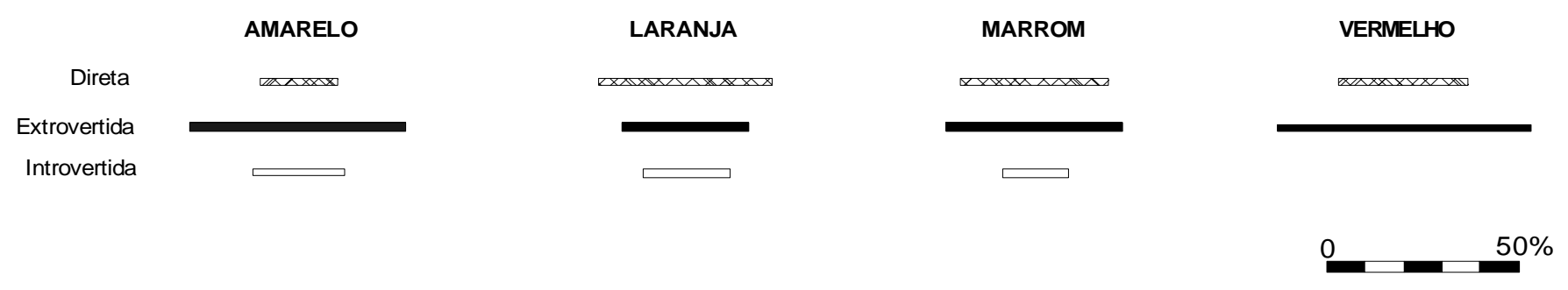

Gráfico 27 : distribuição dos tipos relacionados a morfologia da borda entre as diferentes cores de pasta.

\begin{tabular}{cccc} 
& Direta & Extrovertida & Introvertida \\
\hline Amarelo & $20,51 \%$ & $56,42 \%$ & $23,07 \%$ \\
Vermelho & $33,33 \%$ & $77,77 \%$ & - \\
Marrom & $47,5 \%$ & $45 \%$ & $7,5 \%$
\end{tabular}

\footnotetext{
${ }^{37}$ Apesar de que na pasta vermelha as bordas extrovertidas representam $77,7 \%$, considerouse a pasta amarela como mais significativa dado o tamanho da amostra analisada de indivíduos vermelho.
} 
Tabela 8: dados do gráfico 27 .

Um dos dados que chamam a atenção é que somente entre a pasta amarela que o tipo introvertida não é o menos representativo. Observamos que entre a cor as bordas tendem a ser extrovertidas, em sua maioria, ou introvertidas, restando poucos indivíduos correspondentes a morfologia direta, e sendo esta uma das principais diferenças das as cores.

\section{Decoração Plástica}

As pastas marrom e laranja apresentam maior variabilidade de tipos com decoração plástica, mas no entanto, é somente na marrom que encontramos todos os tipos. Ao mesmo tempo percebemos que o tipo corrugado, em mais da metade dos casos é laranja (56,8\%), enquanto que os tipos inciso, ungulado e roletado são em sua maioria marrom.

A partir da cor percebe-se uma tendência a utilização da pasta laranja, dado o alto índice de tipos com decoração plástica, o dobro em relação a marrom, e ainda mais nas outras cores, podendo este ser um indicativo entre a variação das cores e sua relação com a determinação do tipo de decoração plástica. 0 que mais chama a atenção é o grande numero de corrugados encontrados entre a cor laranja. (Gráfico 33)

Somente Marrom e laranja comportam grande variabilidade, e isto poderia ser considerado, já que na pasta amarela, por exemplo, ocorrem raros tipos decorados $(1,65 \%)$ e na vermelha são raros os cacos com decoração. 


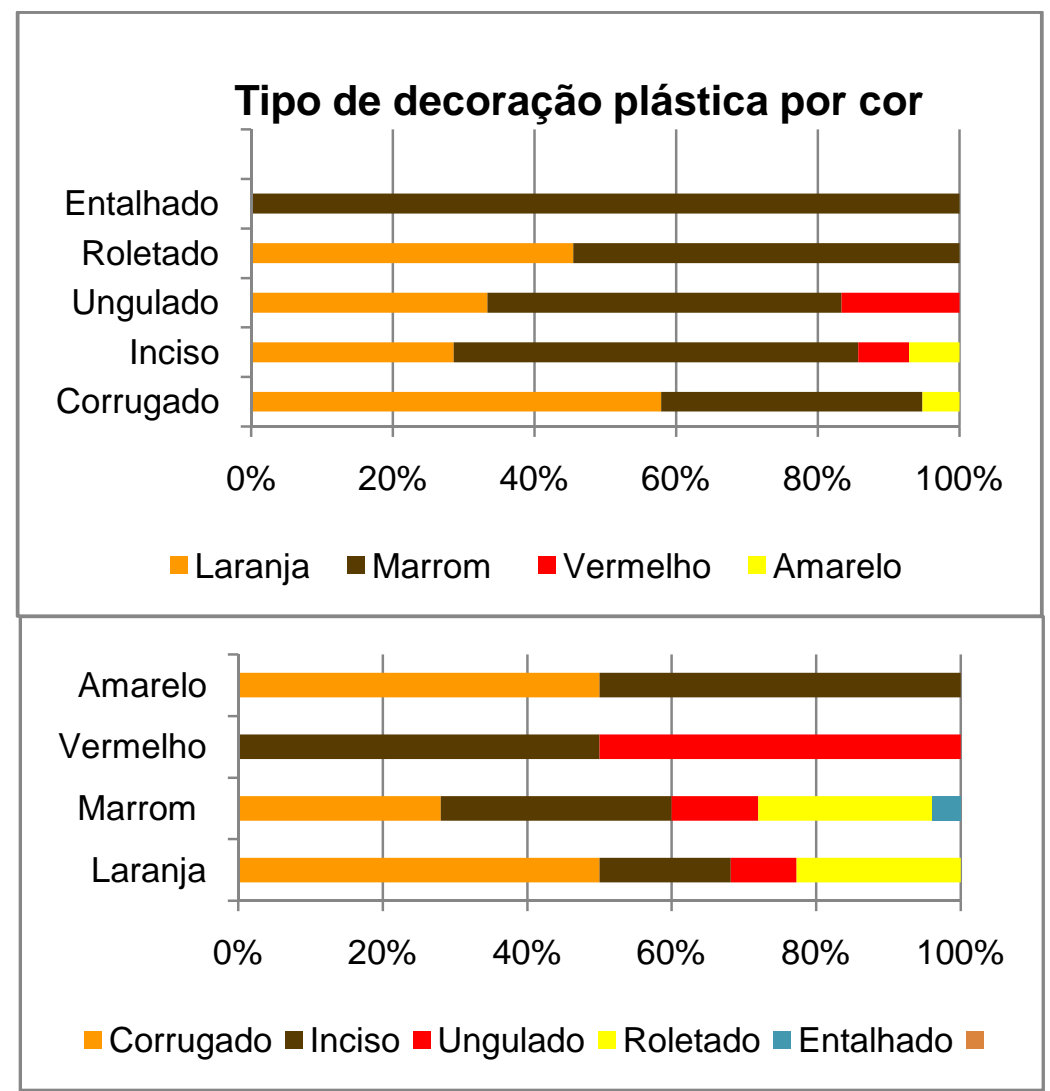

Gráfico 28: tipo de decoração plástica relacionados a cor dos fragmentos.

Na decoração pintada parecesse ter havido também uma tendência entre os tipos de pintura e a cor da pasta. Este comportamento começa a ser diagnosticado a partir da ausência de tipos pintados entre a pasta amarela. Não é surpresa, que na cor marrom, já em muitos aspectos levantados antagônica a amarela, encontramos todos os tipos de pintura. Mas o mais curioso é a distribuição dos tipos entre as pastas laranja e vermelha. Enquanto que na laranja ocorrem somente pinturas aplicadas sobre engobo vermelho, na pasta vermelha a pintura é exclusivamente aplicada a superfície. (Gráfico 29). 


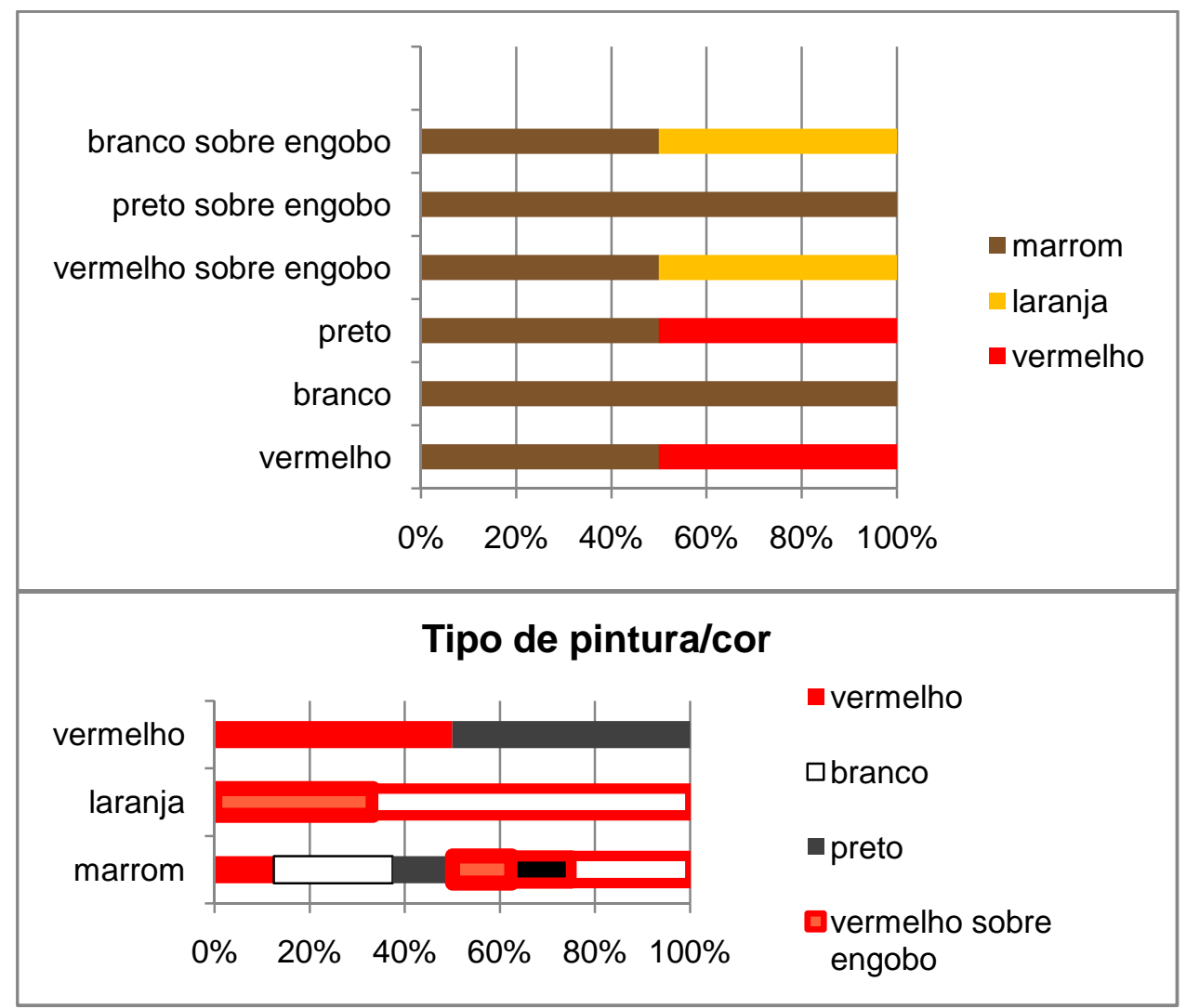

Gráfico 29: proporção de tipos com pintura entre as diferentes cores

A avaliação das diferentes cores da pasta foi interessante, na medida em que foram percebidas variações, mesmo que discretas, entre o uso destas determinadas argilas e aspectos tecnológicos, morfológicos e decorativos. Em comum a estas variações foi o comportamento da pasta amarela e vermelha, normalmente diferente em relação as outras cores ${ }^{38}$.

Os tipos mais comuns que ocorrem no sítio são relacionados às cores marrom e laranja, com cacos que demonstraram tecnologia e morfologia semelhantes, mas no tratamento de superfície e nas decorações apresentam tendências desiguais.

Em relação ao antiplástico, sua freqüência e ordenação, na pasta marrom e laranja, como vimos, os tipos B2/muito pobre e pobre, B3/ muito pobre e pobre,

\footnotetext{
${ }^{38}$ No anexo 2 , realizamos um teste entre as duas malhas aplicadas no sítio, e as duas sondagens com mais material arqueológico, relacionando diferentes atributos a fim de comparar os resultados. É interessante perceber que sob todos os níveis (escalas) analisados (tanto malhas $10 \times 10$ e $30 \times 30 \mathrm{~m}$, e sondagens) os tipos mais populares são os mesmos, marrom e laranja, com freqüência B3 e ordenação muito pobre.
} 
C3/muito pobre, representam mais de $60 \%$ das ocorrências. Nas duas o tipo $\mathrm{B} 3 /$ muito pobre é o mais freqüente. ${ }^{39}$

A morfologia, relacionada à espessura do fragmento, são muito semelhantes entre as duas cores, variando de 0,3 a 2cm, com predomínio entre 0,6-0,8 (em mais de 60\%). Mas entre as bordas existem diferenças. $O$ indicie de fragmentos do tipo direta é semelhante em ambas, mas a proporção de bordas com morfologia do tipo extrovertida e introvertida é diferente, sendo a laranja a pasta com maior tendência a ter indivíduos mais introvertidos e menos extrovertidos, enquanto que na marrom, ocorre o contrário ${ }^{40}$.

Outras diferenças estão marcadas no campo da decoração, plástica e pintada. É interessante que mais da metade dos fragmentos corrugados sejam da cor laranja, e que sua proporção de indivíduos decorados seja maior que o dobro da marrom, embora laranja não ser a mais popular no sítio. Também nesta cor, a decoração pintada só foi encontrada aliada ao engobo vermelho.

Sobre a pasta amarela, podemos considerar que esta foi utilizada de uma maneira diferente que as outras cores. Conforme pudemos relatar, estas dissimilitudes são encontradas sob diferentes aspectos tecnológicos, morfológicos e decorativos. A freqüência/ordenação do antiplástico é um exemplo, resultando como tipos predominantes aqueles que indicam menos proporção na pasta e mais homogeneidade entre os componentes, representados por A2/equilibrado (21,3\%) e A3/pobre (18\%). A espessura predominante dos fragmentos também é mais fina que as cores anteriores predominando entre 0,5 e $0,7 \mathrm{~cm}$, e as bordas extrovertidas tem a maior população em relação as demais cores. Interessante é que nesta tonalidade ocorrem raríssimos tipos decorados, ausência de pintura, engobo e polimento, e a proporção de barbotina é menor em comparação as outras pastas.

\footnotetext{
${ }^{39}$ Laranja: $32,31 \%$, Marrom 30,1\%.

40 Laranja extrovertidas: $33,68 \%$ e introvertidas: $22,1 \%$, marrom extrovertidas $45,1 \%$ e introvertidas: $7 \%$.
} 
$\mathrm{Na}$ vermelha acreditamos que sua caracterização foi prejudicada pela baixo número de indivíduos obtidos na triagem. O Tipo de freqüência/ordenação do antiplástico mais popular foi a $A 3 /$ muito pobre(31,37\%) e B3/muito pobre $(17,64 \%)$. Chama a atenção que neste tipo de cor o antiplástico tende a ser mais heterogêneo que as demais, ou seja, com componentes variando a proporção desde tamanhos muito reduzidos, a dimensões consideradas grandes com mais de $3 \mathrm{~mm}$. Os fragmentos também são mais finos, predominando espessuras de $3 \mathrm{~mm}$ até $6 \mathrm{~mm}$. Dado o número reduzido da amostra quem sabe, o numero de bordas foi muito reduzido e resultaram por conseqüência somente tipos diretos e extrovertidos. Mas ao mesmo tempo, tipos de decoração plástica como o Inciso e ungulado, e pintura, como preta e vermelha também ocorrem entre esta pequena amostra.

Os tipos de cores podem variar devido a escolha do local de coleta de matériaprima, e/ou devido aos tratamentos pré e pós cocção do pote. Durante a queima é que se definem aspectos como dureza, porosidade e a cor do fragmento. Muitas vezes as tonalidades podem refletir processos de queima e utilização, mas como vimos no caso do sitio, houve variações sob diversos aspectos entre as diferentes tonalidades de cor, levando a pensar que estas diferentes tonalidades também podem ser resultado de escolhas durante a aquisição da matéria-prima dos potes. Contudo não foi possível chegar a informações, como por exemplo, o uso de determinados tipos de argila e a construção de determinados potes. Paras estas diferenças e similitudes entre as cores chamamos a atenção, pois podem indicativos tecnológicos que contribuem na caracterização da indústria cerâmica do sitio Encontro, assunto tratado no tópico a seguir.

\subsubsection{Caracterização da indústria cerâmica do sítio Encontro.}

Na cerâmica do sitio Encontro, predominam os tipos simples, com superfícies alisadas, em $90 \%$ dos casos. Os utensílios, com antiplástico mineral (areia), presentes na pasta entre $20 \%$ a $30 \%$, eram construídos a partir da técnica do acordelamento, com espessuras predominantes entre 0,7 e $0,9 \mathrm{~cm}$, em potes 
de tamanhos variáveis - com diâmetros de boca entre $6 \mathrm{~cm}$ e $48 \mathrm{~cm}$. A espessura dos potes podem ter variado de acordo com o seu tamanho, 0 volume e a sua função (por exemplo, assadores, bordas diretas inclinadas exteriormente, tendem a ser mais grossos,).

Segundo Skibo (1992) os antiplásticos minerais permitem uma melhor efetividade térmica, e quanto menor for a dimensão destas partículas, menos chances da ocorrência de quebras ou rachaduras devido ao stress térmico dos potes quando ao fogo.

A barbotina, encontrada concomitante a metade dos tipos alisados, pode ter sido utilizada para encobrir os maiores componentes antiplásticos por vezes presentes na superfície do fragmento, assim como encobrir imperfeições, e logo, dando maior resistência ao pote, aumentando a probabilidade de sucesso entre a secagem e a queima. Este tratamento de superfície também possui propriedades impermeabilizantes. (Shepard, 1956, Rye,1987, Rice1987).

Assim como o polimento, que foi identificado em poucos casos, sempre na face interna dos fragmentos com espessura mais finas que $0,8 \mathrm{~cm}$.

A denominada teoria do design (Schiffer e Skivo, 2001) postula que determinadas propriedades do artefato (seu design) são escolhas feitas com consideração as características de performance (mecânicas, térmicas, químicas, sensoriais e visuais), sendo os vasilhames cerâmicos, utensílios preparados para determinadas funções. As escolhas realizadas, as propriedades formais $\mathrm{e}$ as características de performance formam os denominados princípios correlatos.(Machado,2006) Na pesquisa não foi possível tal nível de apreciação, mas algumas tendências relacionadas a escolhas durante o processo de fabricação dos utensílios pode ser observada. Esta apreciação é notada principalmente a partir da divisão dos fragmentos a partir da cor da pasta.

As cores laranja, marrom, amarelo e vermelho demonstraram variações que podem estar ligadas a escolha e preparação da matéria-prima cerâmica: 
Marrom: a mais freqüente, em mais de $60 \%$, possui ampla variabilidade, comportando todas as variáveis analisada, inclusive decorações plásticas e pintadas. A ocorrência de polidos é praticamente exclusiva a esta pasta, onde tipos de borda direta e extrovertidas predominam, com raríssimas introvertidas.

Laranja: Segunda mais freqüente, parece ser a escolhida para aqueles fragmentos com decoração plástica, e possuindo mais de $60 \%$ dos fragmentos corrugados. A pintura quando encontrada aqui, era aplicada somente sobre engobo vermelho.

Amarelo: A mais homogênea no quesito tratamento de superfície. Diferencia-se pela menor freqüência de antiplastico na pasta, assim como a presença de componentes mais finos que as demais cores. Não ocorrem decoração pintada, engobo ou polimento, e a barbotina, esta presente em $30 \%$, índice baixo se compararmos com outras cores. Formas mais abertas, principalmente extrovertidas.

Vermelho: Difícil caracterização. Talvez pelo seu uso mais restrito a potes com menor tamanho, indicado pela espessura dos fragmentos e pelo diâmetro da boca, nesta pasta encontramos o maior índice de cacos com algum tipo de decoração.

Como vimos, existiu a preferência de determinadas pastas (com atributos relacionados a cor,freqüência e tamanho do antiplástico ${ }^{41}$ ) para a execução de determinadas funções, não pode ser realizada, mas a estandardização de conjuntos de atributos percebidos, podem dar caráter de especialização em determinados tipos da industria.

A cerâmica do sitio também é característica pelo alto índice de formas abertas, de diretas a inclinadas externamente, a extrovertidas, em mais de $77 \%$ das bordas analisadas. Infelizmente, reconstituições de forma não foram possíveis, dado o estado erosivo do material. Mas é interessante ressaltar a alta presença de ombros nos pote e a ocorrência, apesar de pouca, de fragmentos de carenas. As formas terminavam, quando identificado, de forma plana, às vezes com uma sua angulação.

${ }^{41}$ Exemplo seria o alto índice de indivíduos com um mesmo padrão, por exemplo: marrom, $30 \%$ de antiplástico, ordenação muito pobre, laranja $30 \%$, laranja $20 \%$ amarelo $10 \%$ 
Existem tipos, que pela recorrência, consideramos típicos da indústria cerâmica do sitio Encontro. Como é o caso das bordas extrovertidas e das com reforço e decoração plástica, normalmente incisa ou ungulada.

Em relação as decoracoes plásticas percebemos a ampla variabilidade tanto horizontal quanto vertical no sitio. Contudo, nos níveis mais profundos é interessante perceber o predomínio dos tipos Corrugado e Roletado, assim como deve-se notar que as decorações pintadas estão situadas nos níveis mais superiores.(vide anexo 2)

Outra característica seriam os potes corrugados somente até o maior ponto de inflexão, fato este também observado entre os Tupi do oeste amazônico, estudado por Almeida (2008)

A caracterização da indústria cerâmica do sitio em alguma fase ou tradição arqueológica não é uma tarefa simples. Ao que tudo indica, os vestígios estariam ligados a cerâmica da tradição Tupiguarani, já identificada na área divididos em oito fases, como podemos observar no capítulos dois. Não relacionamos a cerâmica do sitio Encontro a nenhuma fase específica, dado a falta de dados comparáveis, pois aspectos importantes, como um maior detalhamento das decorações plásticas e a morfologia dos portes, por exemplo, não puderam ser realizadas.

Entendemos o termo Tupiguarani como uma referência à grande tradição arqueológica espalhada por território considerável do continente sul-americano. A idéia de unicidade da cultura material tupiguarani proporcionou vários debates acerca da origem e dispersão desses grupos nas terras baixas da América do Sul. Foram construídos alguns modelos gerais para explicar as rotas de dispersão dos grupos através da "evolução" estilística da técnica, como o de Brochado (1984) e Schmitz (1991).

A definição do termo foi explicada por Brochado (1973, p.9) da seguinte forma:

(...)La alfareria de la tradición Tupiguarani, en el momento de los primeros contactos com los europeos, fue encontrada exclusivamente entre grupos indígenas de la família linguistica Tupi-guarani, a pesar de que de ninguna manera todos los que hablavan Tupi o Guarani poseíam cerámica. Continuó después 
siendo producida y utilizada por algunos de estos grupos, com diversas variantes, desde el siglo XVI hasta el inicio del siglo XX. Por este motivo fue adoptada la designación Tupiguarani, escrita sin guión, para distinguir a la tradición alfarera de la família linguistica, cuya denominación se escribe separada por un guión Tupi-guarani.(...)

Sendo as características perceptíveis no registro arqueológico que possibilitassem enquadramento classificatório como Tupiguarani a sítios superficiais com cerâmica apresentando pintura policroma (vermelho e ou preto sobre engobo branco ou vermelho), e técnicas plásticas de acabamento preponderando o alisado, o corrugado, o ungulado, escovado, além de superfícies apenas engobadas. Seriam característicos ainda enterramentos secundários em urnas, machados de pedra polida, tembetás, lascas, talhadores e abrasadores (Chmyz, 1976; PRONAPA, 1969; Brochado, 1981).

$\mathrm{Na}$ análise foi possível observar aspectos da cerâmica Tupiguarani, como os vasos roletados, formas extrovertidas, recorrência de potes com 'ombros', carenas, policromia, engobo vermelho e decorações corrugadas predominante entre as plásticas.

Ao mesmo tempo, existem variações regionais desta cerâmica, como a utilização de um antiplástico diferente (quartzo), a raríssima ocorrência do chamote, a presença do corrugado apenas no bojo superior, assim como a alta representatividade de bordas reforçadas com incisões.

Uma melhor caracterização desta cerâmica Tupiguarani na região, dado o horizonte cronológico tão antigo que temos para o sítio Encontro, pode gerar questões relacionadas aos principais modelos de expansão deste grupo, discutido por arqueólogos, antropólogos e lingüistas, que ainda vão ser tratadas mais a fundo no próximo capítulo. 


\subsection{LÍTICO}

Como mencionado, o sítio Encontro se trata de um assentamento lito-cerâmico. Infelizmente não houve viabilidade para que se realizasse uma análise detalhada do material lítico. Portanto somente são apresentados somente comentários acerca a ocorrência de materiais arqueológicos de pedra lascada e polida.

Foram raríssimos os núcleos resultantes da escavação, a maioria do material lítico compreendia pequenas lascas unipolares e raríssimas bipolares de dimensões pequenas (até $3 \mathrm{~cm}$ ) não chegando a 300 peças em toda a coleção.

Durante a escavação foi encontrado uma lâmina-de-machado polido, parcialmente destruída, no nível $30-40 \mathrm{~cm}$, da sondagem $\mathrm{S6} \mathrm{W} 8$, e mais outro exemplar proveniente de doação com origem atribuída a superfície do sítio Encontro.

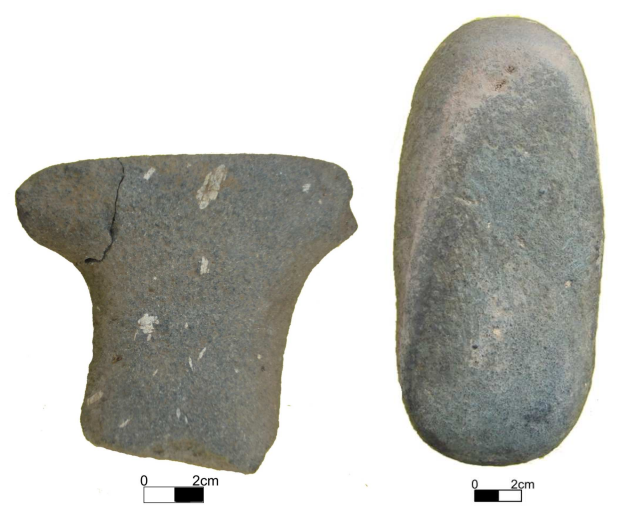

Imagem 51: a esquerda a lamina de machado resultado da escavação e a direita a da superfície.

Houve a ocorrência, de dois líticos polidos, em quartzo, identificados até o momento como adornos, possíveis pingentes, também na sondagem S6 W8. 


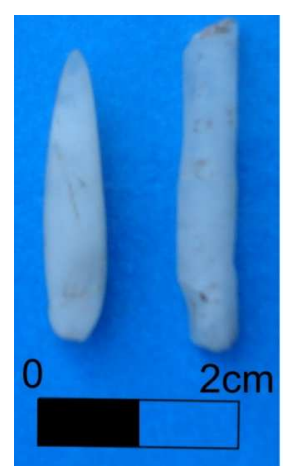

Imagem 52: líticos polidos em quartzo.

\subsection{ESTRATIGRAFIA E CRONOLOGIA}

O sítio está inserido em um relevo suave ondulado, onde em campos planos entre a encosta de topos até as vertentes ou igarapés são encontrados vestígios da ocupação pré-colonial.

A camada arqueológica predominante ocorre entre $0-30 \mathrm{~cm}$, em solo com textura areno-argilosa. A estratigrafia do assentamento foi analisada em três pontos, dois deles, caracterizados pela presença de Terra Preta Arqueológica. As avaliações foram balizadas a partir do resultado das análises de um ponto mais de $300 \mathrm{~m}$ distante do assentamento.

Foram elaboradas estratégias de coleta no intuito de reunir um número suficiente de amostras para a caracterização física e química do solo ${ }^{42}$. A amostra era retirada em cada horizonte definido pela descrição morfológica do perfil, realizadas a partir do Manual de coleta de solos em campo proposto por Lemos e Santos (2002).

Segundo Kämpf e Kern (2003) as TPA's podem ser identificadas e distinguidas dos solos vizinhos por algumas propriedades particulares, observáveis no campo (cor, espessura da camada escura, presença de cerâmica, líticos, fragmentos de carvão, textura) e, ou mensuráveis no laboratório $(\mathrm{pH}$, teor de $\mathrm{C}$

\footnotetext{
${ }^{42}$ As coletas foram realizadas nas seguintes sondagens: N4 E22 - evidência de terra preta arqueológica S49 E54 - evidência de terra preta arqueológica S74 E71 - sondagem na malha $30 \times 30 \mathrm{~m}$ com presença de material arqueológico e AD - área adjacente ao sítio arqueológico.
} 
orgânico, $\mathrm{P}, \mathrm{Ca}, \mathrm{Mg}, \mathrm{Mn}, \mathrm{Zn}$, etc.). Estas propriedades, por constituírem assinaturas antrópicas, possibilitam o estabelecimento de critérios para a identificação e a classificação específica desses solos, independentemente das classificações pedológicas formais.(idem)

Os elementos químicos analisados foram: Cálcio $(\mathrm{Ca})$, Fósforo $(\mathrm{P})$, Potássio $(\mathrm{K})$, Sódio (Na), Manganês (Mn), Magnésio(Mg) Zinco ( $\mathrm{Zn}$ ) Ferro (Fe) e Cobre (Cu)Carbono(C), mais pH e Total de Matéria Orgânica (\%M.O). A relação Carbono-Nitrogênio, o pH, também serão realizados. a fim de gerar assinaturas químicas dos diversos pontos de coleta. Segundo Kern (1996), a análise destes elementos é suficiente para responder questões relacionadas às estruturas arqueológicas encontradas, à variabilidade lateral e em profundidade, assim como a sua relação com possíveis áreas de atividade de grupos pré-históricos.

As análises físicas foram realizadas no Laboratório de Solos do Museu Paraense Emílio Goeldi, em Belém-PA, e as químicas no Departamento de Solos, da Escola Superior de Agricultura Luiz de Queiros (ESALQ-USP), em Piracicaba-SP, sendo guiada pelos procedimentos da EMBRAPA (1979), que já foi testado e aprovado pelos estudos de solo relacionados às TPA's, como em Kern (1988, 1996 e1999).

Também foi possível datar o perfil de uma das sondagens com TPA em dois pontos. Os resultados do $\mathrm{C} 14$, mais o isótopo nos auxiliaram a situar o assentamento, com dados cronológicos e possíveis dois possíveis indicadores paleoambientais.

Cabe mencionar que na região ocorrem sítios lito-cerâmicos muito próximos ao assentamento, como é caso do Carreador (RO-MA-06) a $3 \mathrm{~km}$ e Bananal (ROCA-01) a $7 \mathrm{~km}^{43}$, ambos situados em solos considerados mais ricos, e predominantes na área, o Argilossolo vermelho. (EMBRAPA,1998).

${ }^{43}$ Vide croqui da pagina 67 


\subsubsection{Registro dos dados estratigráficos}

Os três locais apontados onde houve a descrição e coleta de solo para análise foram denominados de TPA-1, TPA-2 e AD. ${ }^{44}$

A seguir podemos acompanhar a descrição morfológica dos dois pontos com TPA, assim como os resultados da textura dos horizontes pedológicos analisados.

${ }^{44}$ TPA-1 corresponde à sondagem N4 E22, TPA-2: sondagem S49 E54 e AD: área adjacente ao sítio. Vide croqui da pag 67 para conferir a localização destes pontos no sítio arqueológico 
imagem 531 tpa 
imagem 54 tpa2 
A camada com evidências arqueológicas predominante, em ambas as sondagens é areno-argilosa, e esta situada entre $0-30 / 40 \mathrm{~cm}$ de profundidade, com colorações entre 10YR 2/1 e 10YR 4/2. A incidência de fragmentos cerâmicos em cada nível artificial escavado, e entre os diferentes horizontes estabelecidos aparentam algumas diferenças em meio aos dois locais, tendo a TPA-1 uma camada arqueológica predominante de $30 \mathrm{~cm}$. Especialmente um horizonte, $A 3$, entre $20-30 \mathrm{~cm}$, há a ocorrência de $80,1 \%$ da cerâmica escavada nesta sondagem.(Tabela 9)

\begin{tabular}{ccc}
\hline & TPA 1 & \\
\hline Nível & Horizonte & Cerâmica \\
$\mathbf{0 - 1 0} \mathbf{~ c m ~}$ & A1-A2 & 4 \\
$\mathbf{1 0 - 2 0} \mathbf{~ c m}$ & A2-A3 & 94 \\
$\mathbf{2 0 - 3 0} \mathbf{~ c m}$ & A3 & 607 \\
$\mathbf{3 0 - 4 0} \mathbf{~ c m}$ & $A 3$ & 50 \\
$\mathbf{4 0 - 5 0} \mathbf{~ c m}$ & $A 4-A B$ & 8 \\
$\mathbf{5 0 - 6 0} \mathbf{~ c m}$ & $A B$ & 4 \\
\hline
\end{tabular}

Tabela 9: Quantidade de cerâmica escavada em relação aos níveis artificiais e aos horizontes pedológicos da sondagem N4 E22.

Um pouco distinto é o contexto evidenciado na TPA-2, que apresenta uma camada predominante cerâmica mais espessa e homogênea, e diferentemente a anterior, distribui-se entre mais horizontes (A1, A2 e A3), de $0-40 \mathrm{~cm}$ de profundidade.

\begin{tabular}{ccc}
\hline & TPA - 2 \\
\hline nível & Horizonte & Cerâmica \\
$0-10 \mathrm{~cm}$ & A1 & 104 \\
$10-20 \mathrm{~cm}$ & A2 & 172 \\
$20-30 \mathrm{~cm}$ & A2 & 129 \\
$30-40 \mathrm{~cm}$ & A3 & 105 \\
$40-50 \mathrm{~cm}$ & A3 & 20 \\
$50-60 \mathrm{~cm}$ & A3/BA & 32 \\
$60-70 \mathrm{~cm}$ & BA/B1 & 8 \\
\hline
\end{tabular}

Tabela 10: Quantidade de cerâmica escavada em relação ao níveis artificiais e os horizontes pedológicos da TPA-2 
$\mathrm{Na}$ área adjacente ao sítio e no próprio assentamento ocorre a predominância de solos muito arenosos (entre $60-70 \%$ ), de 0 a $50 / 60 \mathrm{~cm}$ de profundidade.

\begin{tabular}{cccccc}
\hline Horizonte & Profundidade & Areia Grossa & Areia Fina & Argila & Silte \\
\hline A1 & $0-10 \mathrm{~cm}$ & 50 & 18 & 20 & 12 \\
A2 & $10-20 \mathrm{~cm}$ & 41 & 18 & 24 & 17 \\
AB & $20-39 \mathrm{~cm}$ & 43 & 20 & 20 & 17 \\
BA & $39-55 \mathrm{~cm}$ & 24 & 11 & 45 & 20 \\
B1 & $55-79 \mathrm{~cm}$ & 40 & 13 & 30 & 17 \\
B2 & $79-100 \mathrm{~cm}+$ & 38 & 18 & 27 & 17 \\
\hline
\end{tabular}

Tabela 11: textura dos solos na área adjacente (valores em porcentagem).

$\mathrm{Na}$ avaliação dos perfis de solo do interior do sítio (TPA-1 e TPA-2) em relação a área adjacente $(A D)$, pode-se verificar que nas TPA's o solo apresenta entre três a quatro horizontes $A$, com coloração mais escura e maior espessura $( \pm 50 \mathrm{~cm})$ enquanto que na $A D$ apenas dois, mais delgados e com coloração mais clara. Esta é uma característica marcante já que os horizontes $A$ das TPA's estão relacionados a camada de ocupação do sítio.

A espessura dos horizontes de transição das TPA's variou, em $A B$ e BA na TPA-1, entre $46-79 \mathrm{~cm}$, e BA na TPA-2, entre $56-68 \mathrm{~cm}$. Na área adjacente, assim como na TPA-2 tem-se dois horizontes de transição, só que ocorrem mais acima em relação às TPA's (entre $20-55 \mathrm{~cm}$ ).

Os horizontes $B$, tanto nas TPA's quanto na $A D$, não apresentaram variações significativas em relação a morfologia do solo. Estao situadas em profundidades semelhantes, na AD a partir de $55 \mathrm{~cm}$ e nas TPA's a partir de $68 \mathrm{~cm}$, com coloração semelhantes (2,5YR 4/8 e 5/8), argilosas e com estrutura forte a aspecto maciço.

As características físicas e morfológicas do solo, assim como sua inserção na paisagem, nos levam a crer que os solos do interior do sítio arqueológico e da área adjacente pertenciam a uma mesma classe antes da ocupação humana.

\subsubsection{Análises Químicas}

Ambas evidências de TPA são características por apresentarem o denominado horizonte A de coloração mais escura (10 YR 4/2, dark graysh Brown, 10YR 
2/1, Black) particularidade deste tipo de solo, indicadas por Kämpf e Kern (2003). As diferenças físicas e morfológicas entre os dois pontos não são poucas, assim como a situação estratigráfica da cerâmica, sua freqüência, e a composição química dos horizontes pedológicos, como veremos a seguir.

Geralmente, as terras pretas são caracterizadas pelo alto valor do $\mathrm{pH}$. (Kern, 1996, Woods, 2003, Kern et. al., 2004). A TPA-1 apresentou o valor mais alto dentro do sítio. No outro caso, TPA-2, no entanto, os valores ficaram mais próximos do que foi indicado para a $A D$, também considerando alto. (Tabela 12). Os dados para dentro do sítio podem ser explicados de significante presença de cátions com reação básica em água, presente em $\mathrm{Ca}, \mathrm{Mg}, \mathrm{K}$ e $\mathrm{Na}$.

\begin{tabular}{|c|c|c|c|c|c|c|c|c|c|c|c|}
\hline \multicolumn{12}{|c|}{$\mathrm{pH}$} \\
\hline \multicolumn{4}{|c|}{ AD } & \multicolumn{4}{|c|}{ TPA-1 } & \multicolumn{4}{|c|}{ TPA-2 } \\
\hline & nível & $\mathrm{H}_{2} \mathrm{O}$ & $\mathrm{KCl}$ & & nível & $\mathrm{H}_{2} \mathrm{O}$ & KC & & nível & $\mathrm{H}_{2} \mathrm{O}$ & $\mathrm{KCl}$ \\
\hline A1 & $0-10 \mathrm{~cm}$ & 5,9 & 4,6 & A1 & $0-7 / 8 \mathrm{~cm}$ & 6,3 & 4,6 & A1 & $0-12 \mathrm{~cm}$ & 5,1 & 4,5 \\
\hline A2 & $10-20 \mathrm{~cm}$ & 6 & 4,5 & $\mathrm{~A} 2$ & $\begin{array}{c}7 / 8- \\
12 / 13 \mathrm{~cm}\end{array}$ & 7 & 5 & A2 & $12-29 \mathrm{~cm}$ & 5,4 & 4,6 \\
\hline$A B$ & $20-39 \mathrm{~cm}$ & 5,9 & 4,5 & A3 & $\begin{array}{l}12 / 13- \\
34 / 37 \mathrm{~cm}\end{array}$ & 6,2 & 5,1 & A3 & $29-54 \mathrm{~cm}$ & 5,5 & 4,7 \\
\hline BA & $39-55 \mathrm{~cm}$ & 6,1 & 4,5 & A4 & $\begin{array}{c}34 / 37- \\
47 \mathrm{~cm}\end{array}$ & 6,9 & 5,1 & BA & $54-68 \mathrm{~cm}$ & 6,2 & 5,2 \\
\hline B1 & $55-79 \mathrm{~cm}$ & 6 & 4,8 & $A B$ & $47-63 \mathrm{~cm}$ & 6,4 & 5,1 & B1 & $68-85 \mathrm{~cm}$ & 6,1 & 5,7 \\
\hline \multirow[t]{3}{*}{ B2 } & $\begin{array}{c}79- \\
100 \mathrm{~cm}+\end{array}$ & 6 & 5,2 & BA & $63-79 \mathrm{~cm}$ & 6,8 & 5,2 & B2 & $85-130 \mathrm{~cm}$ & 6,2 & 5,8 \\
\hline & & & & B1 & $\begin{array}{c}79- \\
107 \mathrm{~cm}\end{array}$ & 6,5 & 5,5 & & $0-12 \mathrm{~cm}$ & & \\
\hline & & & & B2 & $\begin{array}{c}107- \\
150+\mathrm{cm}\end{array}$ & 6,9 & 6 & & $12-29 \mathrm{~cm}$ & & \\
\hline
\end{tabular}

Pesquisas em solos de TPA, em diversas áreas, sugerem sua alta fertilidade em relação aos solos vizinhos, e logo valores mais elevados de elementos químicos como $\mathrm{P}, \mathrm{Na}, \mathrm{K}, \mathrm{Ca}, \mathrm{Mg}$, são esperados nestes solos antrópicos.

O fósforo $(\mathrm{P})$ geralmente é referido dado a sua estirpe antropogênica. Juntamente com o cálcio $(\mathrm{Ca})$ podem indicar elementos de origem animal adicionados ao solo, tanto sangue, como ossos são altamente ricos nestes elementos. 
Estudos indicam que o acúmulo de resíduos de origem vegetal e animal, podem causar o aumento nos níveis de fósforo $(\mathrm{P})$, cálcio(Ca), e magnésio(Mg). Os altos índices de potássio $(\mathrm{K})$ quando encontrados podem ter relação com atividades de queima, cinzas, além da presença de outros materiais de origem orgânica como couro,pêlos, etc. que resultariam no aumento significativo no valor deste elemento.

$\mathrm{Na}$ tabela a seguir podemos acompanhar os valores obtidos nas análises químicas dos horizontes de cada sondagem com TPA e na área adjacente ao sítio arqueológico.

\begin{tabular}{|c|c|c|c|c|c|c|c|}
\hline TPA-1 & & M.O. & $\mathbf{P}$ & $\mathrm{Na}$ & $\mathbf{K}$ & $\mathrm{Ca}$ & $\mathbf{M g}$ \\
\hline & nível & g. $\mathrm{kg}^{-1}$ & $\mathrm{mg} \cdot \mathrm{kg}^{-1}$ & \multicolumn{4}{|c|}{ mmolc.kg $^{-1}$} \\
\hline A1 & $0-7 / 8 \mathrm{~cm}$ & 31 & 86 & 0,4 & 4 & 56 & 20 \\
\hline A2 & $7 / 8-12 / 13 \mathrm{~cm}$ & 27 & 126 & 0,3 & 3,6 & 50 & 16 \\
\hline A3 & $12 / 13-34 / 37 \mathrm{~cm}$ & 23 & 61 & 0,3 & 2,6 & 36 & 11 \\
\hline A4 & $34 / 37-47 \mathrm{~cm}$ & 12 & 27 & 0,3 & 1,5 & 13 & 5 \\
\hline$A B$ & $47-63 c m$ & 10 & 35 & 0,2 & 1,9 & 14 & 5 \\
\hline BA & $63-79 \mathrm{~cm}$ & 10 & 31 & 0,3 & 3,2 & 17 & 7 \\
\hline B1 & $79-107 \mathrm{~cm}$ & 10 & 18 & 0,4 & 5,3 & 17 & 9 \\
\hline B2 & $107-150+\mathrm{cm}$ & 8 & 2 & 0,3 & 7,8 & 12 & 6 \\
\hline
\end{tabular}

\begin{tabular}{|c|c|cc|cccc|}
\hline TPA-2 & & M.O. & $\mathbf{P}$ & $\mathbf{N a}$ & $\mathbf{K}$ & $\mathbf{C a}$ & $\mathbf{M g}$ \\
\hline & nivel & $\mathbf{g} \cdot \mathbf{k g}^{-1}$ & $\mathbf{m g} \cdot \mathbf{k g}^{-1}$ & \multicolumn{4}{|c|}{ mmolc.kg $^{-1}$} \\
\hline A1 & $\mathbf{0 - 1 2} \mathbf{~ c m}$ & 40 & 25 & 0,5 & 3,2 & 42 & 11 \\
A2 & $\mathbf{1 2 - 2 9 \mathbf { c m }}$ & 24 & 18 & 0,3 & 0,8 & 20 & 3 \\
A3 & $\mathbf{2 9 - 5 4 \mathbf { c m }}$ & 14 & 4 & 0,2 & 0,3 & 13 & 1 \\
BA & $\mathbf{5 4 - 6 8 c m}$ & 10 & 3 & 0,2 & 0,4 & 10 & 1 \\
B1 & $\mathbf{6 8 - 8 5 c m}$ & 10 & 3 & 0,2 & 0,8 & 20 & 2 \\
B2 & $\mathbf{8 5 - 1 3 0 c m}$ & 9 & 2 & 0,3 & 1,3 & 20 & 3 \\
\hline
\end{tabular}

\begin{tabular}{|c|ccc|cccc|}
\hline AD & & M.O. & $\mathbf{P}$ & $\mathbf{N a}$ & $\mathbf{K}$ & $\mathbf{C a}$ & $\mathbf{M g}$ \\
\hline & nível & $\mathbf{g . k g}^{-1}$ & $\mathbf{m g}^{-k_{g}} \mathbf{~}^{-1}$ & \multicolumn{4}{c|}{ mmolc.kg $^{-1}$} \\
\hline A1 & $0-10 \mathrm{~cm}$ & 36 & 8 & 0,2 & 1,4 & 20 & 4 \\
A2 & $10-20 \mathrm{~cm}$ & 26 & 6 & 0,3 & 0,7 & 16 & 3 \\
AB & $20-39 \mathrm{~cm}$ & 16 & 4 & 0,2 & 0,5 & 18 & 2 \\
BA & $39-55 \mathrm{~cm}$ & 12 & 3 & 0,2 & 0,4 & 13 & 2 \\
B1 & $55-79 \mathrm{~cm}$ & 11 & 2 & 0,2 & 0,4 & 15 & 2 \\
B2 & $79-100 \mathrm{~cm}+$ & 9 & 1 & 0,2 & 0,5 & 16 & 4 \\
\hline
\end{tabular}

Tabela 13: valores de M.O., P, Na, K, Ca, Mg. FS: fora do sítio 
Os índices de matéria orgânica (M.O) verificados nas duas TPA's aparentam um ligeiro aumento em relação ao encontrado fora do sítio. Observamos que a partir de $20 \mathrm{~cm}$ de profundidade, fora do assentamento, tem-se um diminuição dos valores, enquanto que na TPA isto ocorre um pouco mais abaixo, a partir de $30 / 37 \mathrm{~cm}$.

Na TPA-1 obtemos os maiores valores nos elementos químicos mencionados na tabela acima - todos com valores são superiores em relação a fora do sítio. Destacam-se P e K, por apresentarem índices muito elevados, e que persistem até horizontes mais profundos.

No outro ponto (TPA-2) as variações em relação a área adjacente não são tão superiores em $\mathrm{P}, \mathrm{Ca}$, enquanto que nos demais elementos $(\mathrm{Na}, \mathrm{K}, \mathrm{Mg})$ há uma nítida superioridade no horizonte $A$, afetado pela ocupação humana.

As terras pretas em muitos casos, não apresentam Al trocável, sendo relacionado ao alto teor de $\mathrm{Ca}$ e $\mathrm{Mg}$ também presentes. $\mathrm{O}$ teor de $\mathrm{Al}$ é relacionado com a M.O., isto é, com o aumento da M.O. pela atividade humana. $\mathrm{O}$ valor $\mathrm{SB}^{45,} \mathrm{~T}^{46} \mathrm{e} \mathrm{V} / \mathrm{m}^{47} \mathrm{em}$ geral possuem índices muito elevados nas TPA's, sendo dados indicadores da alta fertilidade apresentada em relação aos solos vizinhos. (Kämpf et. al. 1998, Kern et. al. 2004). O valor $\mathrm{V} / \mathrm{m}$ acima de $50 \%$ determina solos eutróficos e abaixo, solos distróficos, e sendo assim, nos horizontes A os solos das TPAs são considerados eutróficos, com alta fertilidade decorrentes da ocupação humana no passado. Enquanto que na $A D$ ocorre o inverso, provavelmente tendo a ver com o material de origem que já deveria ter valores elevados de trocáveis.(Kern, com. pessoal).

Na observação destes valores temos uma evidente superioridade nos índices dentro do sítio arqueológico. (Tabela 13).

\footnotetext{
${ }^{45}$ soma de $\mathrm{Ca}, \mathrm{Mg}, \mathrm{K}$,

${ }^{46}$ valor T é a soma de todos os cátions ( $\left.\mathrm{Ca}, \mathrm{Mg}, \mathrm{K}\right)$, e Al e $\mathrm{H}$.

${ }^{47}$ valor $\mathrm{V} / \mathrm{m}$ A porcentagem de cátions básicos $(\mathrm{Ca}, \mathrm{Mg}, \mathrm{K})$ em relação ao valor $\mathrm{T}$ (todos os cátions, Al e H)
} 


\begin{tabular}{|c|c|cccc|cc|}
\hline TPA-1 & \multicolumn{1}{c}{ Al } & H+Al & SB & T & V & m \\
\hline & nível & \multicolumn{5}{c|}{ mmolc.kg $^{-1}$} & \multicolumn{2}{c|}{$\%$} \\
\hline A1 & $0-7 / 8 c m$ & 2 & 40 & 80,4 & 120,4 & 67 & 2 \\
A2 & $7 / 8-12 / 13 \mathrm{~cm}$ & 0 & 39 & 69,9 & 108,9 & 64 & 0 \\
A3 & $12 / 13-34 / 37 \mathrm{~cm}$ & 0 & 29 & 49,9 & 78,9 & 63 & 0 \\
A4 & $34 / 37-47 \mathrm{~cm}$ & 0 & 8 & 19,9 & 27,8 & 71 & 0 \\
AB & $47-63 \mathrm{~cm}$ & 0 & 8 & 21,1 & 29,1 & 73 & 0 \\
BA & $63-79 \mathrm{~cm}$ & 0 & 9 & 27,5 & 36,5 & 75 & 0 \\
B1 & $79-107 \mathrm{~cm}$ & 0 & 10 & 31,7 & 41,7 & 76 & 0 \\
B2 & $107-150+\mathrm{cm}$ & 0 & 4 & 26,1 & 30,1 & 87 & 0 \\
\hline
\end{tabular}

\begin{tabular}{|c|c|c|c|c|c|c|c|}
\hline TPA-2 & & Al & $\mathrm{H}+\mathrm{Al}$ & SB & $\mathbf{T}$ & V & $\mathbf{m}$ \\
\hline & nível & \multicolumn{4}{|c|}{ mmolc. $\mathrm{kg}^{-1}$} & \multicolumn{2}{|c|}{$\%$} \\
\hline A1 & $0-12 \mathrm{~cm}$ & 3 & 49 & 56,7 & 105,7 & 54 & 5 \\
\hline A2 & $12-29 \mathrm{~cm}$ & 3 & 35 & 24,1 & 59,1 & 41 & 11 \\
\hline A3 & $29-54 \mathrm{~cm}$ & 2 & 20 & 14,5 & 34,5 & 42 & 12 \\
\hline BA & $54-68 \mathrm{~cm}$ & 0 & 9 & 11,6 & 20,6 & 56 & 0 \\
\hline B1 & $68-85 \mathrm{~cm}$ & 0 & 7 & 23 & 30 & 77 & 0 \\
\hline B2 & $85-130 \mathrm{~cm}$ & 0 & 9 & 24,6 & 33,6 & 73 & 0 \\
\hline
\end{tabular}

\begin{tabular}{|l|c|cccc|cc|}
\hline AD & & Al & H+Al & SB & T & \multicolumn{2}{|c|}{ V } \\
\hline & nível & \multicolumn{4}{|c|}{ mmolc.kg $^{-1}$} & \multicolumn{2}{c|}{$\%$} \\
\hline A1 & $0-10 \mathrm{~cm}$ & 3 & 40 & 25,9 & 65,9 & 39 & 10 \\
A2 & $10-20 \mathrm{~cm}$ & 4 & 27 & 20 & 47 & 43 & 17 \\
AB & $20-39 \mathrm{~cm}$ & 4 & 18 & 20,7 & 38,7 & 53 & 16 \\
BA & $39-55 \mathrm{~cm}$ & 3 & 14 & 15,6 & 29,6 & 53 & 16 \\
B1 & $55-79 \mathrm{~cm}$ & 2 & 10 & 17,6 & 27,6 & 64 & 10 \\
B2 & $79-100 \mathrm{~cm}+$ & 0 & 12 & 20,9 & 32,9 & 64 & 0 \\
\hline
\end{tabular}

Tabela 14 : resultado dos valores de Al, $\mathrm{H}+\mathrm{Al}, \mathrm{SB}, \mathrm{T}, \mathrm{V}, \mathrm{m}$

$\mathrm{Na}$ análise dos microelementos $(\mathrm{B}, \mathrm{Cu}, \mathrm{Fe}, \mathrm{Mn}, \mathrm{Zn})$ o comportamento dos valores não seguiu, digamos assim, a mesma tendência dos elementos analisados anteriormente. Apesar de ter diferenças na densidade de vestígios arqueológicos, e ter elementos que indicam uma maior fertilidade de um dos dois pontos de TPA estudados, os dados vinculados a análise dos microelementos apontaram paridade entre os dois pontos com TPA. Kern (1996) e Kern et. al. $(1999,2004)$ associam o alto índice de Zn, Mn e Cu com a presença de vegetais, como a palmeira e a mandioca, que são ricos nestes elementos, e conhecidos na etno-história pela ampla utilização na construção 
de casas e na alimentação, sendo prováveis responsáveis, em grande parte, no enriquecimento dos valores destes elementos no registro arqueológico.

A literatura também sugere que atividades como a carneação e o processamento de carne, que resultam na ocorrência de sangue, secreções, etc. no local aumentam o valor de ferro $(\mathrm{Fe})$, manganês $(\mathrm{Mn})$ e zinco $(\mathrm{Zn})$. (Kampf, et. al. 2003)

No sítio são significativos os valores de $\mathrm{Fe}$ e $\mathrm{Cu}$, mas principalmente de $\mathrm{Mn}$, na camada A2 da TPA-2. Proporcionalmente, como já mencionado, esta sondagem apresenta menos material arqueológico, além de menores valores relativos a $\mathrm{P}, \mathrm{Ca}, \mathrm{K}, \mathrm{Na}$, no entanto os índices destes elementos ( $\mathrm{Fe}, \mathrm{Cu}$ e $\mathrm{Mn}$ ), estão muito próximos da sondagem TPA-1, com ocorrência muito maior de cerâmica.

Os elementos $\mathrm{Zn}$ e $\mathrm{Mn}$ apresentaram valores significativamente superiores nos horizontes $\mathrm{A}$ das TPAs em relação aos horizontes $\mathrm{B}$ e a área adjacente.

\begin{tabular}{|c|c|c|c|c|c|c|}
\hline TPA-1 & & B & $\mathrm{Cu}$ & $\mathrm{Fe}$ & Mn & $\overline{Z n}$ \\
\hline & nível & \multicolumn{5}{|c|}{$\mathrm{mg} \mathrm{dm}^{-3}$} \\
\hline A1 & $0-7 / 8 \mathrm{~cm}$ & - & 2,2 & 238 & 33,2 & 18,1 \\
\hline A2 & $7 / 8-12 / 13 \mathrm{~cm}$ & - & 2,8 & 142 & 64,8 & 12,3 \\
\hline A3 & $\begin{array}{l}12 / 13 \\
34 / 37 \mathrm{~cm}\end{array}$ & 0,13 & 3,5 & 95 & 66,8 & 6,1 \\
\hline A4 & $34 / 37-47 \mathrm{~cm}$ & - & 1,5 & 52 & 40,9 & 1,9 \\
\hline$A B$ & $47-63 \mathrm{~cm}$ & - & 1 & 52 & 36,4 & 1,6 \\
\hline BA & $63-79 \mathrm{~cm}$ & - & 0,5 & 23 & 14,8 & 0,8 \\
\hline B1 & $79-107 \mathrm{~cm}$ & - & 0,2 & 5 & 1,9 & 0,3 \\
\hline B2 & $107-150+\mathrm{cm}$ & - & 0,1 & 2 & 0,6 & 0,2 \\
\hline \multirow[t]{2}{*}{ TPA-2 } & & B & $\mathrm{Cu}$ & $\mathrm{Fe}$ & Mn & $Z \mathbf{n}$ \\
\hline & nível & \multicolumn{5}{|c|}{$\mathrm{mg} \mathrm{dm}^{-3}$} \\
\hline A1 & $0-12 \mathrm{~cm}$ & 0,19 & 1,9 & 277 & 119,6 & 17,5 \\
\hline A2 & $12-29 \mathrm{~cm}$ & - & 1,4 & 135 & 101,8 & 2,2 \\
\hline A3 & $29-54 \mathrm{~cm}$ & 0,1 & 1,2 & 18 & 24,5 & 1,4 \\
\hline BA & $54-68 \mathrm{~cm}$ & 0,11 & 0,4 & 28 & 19,2 & 0,4 \\
\hline B1 & $68-85 \mathrm{~cm}$ & - & - & 27 & 12,6 & 0,3 \\
\hline B2 & $85-130 \mathrm{~cm}$ & - & - & 8 & 2,8 & 0,2 \\
\hline
\end{tabular}




\begin{tabular}{|l|c|ccccc|}
\hline AD & & B & Cu & Fe & Mn & Zn \\
\hline & nível & \multicolumn{5}{|c|}{$\mathbf{m g ~ d m}^{-3}$} \\
A1 & $0-10 \mathrm{~cm}$ & - & 0,5 & 144 & 53,7 & 2 \\
A2 & $10-20 \mathrm{~cm}$ & - & 0,3 & 91 & 31,8 & 0,6 \\
BB & $20-39 \mathrm{~cm}$ & 0,2 & 0,3 & 47 & 17,6 & 0,5 \\
B1 & $39-55 \mathrm{~cm}$ & - & 0,1 & 22 & 6,4 & 0,2 \\
B2 & $55-79 \mathrm{~cm}$ & - & - & 31 & 8,8 & 0,3 \\
\hline
\end{tabular}

Tabela 15: valores de B, Cu, Fe, Mn, Zn

Os teores de elementos com $\mathrm{Ca}$ e $\mathrm{Mg}$, nas primeiras camadas dos perfis dentro do sítio podem ser efeito de atividades que resultassem matéria orgânica como: ossos, vegetais diversos, couro, pêlos, penas, cinza, carvão,etc., ocorrendo, como observamos, com maior intensidade na TPA-1. Esta amplitude também está atestada nos demais elementos químicos analisados na sondagem, principalmente nas primeiras camadas, vinculadas a terra preta. Ao mesmo tempo, em horizontes subseqüentes a TPA, apresentaram níveis mais elevados que em relação a fora do sítio. Exemplo deste fato seria o elemento fósforo $(P)$, que mesmo a $79 \mathrm{~cm}$ de profundidade atingiu $31 \mathrm{mg} \cdot \mathrm{kg}^{-1}$, índice considerado alto para o local.

Woods (1977) considera que a partir da quantidade de fósforo, pode-se esboçar a intensidade e duração da ocupação de um sítio arqueológico. O enriquecimento do fósforo nos horizontes arqueológico estaria diretamente ligado ao consumo, produzindo vestígios de: ossos, excrementos, restos de alimentação, artefatos em material vegetal, etc. (Woods 2003). Aparentemente, no caso do sítio, parece haver uma proporção em relação à quantidade de cerâmica, por exemplo, e o nível de P. Na TPA-1 há muito mais $\mathrm{P}$ disponível, em todas as camadas, assim como há muito mais fragmentos cerâmicos em relação a TPA-2.

Outra característica comum em TPA's, esta encontrada em ambos os locais, foi o valor de $\mathrm{Ca}$ mais elevado que $\mathrm{Mg}, \mathrm{K}$ e $\mathrm{Na}$, que acontece devido a maior capacidade de troca de cátions do solo. (cf. Kern et.al.2004).

Na TPA-2 os valores dos elementos $\mathrm{P}, \mathrm{Ca}, \mathrm{K}$ e Na são mais modestos, sendo comparáveis ao encontrado fora do sítio. Ficam numa posição adversa aos índices de $\mathrm{Cu}, \mathrm{Fe}, \mathrm{Mn}, \mathrm{Zn}$ dos mesmos horizontes. Quem sabe a diferença 
entre os resultados esteja relacionada à dinâmica ocorrida dentro do assentamento, já que como apontamos, a importância dada a estes elementos na formação da TPA, e sua possível relação com vegetais importante como a mandioca e a palmeira (Kern et. al. 2004). Os altos índices apresentados no local destacam-se $\mathrm{Mn}$ e Fe, que alcançaram superioridade em relação à outra ocorrência de TPA.

Nesse sentido, entre as diferenças em meio aos dois pontos de Terra Preta Arqueológica, percebemos que na TPA-1 a concentração cerâmica corrobora que a camada arqueologia predominante esta enterrada pelo menos $10 \mathrm{~cm}$, e logo, possui um nível inicial $(0-10 \mathrm{~cm})$ com rara ocorrência de material arqueológico $^{48}$. Além deste fato, somam-se os indicativos das análises químicas da camada $A 2$, abaixo de $0-10 \mathrm{~cm}$, que em vezes são superiores a camada superior.

Distingui-se deste cenário o contexto encontrado na TPA-2, onde a composição estratigráfica, desde o primeiro nível $(0-10 \mathrm{~cm})(\mathrm{A} 1)$, apresenta abundância de material arqueológico, assim como são elevados a maioria dos elementos analisados na química. Talvez aqui, o denominado horizonte órtico, fosse muito delgado, e possa ter sido erodido durante os procedimentos de escavação e logo não registrado no perfil estratigráfico.

Mesmo assim, diferenças na distribuição da cerâmica que comporão cada camada estratigráfica, além de significativas mudanças nas assinaturas químicas do solo, nos levam a crer que houve dissimilitudes no processo de formação do sítio em cada parte, podendo ser decorrente da dinâmica interna do assentamento diferentes, ou a diferentes agentes perturbativos atuando em cada local, pois é notável a variabilidade espacial encontrada na concentração dos valores de elementos químicos que são tipicamente associados a TPA.

A premissa básica das análises químicas de solo é que diferentes atividades, desenvolvidas em um mesmo local, por um determinado período de tempo, deixam impressas diferentes assinaturas químicas. Estes resíduos químicos podem se manter relativamente estáveis durante séculos, ao contrário dos 48 Somente quatro fragmentos cerâmicos, todos com menos de dois centímetros de
comprimento. 
outros vestígios com que o arqueólogo trabalha, mais passíveis ao tempo e a erosão. A distribuição espacial de elementos fixados no solo, digamos assim, não sofre tanto com os processos culturais que inferem na formação do registro arqueológico.

Entretanto, esses não são valores tão elevados como aqueles encontrados em outras TPA's da Amazônia, onde teores de P chegam facilmente a 100 mg. $\mathrm{kg}^{-1}$; Mn $70 \mathrm{mg} \mathrm{dm}^{-3}$ e o Zn $5 \mathrm{mg} / \mathrm{dm}^{-3}$, (Kern, com. pessoal)

\subsubsection{Cronologia e indicadores paleoambientais}

Para dois locais da camada A3, na sondagem S49 E54 (TPA-2), foram obtidas duas datações radiocarbônicas a partir de amostras de carvão retiradas de níveis cerâmicos contendo TPA. A primeira, entre o nível $40-50 \mathrm{~cm}$, estava situada em uma porção mais profunda da camada $A 3$, que é abundante em cerâmica $O$ resultado da datação não calibrada foi:

\begin{tabular}{cccccc}
\hline Sondagem & Nível & Amostra & NoLaboratório & $\begin{array}{c}\text { Datação não } \\
\text { calibrada }\end{array}$ & $\begin{array}{c}\text { Datação calibrada } \\
\text { (2 sigma) }\end{array}$ \\
\hline S49 E54 & $40-50 \mathrm{~cm}$ & Carvão & Beta-230197 & $3850 \pm 80$ & $4255 \pm 185$ \\
S49 E54 & $60-70 \mathrm{~cm}$ & Carvão & Beta-230198 & $3970 \pm 70$ & $4425 \pm 200$ \\
\hline
\end{tabular}

Tabela 16: Resultado das datações radiocarbônicas obtidas na sondagem S49 E54

A segunda amostra, mais profunda, foi coletada no inicio do nível $60-70 \mathrm{~cm}$, em uma parte entre as camadas A3 e BA, limítrofe entra a TPA e a mudança de coloração do sedimento do horizonte seguinte, o BA. ${ }^{49}$

Com os resultados calibrados (2 sigma), a partir do aplicativo Calib 5.1b (curva InterCal04.c14) obtêm-se uma cronologia ainda mais recuada, entre $4255 \pm 185$ e $4425 \pm 200 \mathrm{AP}^{50}$.

\footnotetext{
49 O carvão estava presente entre $20-70 \mathrm{~cm}$. Novas datações de mais pontos do perfil ainda serão realizadas. Duas datações por termoluminescência a partir de fragmentos cerâmicos estão sendo processadas.

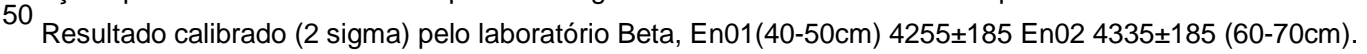




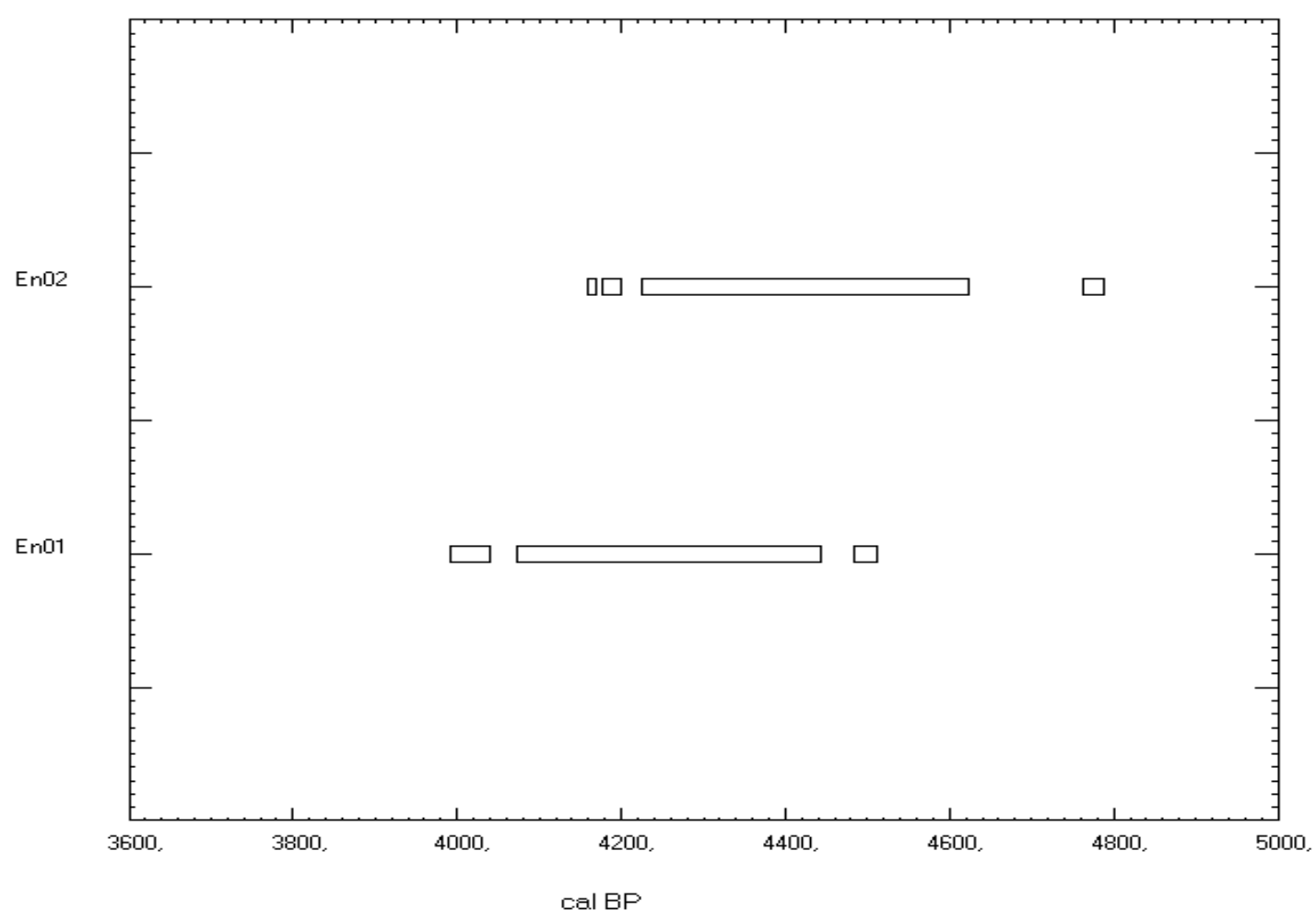

Gráfico 30: Datações calibradas no aplicativo Calib 5.1 (intercal04.c14)

\subsubsection{Isótopos do carbono $\left({ }^{12} \mathrm{C},{ }^{13} \mathrm{C}\right)$}

Estudos sobre a dinâmica floresta-campo durante o período final do quaternário foram aplicados com sucesso no sudoeste amazônico, como apresentado no capitulo 1 (Pessenda et al., 2001, Freitas et al., 2001, Gouveia, 1996). A partir de sucessivas pesquisas utilizando os dados dos isótopos do carbono da matéria orgânica do solo, os pesquisadores concluem que tal método fornece registros suficientes para a determinação de espécies de plantas entre tipos típicos de floresta $\left(\mathrm{C}_{3}\right)$ e/ou de savana $\left(\mathrm{C}_{4}\right)$. As plantas do tipo $\mathrm{C}_{3}$ (floresta) possuem valores isotópicos $\left(\delta_{13} C\right)$ mais empobrecidos, entre $-20,0 \%$ e $-32,0 \%$, enquanto que as espécies $C_{4}$ (savana) possuem índices de $\delta_{{ }_{13}} \mathrm{C}$ mais enriquecidos, ficando entre $-9,0 \%$ o $-17,0 \%$, Plantas $\mathrm{C}_{3}$ e $\mathrm{C}_{4}$ possuem valores de $\delta_{13} \mathrm{C}$ distintos que diferem de, aproximadamente, 14,0\% entre si (Boutton, 1991) 
Os valores dos isótopos de carbono $\left(\delta^{13} \mathrm{C}\right)$ obtidos no resultado da datação radiocarbônica $\left({ }^{14} \mathrm{C}\right)$ na sondagem S49 E54 foram:

$$
\begin{aligned}
& \begin{array}{cc}
\hline \text { Nível } & \delta^{13} \mathrm{C} \\
\hline \mathbf{4 0 - 5 0 c m} & -24,5 \% \text { 。 }
\end{array} \\
& 60-70 \mathrm{~cm}-28,7 \%
\end{aligned}
$$

Entre $60-70 \mathrm{~cm}$ e $40-50 \mathrm{~cm}$ observa-se um enriquecimento isotópico, onde valores de $\delta 13 \mathrm{C}$ ficaram entre $-24,5 \%$ e $-28,7 \%$, sendo indicativo para a presença de Floresta (plantas C3, Tabela 16).

Os dados de isótopos estáveis do ${ }_{13} \mathrm{C}$ ( $(\delta 13 \mathrm{C})$ aliados aos problemas arqueológicos fornecem informações, apesar de pontuais, que comprovariam a presença da Floresta neste período (4400-4200 anos AP), e logo um clima que comporte tal floresta, ou seja, já mais úmido relacionado ao optimum climaticum, iniciado na área, segundo Miller (1983) a partir de 5500 anos AP.

Estas são as primeiras evidências de ocupação para a área, que como demonstramos, tem uma alta ocorrência de sítios arqueológicos. Embora não seja a evidência lito-cerâmica mais antiga no Estado, a cronologia atribuída ao assentamento é interessante, na medida em que são escassos os dados vinculados ao Holoceno-médio na área, e sobretudo se compararmos com a região amazônica. Além disso, as características de sua cultura material podem colocar o assentamento no centro de discussão sobre as primeiras evidências da cerâmica Tupiguarani na Amazônia. Datas mais antigas nesta área não seriam assim tão surpreendentes, dado o contexto, por exemplo, dos dados lingüísticos, que ainda vamos trabalhar. As primeiras expansões Tupi estariam situadas em algum ponto próximo a Jiparaná-RO, há aproximadamente 5000 anos AP.(Migliazza, 1982) Além disso, a botânica traz dados que podem ser relacionados, como em Olsen e Schaal (1998) quando levantam fortes argumentos sobre as primeiras ocorrências da domesticação da mandioca, que estariam situadas em algum ponto entre Rondônia e Mato Grosso, e mais, vinculam as terras pretas antigas encontradas em Miller et. al. (1992) fatores que podem atestar tal hipótese. 


\section{CAPITULO 4}

\section{NA DIREÇÃO DAS PERIFERIAS EXTREMAS DA AMAZÔNIA}

(...) Quando eu canto uma milonga eu ergo uns metros de altura, nem minuano segura, alma, garra e violão(...)

Noel Guarany

A caracterização como área periférica da floresta Amazônica para o Estado de Rondônia, é encontrada em Ab'saber (2000), e é dada devido à diversidade que caracteriza o Estado, tanto do ponto de vista geológico como em relação aos biomas encontrados. Esta riqueza de situações, aliás, como já mencionamos, é lembrado por Miller (1999) quando sugere que o panorama ecológico diferenciado encontrado pode trazer ricas informações para elaboração de hipóteses sobre a dinâmica populacional da Amazônia.

A diversidade do registro arqueológico encontrado em Rondônia, sua amplitude temporal - atestada em mais de 9000 anos de história - podem ser resultado dos diferentes modos, diferentes povos, que modificaram a paisagem ao longo do tempo. Duas publicações em especial, Miller (1999) e Miller e Meggers (2003) são as últimas interpretações sobre a área e em ambas, a instabilidade/limitação ambiental e sua relação com o registro arqueológico são pontos de partida para as explicações.

Este trabalho teve como objetivo além de reunir em um só volume grande parte dos dados arqueológicos disponíveis atualmente para o Estado, mas também realizar uma discussão inicial sobre alguns temas que se tornam pertinente, na medida em que são pontos basilares na interpretação dos modelos mencionados já estabelecidos, e uma reavaliação na luz de informações que temos somente agora nos levou a questionar, ou melhor, a discutir, a interpretação atual da área em questão.

Um exemplo é como abordamos a Terra Preta Arqueológica. Como vimos no capitulo dois, a relação entre a seriação cerâmica e as diferentes colorações da 
terra escura leva os pesquisadores (Miller 1999, Meggers e Miller, 2003) a crer que o registro arqueológico pesquisado é resultado de sucessivas ocupações em determinados locais preferenciais (como em RO-JP-01: Cachoeira do Teotônio). Como destacamos, foi à seriação cerâmica e não a descontinuidade estratigráfica do material, que determinaram a hipótese.

Outra questão, que não vai de certa forma, contra as posições defendidas por alguns arqueólogos, está relacionada à antiguidade do sitio lito-cerâmico Encontro. Se por um lado atualmente os dados arqueológicos não suprem uma carência de dados ainda necessário para a localização da origem das primeiras expansões dos grupos relacionados à tradição arqueológica Tupiguarani, por outro, a relação entre os dados arqueológicos e a lingüística já não é novidade na arqueologia, e foi a partir da relação destes que as principais hipóteses e discussões estão pautadas (Lathrap, 1970, Brochado, 1984, Noelli, 1992, 1996, entre outros.) Aliás, sendo as evidências arqueológicas ainda não tão refinadas, como as reconstituições das origens e dispersões dos Tupi baseadas em evidências lingüísticas e etnológicas, pretende-se utilizar, livremente, com caráter especulativo, modelos já estabelecidos, a fim de realizar uma verificação em relação aos dados arqueológicos que expomos nos capítulos anteriores.

É interessante como recentes dados publicados em diferentes áreas colocam a região do sudoeste amazônico como centro na formação de hipóteses. Se a primeira vista, arqueologicamente, a datação do sítio arqueológico Encontro, que está atestada entre 4200 e $4400 \mathrm{AP}^{51}$, pode parecer um pouco recuada dada as características do assentamento e sua cultura material, entretanto a lingüística poderia assimilar a datação mais facilmente, pois existem autores que trabalham com a idéia de que a origem das primeiras expansões dos povos pertencentes ao tronco lingüístico Tupi ocorreria em Rondônia, entre 4000 e 5000 anos AP.(Rodrigues, 1964, Migliazza, 1982).

A datação também não seria estranha em relação à principal hipótese acerca os locais das primeiras domesticações da mandioca, determinadas pela biologia genética, em Olsen e Schaal (1998). Além de colocarem uma área de

\footnotetext{
${ }^{51}$ Os detalhes sobre as datações radiocarbonicos podem ser conferidas nas paginas 8-0
} 
origem entre os estados de Mato Grosso e Rondônia, citam a TPA encontrada por Miller et al.(1992) como informação que auxilia na sustentação de sua hipótese.

É a partir do estabelecimento da cerâmica e das TPA's em alguns pontos do Estado, não em todos, é que nota-se certa uniformização dos vestígios arqueológicos, talvez ligado ao sucesso na adaptação dos grupos tanta na terra firme, como nas áreas adjacentes a várzeas.

Durante a elaboração do trabalho nos preocupamos em utilizar dados atuais, recentemente publicados, tentando colocá-los na problemática arqueológica, como no caso da biologia genética, dos isótopos estáveis do Carbono e dos dados sobre a TPA. Outro aspecto levado em consideração é que recentemente vem-se utilizando a calibragem das datações radiocarbônicas de acordo com novas curvas. (mais detalhes em Kneip, 1996, Rogge, 2003 e Araujo, 1996) Uma das premissas levadas em consideração na criação do método de datação de objetos de origem orgânica por radiocarbono seria que a produção da taxa de carbono na natureza é constante. Atualmente sabe-se que esta informação não procede, e que os anos medidos pelo radiocarbono não são equivalentes aos anos do calendário. Com a colaboração de diversos laboratórios do mundo inteiro e muitos anos de dedicação vem-se produzindo curvas de calibragem cada vez mais apuradas. Os anos radiocarbonicos transformados em anos do calendário, são obtidos a partir de curvas, resultado normalmente de um conjunto de dados comparados, como no caso da última atualização, procedentes da dendrocronologia, datação por urânio de corais e a cronologia de valvas terrestres que aprimoraram dados especialmente para os últimos 24000 anos, na curva conhecida por INTERCAL04.14c (Reimer, et al. 2004)

Para a distribuição cronológica dos traços selecionados na interpretação fez-se então necessária a calibragem dos resultados das datações radiocarbônicas publicadas por Miller ${ }^{52}$ a fim de atualizar estas informações, acurando os dados da cronologia regional, e verificando em que contexto arqueológico se enquadra a cronologia atribuída ao sítio Encontro.

${ }^{52}$ Miller et al.(1992) Miller (1992,1999) 
Atualmente existem aplicativos desenvolvidos por laboratório de vários países que se propõem em realizar a conversão da idade radiocarbônica em anos do calendário. Escolhemos o programa Calib 5.1b (Reimer, et al. 2004) pois este contempla as últimas atualizações em relação às curvas de calibragem (INTERCAL04.14c) e sua interface proporcionou a criação de gráficos e dados sobre a probabilidade das datações que estão reunidos no anexo 4 .

Sendo assim, os dados cronológicos atribuídos aqui às fases, sítios e subtradições arqueológicas já conhecidas, e contempladas no capitulo dois desta dissertação, sofrerão uma mudança, tornando-se em vários casos diferentes dos já publicados por Miller.

\section{Cerâmica}

Nos principais modelos de explicação do desenvolvimento cultural do passado amazônico (Lathrap, 1970, Meggers, 1971, Brochado, 1984) o Estado de Rondônia é colocado como parte importante no processo de expansão das populações. È destacado por Brochado (1984) como área das primeiras divisões Tupi, que dariam origem ao Tupiguarani. Apesar de não haver uma concordância cronológica com os dados atuais, a proposta do autor coloca em evidencia a importância das pesquisas arqueológicas no Estado.

Os primeiros indícios cerâmicos ocorridos no Estado, atribuídos à fase Bacabal (Miller, 1992 e 1999), podem estar ligados a um evento que começa a ser recorrente na história da Amazônia, de que as manifestações cerâmicas iniciais estão relacionadas a grupos especializados na obtenção de recursos aquáticos, em sambaquis, tanto nos rios, quanto nas várzeas (no baixo Amazonas, sítio Taperinha, Roosevelt et. al. 1991, sambaquis no baixo Xingu Perota, 1992) como na costa atlântica (Sambaquis da tradição Mina, Simões, 1981). Por este motivo, ocupação destas sociedades pode ser considerada economicamente distinta em relação ao que é demonstrado nos sítios sucessivos na cronologia conhecida em cada local. Como é o caso da fase Bacabal $\left(4335 \pm 240\right.$ e $\left.3885 \pm 270^{53}\right)$ em Rondônia. Situada nas planícies aluviais do Pantanal do Guaporé, em sambaquis da Tradição Sinimbu, sua cultura

${ }^{53}$ Datação calibrada (2 sigma) a partir de Miller (1999) 
material cerâmica ser considerada singular em relação às fases subseqüentes, não tendo nenhum traço característico em comum com as cerâmicas que ocorrem sucessivamente na cronologia arqueológica conhecida no Estado.

Num horizonte cronológico semelhante, mas em uma situação topográfica e de contexto arqueológico totalmente diferente estão os vestígios cerâmicos resultado das pesquisas do sitio Encontro. Este sítio lito-cerâmico torna-se até o momento ao mesmo tempo a ocupação lito-cerâmica com a presença de cerâmica policroma, e a evidência de TPA associada à cerâmica mais antiga em toda a Amazônia. Dado também o fato que este seria um horizonte cronológico ligado ao holoceno médio (5000-3000 anos AP), período com poucos dados arqueológicos não só em Rondônia, mas em todo do território amazônico. Achamos isto importante pois neste recorte temporal podemos encontrar indícios que possam explicar com mais clareza processos, como 0 da popularidade de ocupação lito-cerâmicas, em muitos casos embasadas na TPA a partir de 2900 anos AP (no caso de Rondônia)

Os vestígios cerâmicos do sítio Encontro estão situados em uma área marcada pela diversidade de ocupação atestada pela variedade de fases cerâmicas em sua maioria associadas à Tradição Tupiguarani (cf. Miller 1987a,b). Infelizmente, devido a carência de aspectos comparáveis, como a morfologia dos potes, por exemplo, não foi possível vincular da cerâmica do sitio a alguma fase estabelecida. Mas é interessante perceber que além do antiplástico ser similar as fases Taiassú, Macunã, Guaximim, Pindaíba ${ }^{54}$, os tipos cerâmicos decorados mais populares do sitio Encontro (corrugado, roletado, inciso e ungulado) estão presentes na maioria das fases determinadas por Miller ${ }^{55}$.

A pintura, diferentemente do tratamento plástico dado a superfície, teve menor variação e recorrência na região. A pintura branca e preta, e o engobo vermelho são encontradas somente nas fases Urupá e Inimbó. Apesar de

\footnotetext{
${ }^{54}$ Predominantemente mineral (areia), com uma variação na ocorrência de mica. O cariapé aparece em uma pequena porção dos tipos da fase Urupá e são raríssimos na Inimbó

${ }^{55}$ Corrugado, roletado, inciso são encontrados nas fases Macunã, Guaximim, Pindaíba e Urupá, inciso roletado, somente em Macunã e Pindaíba,(Miller, 1987, 1987)
} 
pouco significativa, a amostra de cacos pintados do sítio Encontro apresentou maior variedade ao que é atestado na região.

A localização do sítio, suas dimensões e espessura da camada arqueológica são semelhantes ao padrão de assentamento identificado nas fases de Miller (1987jipa). Os sítios cerâmicos, de uma maneira geral, estão situados em terrenos elevados, normalmente não próximo aos cursos d'água, mas sim a centenas de metros mata adentro. Esta posição nos interflúvios, acima das cheias, e uma distância semelhante em relação ao curso d'água são características recorrentes na maioria dos sítios desta região. Em relação às dimensões dos assentamentos, as medidas que temos do Encontro ficariam entre os menores assentamentos das fases de Miller no rio Jiparana:

(...)As áreas demarcadas por evidências arqueológicas são elipsoidais, com eixo maior paralelo ao curso d'água mais próximo, com dimensões entre 14130m2 e 79128m2(...)(Miller, 1987 p.81)

Além das fases tupiguarani a área é demarcada pela diversidade de sítios pertencentes a outras filiações culturais, não definidas, mas caracterizadas como não Tupi, por Miller (1987) Apesar de não possuir informações sobre a cronologia arqueológica para a área, Miller sugere sua antiguidade, e que as diferentes fases cerâmicas seriam resultado da alta diversidade lingüística marcada na área, e, que a elevada quantidade de sítios-habitação também seria resultado deste processo.

(...)paralelamente a elevada quantidade de fases culturais, outro fato arqueológico que chama a atenção: é a quantidade de sítios-habitação de superfície $(0-60 \mathrm{~cm})$, cronologicamente situados nos últimos 2500 anos AP. Áreas tanto dentro da UHE de Ji-Paraná, como fora, com concentração grande sítios permitindo uma média de 1 sítio/ km2(...)(idem, p. 82)

O pesquisador se apóia nas informações defendidas por Rodrigues (1964), um dos modelos lingüísticos mais citados entre os arqueólogos(Lathrap, 1970, Meggers e Evans 1983, Miller, 1983, 1987,1987, Schmitz, 1991). Neste trabalha basilar de 1964, Rodrigues propõe que a diversidade de famílias do tronco Tupi próximas (a maior entre os Tupi) numa área entre o rio Guaporé e 
Aripuanã, seria resultado da longa duração da língua no local, ou seja, provavelmente o centro de expansão da língua Tupi estaria ali.

Outra informação importante, que complementa o discurso acima, é o modelo desenvolvido por Migliazza (1982), também amplamente difundido entre as hipóteses que discutem a origem do Tupi arqueológico.

(...)A glotocronologia de Migliazza (1982) para as proto-famílias do tronco Tupi, sua diversificação e migrações a partir aproximadamente de 4000 anos $A P$, correlaciona-se com os dados arqueológicos, dando ênfase para a diversidade das fases, ao menos para as famílias do tronco Tupi, justificando o elevado número de sítios-habitação arqueológicos encontrados.(...)(Miller 1987, 82-83)

Já em 1983, na sua dissertação de mestrado, Miller discute a união dos dados arqueológicos, etnohistóricos, lingüísticos e paleoambientais. Indica dois possíveis pontos de origem de expansão dos falantes Tupi, dado a convergência de elementos em comum, sendo localizado em Rondônia e/ou dividindo o espaço com Mato Grosso.

(...)Restringi-se, nesse sentido, cada vez mais a área da terra natal original, ao ponto de enquadrá-la (1) entre os rios AltoMadeira e Guaporé a oeste e Ji-Paraná a leste (Nimuendajú 1948:mapa 3; BRASIL IBGE, 1981b: 52 e mapa; Rodrigues, 1945: 333-336, 1964:97-104; Horn e Riester em Riester 1977, 49-51.), ou (2) entre os rios Ji-Paraná a oeste e Aripuanã a leste, datando-a, numa ou noutra área, entre 5000 e 4500 a.P. Nos seqüentes 2000 anos as oito famílias conhecidas se originaram de uma primeira e pequena expansão, entre os rios Alto-Madeira e Guaporé a oeste e o Xingu a Leste (Fig.15) (Rodrigues, 1945 e 1964:103-104). (...) Miller (1983) p.90 grifo nosso

Entre os dados convergentes que dão suporte aos argumentos defendidos por Miller, é observado que a localização destes territórios estaria inserida nos denominados Refúgios do pleistoceno:

(...) A área entre os rios Ji-Paraná e Aripuanã coincide com uma área de refúgio florestal, o refúgio Aripuanã-Rondônia (Fig 15-16); a área entre os rios Alto-Madeira e Guaporé a oeste e o Ji-Paraná a leste, em sua porção SE, com o Refúgio 
Guaporé, desde o pleistoceno final. (Riester 197750 - 51, Migliazza, 1982). (...) (idem)

Estes modelos permanecem sendo avaliados, como em Schmitz (1991). O pesquisador aponta a origem da tradição Tupiguarani na porção sudoeste do território amazônico, baseado nos modelos supracitados. A localização mais precisa seria entre os rios Jiparaná e Aripuanã, há 5000 anos AP. Lembra que Migliazza (1982) afirma que entre 5000-3000 anos AP tem-se uma expansão, e pontos como o alto Madeira e o Guaporé são alcançados e diversificando a língua proto-Tupi que daria origem as famílias conhecidas hoje em dia. Ainda cabe citar a importância dada a este período pelo autor quando atribui o momento as origens da cerâmica e agricultura: "Nesse tempo devem ter chegado até eles os primeiros cultivos e provavelmente os conhecimentos da fabricação de cerâmica”.(Schmitz, 1991, p.35 )

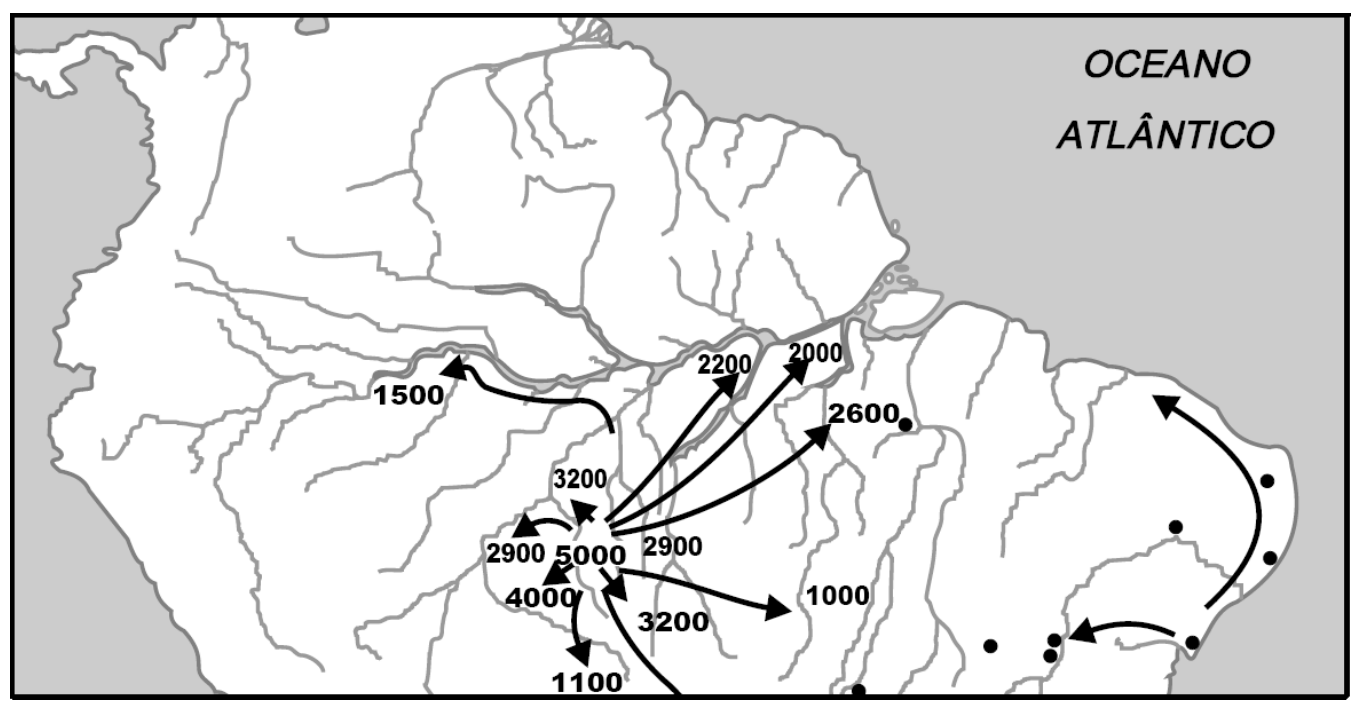

Imagem 55: reprodução parcial do mapa de Schmitz (1991, p.56) indicando a diversificação das línguas do tronco Tupi, em anos AP, de acordo com Migliazza(1982).

A ligação entre o tronco lingüístico Tupi e sua cultura material denominada Tradição Tupiguarani é proposta em diversas pesquisas e cremos que a relação entre um grupo lingüístico e determinados traços tecnológico cerâmicos não é uma tarefa fácil de estabelecer. Mas ao mesmo tempo, não é de hoje que o corrugado, por exemplo, é relacionado à cerâmica pertencente aos Tupiguarani e a ocorrência deste tipo de cerâmica é ligada aos movimentos 
migratórios dos povos falantes tupi-guaranis (Meyers, 1998). As hipóteses de distribuição do tipo correspondem com as evidências lingüísticas, históricas dos Tupi-guarani do século XVI (Lathrap et al., 1987, Meggers e Evans, 1983, Myers, 1988).

Apesar de não muito bem documentada, a afinidade entre a cerâmica da Tradição Tupiguarani e o tronco lingüístico é aceita, e atualmente podemos elencar uma série de pesquisas que aceitam as hipóteses trabalhadas pela lingüística, estreitando assim sua relação com a arqueologia. (Lathrap, Meggers, Meggers e Evans, Miller 1983, 1987, 1987, Brochado 1969, 1977, 1980, 1984, Noelli, 1996 entre outros).

Como mencionamos, entendemos o termo Tupiguarani como uma referência à grande tradição arqueológica espalhada pelo continente sul-americano. A definição do termo foi explicada por Brochado (1973, p.9):

(...)La alfarería de la tradición Tupiguarani, en el momento de los primeros contactos con los europeos, fue encontrada exclusivamente entre grupos indígenas de la familia lingüística Tupi-guaraní, a pesar de que de ninguna manera todos los que hablaban Tupi o Guaraní poseían cerámica. (...)

De maneira geral são sítios superficiais com cerâmica apresentando pintura policroma (vermelho e ou preto sobre engobo branco ou vermelho), e técnicas plásticas de acabamento preponderando o alisado, o corrugado, o ungulado, escovado, além de superfícies apenas engobadas. (Chmyz, 1976; PRONAPA, 1969; Brochado, 1981).

A cerâmica corrugada, com relação aceita com a tradição Tupiguarani, também aparece entre as tradições Taquara e Una, na costa sul do Brasil, há quase dois milênios (Meggers e Evans,1983). De acordo com a cronologia atual, o estilo se difundiu junto com expansão guarani, provavelmente desde 0 Amazonas central subindo o Madeira ou o Guaporé, e descendo depois o rio Paraguai, entre 2000 -1500 AP. Aparece também no médio rio Ucayali, aproximadamente por volta de 1300 AP. (Brochado, 1984, Lathrap et al., 1987, Myers, 1988). O corrugado também aparece em grande parte do Equador oriental, incluído os rios Napo e Upano. No complexo Valdívia, existe a 
ocorrência, mas esta pode ser culturalmente e temporalmente distinta das demais $^{56} \cdot$ (Guffroy, 2006)

Sabe-se que pelo menos quatro famílias lingüísticas históricas diferentes parecem estar relacionadas com o estilo: ao norte Arawak, ao Oeste Jíbaroan e Pano e ao Sul Tupi-Guarani. Os complexos cerâmicos citados têm em cada região características únicas que provavelmente pode ter sido reflexo de situações particulares e a processos de aquisição da técnica particulares. Obviamente a distribuição da cerâmica corrugada em setores dispersos de uma mesma área não pode ser explicada de uma maneira simples, como o deslocamento de um só grupo e tampouco pelo mecanismo de difusão (idem)

A ocorrência desta cerâmica corrugada, tão antiga (4300 anos AP) no sudoeste da Amazônia (Sítio Encontro), além de outras características Tupiguarani que a cultura material possa ter, apesar da necessidade de um debate para o melhor estabelecimento desta tradição principalmente a nível regional, pode auxiliar na problemática da origem expansão dos grupos Tupi.

Os modelos debatidos até então, são alternativos em relação ao de Lathrap (1970), que foi seguido por Brochado (1984), e atualmente é considerado o modelo arqueológico mais completo. A analogia entre etnohistória, lingüística e arqueologia fez com que Brochado (1984) considerasse a expansão dos Tupi a partir da Amazônia central, no médio curso do Amazonas, subindo o rio Madeira os povos que dariam origem aos Tupiguarani, descendo o Amazonas e deslocando-se pelo Nordeste até atingir o litoral do Sudeste, os grupos que deram origem ao Tupinambá.

Lathrap (1970) e Brochado e Lathrap (1980) argumentam que a maior parte da expansão geográfica da Tradição Policromica da Amazônia, com exceção dos Llanos Venezuelanos, estão correlacionados com a expansão dos Tupis desde a Amazônia central.

Brochado (1984), p.305:

(...) Entre 5000 e 4000 AP Araucanos e Tupis começam a se espalhar rio acima desde a Amazônia central, entre a boca do

${ }^{56}$ Datações em sítio com cerâmica Valdívia da costa do Peru, recuam a 5000 AP. 
rio Negro e a boca do rio Madeira, colonizando inclusive os afluentes deste rios. Estes Tupis antigos também se espalhariam rio abaixo ao longo das várzeas amazônicas.(...)

Também influenciado por Rodrigues (1964), Brochado avaliava que as divisões que afetaram a língua ao longo do tempo colaboraram para a variabilidade dos vestígios cerâmicos, e sendo assim, como citamos, teriam surgidos as diferenças entre a cultura material dos Tupiguarani a oeste e sul, e os Tupinambá ao leste.

Considerando somente a expansão dos povos que dariam origem aos Tupiguarani, Brochado (1984 p. 330) argumenta que:

(...)Desde a porção oeste da Amazônia central ao para a bacia do Paraguay-Paraná, a única rota é, como mencionei, subindo - Madeira-Guaporé(lténez) porque é o único lugar onde as áreas de várzea de ambos os rios estão conectadas sem a intervenção de terras altas(chapadão).(... $)^{57}$

O termo expansão não é propriamente o termo usado pelos pesquisadores, que trazem o conceito difusionista de migração para o espraio da cerâmica Tupi pelo continente. Aliás, esta é uma das criticas pertinentes ao modelo. (Noelli, 1996 e Heckenberger et al.1998)

A tradição Tupiguarani é a única tradição com pintura policrômica (no Brasil) localizada fora da Amazônia, um dos motivos pelos quais foi levantada a hipótese (Brochado 1984). Ao mesmo tempo, Heckenberger et al. (1998) realizam uma crítica em relação aos dados arqueológicos utilizados por Brochado referentes à tradição Tupiguarani, por serem procedentes de fora do território amazônico, além disso, argumentam que o pesquisador realiza uma associação direta entre a Tradição Policroma da Amazônia e os grupos Tupi, embora tal evento não ter sido realmente avaliado

57 (...)From the western section of Central Amazonia to the Paraguay-Paraná watershed, the only route is, as I have already mentioned, up the Madeira-Guaporé (Iténez), because it is the only place where the várzea areas of both river systems are actually interconnected without intervening uplands (chapadão)(...) 
Pesquisas atuais na Amazônia Central colocam uma questão interessante, apontando que a tradição policroma amazônica nesta região não é tão tardia quanto consideram os modelos interpretativos, além de não corresponder como ocupação mais antiga documentada desta tradição na bacia amazônica. Lá a ocupação desta filiação inicia-se por volta de 1100 anos AP e os vestígios mais antigos de 2300 AP são relacionados a fase Açutuba, (Heckenberger et ali, 75:1998, Lima, 2006)

No Estado Rondônia a Tradição Policroma amazônica tem seus primeiros indícios documentados por volta de 2900 anos AP, associado à terra preta arqueológica nos grandes sítios da subtradição Jatuarana. Persiste durante quase 2500, sem muitos hiatos, na região do médio Madeira e seu afluente da margem direta, o rio Jamari, representado por fases da Tradição Jamari.

Deste modo, a partir de 2900 anos AP temos uma série de evidências

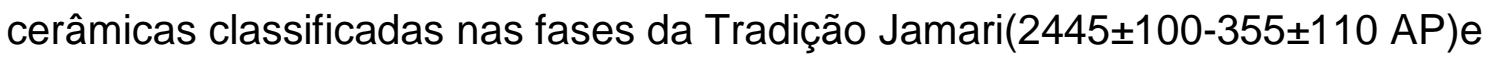
na subtradição Jatuarana(2870 $\pm 135-2385 \pm 230$ AP) relacionadas à Tradição Policroma da Amazônia. A fase Urucuri, a mais antiga da tradição Jamari foi considerada como muito próxima da fase guarita, apesar dos poucos atributos comparáveis, por Miller (1999) Esta fase é diferenciada por Miller (idem) como uma cerâmica simples, com poucos fragmentos com antiplástico de cariapé, predominando a areia. São encontrados junto a borda e lábio, motivos e técnicas de decoração plástica e policroma definidos como da Subtradição Jatuarana. Sendo a mais antiga da Tradição, data de 2500 AP. Nas demais fases sucessivas da tradição, o cauxí e o cariapé vão sendo gradualmente sendo acrescidos na pasta cerâmica. A seqüência cronológica elaborada por Miller et al. (1992) é uma das mais refinadas para a Amazônia, atestando, a partir de 44 datações por radiocarbono, uma ocupação de mais de 2000 anos para a filiação cultural

Esta série de dados que temos para a região Sudoeste da Amazônia, a presença deste tupi de forma ampla, próximo as bordas da floresta e o cerrado e indícios de ocupação bem antiga coincidindo com as informações lingüísticas, inserem a região como importante ponto de discussão para o levantamento de informações sobre as antigas expansões Tupi. 
Parece que até o momento, algumas proposições levantadas pelos modelos alternativos a Lathrap (1970) e Brochado (1984) podem estar se confirmando. Mesmo assim, este modelo (o de Brochado) baseado em dados arqueológicos e lingüísticos, continua sendo amplamente aceito pela arqueologia com relacao a expansão dos ceramistas da tradição Tupiguarani, mesmo com criticas. Como a de Scatamacchia (1990), que apesar de não tirar da Amazônia o local de origem dos Tupi, considera que as datações mais antigas na época para a policromia cerâmica estariam inseridas em contextos não amazônicos. A idéia da autora aponta para que as migrações Tupi poderiam ser ainda mais antigas do que se pensa. Neste mesmo caminho estão os resultados e interpretações de Schell-Ybert et. al. (2800) ao discutirem datacoes radiocarbonicas para sitios Tupi no sudoeste brasileiro (RJ) com aproximadamente 3000 anos. Se observamos, os dados das datações do sitio Encontro, e os demais exemplos de cerâmica policroma antiga em outros pontos do sudoeste amazônico apontam também para que as primeiras expansões Tupi tenha saído de algum ponto da Amazônia, mais especificamente, da borda sudoeste.

Entre as duas regiões mais citadas, o alto Madeira/Jamari, e o alto/médio Jiparaná temos distinções, do modo que a primeira tem cronologia um pouco mais recente, por volta de 2900 AP. A cerâmica do o alto Madeira/Jamari associada à Tradição Policroma, tem como características principais o engobo vermelho e o roletado, além do fato do padrão de assentamento estar ligado a sítios com TPA, o que não ocorre aparentemente com tanta freqüência no Jiparaná, onde a cerâmica Tupiguarani começa a ocorrer por volta de 4300 anos atrás. O fato que pode ser um elo entre os dois momentos e locais distintos é o caso de que ambos os assentamento podem ser resultado da ocupação em aldeias tanto na terra firme, quanto adjacente à várzea, que obtiveram sucesso em algum tipo de sistema econômico capaz de sustentar as populações por séculos. Mesmo de forma preliminar, pois ainda vamos aprofundar esta questão no próximo item, se trabalharmos com uma conjetura baseada em indicativos indiretos ${ }^{58}$, cabe colocar que algum momento desencadeou-se 0 espraio e o estabelecimento destes sítios, mas os motivos não conhecidos.

\footnotetext{
${ }^{58}$ (como a abundancia de ocorrências de machados polidos entre os sítios, os indicativos da biologia genética da mandioca)
} 
Para Brochado (1973) a mandioca, amplamente encontrada em todo o país, teve tal dispersão devido à adoção por grupos Tupiguarani, e estes espalharam a presença do cultivar em diferentes pontos (Brochado, 1973).

Avaliamos que ainda é necessário trabalhar muito para de entendermos de uma maneira mais clara a vasta variabilidade que comporta o Tupiguarani arqueológico. Nas classificações realizadas, principalmente na região do rio Madeira, fica evidente a semelhança que os conjuntos cerâmicos das diversas filiações culturais possuem. A ponto de Miller, em diferentes publicações interpretar a fase Urucuri como ora na tradição Jamari (Miller 1999) ora na subtradição Jatuarana. Também é interessante ressaltar que tal fase também teve associação com a fase Guarita em Miller (1987).

Mais dados cronológicos e da classificação cerâmica, mais testes para refinar a presença destas fases no rio Madeira ainda são necessárias para quem sabe em breve termos uma melhor compreensão da dinâmica populacional da área. A arqueologia em Rondônia pode ser considerada privilegiada, dada a visibilidade arqueológica e os poucos hiatos que compreendem uma produção cerâmica que perdurou durante 4000 anos.

\section{Terra Preta Arqueológica}

A Terra Preta Arqueológica (TPA) pode ser identificada pelas qualidades distintas desses solos em relação ao seu entorno. Sua origem é atribuída a atividades humanas cotidianas, que geraram alterações no solo local, aumentando a fertilidade química, resultante da prolongada ocupação humana. Geralmente estes solos associados a fragmentos cerâmicos e líticos, restos de fauna e flora. Em função da coloração escura da camada superficial, tais solos são conhecidos por terra preta, terra preta de índio, terra preta antropogênica e terra preta arqueológica (Kern e Kämpf, 2003).

Designa a camada de ocupação humana em um sítio arqueológico, afetada por atividade antrópica, geralmente correspondendo ao horizonte A do solo (Kern, 1988). Destacam-se também como indicadores dessas formações, a acumulação de Ca, P e C orgânico (Kern e Kämpf, 1989). Segundo indica, as 
TPA's são características por apresentar este horizonte A mais escuro (cor preta a bruno acinzentado muito escuro - 5YR 2,5/1; 7,5YR 2/0 a 3/1; 10YR 2/0 a 3/2 segundo Munsell) e mais espesso do que nos solos vizinhos. São solos normalmente bem drenados, profundos, com textura que varia de arenosa a muito argilosa. (cf. Kern \& Kämpf, 1989; Kern, 1996; Kern et. al. 2003)

São encontradas em uma classe variada de solos, como Latossolos, Argissolos, Neossolos Quartzarênicos, Espodossolos. Na maioria dos casos ocorrem em Latossolos e Argissolos, estes predominantes no território amazônico, e conhecidos pela sua baixa fertilidade. Para Kämpf e Kern (2003) e Kern et al (2003) esse fato sugere que o tipo de solo pode não ter sido um fator determinante para o estabelecimento de assentamentos de grupos préhistóricos

Os sítios arqueológicos com TPA estão localizados geralmente próximos a cursos de água. Ocupam várzeas, elevações adjacentes e a terra firme interior, em extensões de menos de um hectare, característicos da terra firme, até centenas de hectares, ao longo dos principais rios e interflúvios. A ocorrência de TPA's é vasta na Amazônia, ultrapassando os limites do Brasil chegando à Colômbia, Equador, Peru e Venezuela. (Kern e Kämpf, 2003).

Dentro da Amazônia brasileira, as TPA's estão presentes em praticamente todos os ecossistemas e tipos de paisagens. A grande maioria dos sítios arqueológicos está situada em rios de águas claras, como o Amazonas, Madeira, Purus e Uamatã no estado do Amazonas, Em Rondônia: no rio Madeira, Guaporé, Jamari e Jiparaná. No Tocantins, e no estado do Pará - no Trombetas, Mapuera e Tapajós. Em rios de águas escuras como o Rio Negro no Amazonas e no rio Caxiuamã no Pará. Também ocorrem em proporções menores nos interflúvios de rios tributários do rio Amazonas, e em igarapés. Ocorrem também no alto Xingu. (Kern et. al. 2003)

Em Kämpf e Kern (2003) consideram que as características morfológicas, físicas e químicas das TPA's variam dentro de cada sítio e entre sítios, dependendo do padrão de assentamento das comunidades que a produziu. Essa diversidade é evidenciada pela amplitude dos teores de fósforo, cálcio e C orgânico nos horizontes $A$. 
O tamanho dos sítios de TPA pode variar desde menor que um hectare até maior que 400 hectares, como é o caso de um sítio em Santarém (Smith, 1980, Roosevelt 2000). Nas áreas de várzea, em terraços paralelos aos rios é que ocorrem estes sítios mais extensos. Denevan (2001) registra vários sítios em ambiente de terra firme, menores que os sítios que ocorrem terraços - de 0,3 a 0,5 hectares. Estes assentamentos também são característicos pela menor espessura da camada arqueológica, podendo representar uma (ou mais) casas comunais, ou anel de casas menores. Contudo, grandes sítios com TPA foram descritos no Alto Xingu por Heckenberger (1998). Estes sítios possuem extensões de 30 a 50 hectares e estão localizados na terra firme.

Para Petersen, et al. (2001), o estabelecimento da agricultura como maior fonte de produção de alimento na Amazônia proporcionaria as condições básicas para a formação da Terra Preta Arqueológica. Resultado de pesquisas na Amazônia Central os autores argumentam que tendo um processo de agricultura estabelecido, verifica-se a emergência de padrões residenciais e econômicos que continuariam lá por séculos, até o inicio da colonização Européia, com um elemento em comum, a TPA.

Com essa argumentação inicial, temos uma idéia da discussão e da caracterização, mas acima de tudo, da importância dos estudos sobre a Terra preta arqueológica para arqueologia amazônica. A demanda de estudo sobre este tema é recente, mas ao mesmo tempo estão aprofundadas algumas discussões já publicadas. Pensado em acessar novamente os dados já disponíveis a luz desta nova carga de informação é que avaliamos as Terras Pretas em Rondônia, já iniciada no capitulo 2. Reportamos que sítios contendo TPA foram localizados em diferentes locais do Estado. Ao norte no rio madeira, a oeste no rio Guaporé, e a leste nos rios Jamari e Jiparaná, ocorrendo tanto em ambiente de várzea (rios Madeira e Guaporé), em planície de inundação(Jamari e Jiparaná) e em terra firme (rio Jamari e Jiparaná).

Concordamos que TPA's podem ser consideradas reflexo de atividades humanas em um determinado local. Para Smith (1980), sua coloração escura e sua a espessura podem ser relacionados com a duração da ocupação do sítio e, ou, a densidade da população. Ao contrário de Miller et a.i (1992) e Miller 
(1992) observa na alternância de camadas de solo de terra preta, ora mais escuras, ora mais claras, um reflexo de alterações climáticas, e logo, de populações. Miller (1992, p. 221):

(...) camadas de terra preta mais escura devem refletir períodos de maior umidade, permitindo reocupações mais intensivas e freqüentes, enquanto as camadas mais claras devem evidenciar menos umidade, com menor índice demográfico ou ocupação menos prolongada (...)

No entanto entendemos que as propriedades físicas e morfológicas, dentro dos sítios com TPA não são uniformes, e segundo Kern (1988 e 1996), suas variações são explicadas por diferentes atividades, e não necessariamente mudanças climáticas. Concordamos também com Kämpf et al. (2003) e Kämpf e Kern (2003) quando fazem referência que atualmente está confirmado que a Terra Preta se forma a partir de atividades humanas relacionadas à assentamentos e práticas agrícolas de indígenas pré-colombianos (Smith, 1980, Eden et al., 1984, Pabst, 1985, Andrade, 1986, Mora et al., 1991, Kern, 1988 e 1996).

No rio Madeira, entre a subtradição Jatuarana, a constante reocupação atribuída aos assentamentos é caracterizada por:

(...)O concentrador desta composição(TPA) é a maior permanência e sobretudo as reocupações dos sítioshabitação(...)(Miller 1992, p. 220)

(...) Principalmente entre as cachoeiras Teotônio e Santo Antônio, a concentração de grandes, espessas e densas camadas de terras pretas antropogênicas, com cerâmica contínua horizontal e verticalmente, é compatível com uma intensa e constante reocupação de sítios- habitação. (...) Miller (1999, p.337)

Contudo, a interpretação destas camadas como constante reocupação dos sítios é dada somente quando são ligados aos dados da seriação dos tipos cerâmicos, e só se fundamentariam a partir desta relação. A constante reocupação nos sítios, para o pesquisador, não é atribuída a interrupções de presença de material arqueológico entre as camadas estratigráficas. Miller (1987riomadeira, p.31) comenta que nos sítios da subtradição Jatuarana na foz 
do rio Jiparaná a "cerâmica é abundante por todo estrato arqueológico, desde a superfície".

Entretanto, em sítios-habitação, entre a margem direita do alto-médio e baixomédio Madeira as margens do rio das Garças (afluente do Candeias-Jamari), a cerâmica ocorre esparsa e descontinuamente, horizontal e verticalmente, sugerido, segundo Miller (1992) reocupações sazonais por pequenos grupos Jatuarana durante as cheias.

Mas estes exemplos, quando citados, são pouco aprofundados.Um melhor entendimento destes sítios mata a dentro, na terra firme poderia ser útil para a compreensão dos grandes sítios adjacentes a várzea.

Mas, retomando sobre a composição estratigráfica das camadas de sítios da do Jamari, Meggers e Miller (2003) comentam que a seriação cerâmica é um exercício válido e as datações, que por vezes variam em muitos anos dentro do mesmo sítio só tem a confirmar estas reocupações.

(...) además de confirmar la ocupación discontinua del sitio, la magnitud de estas discrepancias llama la atención a una característica importante de la estratigrafía natural de los sitios amazónicos, que consiste en la ausencia de una acumulación de solo estéril durante periodos de abandono(...)Discrepancias entre una fecha y el contexto resultan también de la intrusión del carbón de ocupaciones posteriores en niveles anteriores. Esta situación complica las correlaciones entre los fechados e las secuencias seriadas.(...) (idem)p.341

No entanto, percebemos também que para esta região algumas diferenças marcantes são encontradas dentro de fases, onde colocam as filiações mais antigas como mais permanentes em relação às demais.

(...)Existen diferencias marcadas entre las duraciones de las fases, el total de sitios ocupados y la proporción entre sitios reocupados y sitios nuevos. La existencia de 14 sitios para las fases Jamari e Cupui, que perduraron unos 700 anos, y 22 para La fase Matapi con una duración de 300 anos, implica menor permanencia en la aldea en la fase Matapi. Mientras que solamente un sitio de La fase Jamari esta en un nuevo lugar, 9 de los sitios de La fase Matapi no nuevos(...)(idem) 
O problema de datação, assim como a interpretação sobre a ausência de hiatos de material arqueológicos entre as fases é uma avaliação que pensamos que poderia ser analisada com mais detalhes.

Nesta mesma publicação fica claro o posicionamento dos pesquisadores em relação aos grandes sítios com terra preta arqueológica na Amazônia. Creio que as interpretações sobre a dinâmica populacional podem ser pautadas a partir da assunção de que este fenômeno é ou não fruto de ocupações que tem um caráter permanente. Ou melhor, um maior entendimento dos processos que formaram estas camadas interpretadas como TPA e uma vinculação mais estreita com as fases arqueológicas seriam necessárias para que possamos melhor avaliar esta questão de constantes reocupações.Longe de questionar as classificações cerâmicas determinadas para a área, de fato existem diferenças tipológicas, e são estas informações que nos guiam no entendimento sobre a ocupação cerâmica regional, mas a respeito da interpretação da TPA, acreditamos que a discussão é pertinente deva ser iniciada. É claro que não podemos generalizar, mas como viemos insistindo, a TPA não é por si só um individuo padrão, existem diversos tipos de TPA. É interessante pensar que, na medida em que temos hoje em dia diversas pesquisas sobre esta variedade de ocorrencia de TPA, citando somente alguns autores, como Herrera et al.(1992), Heckenberger (1998), Roosevelt (1989, 2002), Mora et al. (1992), percebemos que em comum, os sítios extensos contendo TPA são interpretados como ocupações permanentes ou semipermanentes, de longa-duração, durando séculos, de populações que praticavam a agricultura.

O argumento defendido por Miller $(1992,1999)$ pode ter tido como base a argumentação do discurso de Meggers (1971, 1977, 1990, 1996 e 2001) em que, de maneira geral, a Amazônia não teria condições de sustentar ocupações duradouras, estáveis, e que grandes sítios arqueológicos são fruto de constante reocupação de locais preferenciais.

Uma das grandes sínteses interpretativas para o sudoeste é encontrada em Miller (1999). Trata-se de um ensaio abarcando o conceito de período 
Formativo $^{59}$. Ford (1969) quem estabelece o conceito básico de Período Formativo para a América. Ao reavaliar o trabalho de Willey e Phillips (1958), considera que, por tratar-se de um território muito amplo, eventos como agricultura e introdução cerâmica, por exemplo, ocorreram diferentemente no tempo no espaço. O conceito estabelecido, de uma maneira mais geral, sem levar em conta as subdivisões, é que o período Formativo seria:

(...) os três mil anos (ou menos em algumas regiões), durantes os quais os elementos cerâmicos, ferramentas líticas, figuras, agricultura de milho e mandioca foram sendo difundidos $e$ fixados na vida socioeconômica das populações (...) estas populações possuíam uma economia e tecnologia Arcaica (...) no seu final (o período formativo) possuiu os elementos essenciais para alcançar a civilização (...) (Ford 1969, p. 5) ${ }^{60}$

Avaliamos que a utilização deste conceito teve validade - nas diferentes formas onde foi empregado - dado o período histórico de seu desenvolvimento. Foi uma ferramenta muito utilizada na arqueologia americana nas décadas de 50-80. Permitiu organizar em uma forma inteligível os dados, e estimulou investigações acerca da origem cerâmica e a horticultura incipiente. O modelo elaborado por Ford (1969) é criticado por tratar um assunto tão complexo de uma maneira simples, mas, ao mesmo tempo, foi incentivo direto e indireto para a criação de outros modelos, como o do povoamento do Equador (Meggers e Evans, 1968) e a expansão dos grupos Tupi a partir da Amazônia central (Lathrap, 1970).

${ }^{59} \mathrm{O}$ conceito de Período Formativo é utilizado, mais livremente, dentro arqueologia desde a década de 40, mas foi realmente estabelecido na década de 50. (Ford, 1969) Willey and Phillips (1958, p. 144-146) definiram o Período Formativo: (...) Pela presença de agricultura de milho e/ou mandioca e pela integração socioeconômica bem sucedida desta agricultura a um modo de vida sedentário em aldeias bem estabelecidas. (...) Produção cerâmica, inscrições rupestres em onda e uma arquitetura cerimonial especializada são normalmente associadas às culturas formativas americanas (...) Em seu conceito, os autores realizam uma tripartição do período em Recente, Médio e Tardio. Estas subdivisões são referentes às transformações de sociedades, que a partir de um dado momento começam a praticar a agricultura, de forma experimental, até as que vivem estabelecidas em aldeias, com uma agricultura bem sucedida.

60 (...) the 3,000 years (or less in some regions), during which the elements of ceramics, ground stone tools, handmade figurines, and manioc and maize agriculture were being diffused and welded into the socioeconomic life(...) all these people had an Archaic economy and technology $(. .$.$) at its end they possessed the essential elements for achieving civilization. (Ford$ 1969, p. 5) 
Miller (1999) atribui que seriam necessárias ao menos três etapas para o estabelecimento do inicio deste período, ligadas basicamente ao inicio da agricultura, cerâmica e ao sedentarismo, que geraram vestígios arqueológicos em grande parte concentrados na TPA de fases do Jamari e Madeira.

(...) Arqueologicamente, a passagem da condição de simplesmente predador para predador-produtor, ou da condição de caçador-coletor para caçador-coletor agricultor incipiente, ocorre no Sudoeste Amazônico (Rio Jamari-RO)

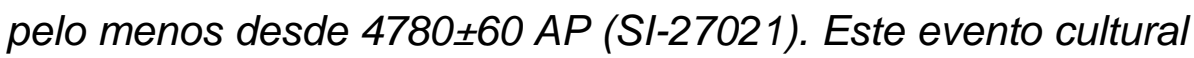
- primeira etapa do Período Formativo, com base na agricultura - está representado pela Tradição Massangana, com refugo cultural pré-cerâmica embutido em solos de terra preta antropogênica. (...) Miller (1999), p. 334, grifo nosso.

A segunda etapa é relacionada à introdução cerâmica. Miller (1999) se refere às primeiras ocupações ceramistas até então conhecidas, a Fase Bacabal e a Subtradição Jatuarana.

(...) este evento ocorreu em distintos momentos, com cerâmicas já elaboradas (produtos de difusões), que pouco se diversificaram evoluíram através do tempo, mas que se diferenciaram ao longo do espaço geográfico (...) idem, p. 335

Os dois eventos, agricultura e sua expansão e a popularização de sítios litocerâmicos ${ }^{61}$ coincidem com espraio da evidencia de TPA em diversos pontos do Estado. Mas é interessante voltarmos ao conceito formativo para melhor avaliarmos as interpretações do pesquisador.

Sendo formulado para Mesoamérica e para os Andes centrais, a elaboração teórica se perfila como uma etapa de transição entre o período de caçadorescoletores nômades e as altas culturas, com Estado, como as encontradas pelos conquistadores espanhóis. Contudo, em as áreas intermediárias como Brasil, Colômbia, Bolívia, Equador, Venezuela, digamos que não se formaram 'altas culturas', ou seja, o que deveria formar-se, não se formou. Aliás, sabemos de várias comunidades na Amazônia que não desenvolveram formas hierárquicas

\footnotetext{
${ }^{61}$ Lembramos da vasta utilização de machados polidos como demonstramos no rio Jiparaná. Notamos também a ampla ocorrência deste tipo de artefato nas supracitadas fases de Miller, além de sua associação com sítios denominados oficina-litica (polidores)
} 
sociopolíticas tão representativas como a dos cacicados. Exemplos são os grupos de caçadores-coletores Nukak, da Amazônia colombiana, (Politis, 2001), e no noroeste da Amazônia, os Maku (Silverwood-Cope, 1990). Novamente, vendo isto sob o prisma de conceito formativo, o que deveria formar-se não se formou. Em Rondonia temos o exemplo dos grupos Nambikawaras, que para Miller (1999 p.335-336) tem relação com os sítios da fase Massangana:

(...) Pela presença de vários sítios-habitação de terra preta antropogênicas sem cerâmica por tudo sub-região, é valido considerar que essa modalidade cultural de caçador-coletoragricultor pré-ceramista foi adotada ampla e extensivamente, perdurando até o presente. (...) Histórica e presentemente, ocorrem tribos nesse estágio cultural, como os Mura Pirahã e os Nambikwara. (...)

O fato da existência destes grupos que até hoje se mantém a partir da caça e coleta, como o caso mencionado acima é interpretado pelo autor:

(...) A continuidade do padrão comportamental de caçador seria resultante do complexo de condicionantes ambientais, físicos e bióticos, redundando na impossibilidade de produção de animais domésticos, compensada pela relativa abundância e facilidade de predação em ecossistemas relativamente abertos, da pesca e/ou caça e coleta. Esta situação agiu como uma barreira à transposição e superação das etapas iniciais do Período Formativo. (...) idem, p. 338

Estes mesmos fatores ambientais, físicos e bióticos também seriam condicionantes para o pleno estabelecimento dos grupos cerâmicos que ocuparam o rio Madeira e Jamari, em meio a sítios extensos com TPA, e que não estabeleceram de fato as três etapas do Formativo ${ }^{62}$

(...) Considerando-se um sedentarismo rudimentar e restrito como ou pré-requisito embrionário do sedentarismo efetivo, então parece que esse começou em algum momento da Subtradição Jatuarana, na área-tipo Teotônio, em sítios habitação junto das cachoeiras do Teotônio e Santo Antônio,

\footnotetext{
${ }^{62}$ As três etapas levantadas por Miller seriam, de uma maneira geral, correspondentes ao que outros autores remetem como inicial, médio de tardio, ou são etapas que remetem a passagem do periodo recente e tardio, a partir da bipartição do conceito achado em Meggers e Evans (1968), por exemplo.
} 
sem, contudo, ultrapassar-lo e consolidar-se. Esse evento sedentarismo rudimentar restrito - se constituiria no estágio inicial da terceira etapa do Período Formativo, última alcançada e não transposta no sudoeste da Amazônia Brasileira (...). idem, p. 339, grifo nosso.

Se de fato o período Formativo indica a maior presença de assentamentos sedentários, agrícolas, e o nascimento de sociedades com um rigor políticosocial mais complexo, como apontado em Meggers (1966), Ford (1969), Oliver ( 2001), o inicio deste período para o Estado é apontado com as primeiras evidências de agricultura, sendo uma vez popularizada por ocupações ceramistas nos rios Madeira e Jamari, por motivos ligados principalmente a restrições ambientais, não conseguiram ter sucesso e não alcançaram condições para o pleno estabelecimento do período em Rondônia (cf. Miller, 1999)

Novamente, cabe comentar que dado o momento que estamos seria muito interessante discutir melhor a relação entre as fases cerâmicas, a continuidade estratigráfica do material e o posicionamento sobre a interpretação do que é TPA e qual seriam os processos que resultaram tal ocorrência. Quem sabe também podemos começar a levar em consideração que a interpretação destas ocupações (principalmente alguns sítios subtradição Jatuarana, a tradição Jamari, e o sitio Encontro) seja resultado do estabelecimento destes grupos em assentamentos duradouros e com um sistema econômico aparentemente semelhante na região. Além disso, também pode ter ocorrido uma dinâmica entre estes assentamentos mais duradouros e outros mata a dentro, na terra firme, como em alguns caso atestados no Madeira, onde ocorrem sítios cerâmica "esparsa e descontinuamente, horizontal e verticalmente, sugerido reocupações sazonais por pequenos grupos Jatuarana durante as cheias". (Miller, 1999, p.335)

Apesar de haver uma argumentação pertinente em relação ao não desenvolvimento de algumas fases agricultoras precoces, a interpretação de uma área arqueológica, baseada no conceito de período Formativo tende em alguns casos a homogeneizar processos que podem ter uma maior complexidade aparentemente. Exemplo é o caso da relação destes sítios mata 
a dentro e os adjacentes a várzea, como no caso mencionado acima. O conceito de formativo encobriria uma gama muito variada de tipos de formação socioeconômica, representadas no registro arqueológico, desde caçadorescoletores que pescavam e realizavam experimentação da agricultura até grandes aldeias com produção de excedente. A inclusão de tantos contextos diferentes tende a igualar uma variabilidade adaptativa e cultural que pode ter sido ampla, e a minimizar a importância das conquistas de sociedades que não seguiram uma evolução unilinear. Aliás, nestes estudos, pouco sabemos de dados ligados a dinâmica dos assentamentos a nível regional, a densidade de ocupação e a dinâmica intra-sítio. Creio que podemos pensar o conceito a partir do abandono de premissas teóricas do evolucionismo unilinear, tratandoo algo fluído, adaptando-se a condições. Deve se pensar um termo que vai ser utilizado mais como uma referência cronológica, e não como um indicador evolutivo, podendo assim ter um melhor proveito das informações obtidas a respeito.

Reiteramos que os dois eventos ligados ao período Formativo, agricultura, sua expansão e a popularização de sítios lito-cerâmicos coincidem com espraio da evidencia de TPA em diversos pontos do Estado. Contudo, nem todos os assentamentos pré-coloniais geraram este tipo de solo, como podemos observar pelos poucos casos de ocorrencia na terra firme do Jiparaná. Sua gênese estaria ligada a uma mudança nos padrões de assentamentos na região, sendo assim, os solos de terra preta podem ser essenciais no entendimento da questão do comportamento populacional na Amazônia (Neves et.al. 2004).

O sítio lito-cerâmico Encontro (RO-MA-05) localiza-se na direção das áreas periféricas do sudoeste amazônico. Situado no município de Ministro Andreazza, está inserido na serrania da Providência, adjacente a porção de planície de inundação do rio Jiparaná, Rondônia. Trata-se de um assentamento pequeno, considerando os padrões amazônicos. Em sua área encontram-se duas concentrações de TPA, caracterizada a partir das assinaturas químicas do solo. Este seria o dado de sítio lito-cerâmico com Terra Preta Arqueológica, com a datação mais antiga da Amazônia, recuando a 4300 AP. Este pequeno assentamento, encravado na terra firme, na área de interflúvio entre os rios 
Jiparaná e Roosevelt, tem evidências de dois locais com a presença de TPA, aparentemente elipsoidais e não possuindo grandes dimensões (estima-se não mais de $20 \mathrm{~m} \times 15 \mathrm{~m})$. As camadas pretas que variaram entre $40-60 \mathrm{~cm}$ de espessura, dataram a ocupação do assentamento entre $4425 \pm 200$ e $4255 \pm 185$ $A P^{63}$. O fato da inserção deste sítio num ambiente de solos pobres, sua duração cronológica, corrobora com a hipótese de Kern et al (2003) de que o tipo de solo talvez não seria o fator responsável pela escolha e formação de TPA. Os artefatos líticos (três machados polidos por exemplo) podem dar continuidade ao fato da farta ocorrencia de machados polidos na região.

A idéia de que a Amazônia teria um baixo potencial agrícola, devido à predominância de solos pobres em nutrientes, possibilitando apenas cultivos itinerantes e, um desenvolvimento cultural limitado, não se encaixaria na forma como viemos discutindo os dados. Levamos em consideração os argumentos de Denevan (2001), quando discute que o potencial agrícola não é algo inerente à natureza, e independente da cultura dos seus habitantes, mas a agricultura, sendo um fenômeno cultural, implica que o potencial agrícola é em parte determinado culturalmente, envolvendo uma interação entre tecnologia e ambiente.

A ligação da agricultura e a TPA é recorrente, e para alguns autores, o desenvolvimento da agricultura daria subsídios para seu estabelecimento. Os exemplos de dois assentamentos antigos (RO-PV-48 tradição Massangana e Encontro) onde possam ter ocorrido experimentações, e os desenvolvimentos iniciais da agricultura têm seus indicativos indiretos.

A antropocoria, comentada no segundo capitulo, que ocorre amplamente entre os sítios no Jamari e Madeira, demonstra algumas evidências também no Jiparaná. ${ }^{64} \mathrm{Um}$ indicativo pertinente que cabe relacionar a nossa pesquisa é dado trabalhado por Clement (2003) sobre as origens das primeiras

\footnotetext{
${ }^{63}$ Datação calibrada (2 sigma, intercal.14c)

${ }^{64}$ Somente em um sitio, como mencionamos, ocorreu o fato de haver abundancia de palmeiras tanto dentro como fora do sitio, relatado em Bueno e Machado (2005). Não que não ocorra este fenômeno no Jipanará, mas o fato é de que lá a cobertura vegetal original foi praticamente toda degradada, substituída por pastagens e algumas lavouras, e sua identificação se torna ainda mais difícil.
} 
domesticações da palmeira Pupunha. O autor parte do principio de que (idem, 90)

(...) Domesticação de plantas: um processo co-evolucionário em que a seleção humana nos fenótipos de plantas em populações promovidas, manejadas ou cultivadas mudas as freqüências genotípicas as populações, tornando as plantas mais úteis e melhor adaptadas à intervenção humana na paisagem.(...)

Nas mudanças no tamanho da pupunha brava (Bactris gasipaes Var. chichagui) e nas raças primitivas de pupunha cultivada (Bactris gasipaes Var. gasipaes), mais as derivadas (raças Putamayo e Vaupés) o autor cita Rodrigues et al. (2004) que especula que tal vegetal possa ter sido primeiramente domesticado na região sudoeste da Amazônia, com data estimada de 10000 anos AP.(ibidem)

(...)atualmente a arqueologia da pupunha contrasta fortemente com os dados moleculares(...)Infelizmente a arqueologia ainda tem poucos registros da pupunha, ao contrário das informações atuais sobre as raças, de forma que ainda é cedo afirmar algo concreto, mas a biologia molecular levantou uma hipótese para ser testada no sudoeste amazônico.(...) (Ibidem, p.97)

Atualmente a genética molecular permite a analise genética da filogenia de plantas, e estas analises filogenéticas permitem examinar a historia da domesticação e dispersão de populações de plantas, bem como identificar o(s) centro(s) de origem das plantas cultivadas, assuntos de grande interesse em arqueologia. (Clement, 1999)

As primeiras relações entre esta categoria de dados e os arqueológicos já são encontradas em algumas publicações, como em Meggers e Miller (2003), Clement $(1999,2003)$ Allem (1997), todos relacionados ao estudo de caso da mandioca (Manihot esculenta subsp. esculenta). Segundo os principais estudos, e atualmente o modelo aceito, a subespécie Flabellifolia, que deu origem a mandioca cultivada, tem localização na transição da floresta-cerrado, hoje sul da Amazônia, entre Rondônia e o noroeste Mato-grossense, (Olsen e Schall 1999, 2001). Surpreende a localização atribuída atualmente para o centro de domesticação da Mandioca na América, pois é justamente a área 
onde se insere o sitio Encontro. E sendo pertinente a hipótese, cabe entender um pouco melhor o fato.

Em suma, são três as questões importantes para a botânica. Por exemplo, que espécies selvagens a mandioca é descendente, o local de origem, (distribuição geográfica do progenitor) e a origem da agricultura. Sendo que a mandioca se propaga pela vegetação, e considerando que o vegetal foi domesticado a partir de uma espécie selvagem, determinadas espécies cultivadas atualmente podem preservar a genética de seus ancestrais. Os dados apontam que duas espécies a $M$. pruinosa e a $M$. esculenta ssp. Flabellifolia são os ancestrais mais antigos da mandioca. Observações de mais de 150 anos, afirmam que estas espécies compartilham espaço geográfico, ecologia e morfologia e não entram conflito no ranking taxonômico. Também não se diferenciam em subespécies. É necessário explicitar que tanto $M$. pruinosa e a $M$. esculenta ssp. Flabellifolia são descendentes de um tronco ancestral em comum já que o fato implicaria em questões relacionadas à origem da agricultura. (Olsen e Schaal, 2001)

Estas espécies são geralmente encontradas em locais que circundam a floresta amazônica. Allem (1997) não atribui cronologia, mas indicia também que a agricultura surgiria em algum local entre Rondônia e Mato Grosso, devido ao fato de que na área foram encontrados em determinados locais uma concentração muito grande de ambas as espécies ancestrais. Olsen e Schaal (1999) e (2001) elegem também os estados de Rondônia e Mato Grosso, em especial a área de divisa, devido à presença de uma grande congruência do genoma entre populações locais de $M$. esculenta ssp. Flabellifolia e espécies cultivadas atualmente de $M$. esculenta ssp. esculenta.

Embora a data da domesticação da mandioca ainda seja não suficientemente documentada (Pearsall, 1992, traz datações para evidencias da mandioca entre 8000-6000 anos AP) e a da pupunha uma especulação baseada num modelo ecológico, ambas são bem antigas, e os indicativos para a região sudoeste a tornam atrativa para o entendimento de questões acerca o tema. (Clement, 2003) 
Uma vez que as relações dinâmicas entre o clima, o solo e a vegetação durante os últimos milênios sejam melhor compreendidas, os dados da biologia genética da mandioca, inseridos nesta problemática, podem proporcionar maior suporte para a comprovação da hipótese de que as possíveis evidências arqueológicas sejam encontradas na área.

Como relatamos, Haffer (1969) propõe para o local dois refúgios pleistocênicos. Embora existam fortes criticas a este modelo (Colinvaux et al. 2000) outros dados põem como valida a hipótese de que existiram em determinadas áreas documentadas ao sudoeste florestas com duração de milênios consecutivos. (Behling, 2001, Pessenda et al. 1998, Freitas et al. 2001, Burbridge et al.2004).

Clement (2003) ao avaliar o clima da região sudoeste a partir de Adams e Faure (1998), atribui que um clima mais constante nos últimos 5000 anos, ante as maiores instabilidades ocorridas desde o pleistoceno até o holoceno médio, e sendo a área atribuída para a domesticação da mandioca um local onde possivelmente a floresta/savana tiveram relações de contração e expansão, mas áreas florestadas normalmente ocorreram, e logo áreas de transição, argumenta com Harlan (1992), que postula que nestas zonas de transição entre floresta e savana, a maioria das espécies domesticadas são normalmente originais ou de zonas de transição ou de ecossistemas abertos.

E se retomarmos as discussões sobre os Tupi, tão importantes no Estado, lembramos que uma das hipóteses levantadas, apesar de especulativa, sobre a difusão da agricultura da mandioca é atribuída por Brochado (1973) ao grupo, sendo mais um indicador, mesmo que indireto que nos levam a crer que um dos locais onde houveram as primeiras experimentações da agricultura da mandioca possa ter ocorrido em algum ponto do sudoeste amazônico, entre Rondônia e Mato Grosso, por volta de 4500 anos AP. Acreditamos que o sudoeste da região amazônica possa ter tido um papel fundamental na origem e desenvolvimento de importantes cultivares que sustentaram populações précoloniais durante milênios em toda a área, até agora testemunhado em sítios líticos da fase Massanganá e lito-cerâmica no sítio Encontro. 
Mas fica ainda como desafio. Nas palavras conclusiva de Meggers e Miller (2003, p. 348) é proposto para os arqueólogos tentarem entender uma região tão rica em vestígios sobre o passado pré-colonial amazônico:

(...)La reconstrucción del desarrollo cultural en la amazonia representa un desafío excepcional para los arqueólogos (...) la escasez de la evidencia arqueológica hace necesaria de la extracción de la mayor cantidad de información posible de las características de la cerámica y su distribución temporal y espacial. El análisis cuantitativo y la seriación constituyen un enfoque; los detalle de decoración, forma de vasija un segundo; la teoría de deriva evolutiva un tercero. Una comparación de las interpretaciones resultantes con la evidencia ambiental, biológica e climática llama la atención a correlaciones que no son evidentes desde la perspectiva local. Esperamos que los arqueólogos sean incentivados a aceptar el desafío de refinar los métodos y elaborar las interpretaciones que hemos desarrollado.(...) 


\section{CONSIDERAÇÕES FINAIS}

$\mathrm{Na}$ mudança para o holoceno médio, um período com clima tornado-se mais estável, começam a aparecer manifestações que sugerem uma significante transformação no padrão de assentamento verificado no Estado de Rondônia. As evidências mais significativas foram: a possível experimentação agrícola, que incluía o manejo de palmeiras e a cultura incipiente de tubérculos; a agregação de populações em áreas nucleares em cabeceiras de afluentes e nos interflúvios, corroborada pela evidencia da presença de sítios com TPA; e o estabelecimento de um número maior de assentamentos localizados junto às várzeas e planícies de inundação, estes, maiores em relação aos sítios em terra firme.

Evidências diretas atestam para o Estado de Rondônia que há pelo menos 4600 AP experimentações agrícolas estavam sendo praticadas, atestadas na Fase Massanganá, em um afluente do Jamari.

$\mathrm{Na}$ região leste foram evidenciados uma série de sítios arqueológicos em ambiente de terra firme. Esta área compreende as planícies de inundação do rio Jiparaná se estendem até a terra firme, local de interflúvio entre os rios Jiparaná e Roosevelt/Aripuanã, que correm sentido norte, sendo importantes tributários do rio Madeira.

O Sítio Terra Queimada, localizado na terra firme, adjacente as planícies de inundação do rio Jiparaná, atestou uma ocupação de pelo menos 200 anos, a partir três datações radiocarbônicas. Apesar dessa duração, das dimensões e densidade arqueológica constatada, não foi evidenciado em nenhum local a TPA. Ao contrário do sítio Encontro, localizado na terra firme, no interflúvio dos rios Jiparaná e Roosevelt, onde ocupação se estende por pelo menos 200 anos, entre 4400-4200 e corresponde ao registro de TPA mais antigo com evidência cerâmica da Amazônia.

Os dados do sítio Encontro, aliado a dados taxonômicos relativos à mandioca, podem sugerir que o sudoeste amazônico, mais precisamente o Estado de Rondônia e o noroeste de Mato Grosso, podem ter um papel influente na elucidação de problemas relacionados à origem da produção de mandioca. 
Considerando também os indícios da fase Massanganá, sugerimos que a área também pode ter um papel importante em relação à origem da agricultura.

Além disso, a quantidade de polidores e amoladores evidenciados nas margens dos igarapés e rios da região entre Jiparaná e Pimenta Bueno, junto ao fato da presença de uma quantidade altíssima de machados polidos localizados tanto in situ, como em mãos de coleções particulares, sugere a ampla utilização desses artefatos em atividades provavelmente relacionadas a modificação da paisagem pelo homem - preparo de roças, derrubada de árvores, etc.

Apesar das críticas levantadas às hipóteses dos fatores limitantes em relação à ocupação humana na Amazônia, a maior parte dos autores (Carneiro 1970, Lathrap 1970, Meggers 1971 e 2001, Roosevelt 1989) concordam que a várzea e a terra firme apresentam oportunidades e limitações distintas. A várzea é caracterizada como capaz de sustentar os maiores assentamentos, devido à relativa fertilidade do solo e facilidade de acesso aos recursos da fauna aquática. Todavia, apesar de ser mais fértil, a várzea é um ambiente de alto risco, que apresenta desvantagens para a ocupação, como a impossibilidade de se cultivar ao longo de todo o ano, devido às inundações, a possibilidade de inundações extremas ocasionais, que inundam mesmo os terrenos mais altos (Carneiro 1995, Denevan 1996). Logo, a incerteza existente nas várzeas quanto às cheias faria com que as sociedades pré-coloniais não pudessem depender exclusivamente deste ecossistema para agricultura, e utilizariam a terra firme de forma complementar (Carneiro 1995, Denevan 1996).

Concordamos com Kämpf e Kern (2003) e Kern et al (2003) quando afirmam que 0 tipo de solo parece não ter sido um fator determinante para 0 estabelecimento de assentamentos de grupos pré-históricos. O sítio Encontro, apesar de trazer um dado ainda singular na arqueologia amazônica, pode colaborar com a idéia de que sítios menores, com TPA, poderiam estar relacionados a aldeias pequenas, permanentes, nos interflúvios, já o sítio Terra Queimada, provavelmente, estaria ligado às aldeias maiores em áreas adjacentes a várzea que não formaram TPA, por motivos ainda não especulados. Mas cabe mencionar que existe ainda um exemplo etnográfico, 
constatado na tribo Surui, de língua pertencente ao tronco Tupi, família Mondé. Este povo está locado na Terra Indígena Sete de Setembro, entre Cacoal-RO e Rondolândia-MT, a poucos quilômetros do sítio Encontro. A organização social da tribo é divida em duas metades: a da roça e a da floresta. E esta oposição é constada também nas regras de casamento e na realização de ritos. (Panewa, 2002) A manifestação arqueológica desta ocupação poderia resultar em sítios, tanto na terra firme(floresta) quanto em áreas adjacentes à várzea(roça).

Os primeiros indícios cerâmicos ocorridos no Estado, atribuídos a fase Bacabal (Miller, 1992 e 1999), podem estar ligados a sociedades economicamente distintas em relação ao que é demonstrado nos sítios cronologicamente subseqüentes. Seu padrão de assentamento difere sob vários aspectos, o mais característico, por ocuparem as planícies aluviais do Pantanal do Guaporé, estabelecidos nos sambaquis, com cronologia estabelecida em $3885 \pm 270$ $4335 \pm 240$. Esta fase parece colaborar com um fato que começa a ficar recorrente na história da Amazônia: as primeiras manifestações cerâmicas estão relacionadas a grupos especializados na obtenção de recursos aquáticos, tanto nos rios, quanto na várzea, assim como na costa atlântica.

Com exceção do baixo amazonas, nos demais locais, para os milênios que se sucedem há uma carência de dados arqueológicos. Neves (2003), já aponta que este caso pode estar relacionado mais com uma falta de visibilidade arqueológica destes sítios do que a pouco freqüência ou até inexistência de assentamentos neste período cronológico em determinadas áreas.

Em Rondônia, as evidências cerâmicas seguintes estão relacionadas à ocupação do sítio Encontro, no leste do Estado, ocorrendo por volta de 4200 AP, e com uma cultura material que pode ser inserida na Tradição Tupiguarani. Ainda é necessário trabalhar muito para de entendermos de uma maneira mais clara a vasta variabilidade que comporta o Tupiguarani arqueológico. Nas classificações realizadas, principalmente na região do rio Madeira, fica evidente a semelhança que os conjuntos cerâmicos das diversas filiações culturais possuem. A fase Urucuri é um exemplo, quando aparece na tradição Jamari (Miller et al 1992), subtradição Jatuarana (Miller 1999) e na fase Guarita (Miller, 
1987b). Mais dados cronológicos e uma classificação cerâmica ao mesmo tempo mais detalhada e unificada, mais testes, ainda são necessários para refinar a presença destas fases no rio Madeira para quem sabe termos uma melhor compreensão da dinâmica populacional da área. Os dados que temos para a região Sudoeste da Amazônia, a presença deste tupi de forma ampla, próximo as bordas da floresta e o cerrado e indícios de ocupação bem antiga coincidindo com as informações lingüísticas, inserem a região como importante ponto de discussão para o levantamento de informações sobre as antigas expansões Tupi.

Existem ainda hiatos, como entre os primeiros indícios da fase Bacabal e do sitio Encontro, e a manifestação seguinte é encontrada há 2900 AP, no médio rio Madeira, representada pela Subtradição Jatuarana, pertencente à Tradição Polícroma da Amazônia (Miller, 1999). Também inserida nesta grande tradição estão as fases da Tradição Jamari. A seqüência cronológica elaborada por Miller et alli (1992) e Miller (1999) é uma das mais refinadas para a Amazônia, mas ao mesmo tempo é uma das menos discutidas.

Estas ocupações cerâmicas podem estar vinculadas a um espraio de populações agricultoras que utilizam os recursos tanto da várzea, quanto da terra firme. A partir de 2900 AP é presenciado um aumento em numero e tamanho de assentamentos, a ocorrência de Terra Preta Arqueológica mais freqüente e significativa, em diferentes locais do Estado, mais assídaos em locais ligados a várzea (Tradição Jamari e subtradição Jatuarana). Este seria um produto final do que pode ter sido iniciado na terra firme dos afluentes do rio Jamari, e da Terra Firme no interflúvio Jiparaná/Roosevelt, e este processo, dos primeiros indícios da agricultura até seu pleno estabelecimento, seriam os principais indícios do inicio do grande espraio de populações a partir desta cronologia. Outros fatores ainda não avaliados, como os que indicariam uma maior complexidade social nos sítios do rio Madeira, podem auxiliar ainda na validação desta hipótese.

No entanto, nosso estudo que criticou a tendência de homogeneizar a variabilidade adaptativa e cultural e a minimizar a importância de determinadas evidências arqueológicas, em pesquisas baseados em linhas do evolucionismo 
IMAGEM 56 figua cronolgias e tpa 
linear, também realizou-o de certas forma. Este trabalho tentou interpretar os dados que estão disponíveis a partir de um olhar amplo, e portanto, não deixa claro como e porque determinados sistemas de agricultura, padrões de assentamento, se diferenciaram, se espraiaram e se intensificaram. Ainda temos muitos dados para acessar, assim como só esta iniciada a retomada da discussão sobre a importância da arqueologia realizada no sudoeste Amazônico.

O caso do sítio Encontro é interessante, na medida em que é um exemplo dos dados que somente agora estão ficando disponíveis em relação às ocupações dos interflúvios de importantes rios amazônicos. Estes não estavam a disposição na elaboração dos grandes modelos de explicação da dinâmica cultural preteria do território Amazônico. Este é um quadro inicial, acreditamos que um melhor entendimento da ocupação destas áreas de interflúvio, principalmente este, entre os rios Jiparaná e Roosevelt/Aripuanã, podem nos ajudar a esclarecer alguns porquês de diferentes processos culturais ocorridos no sudoeste da Amazônia pretérita.

Podemos estar iniciando o entendimento de um complexo processo que se deu a partir de 5000 anos AP no sudoeste amazônico. Se existe relação direta com as mudanças climáticas, não se sabe ao certo, mas ao contrario que se pensava, parece que o solo, seja rico, seja pobre, não foi um fator decisivo na consolidação de aldeias. A farta ocorrencia de sítios na terra firme da bacia do Jiparana, e sobretudo a diversidade atestada nas diferentes fases deve ser resultado de um longo processo de ocupação na área que até o momento tem o sítio Encontro como representante mais antigo

Concluindo, pensamos que idiossincrasias antipronapistas que desdouram nossa produção acadêmica, e que até hoje atingem aqueles que estão entrando na arqueologia já devem começar a ser repensadas. Ainda mais, já ultrapassamos o momento de ficar inconscientemente criticando um grande projeto, e que graças o ele, temos hoje uma idéia de unicidade do registro arqueológico brasileiro. Já temos condições de discutir com o estabelecido, temos condições não só de criticar mais sim de propor alternativas(quando necessárias!), como esta dissertação se propôs, para então só assim 
iniciarmos uma nova etapa na pesquisa arqueológica nacional, como vem acontecendo em alguns trabalhos publicados recentemente pela academia. 


\section{BIBLIOGRAFIA}

Absy, M.L., Van der Hammen, T.,. Some palaeoecological data from Rondonia, southern part of the Amazon basin. Acta Amazonica 6, 1976

Absy, M.L., Cleef, A.M., Fornier, M., Servant, M., Siledine, A., Da Silva, M.F., Soubies, F., Suguio, K., Turcq, B., Van der Hammen, T.,1991. Mise en evidence de quatre phases d'ouverture de la foret dense dans le sud-est de l'Amazonie au cours des 60,000 dernieres anne'es. Premiere comparaison avec d'autres regions tropicales. Comptes Rendus Academie Scientique Paris 1991

Almeida. F.O. O complexo Tupi da Amazônia oriental. Dissertação de Mestrado, MAE/USP, 2008

Andrade, A.. Investigacion arqueológica dos antrosolos de Araracuara. Fundación de Investigaciones Arqueológicas Nacionales Banco de la República. 1986.

Balée W. The culture of Amazonian forests. In Resource management in Amazonia: indigenous and folk strategies. Adv. Econ. Bot. 1989

Behling, H., Hooghiemstra, H., Negret, A.J.,Holocene history of the rain forest from Laguna Piusbi, southern Pacific lowlands of Colombia. Quaternary Research 50, 1998

Behling, H, Costa, M. L.. Holocene Environmental Changes from the Rio Curua' Record in the Caxiuana Region, Eastern Amazon Basin. Quaternary Research 53, pp. 369-377, 2000.

Ballester, M.V.R., Victoria, D. C., Krusche, A.V., Coburn, R., Victoria, R.L, Richey, J.E.; Logsdon, M.G., Mayorga, E., Matricardi, E. A remote sensing/GIS-based physical template to understand the biogeochemistry of the Ji-Paraná river basin (Western Amazônia). Remote Sensing of Environment 87, 2003.

Boutton, T.W. Stable carbon isotope ratios of natural materials.. Atmospheric, terrestrial, marine, and freshwater environments. In: Coleman, D.C.; Fry, B. (Eds). Carbon isotope techniques. New York: Academic Press. 1991

BRASIL. Departamento Nacional da Produção Mineral. Projeto Radambrasil. Folha SC.20-Porto Velho. Rio de Janeiro, 1976 
BROCHADO, J.J.J.P. Alimentação na floresta tropical. IFCH, caderno n. 2. Universidade Federal do Rio Grande do Sul, Porto Alegre, RS, 1977

An Ecological Model of the Spread of Pottery and Agriculture into Eastern South America. PhD Tesis. University of Illinois at Urbana-Champaign, 1984.

Bueno, L.R, Machado, J. Relatório Final de Levantamento Arqueológico da área de implantação do sistema de Transmissão 230kV Ji-Paraná/ Pimenta Bueno/ Vilhena - RO. 2005

Burbridge, G. Mayle, F.E., Killeen, T.J. Fifty-thousand-year vegetation and climate history of Noel Kempff Mercado National Park, Bolivian Amazon. Quaternary Research, 2004

Caldarelli, S. B.; Costa, F. A.; Kern, D. C. Assentamentos a céu aberto de caçadores coletores datados da transição Pleistoceno final/ Holoceno inicial no Sudeste do Pará. Revista de Arqueologia, 18, 2005

CHMYZ, I. (ed.) Terminologia Arqueológica Brasileira para Cerâmica. Cadernos de Arqueologia ( $\mathrm{n}$ 1); Universidade Federal do Paraná, 1976

Carneiro R.L. Theory on the origin of the state. Science. 1970

Carneiro, R.L. The cultivation of manioc among the Kuikuru Indians of the Upper Xingu. In: Hames R.B, Vickers W.T., editors. Adaptive responses in native Amazonians. Academic Press; New York, NY: 1983. pp.

Clement, C.R. Fruit trees and the transition to food production in Amazonia. In: Balée W, Erickson C., editors. Time and complexity in historical ecology: studies in the neotropical lowlands. Columbia University Press; New York, NY: 2006. pp. 165-185.

Colinvaux, P.A.,. Quaternary environmental history and forest diversity in the neotropics. In: Jackson, J.B.C., Budd, A.F., Coates, A.G. (Eds.), Evolution and Environment in Tropical America. The University of Chicago Press, Chicago, pp. 359\}405. 1996

Colinvaux, P.A., De Olliveira, P.E., Moreno, J.E., Miller, M.C., Bush, M.B.,. A long pollen record from lowland Amazonia: Forest and cooling in glacial times. Science 274, 1996

Denevan, W. Stone versus metal axes: the ambiguity of shifting cultivation in the prehistoric Amazonia. Journal of the Steward Anthropological Society, 20, 1992 
The aboriginal population of Amazonia. In: DENEVAN, W.

(ed.) The native population of the Americas in 1492. University of Wisconsin Press, Madison, 1992.

Semi-intensive pre-European cultivation and the origins of Anthropogenic Dark Earths in Amazonia. In: GLASER, B. \& WOODS, W.I. (eds.). Amazonian Dark Earths: Explorations in space and time. Springer, Berlin, 2004.

ELETRONORTE, Centrais Elétricas do Norte do Brasil S.A. Inventário Florístico/ Florestal Linha de Transmissão 230kV Ji-Paraná/ Pimenta Bueno/ Vilhena. LEME Engenharia, 2002.

EMBRAPA. Centro Nacional de Pesquisa de Solos. Sistema Brasileiro de Classificação de Solos. Embrapa Solos, Rio de Janeiro, 1999.

Evans, C. \& Meggers, B.,. Archaeological investigations on the río Napo, Eastern Ecuador. Smithsonian Contributions to archaeology, 6, 1968.

Freitas, H.A., Pessenda, L.C.R., Aravena, R., Gouveia, S.E.M., Ribeiro, A., Boulet, R. Late Quaternary vegetation dynamic record in southern Amazon basin inferred from carbon isotopes in soil organic matter. Quaternary Research 55, 39- 46, 2001.

FIERO. Rondônia - Perfil e diretrizes de desenvolvimento industrial e de infra-estrutura. Porto Velho. Edigral, 1995.

FORD, J. A Comparison of Formative Cultures in the Americas: Diffusion or the Psychic Unityof Man? Smithsonian Contributions to Anthropology 11, Washington, D.C. 1969

Glaser B, Woods W.I. , editors. Amazonian dark earths: explorations in space and time. Springer, 2004.

Guffroy, J. El Horizonte corrugado: correlaciones estilísticas y culturales. Bulletin de l'Institut Français d'Études Andines, n³5 vol3, 2006

Hafer, J., Speciation in Amazonian forest birds. Science 165, 1970

HECKENBERGER, M.; NEVES, E. \& PETERSEN, J. De Onde Surgiram os Modelos. As Origens e expansões Tupi na Amazônia Central. Revista de Antropologia; USP; v. $41 ; n^{\circ} 1 ; 1998$. 
Heckenberger M.J, Petersen B.J, Neves E.G. Village size and permanence in Amazonia: two archaeological case examples from Brazil. Latin American. Antiquity. 1999

IBGE. Produção da vegetação e da silvicultura, 1997

IBGE. Anuário Estatístico do Brasil, 1997.

Kämpf, N.; Woods, W.I.; Sombroek, W.; Kern, D.C. \& Cunha, T.J.F. Classification of Amazonian Dark Earths and other ancient anthropic soils. In: Lehmann, J.; Kern, D.C.; Glaser, B. \& Woods, W.I., Amazonian Dark Earths. Origin, properties and management. Kluwer Academic Publishers, 2003.

Kern, D.C. Caracterização Pedológica de Solos com Terra Preta Arqueológica na Região de Oriximiná, Pará. Dissertação de mestrado.UFRGS, Faculdade de Agronomia, Porto Alegre. 1988.

Geoquimica e pedogeoquimica de sitios arqueológicos com Terra Preta na Floresta Nacional de Caxiuaná (Portel-Pará). Tese de Doutorado. Universidade Federal do Pará, Belém, 1996.

Kern, D.C.; D’aquino, G; Rodrigues, T.E.; Frazão, F.J.; Sombroek, W.; Myers, T.P.; NeveS, E.G. Distribution of Amazonian Dark Earths in the Brazilian Amazon. In: Lehmann, J.; Kern, D.C.; Glaser, B. \& Woods, W.I. Amazonian Dark Earths. Origin, properties and management. Kluwer Academic Publishers, Dordrecht, 2003.

Kern, D.;D'Aquino, G.;Rodrigues, T.E.;Frazdo, F.J.L.;Sombroek, W.;Myers, T.P.; Neves, E.G. The distribution of Amazonian dark earths in the Brazilian Amazon. In: Lehmann J, et al., editors. Amazonian dark earths: origins, properties, and management. Kluwer Academic Publishers; Dordrecht, The Netherlands: 2003.

Kern, D.C. \& Kämpf, N. Antigos assentamentos indígenas na formação de solos com Terra Preta Arqueológica na região de Oriximiná, Pará. Revista.Brasileira de Ciencias do Solo, 13,1989.

Kern, D.;D'Aquino, G.;Rodrigues, T.E.;Frazdo, F.J.L.;Sombroek, W.;Myers, T.P.; Neves, E.G. The distribution of Amazonian dark earths in the Brazilian Amazon. In: Lehmann J, et al., editors. Amazonian dark earths: origins, properties, and management. Kluwer Academic Publishers; Dordrecht, The Netherlands: 2003. 
Kipnis, R.; Caldarell,i S. B; Oliveira, W. C. Contribuição para a cronologia da colonização amazônica e suas implicações teóricas. Revista de arqueologia, 18, 2005

Lathrap, D. The Upper Amazon, 1970.

. O Alto Amazonas. Verbo, Lisboa, 1975.

. Our Father the Cayman, Our Mother the Gourd: Spinden Revisited or a Unitary Model for the Emergence of Agriculture in the New World. In: Reed C.(ed.) Origins of Agriculture, Mouton, 1977

Lehmann J, Kern D, Glaser B, Woods W. (Ed.). Amazonian dark earths: origins, properties, and management. Kluwer Academic Publishers; Dordrecht, The Netherlands: 2003.

LEMOS, A., SANTOS, P.B.. Manual de Descrição e Coleta de Solos em Campo., Ed. SBCS/SNLCS, Campinas-SP, 1996.

Lima H, Neves E.G, Petersen J.B. A fase Açutuba: um novo complexo cerâmico na Amazônia Central. Arqueología Suramericana/Arqueologia Sulamericana. 2006

Magalhães, M. P.A Physis da Origem: o sentido da história na Amazônia. Museu Paraense Emílio Goeldi, Belém, 2005.

Meggers, B.J. Amazonia: Man and Culture in a counterfeit paradise. Revised edition. Smithsonian Institution Press, Washington, 1996. 214p.

Meggers, B.J. \& Miller, E.Th. Hunter-gatherers in Amazonia during the Pleistocene-Holocene transition. In: Mercader, J. (ed.) Under the canopy: The archaeology of tropical rain forests. Rutgers University Press, New Brunswick, 2003.

MEGGERS, B. \& EVANS, C. Archaeological Innvestigation in the Mouth of theAmazon. Smithsonian Institution; Government Printing Press; Washington; 1957.

MEGGERS, B.J. A Reconstrução da Pré-História Amazônica. Universidade de São Paulo; 1974; p.1-19.

Vegetation fluctuation and prehistoric cultural adaptations in Amazonia: some tentative correlations. World Archaeology, 8 (3), 1977

Climatic Oscillation as a Factor in the Prehistory of Amazonia. American Antiquity, 44 (2), 1979 
Miller, E. Th. Pesquisas Arqueológicas no Território Federal de Rondônia.

Relatório Preliminar. Secretaria de Esportes e Turismo do estado de Rondônia. 1980.

. História da cultura indígena do Guaporé(Mato Grosso e Rondônia). Dissertacao de Mestrado, PUCRS, 1983

.Inventário Arqueológico da Bacia e Sub-bacias do Rio Madeira -

1974-1987. Consórcio Nacional de Engenheiros Construtores S.A.1987a

Relatório do Programa de Estudos de Viabilidade Arqueológica

nas Áreas de inundação e de influência da U.H.E. Ji-Paraná - 1986-1987.

Consórcio Nacional de Engenheiros Consultores S.A.1987b.

Projeto de Avaliação do potencial arqueológico na área de influência da rodovia BR-429- Presidente Médici - Costa Marques. Governo do Estado de Rondônia. Secretaria do Estado do Planejamento e Coordenação geralSEPLAN. 1987c.

Adaptação agrícola pré-histórica no Alto Rio Madeira In: MeggersB.J (Org.). Prehistoria Sudamericana. Nuevas Perspectivas. 1 ed. Washington, D.C.,: TARAXACUM, 1992

A limitação ambiental como barreira à transposição do período formativo no Brasil. Tecnologia, produção de alimentos e formação de aldeias no sudoeste da Amazônia. In: Ledergerber-Crespo, P. (Ed.) Formativo Sudamericano, una revaluación. Ediciones Abya-Yala, QuitoEquador, 1999.

Miller, et. al. Arqueologia nos Empreendimentos Hidrelétricos da Eletronorte. Brasília, Eletronorte, 1992.

Mora, S., Herrera, L.F., Cavelier F., I. \& Rodriguez, C. Cultivars, anthropic soils and stability. A preliminary report of archaeological research in Araracuara, Colombian Amazonia. Pittsburgh, University of Pittsburgh Latin American Archaeology Reports No. 2. 1991.

Myers, T.P.; Denevan, W.M.; Winklerprins, A. \& Porro, A. Historical perspectives on Amazonian Dark Earths. In: Lehmann, J.; Kern, D.C.; Glaser, B. \& Woods, W.I. Amazonian Dark Earths. Origin, properties and management. Kluwer Academic Publishers, Dordrecht, 2003. 
Neves, E.G.; Petersen, J.B.; Bartone, R.N. \& Silva, C.A. da. Historical and socio-cultural origins of Amazonian Dark Earths. In: Lehmann, J.; Kern, D.C.; Glaser, B. \& Woods, W.I. Amazonian Dark Earths. Origin, properties and management. Kluwer Academic Publishers, Dordrecht, 2003.

Neves, E.G.; Petersen, J.B.; Bartone, R.N. \& Heckenberger, M.J. The timing of Terra Preta formation in the Central Amazon: Archaeological data from three sites. In: Glaser, B. \& Woods, W.I. (eds.). Amazonian Dark Earths: Explorations in space and time. Springer, Berlin, 2004.

Neves, E.G.; Petersen, J.B. The political economy of pre-Columbian Amerindians: landscape transformations in central Amazonia. In: Balée W, Erickson C. , editors. Time and complexity in historical ecology: studies in the neotropical lowlands. Columbia University Press; New York, NY: 2006

Neves, E.G.;Petersen, J.B.;Bartone, R.N.; Heckenberger, M.J. The timing of terra preta formation in the Central Amazon: archaeological data from three sites. In: Glaser B, Woods W. , editors. Amazonian dark earths: explorations in space and time. Springer; Berlin, Germany: 2004

NOELLI, F. S. As Hipóteses sobre o Centro de Origem e Rotas de Expansão dos Tupi. Revista de Antropologia, 39 (2); São Paulo; 1996; p. 7-53.

Oliver, J. The archaeology of forest foraging and agricultural production in Amazonia. In: Mcewan, C.; Barreto, C. \& Neves, E.G. (eds.) Unkown Amazon. The British Museum Press, London, 2001.

Olsen,K,Schaal.B..Evidence on the origin of cassava: phylogeography of Manihot esculenta. Proceedings of the National Academy of Sciences, USA, 96, p. 5586-5591. 1999

ORTON, Clive, TYERS, Paul \& VINCE, Alan. La Cerámica en Arqueología: Crítica ( Grijalbo Mondadori, S.A.), Aragó, Barcelona, 1997.

Pearsall, D. M. The Origins of Plant Cultivation in South America. In: COWAN, C. Wesley; WATSON, Patty Jo. The Origins of Agriculture: an international perspective. Washington and London: Smithsonian Institution, 1992.

Pessenda L.C.R.,. Gomes, B.M Aravena,R. Ribeiro, A.S. Boulet R., Gouveia S.E.M. The carbon isotope record in soils along a forest-cerrado ecosystem transect:implications for vegetation changes in the Rondonia state, southwestern Brazilian Amazon region. The Holocene 8,5 (1998) pp. 599-603 
Pessenda L.C.R.,. Rosolen V., Aravena,R. Ribeiro, A.S. Boulet R., Gouveia E. M., Lamotte, M. Origin and dynamics of soil organic matter and vegetation changes during the Holocene in a forest-forest-savanna transition zone, Brazilian Amazon region. The Holocene 2001; 11; 250

Petersen, J.B.; Neves, E. \& Heckenberger, M.J. Gift from the past: Terra Preta and prehistoric amerindian occupation in Amazonia. In: Mcewan, C.; Barreto, C. \& Neves, E.G. (eds.) Unkown Amazon. The British Museum Press, London, 2001.

Piperno, D. R., And D. M. Pearsall.. The origins of agriculture in the Lowland Neotropics. Academic, New York, 1998.

Rice, P. Pottery Analysis, a Sourcebook. University of Chicago Press; 1987.

Roosevelt, A.C. Determinismo ecológico na interpretação do desenvolvimento social indígena da Amazônia. In: Neves, W. (ed.) Origem, adaptações e diversidade biológica do homem nativo da Amazônia. Museu Paraense Emílio Goeldi, Coleção Emílie Snethlage, 1991. p.103-159.

Amazonian anthropology: Strategy for a new synthesis. In: Roosevelt, A.C. (ed.) Amazonian indians from prehistory to the present: Anthropological perspectives. University of Arizona Press, Tucson, 1994

Arqueologia Amazônica. In: CUNHA, M.C. (org.) História dos índios no Brasil. Cia. das Letras, São Paulo, 2002.

The Lower Amazon: A dynamic human habitat. In: Lentz, D.L. (ed.) Imperfect Balance: Landscape transformations in the precolumbian Americas. Columbia University Press, New York, 2000. p.455-491.

Determinismo ecológico na interpretação do desenvolvimento social indígena da Amazônia. NEVES, W. A. (Org.). Belém: MPEG-CNPq-SCT-PR; (Coleção Snethlage); 1991

Arqueologia Amazônica. In História dos Índios no Brasil. CUNHA, M.C. da (Org). São Paulo. Companhia da Letras; Secretaria Municipal de Cultura; FAPESP; 1992.

Roosevelt, A.C., Costa, M.L., Machado, C.L., Michab, N., Valadas, H., Feathers, J., Barnett, W., Silveira, M.I., Henderson, A., Silva, J., Chernoff, B., Reese, D.; Holman, J.A.; Toth, N. \& Schick, K. Paleoindian cave dwellers in the Amazon: The peopling of the Americas. Science, 272:373-384, 1996. 
Rye, O. S. Pottery Technology: Principles and Reconstruction. Australian National University; 1981.

Rodrigues, A. D.. A Classificação do Tronco Lingüístico Tupí. Revista de Antropologia 12. São Paulo, 1965.

Scandolara, J.E., Rizzotto, G.J., Amorim, J.L. Mapa geológico do Estado de Rondônia. Escala 1:1.000.000. Porto Velho: CPRM, 1998.

SCHIFFER, M. B. \& SKIBO, J. The Explnation of Artifact Variability. American Antiquity; 62 (1); 1997; p. 27-50.

Schiffer, M. B. \& SKIBO, J. Theory and Experiment in the Study of Technological Change. Current Anthropology, 28 (5): 59-622. 1987.

Theory and Experiment in the Study of Technical Change. In:

SCHIFFER, M. B. (Ed.) Technological Perspectives on Behavioral Change. Tucson: university of Arizona Press, p. 40-76, 1992.

SCIENTIA CONSULTORIA CIENTÍFICA, Projeto Arqueologia Preventiva na Expansão do Sistema de Transmissão Acre-Rondônia, subprojeto 1: Salvamento Arqueológico na LT 230kV Ji-Paraná - Pimenta Bueno - Vilhena Rondônia, Caldarelli, S.(org) 2005

Relatório parcial do Projeto Arqueologia Preventiva na Expansão

do Sistema de Transmissão Acre-Rondônia, subprojeto 1: Salvamento Arqueológico na LT 230kV Ji-Paraná - Pimenta Bueno - Vilhena - Rondônia, Caldarelli,S. Cruz, D.(org), 2008

Schmitz, P.I. Migrantes da Amazônia: a Tradição Tupiguarani. Arqueologia do RGS, Brasil - Documentos (São Leopoldo) 5; 1991; p.31-66.

Shepard, A. O. Ceramics for the archaeologist. Washington: Carnegie Institute of Washington, 1956.

Silverwood-Cope, Peter L. Os Makú : povo caçador do Noroeste da Amazônia. Brasília, UnB, 1990.

Sifeddine, A., Bertrand, P., Fournier, M., Martin, L., Servant, M., Soubies, F., Suguio, K., Turcq, B.,. La sedimentation organique lacustre en milieu tropical humide (CarajaH s, Amazonie orientale, BreHsil): relation avec leschangements climatiques au cours des 60,000 dernieres annees. Bulletin Societe Geologie France 1994

SKIBO,J \& SCHIFFER, M.B. Understanding artifact variability and change: a behavioral framework. In:M.B. SCHIFFER (ed.) Antrhopological Perspectives in Technology. Albuquerque, University of New México Press, p. 139-150. 1991. 
Stuiver, M., Reimer, PJ. Calib Radiocarbon Calibration Program. Versão 5.1, Copyright 1986-2006

Simões, Mário Simões, Araujo-Costa, F. Áreas da Amazônia Legal Brasileira para pesquisa e cadastro de sítios arqueológicos. Publicações Avulsas do Museu Goeldi, no 30, Belém, 1978

Sombroek, W.; D. Kern; T. Rodrigues; M.S. Cravo; T.J. Cunha; W. Woods \& B. Glaser. Terra Preta and Terra Mulata: pre-Columbian Amazon kitchen middens and agricultural fields, their sustainability and their replication. Symposium 18 - Anthropogenic factors of soil formation,17th World Congress of Soil Science in Bangkok, Thailand, 14-21 August 2002.

Stewart, J.(ed.) Handbook of South American Indians: the tropical forest tribes (vol.3). Smithsonian Institution; bureau of American Ethnology; Coper Square; New York; 1963.

Urban, G. A história da cultura Brasileira segundo as linguas nativas. In: CARNERIO DA CUNHA, M. M. (org.), Índios no Brasil, São Paulo, Companhia das Letras, 1992.

Woods, W. I. Development of Anthrosol Research. In: Amazon Dark Earth: Origin,Properties, Management. J. Lehmann, Kern, D., Glaser, B., Woods, W., Kluwer Amazonian Dark Earths: origin, properties, managements, Academic Publishers, 2003

Woods W.I, McCann J. The anthropogenic origin and persistence of Amazonian dark earths. Yearbook of the Conference of. Latin. American. Geographers. 1999 
Anexo 1 - FICHA DE ANÁLISE CERÂMICA

\begin{tabular}{|c|c|}
\hline Atributo & Variáveis \\
\hline $\begin{array}{c}\text { Número de } \\
\text { Proveniência }\end{array}$ & Localização do fragmento no sítio. \\
\hline Categoria & $\begin{array}{c}\text { Não identificado, Borda,Base,Bolota de argila,Roda de fuso,Forma } \\
\text { conjugada ,Carena, Flange, Cachimbo, Aplique, Placa, Suporte de tampa, } \\
\text { Adorno, Ombro, }\end{array}$ \\
\hline $\begin{array}{l}\text { Técnica de } \\
\text { Manufatura }\end{array}$ & Não identificada Acordelada Modelada Acordelada + Modelada \\
\hline Antiplástico & Associações entre: Cerâmica, Carvão Concha, Mineral, Areia, Ausente, \\
\hline Composição do & \\
\hline $\begin{array}{c}\text { Antiplástico } \\
\text { Mineral }\end{array}$ & Associações entre Quartzo, Hematita, Mica, Feldspato, \\
\hline $\begin{array}{l}\text { Dlametro do } \\
\text { Antiplástico }\end{array}$ & $<1 \mathrm{~mm},>=1<3 \mathrm{~mm},>=3<5 \mathrm{~mm},>5 \mathrm{~mm}$ \\
\hline $\begin{array}{c}\text { Freqüência do } \\
\text { Antiplástico }\end{array}$ & 12 variáveis em relação a quantidade de antiplástico presente no fragmento \\
\hline $\begin{array}{l}\text { Ordenação do } \\
\text { Antiplástico }\end{array}$ & 5 variáveis relativas a homogeneidade das dimensões dos antiplásticos. \\
\hline Queima & Completa, incompleta, Redutora, Oxidante \\
\hline
\end{tabular}




\section{Tratamento de}

Superficie

Polimento

Engobo

Barbotina

Marcas

Sinais de Uso

Estado de

Conservação

Borda Morfologia

Borda Inclinação

Borda Espessura

Lábio

Espessura do

Lábio
Alisamento, FE, FE e AF

Presente/Ausente, FI,FE,AF

Presente/Ausente, FI,FE,AF Vermelho Branco Laranja Preto Marrom Vermelho e branco Branco e laranja

Presente/Ausente, FI,FE,AF

Ausente,Folha, Queima de confecção,queima posterior, estrias de alisamento, Marca de rolete, furo, cestaria,outro

Ausente Película queimada FI (alimento) Fuligem AF Reciclagem Atrito FI,

$$
\text { Craquele }
$$

Conservado, Erodido AF, FI, FE

Não identificada, Direta, Extrovertida, Introvertida, Cambada, Vasada, Extrovertida com ponto angular, Extrovertida com ondulação

Não identificada, Vertical, Inclinada internamente, Inclinada externamente Não identificada, Direta, Expandida, Reforçada internamente, Reforçada externamente, Reforçada, Dobrada Contraída

Não identificado, Arredondado, Plano, Apontado, Biselado 
Diâmetro

Base

Diâmetro da Base

Espessura do

Fragmento

Decoração

Plástica

Decoração

Pintada

Local da

Decorção FE

Local da

Decorção FI

Cor da Pasta

\section{Em centímetros}

Não identificada, Convexa, Plana, Côncava, Anelar, Em pedestal

Em centímetros

Em centímetros

Ausente, Corrugado, Inciso, Ungulado Roletado Digitado Escovado, Entalhado (instrumento), Acanalado,

Ausente ou Associações entre Pintura vermelha, Pintura branca, Pintura preta e engobo.

Não identificado, Lábio, Borda, Gargalo Ombro, Parede, Base, Outros,

Não identificado, Lábio, Borda, Gargalo Ombro, Parede, Base, Outros,

Não identificado, laranja, marrom A, vermelho, preto, marrom B,amarelo

AF - Ambas as faces FE - Face externa FI - Face Interna 
ANEXO 2 - Relação entre Cor da pasta/freqüência/ordenação do antiplástico

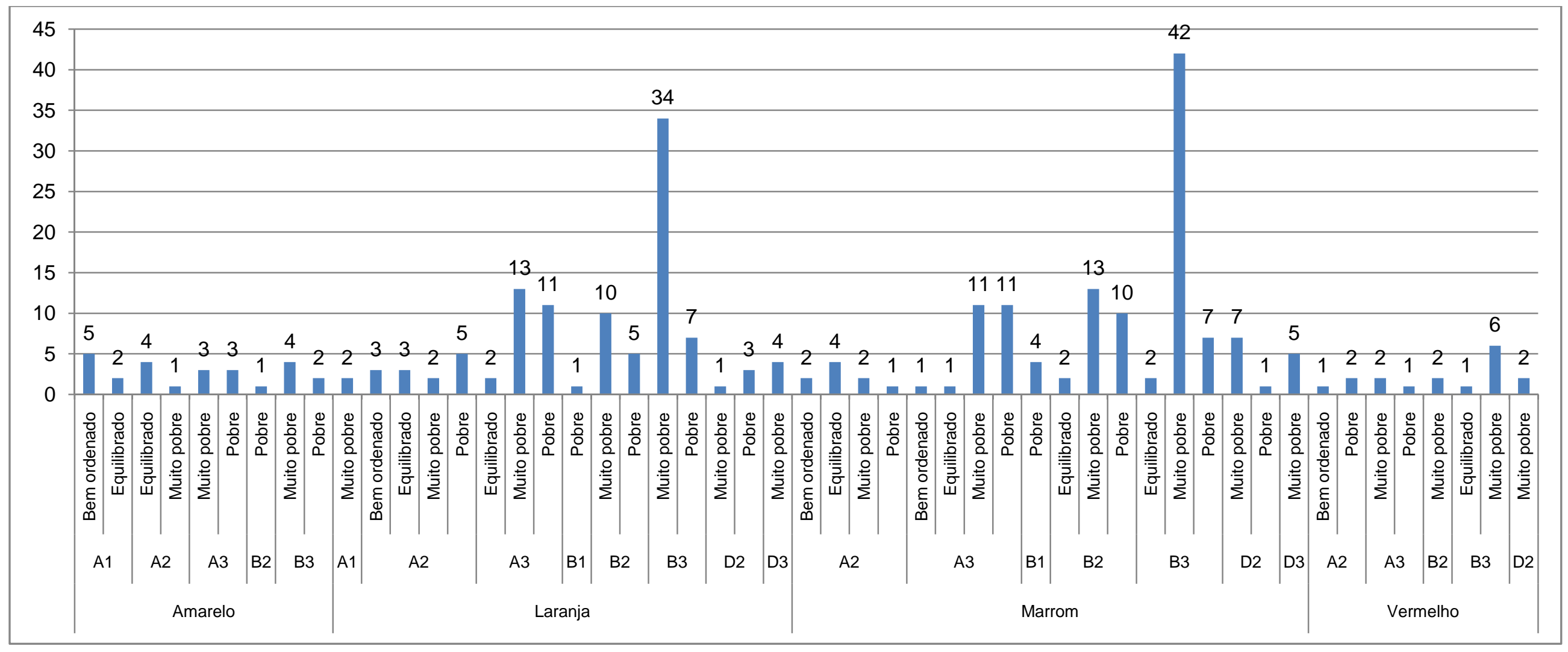

Malha 30X30M 


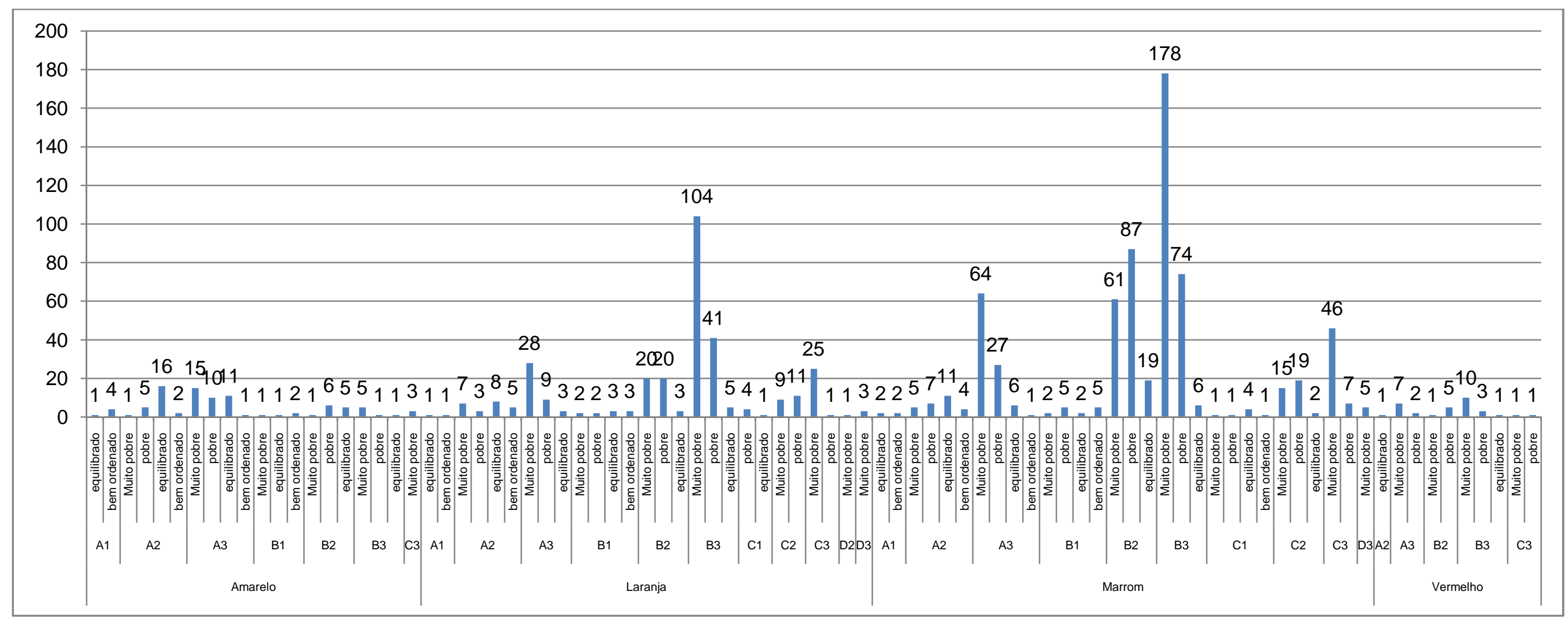

\section{Malha10X10}




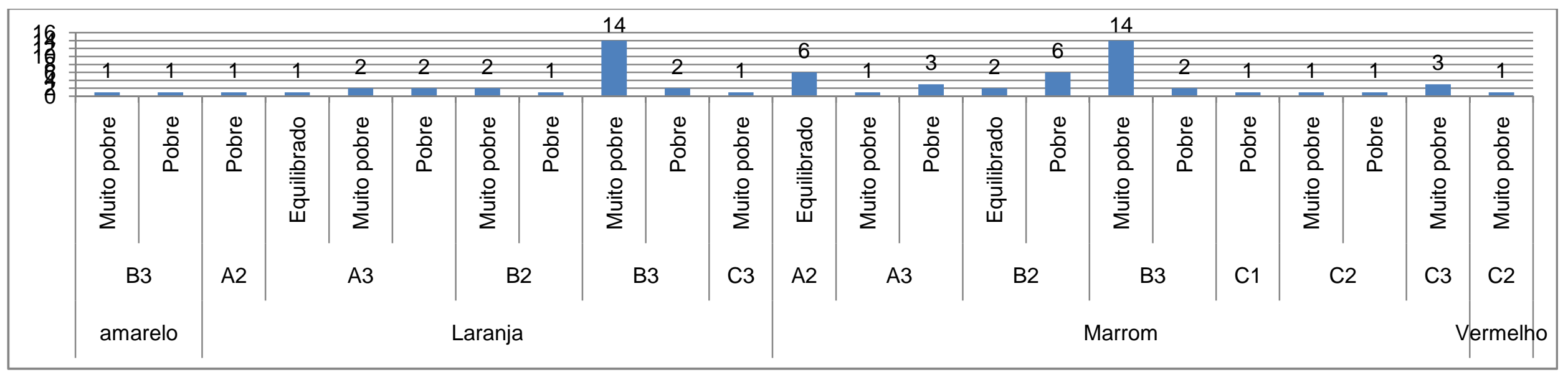

\section{Sondagem S49 E54}

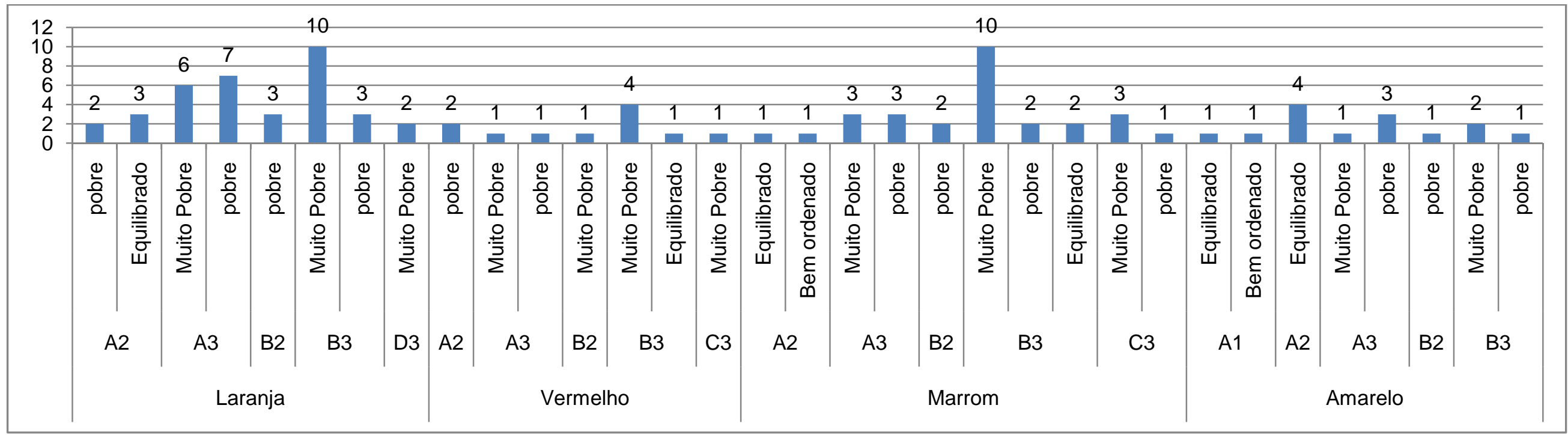

\section{Sondagem N4 E22}


Anexo 3 - distribuição vertical dos tipos de decoração plástica e pintada.

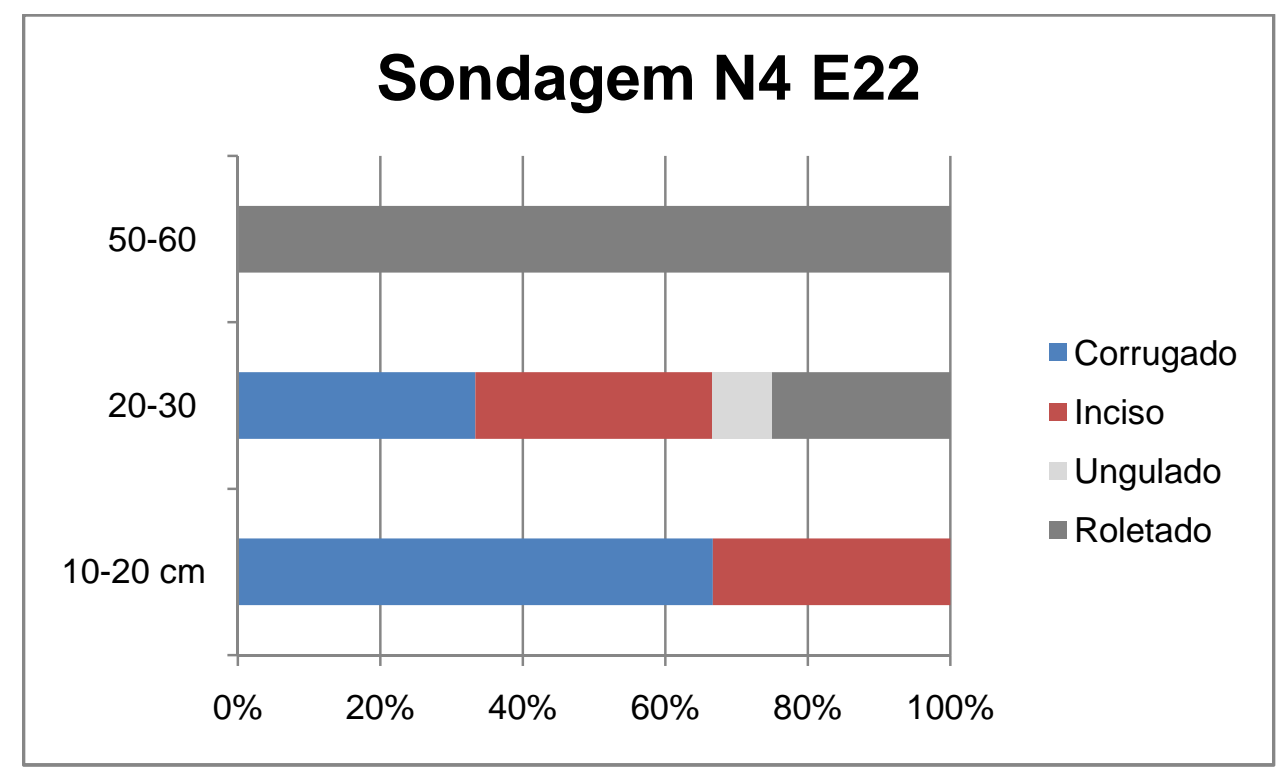

Proporção da presença de tipos decorados por nível

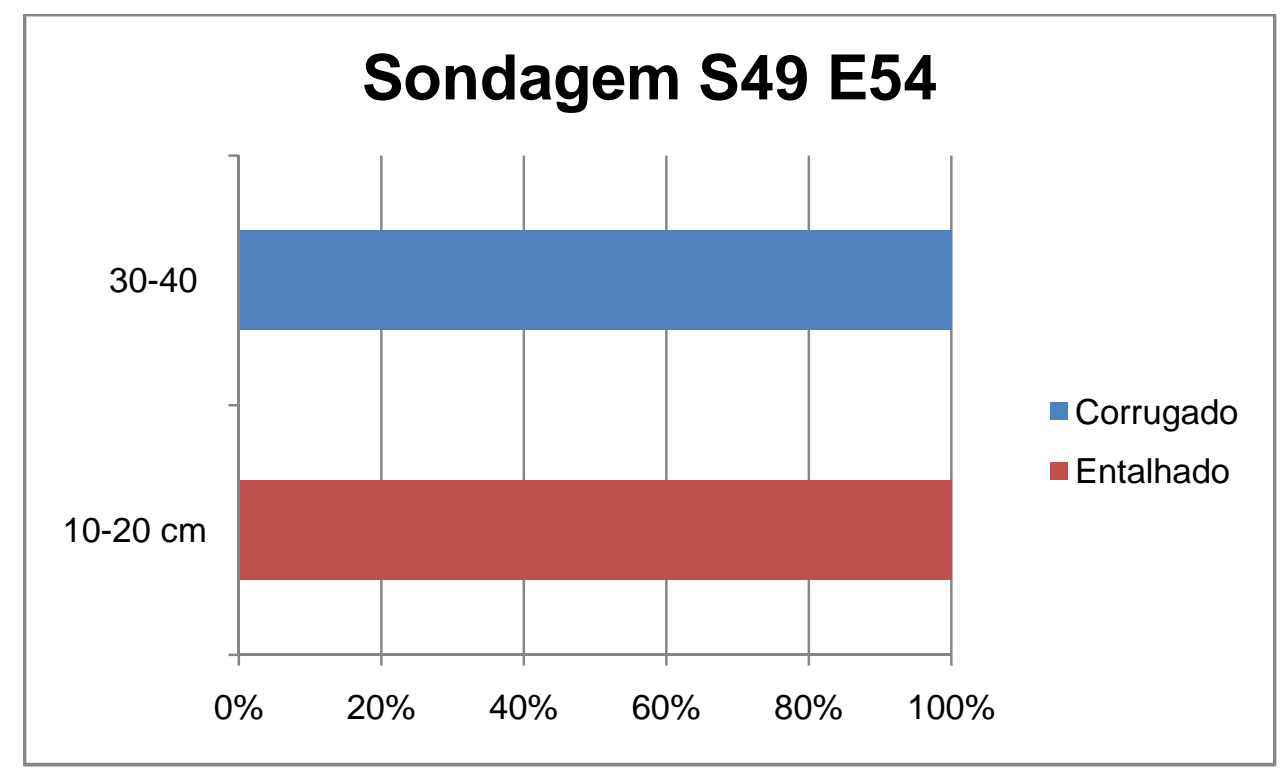

Proporção da presença de tipos decorados por nível 


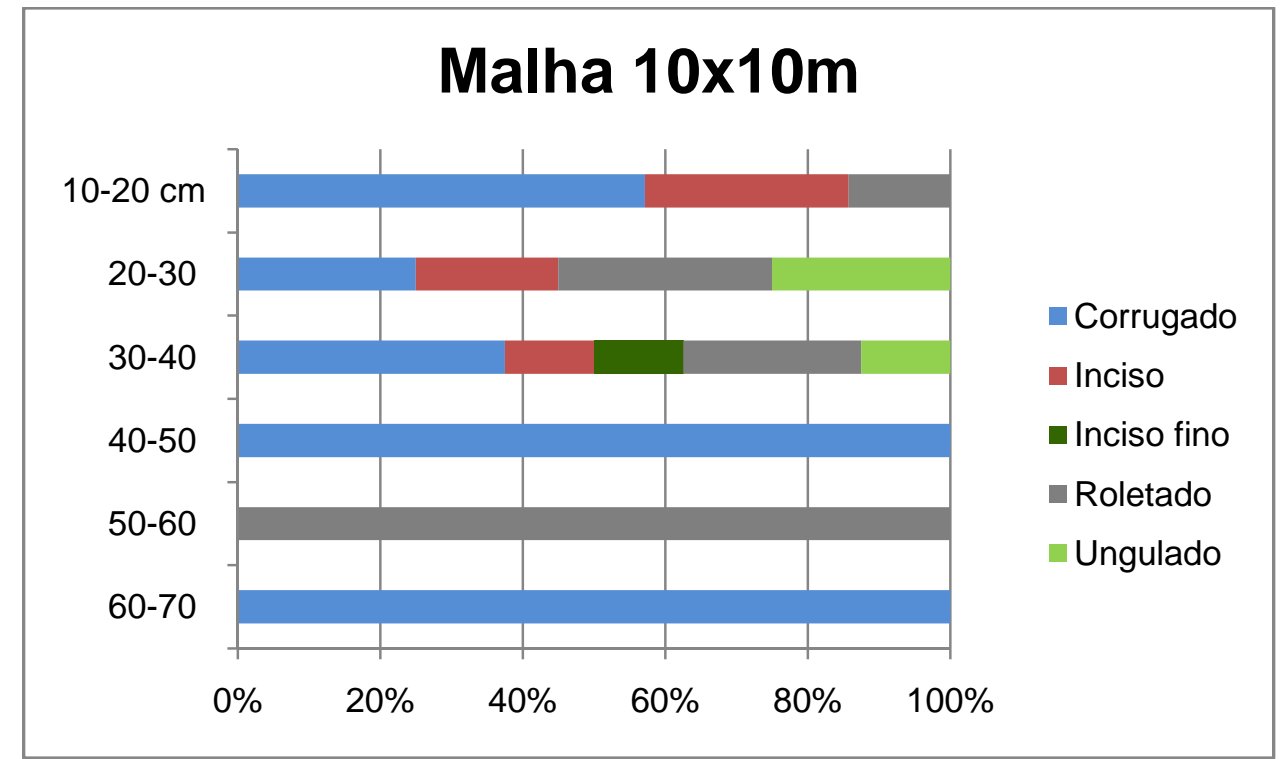

Proporção da presença de tipos decorados por nível

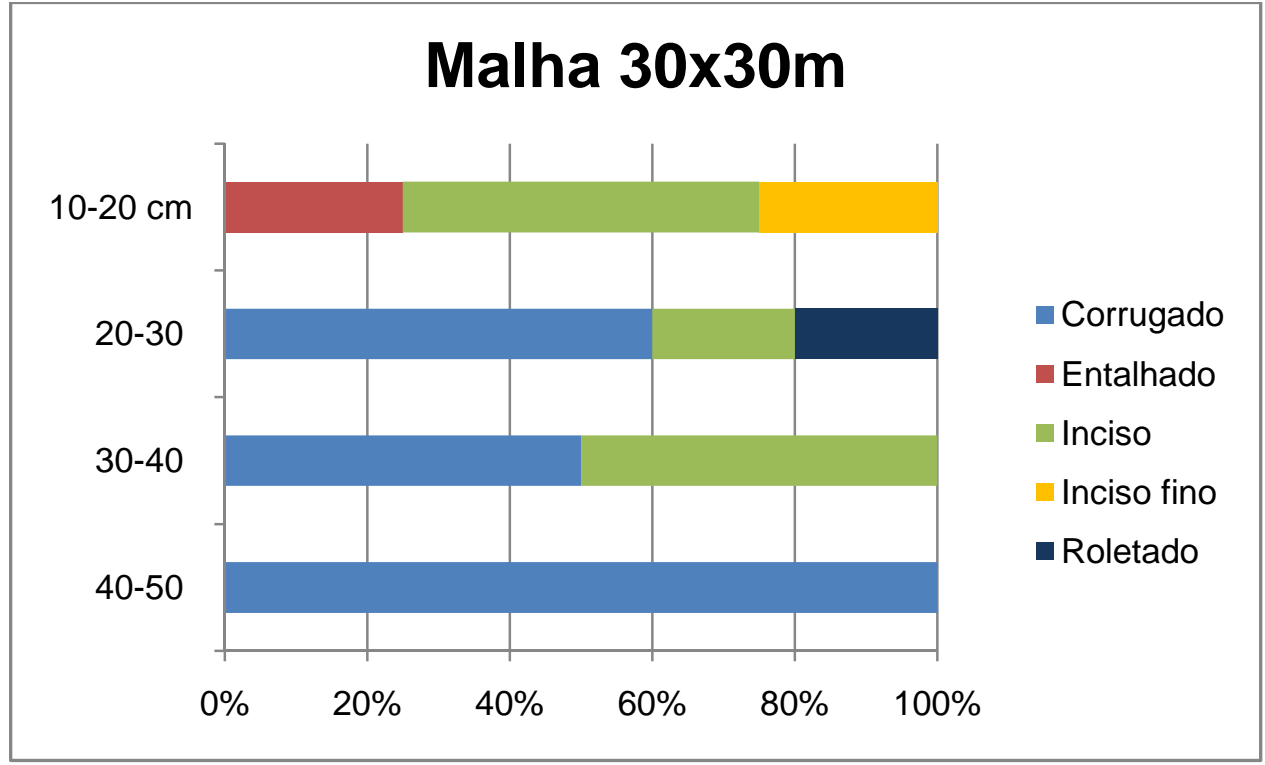

Proporção da presença de tipos decorados por nível 


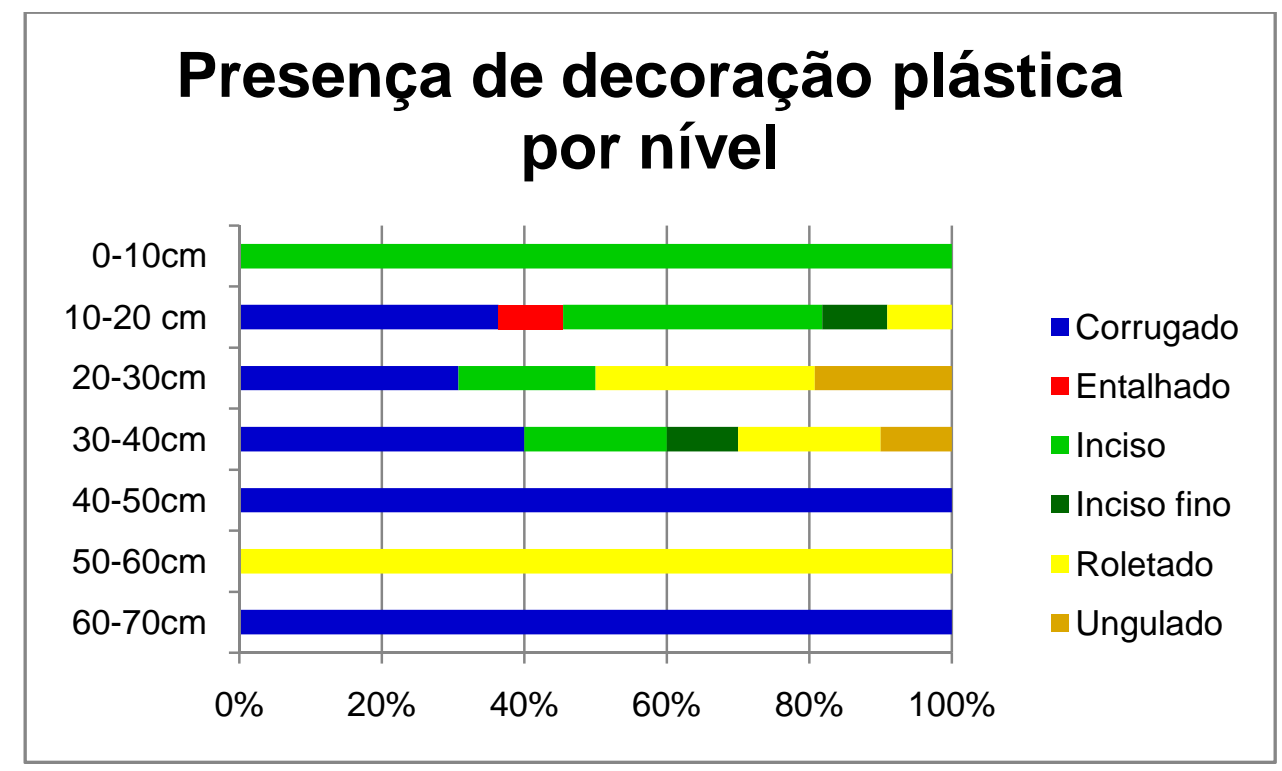

Proporção da presença de tipos decorados por nível em relacao a todo o material analisado,

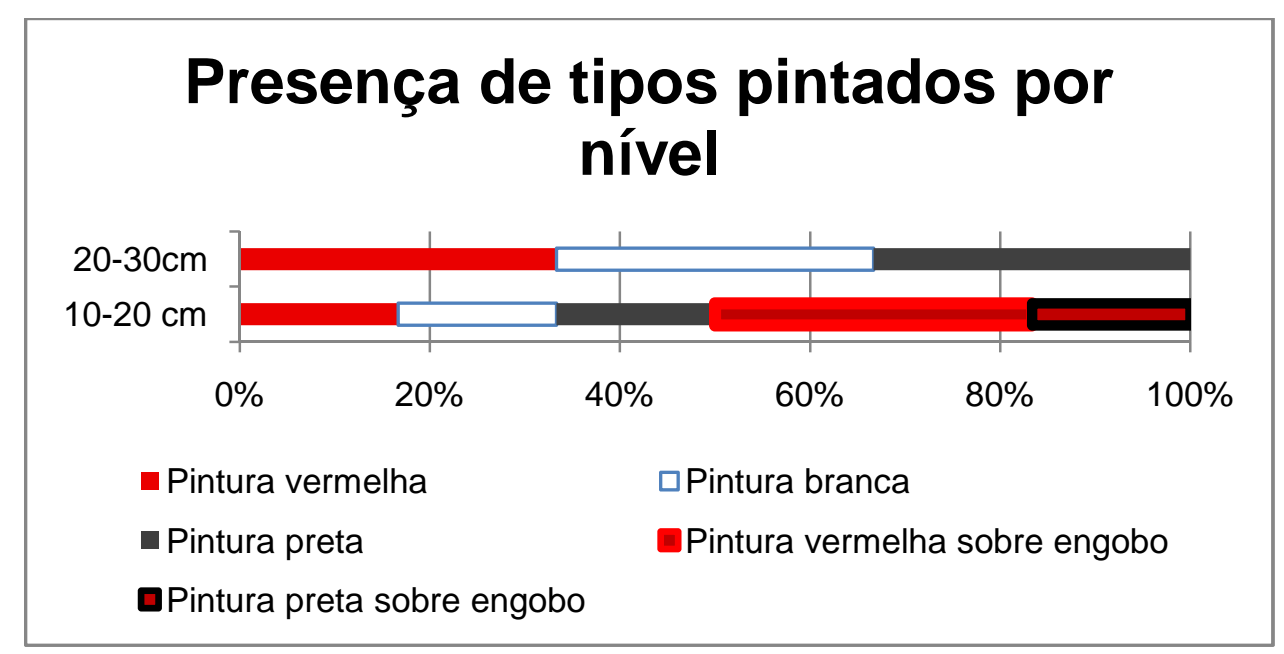

Proporção da presença de tipos pintados por nível 
ANEXO 4 - Datações em Rondônia - Calibragem a partir do aplicativo Calib 5.1 (curva intercal.14c)
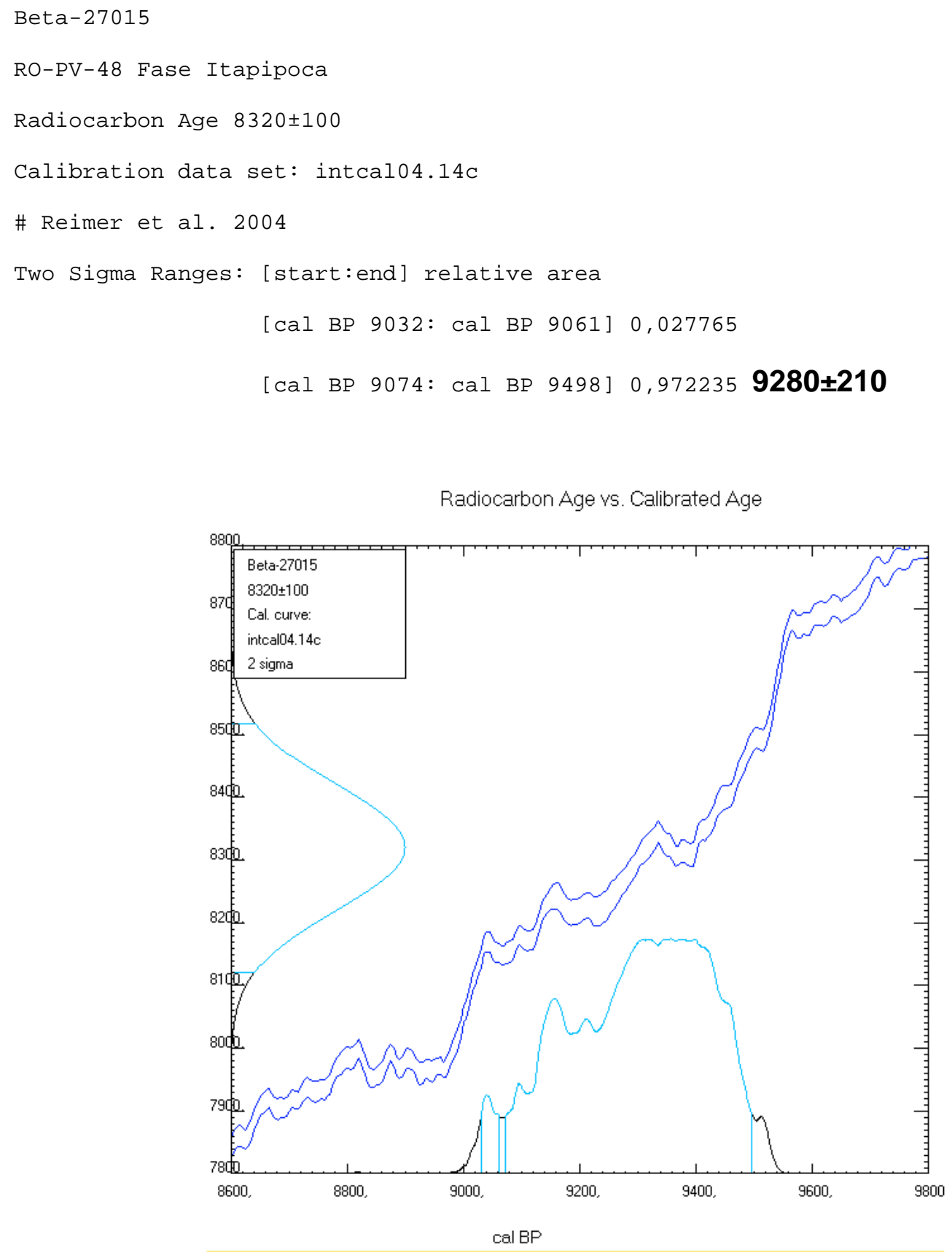
Beta-27013

RO-PV-48 Fase Itapipoca

Radiocarbon Age $6970 \pm 60$

Calibration data set: intcal04.14c

\# Reimer et al. 2004

Two Sigma Ranges: [start:end] relative area

[cal BP 7684: cal BP 7881] 0,855523 7780 $\mathbf{1 0 0}$

[cal BP 7887: cal BP 7932] 0,144477

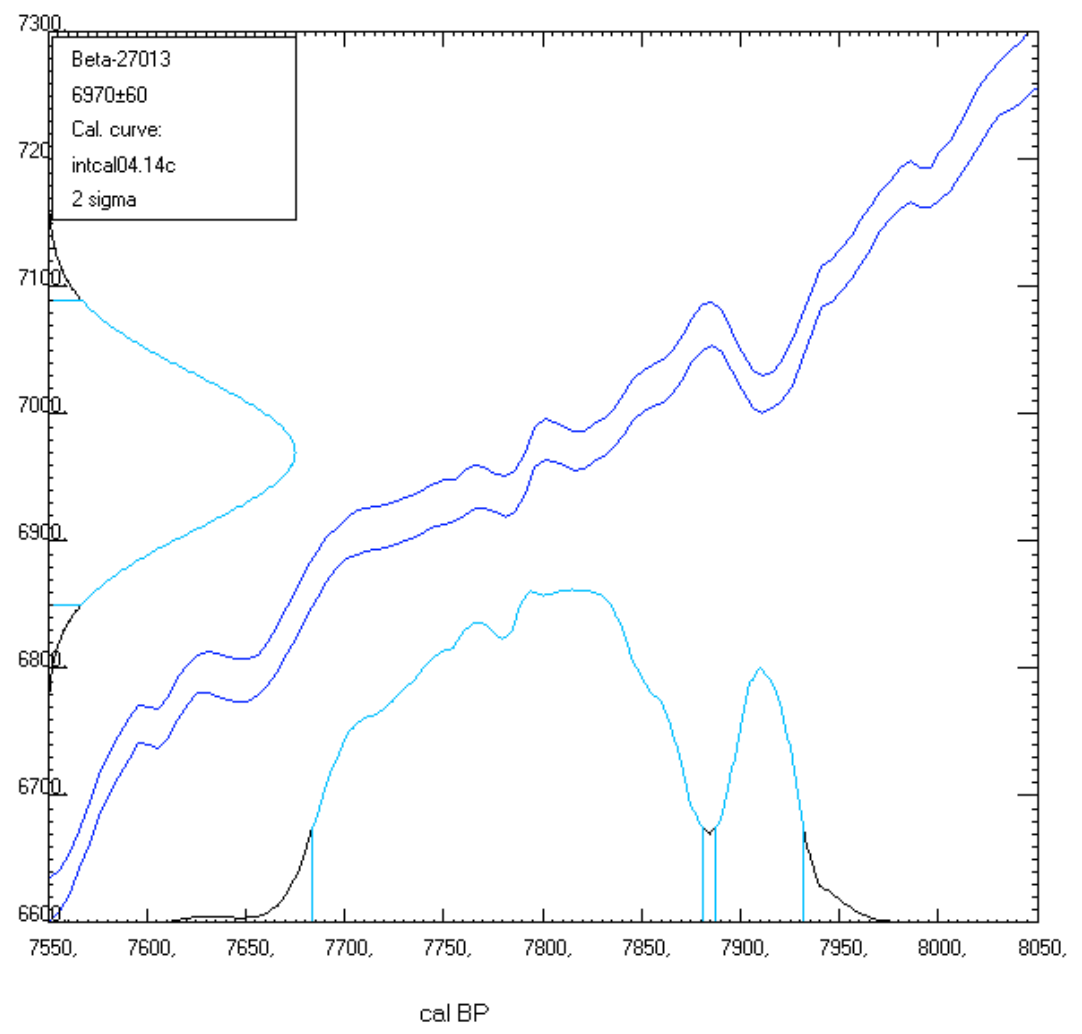


Beta-27017

RO-PV-35 Fase Pacatuba

Radiocarbon Age 5210 \pm 70

Calibration data set: intcal04.14c

\# Reimer et al. 2004

Two Sigma Ranges: [start:end] relative area

[cal BP 5755: cal BP 5824] 0,070182

[cal BP 5881: cal BP 6186] 0,929818 6035士150

Radiocarbon Age vs. Calibrated Age

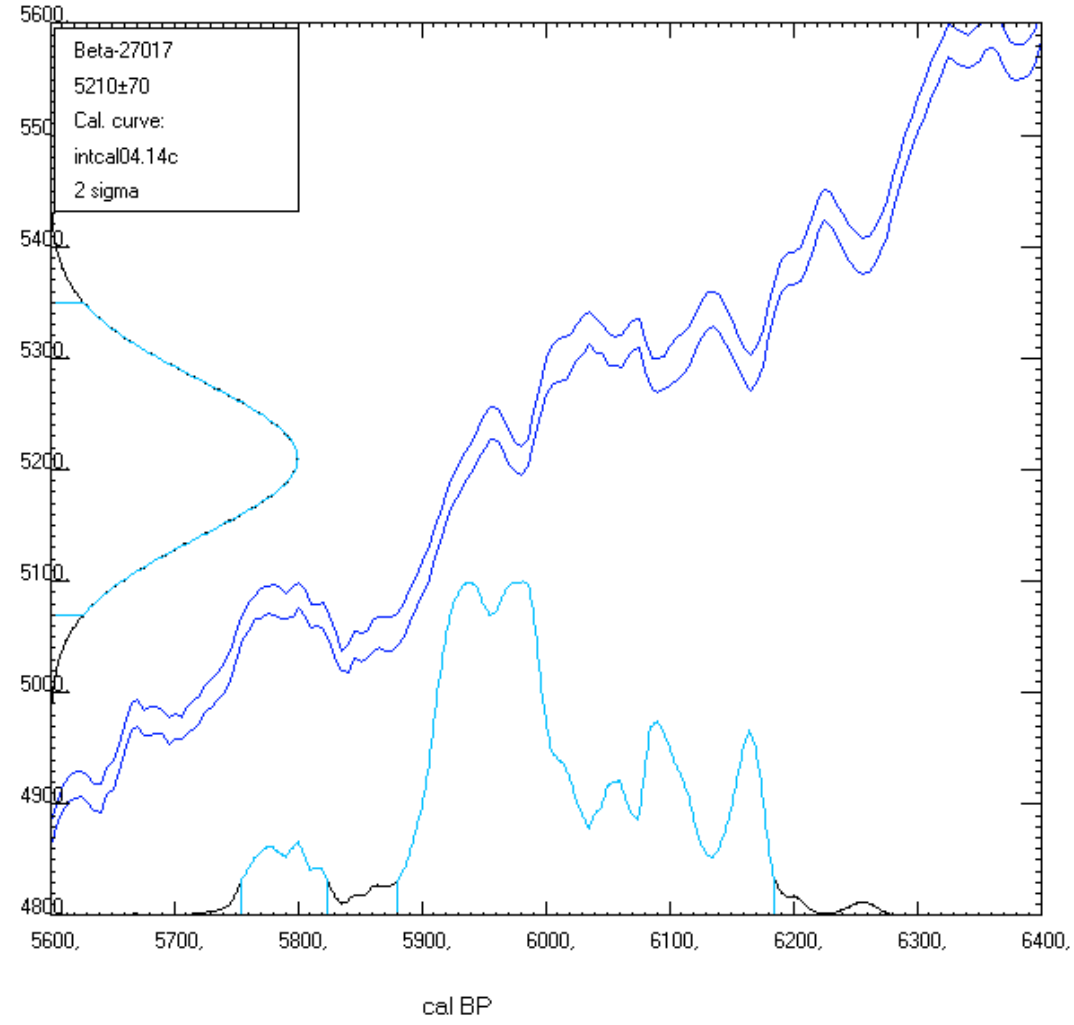


Beta-27658

RO-PV-48 Fase Pacatuba

Radiocarbon Age 6090 130

Calibration data set: intcal04.14c

\# Reimer et al. 2004

Two Sigma Ranges: [start:end] relative area

[cal BP 6663: cal BP 7265] 1, 6965 $\pm \mathbf{3 0 0}$

Radiocarbon Age vs. Calibrated Age

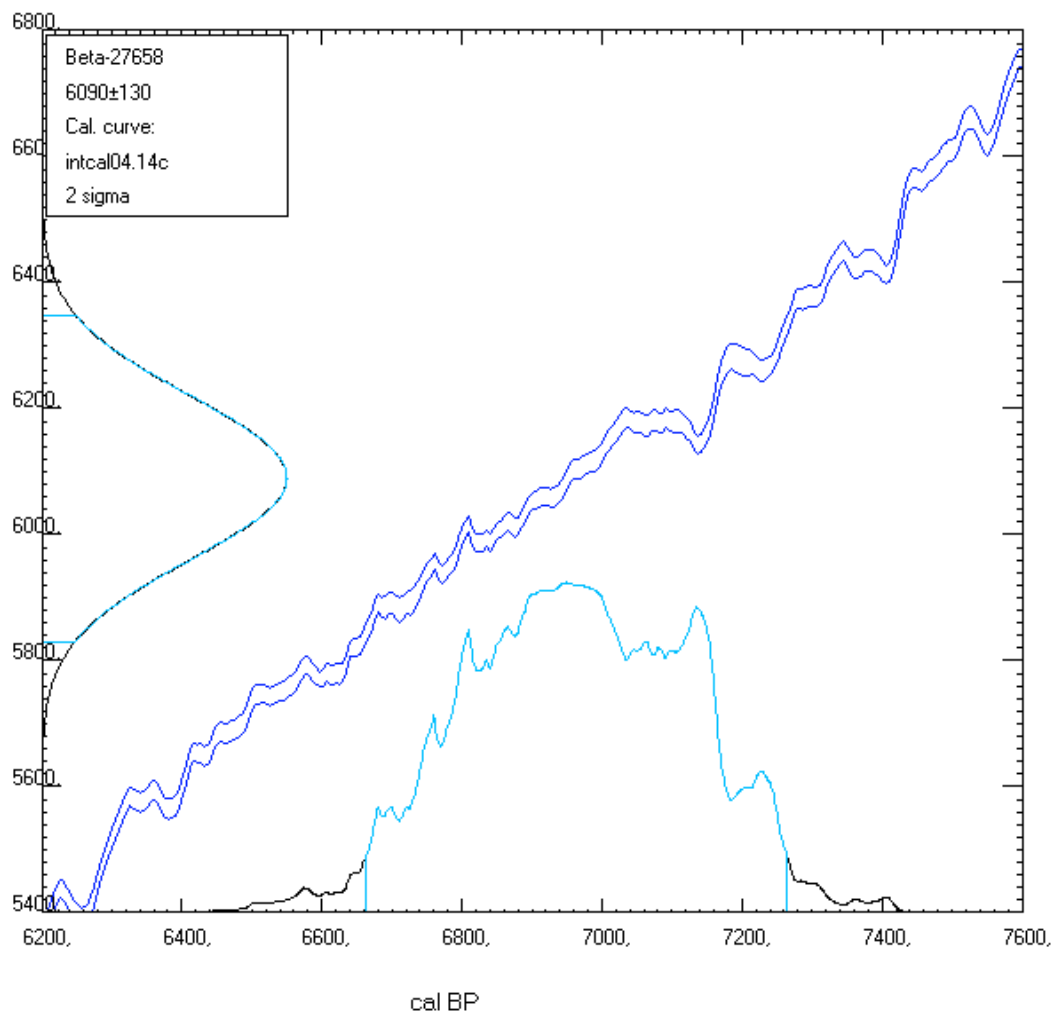


Miller et al 1992

RO-PV-48 Fase Massangana

Radiocarbon Age $4780 \pm 90$

Calibration data set: intcal04.14c

\# Reimer et al. 2004

Two Sigma Ranges: [start:end] relative area

[cal BP 5312: cal BP 5662] 0,994789 5485 $\mathbf{1 7 5}$

[cal BP 5693: cal BP 5699] 0,003671

[cal BP 5702: cal BP 5706] 0,00154

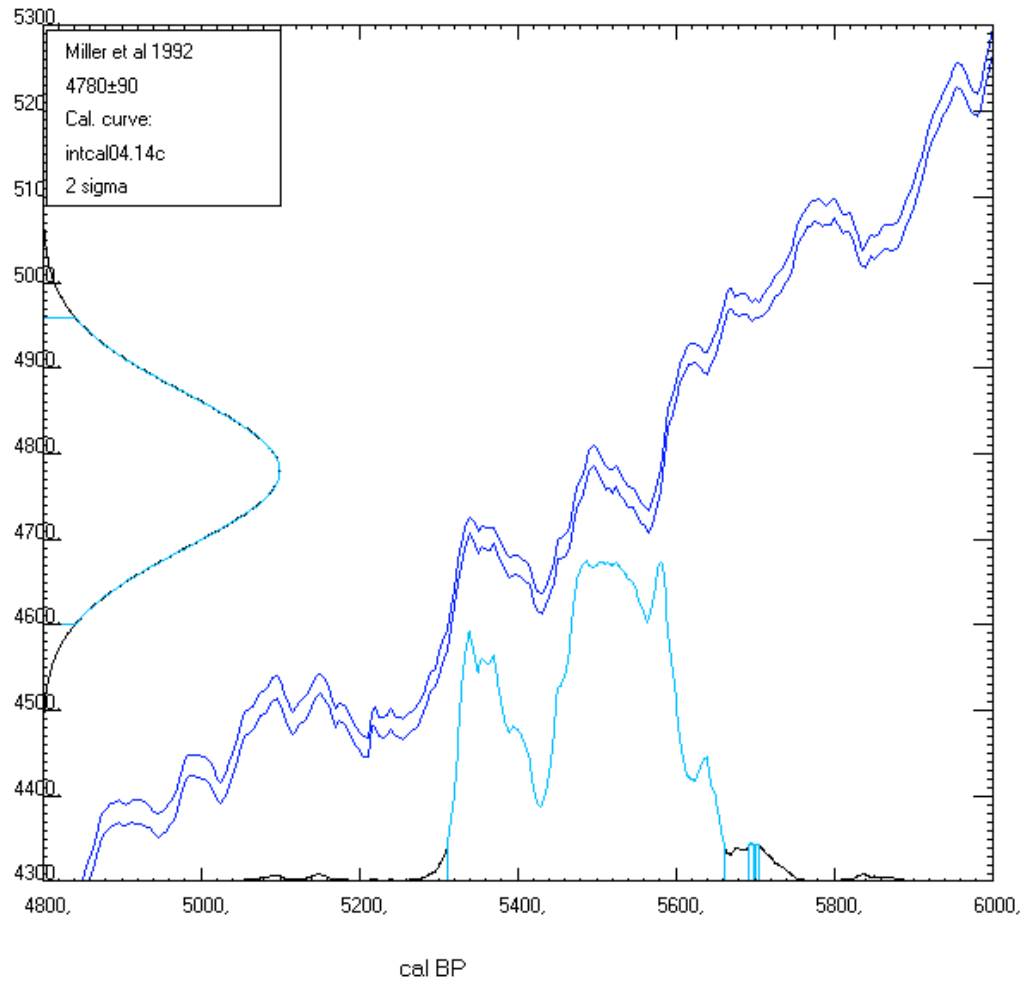


Beta-27406

RO-PV-48 Fase Massangana

Radiocarbon Age $4130 \pm 160$

Calibration data set: intcal04.14c

\# Reimer et al. 2004

Two Sigma Ranges: [start:end] relative area

[cal BP 4152: cal BP 5051] 0,995539 $\mathbf{4 6 1 0 \pm 4 4 0}$

[cal BP 5192: cal BP 5213] 0,004461

Radiocarbon Age vs. Calibrated Age

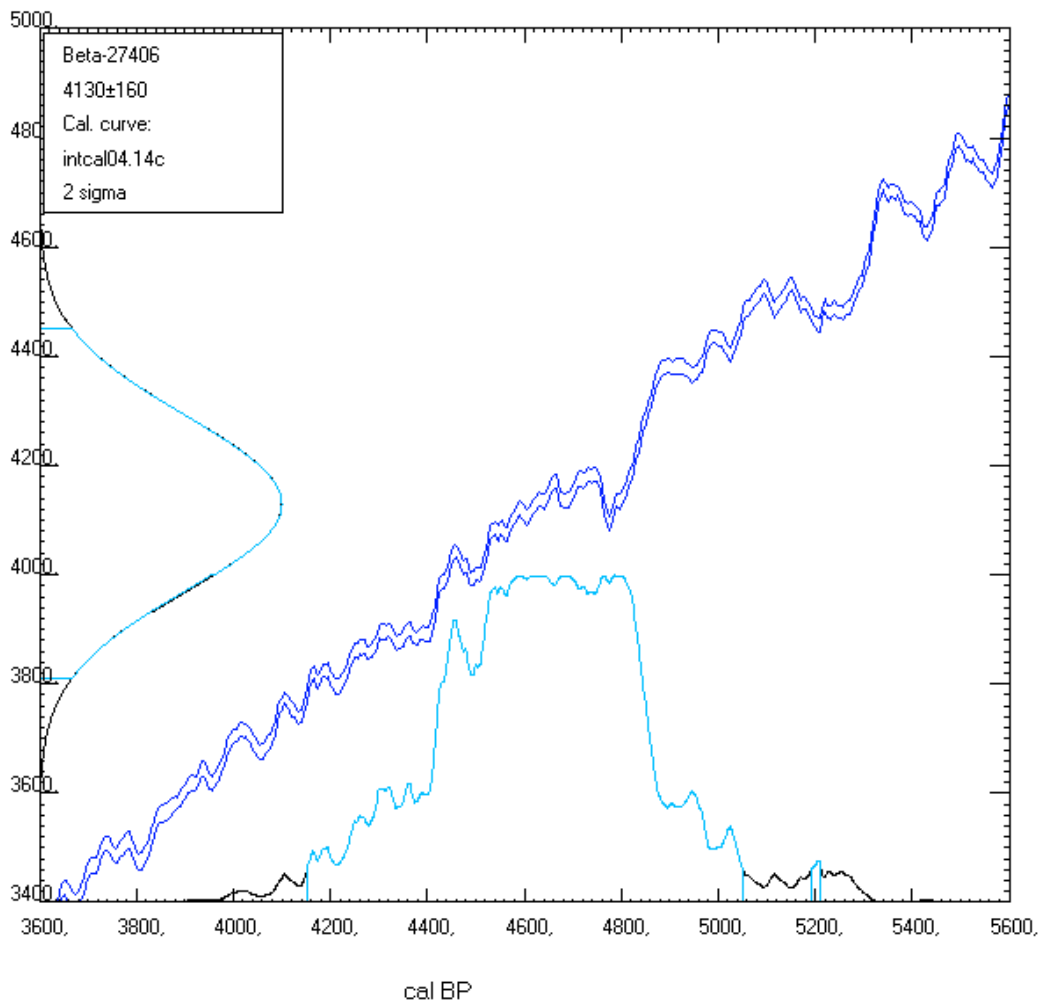


Miller et al (1992)

Fase Massangana

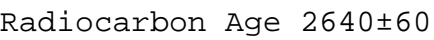

Calibration data set: intcal04.14c

\# Reimer et al. 2004

Two Sigma Ranges: [start:end] relative area

[cal BP 2503: cal BP 2532] 0,017258

[cal BP 2536: cal BP 2593] 0,046333

[cal BP 2614: cal BP 2637] 0,034381

[cal BP 2696: cal BP 2877] 0,901534 2700士180

[cal BP 2914: cal BP 2916] 0,000495

Radiocarbon Age vs. Calibrated Age

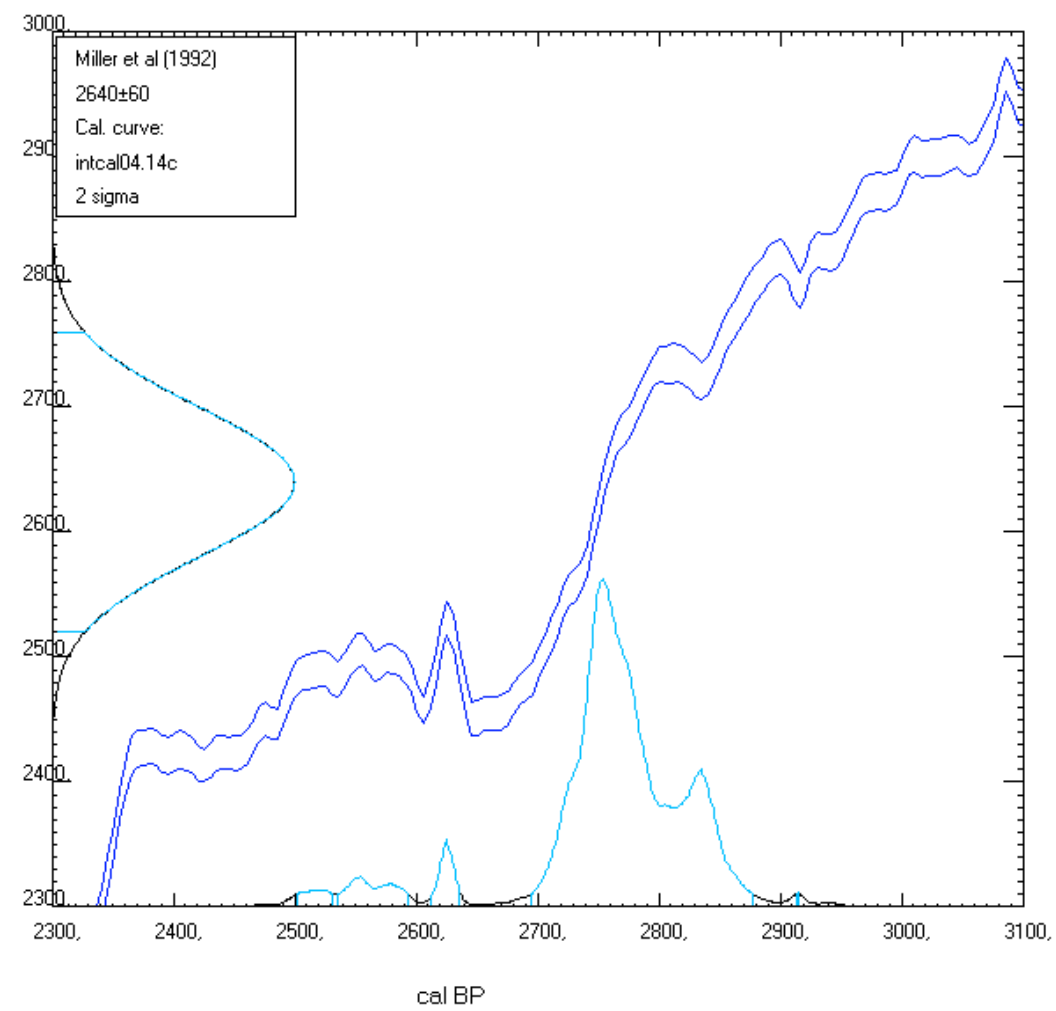


Beta-22750

Miller et al (1992) Fase Urucuri

Radiocarbon Age 2500 290

Calibration data set: intcal04.14c

\# Reimer et al. 2004

Two Sigma Ranges: [start:end] relative area

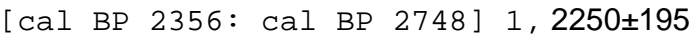

Radiocarbon Age vs. Calibrated Age

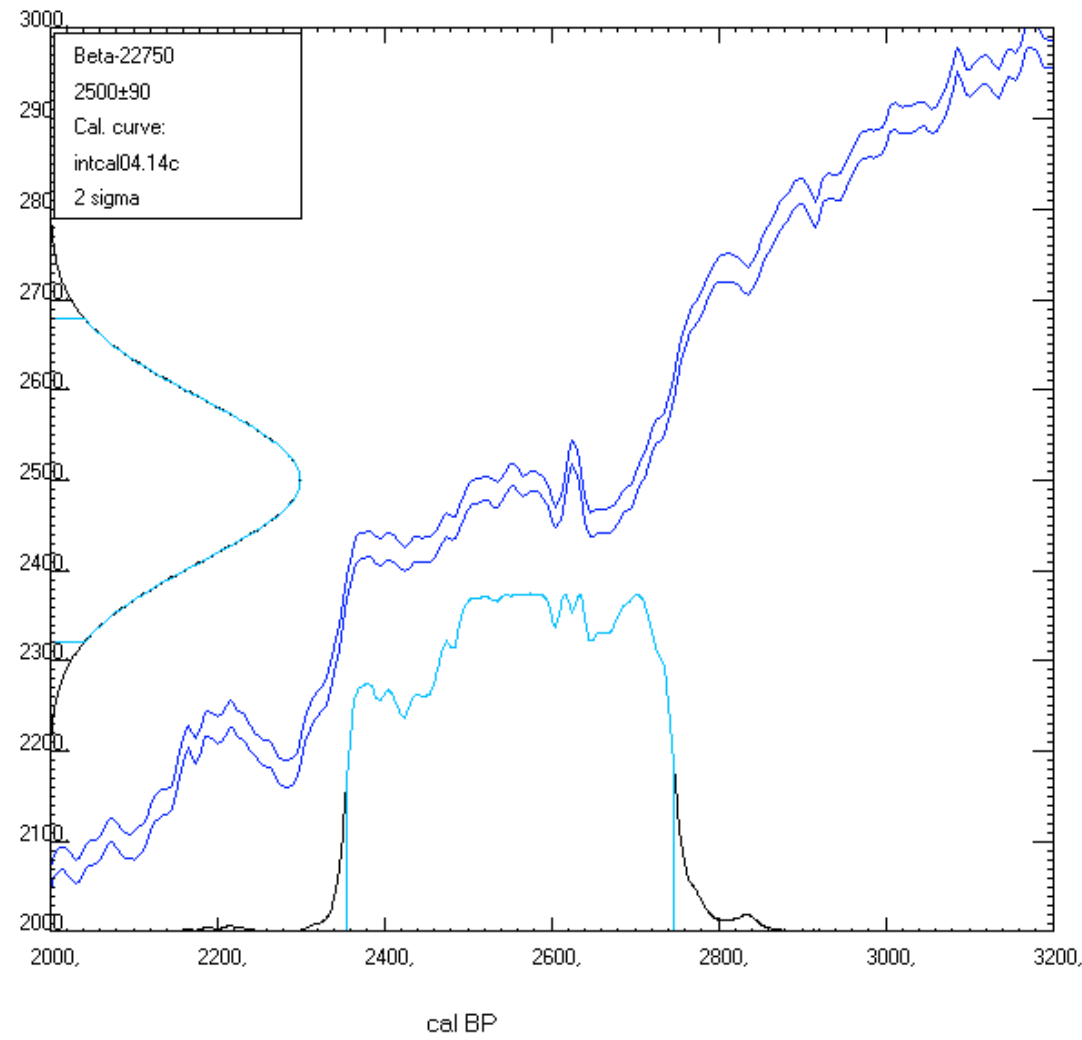


Beta 32324

Miller et al.(1992) Fase Urucuri

Radiocarbon Age 2230 50

Calibration data set: intcal04.14c

\# Reimer et al. 2004

Two Sigma Ranges: [start:end] relative area

[cal BP 2135: cal BP 2343] 1, 2240 $\mathbf{1 0 5}$

Radiocarbon Age vs. Calibrated Age

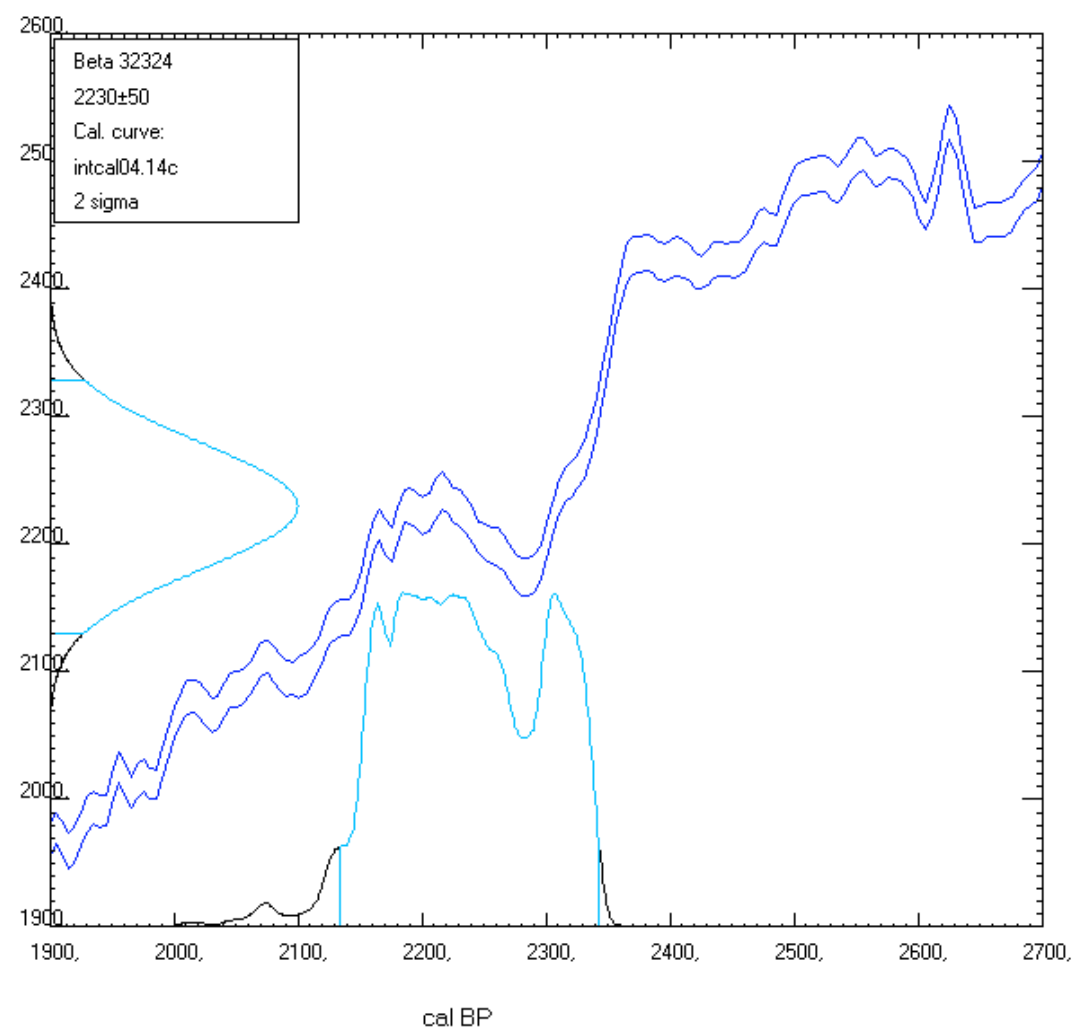


Beta-22757

Miller et al.(1992) Fase Urucuri

Radiocarbon Age 2410 250

Calibration data set: intcal04.14c

\# Reimer et al. 2004

Two Sigma Ranges: [start:end] relative area

[cal BP 2344: cal BP 2546] 0,728215 2445 $\$ 100$

[cal BP 2560: cal BP 2575] 0,018278

[cal BP 2579: cal BP 2617] 0,071978

[cal BP 2634: cal BP 2702] 0,181529

Radiocarbon Age vs. Calibrated Age

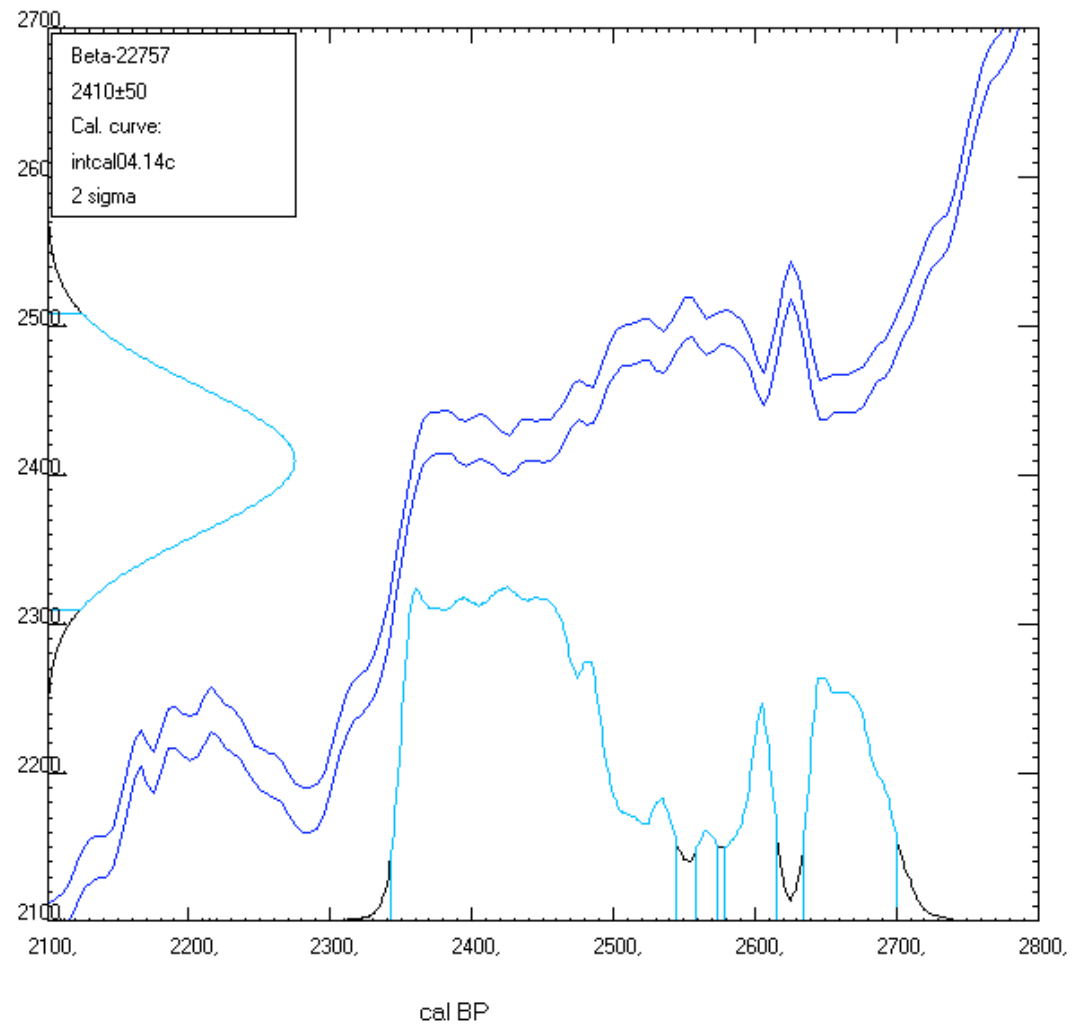


Beta-22744

Miller et al (1992) Fase Urucuri

Radiocarbon Age $2280 \pm 100$

Calibration data set: intcal04.14c

\# Reimer et al. 2004

Two Sigma Ranges: [start:end] relative area

[cal BP 2004: cal BP 2028] 0,01187

[cal BP 2036: cal BP 2519] 0,920865 2280 $\mathbf{2 4 0}$

[cal BP 2525: cal BP 2541] 0,007039

[cal BP 2591: cal BP 2615] 0,015003

[cal BP 2636: cal BP 2698] 0,045223

Radiocarbon Age vs. Calibrated Age

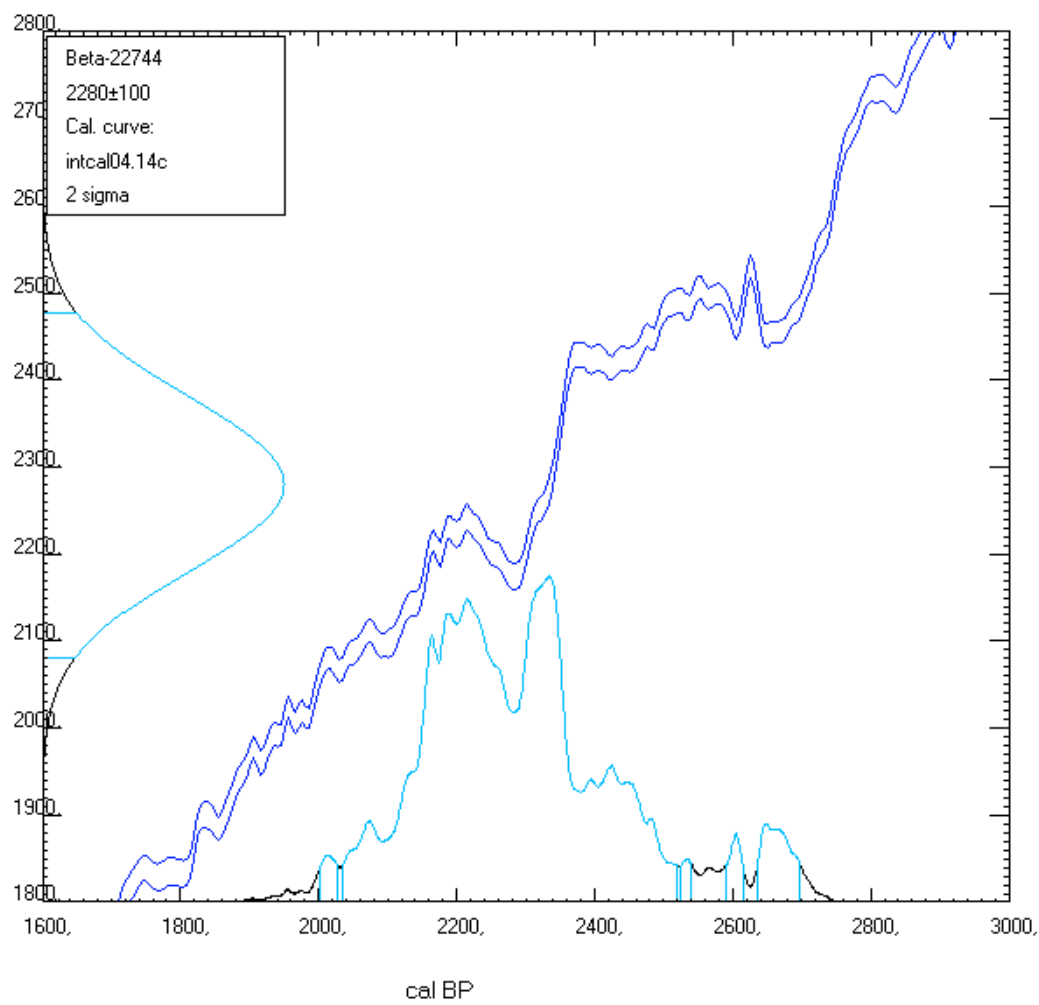


Beta-22764

Miller et al (1992) Fase Jamari

Radiocarbon Age 2130 \pm 140

Calibration data set: intcal04.14c

\# Reimer et al. 2004

Two Sigma Ranges: [start:end] relative area

[cal BP 1738: cal BP 1759] 0,005741

[cal BP 1774: cal BP 2376] 0,97295 2075 $\mathbf{3 0 0}$

[cal BP 2384: cal BP 2459] 0,021308

Radiocarbon Age vs. Calibrated Age

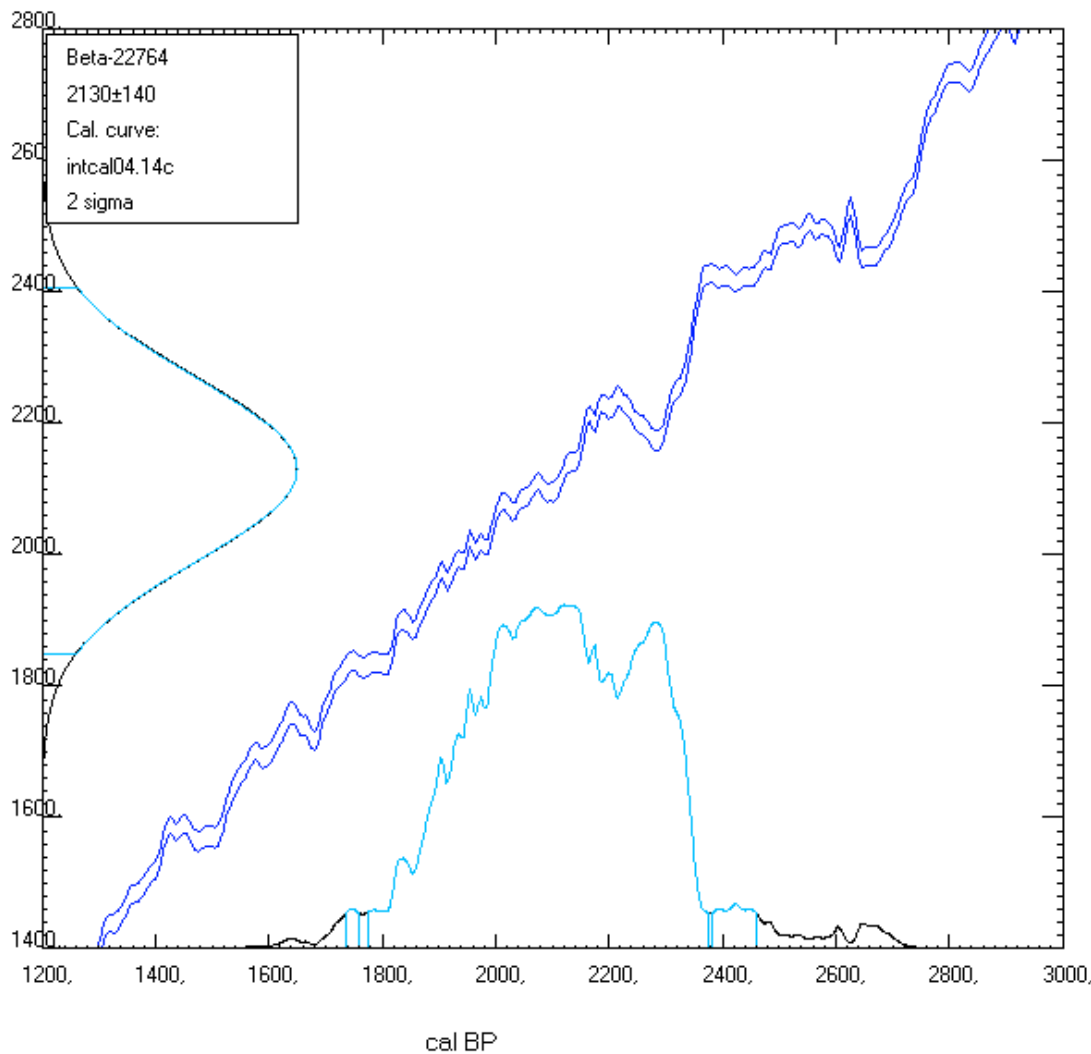


Beta-22751

iller et al (1992) Fase Jamari/Matapi

Radiocarbon Age $420 \pm 50$

Calibration data set: intcal04.14c

\# Reimer et al. 2004

Two Sigma Ranges: [start:end] relative area

[cal BP 317: cal BP 396] 0,262207

[cal BP 423: cal BP 535] 0,737793 $480 \mathbf{5 5 5}$

Radiocarbon Age vs. Calibrated Age

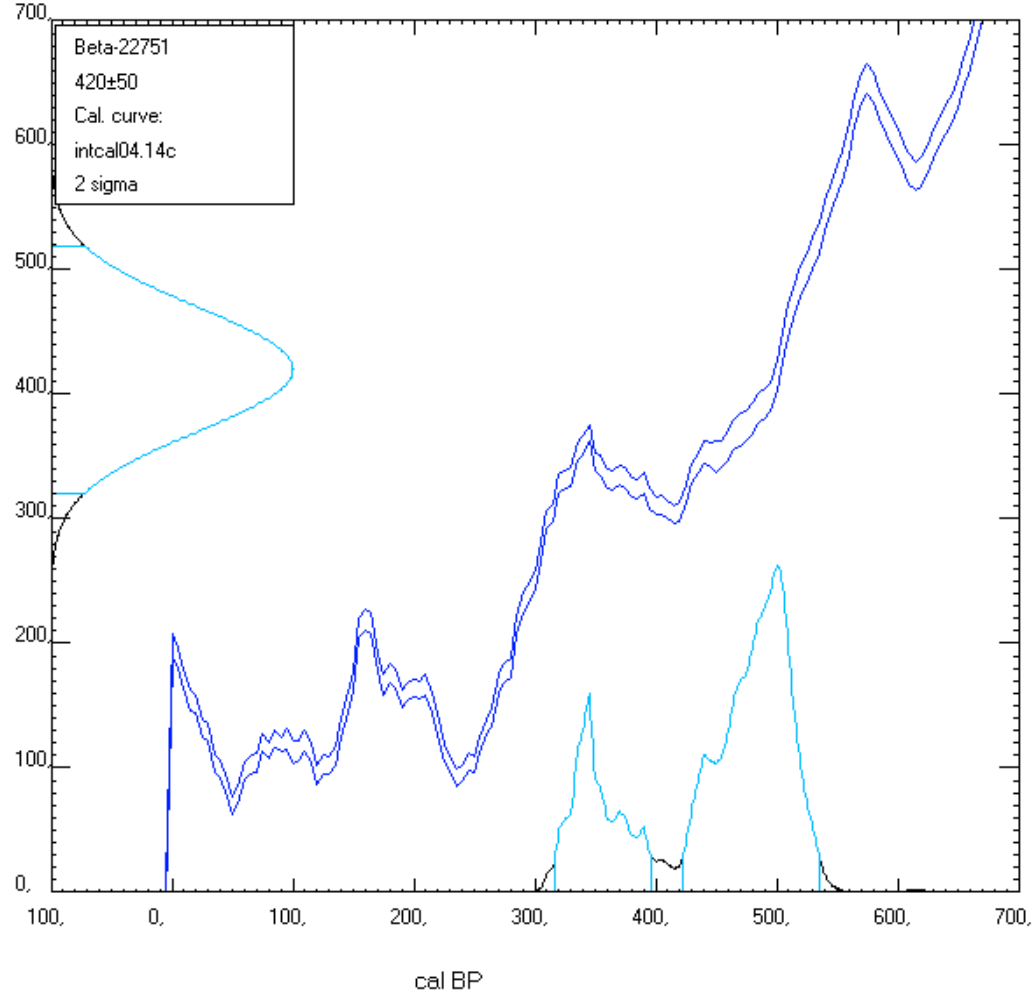


Beta -51729

Miller et al (1992) Fase Cupui

Radiocarbon Age $1350 \pm 60$

Calibration data set: intcal04.14c

\# Reimer et al. 2004

Two Sigma Ranges: [start:end] relative area

[cal BP 1141: cal BP 1160] 0,015132

[cal BP 1168: cal BP 1381] 0,984868 1275士105

Radiocarbon Age vs. Calibrated Age

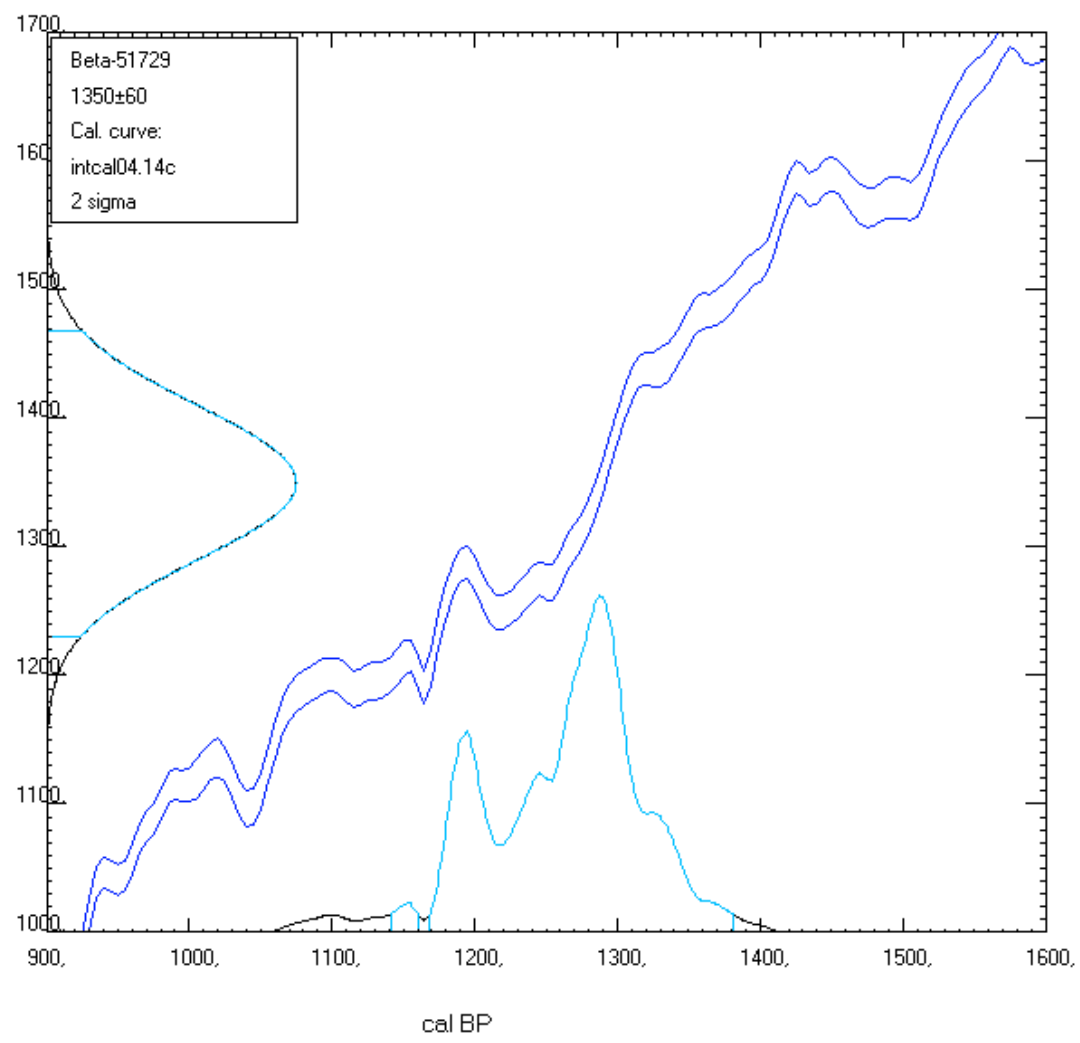


Beta-22752

Miller et al (1992) Fase Matapi

Radiocarbon Age $230 \pm 80$

Calibration data set: intcal04.14c

\# Reimer et al. 2004

Two Sigma Ranges: [start:end] relative area

[*Cal BP -3: cal BP 42] 0,107967

[cal BP 59: cal BP 234] 0,394603

[cal BP 238: cal BP 464] 0,49743 355 $\mathbf{1 1 0}$

Radiocarbon Age vs. Calibrated Age

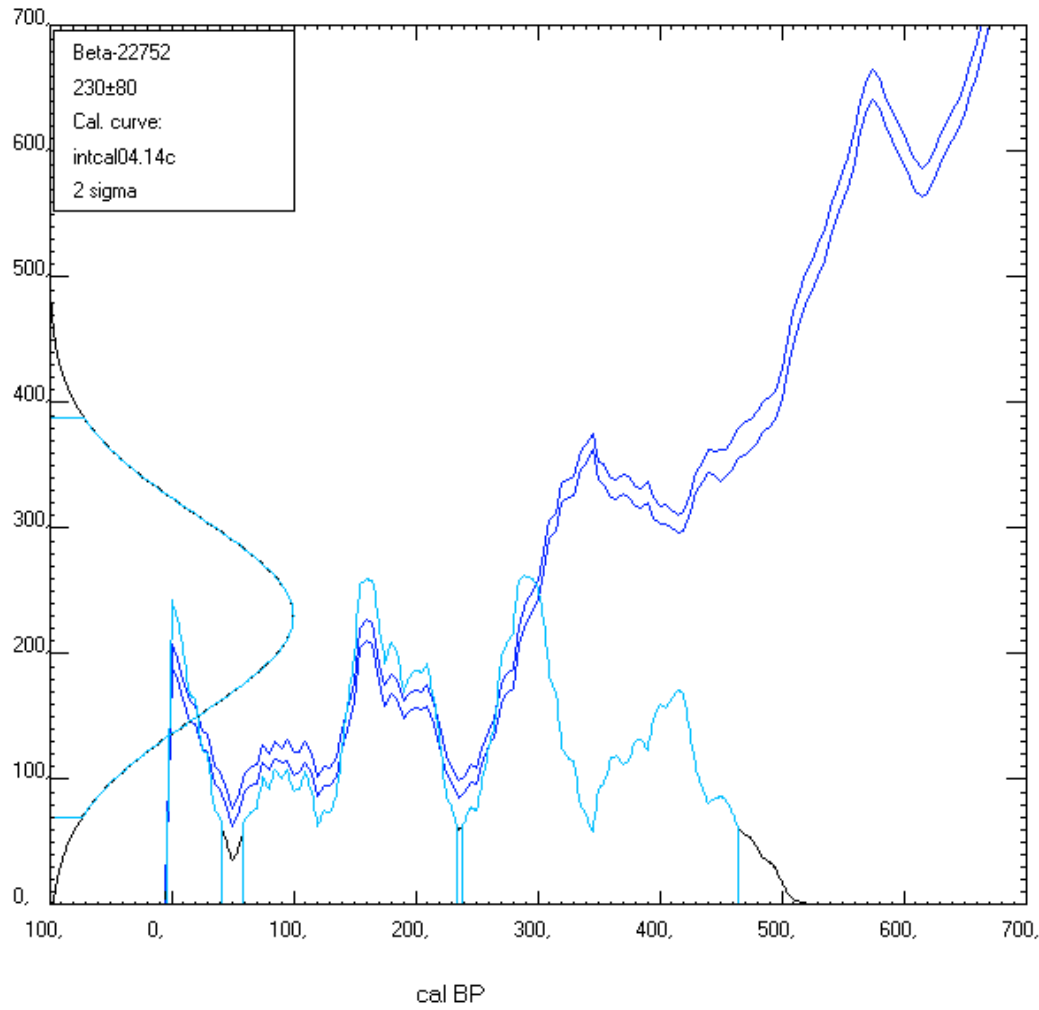


SI-3950

RO-JP-01 Subtradicao Jatuarana

Radiocarbon Age $2730 \pm 75$

Calibration data set: intcal04.14c

\# Reimer et al. 2004

Two Sigma Ranges: [start:end] relative area

[cal BP 2733: cal BP 3005] 0,99087 2870 $\mathbf{1 3 5}$

[cal BP 3014: cal BP 3025] 0,005581

[cal BP 3052: cal BP 3059] 0,003549

Radiocarbon Age vs. Calibrated Age

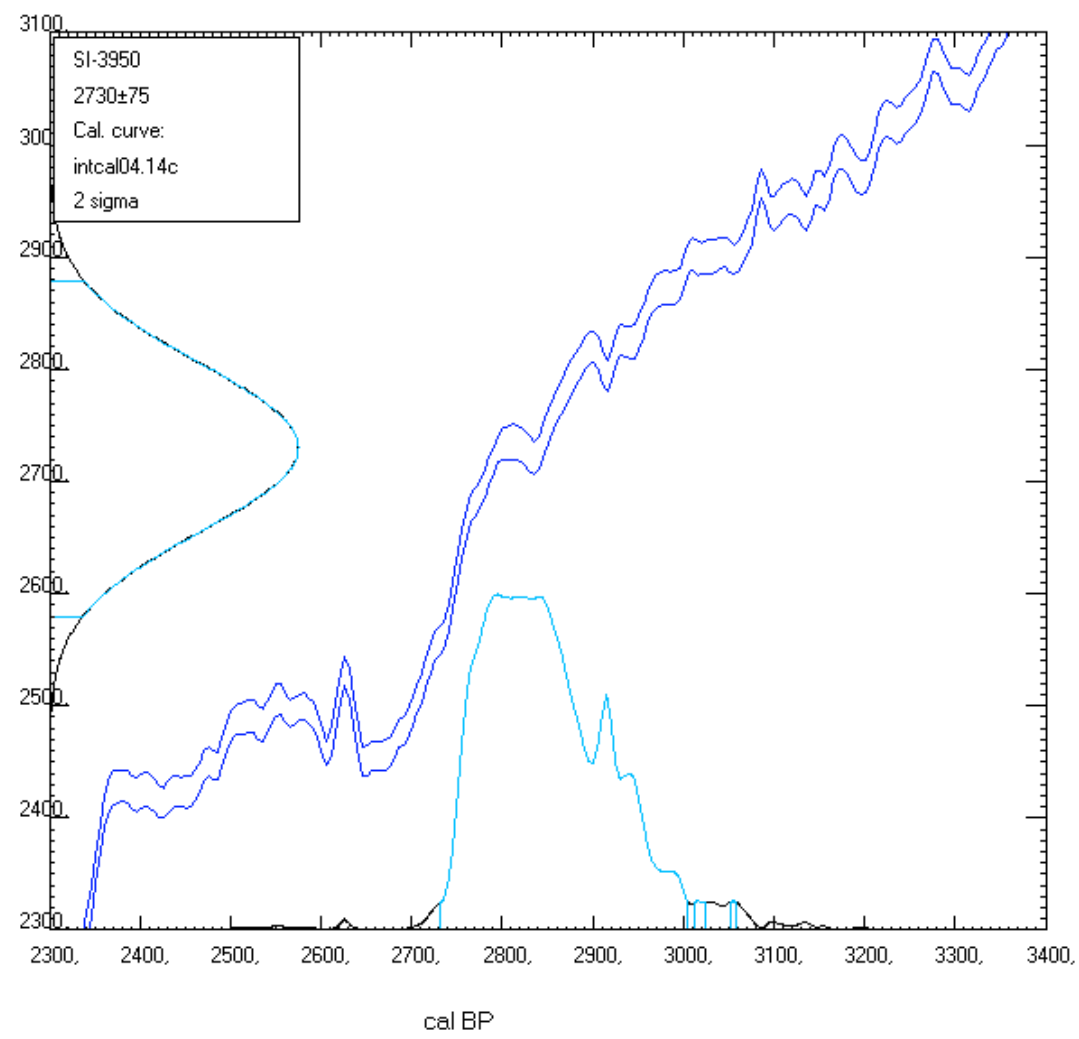


Beta-33456

RO-PV-19 Subtradicao Jatuarana

Radiocarbon Age 2340土90

Calibration data set: intcal04.14c

\# Reimer et al. 2004

Two Sigma Ranges: [start:end] relative area

[cal BP 2152: cal BP 2618] 0,887469 2385 $\mathbf{2 3 3 0}$

[cal BP 2633: cal BP 2705] 0,112531

Radiocarbon Age vs. Calibrated Age

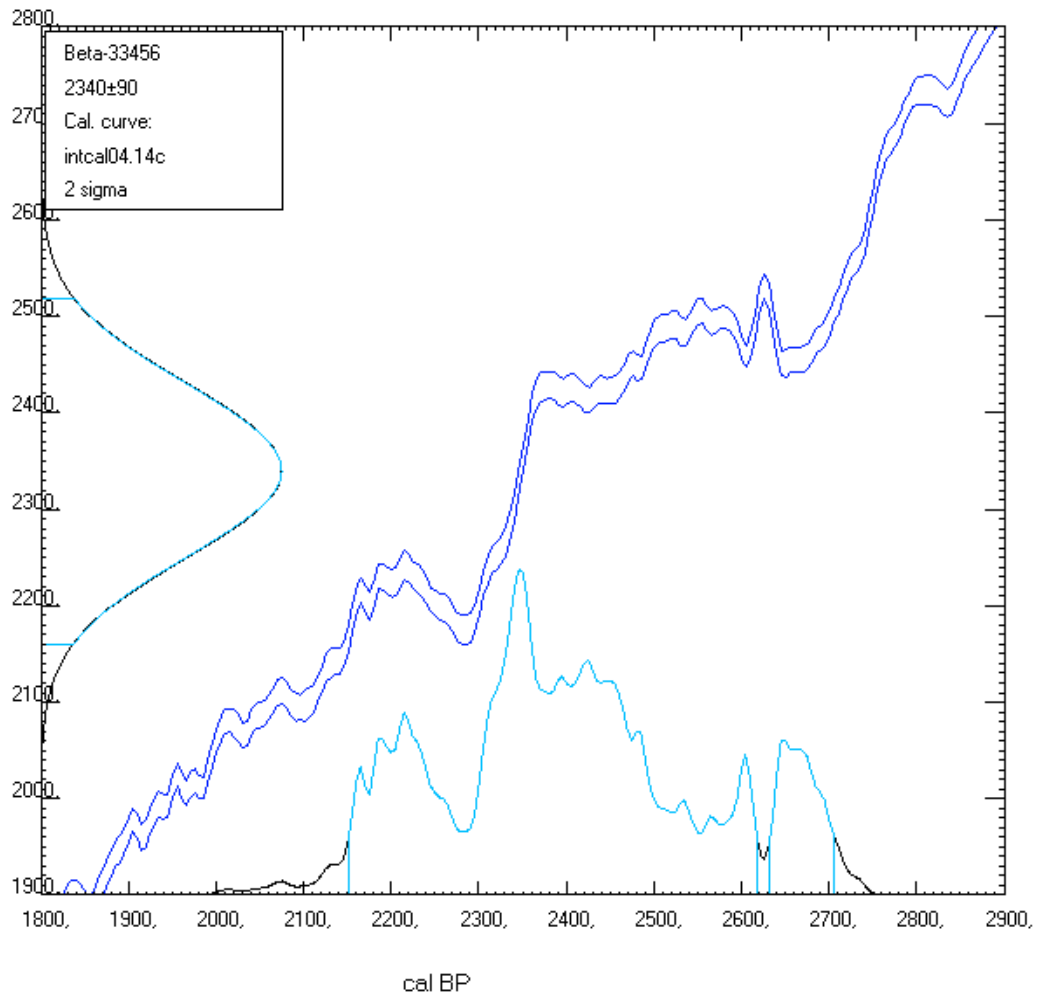


$S I-6850$

RO-PN-08 Sinimbu

Radiocarbon Age $6315 \pm 105$

Calibration data set: intcal04.14c

\# Reimer et al. 2004

Two Sigma Ranges: [start:end] relative area

[cal BP 6975: cal BP 7429] 1, 7200 225

Radiocarbon Age vs. Calibrated Age

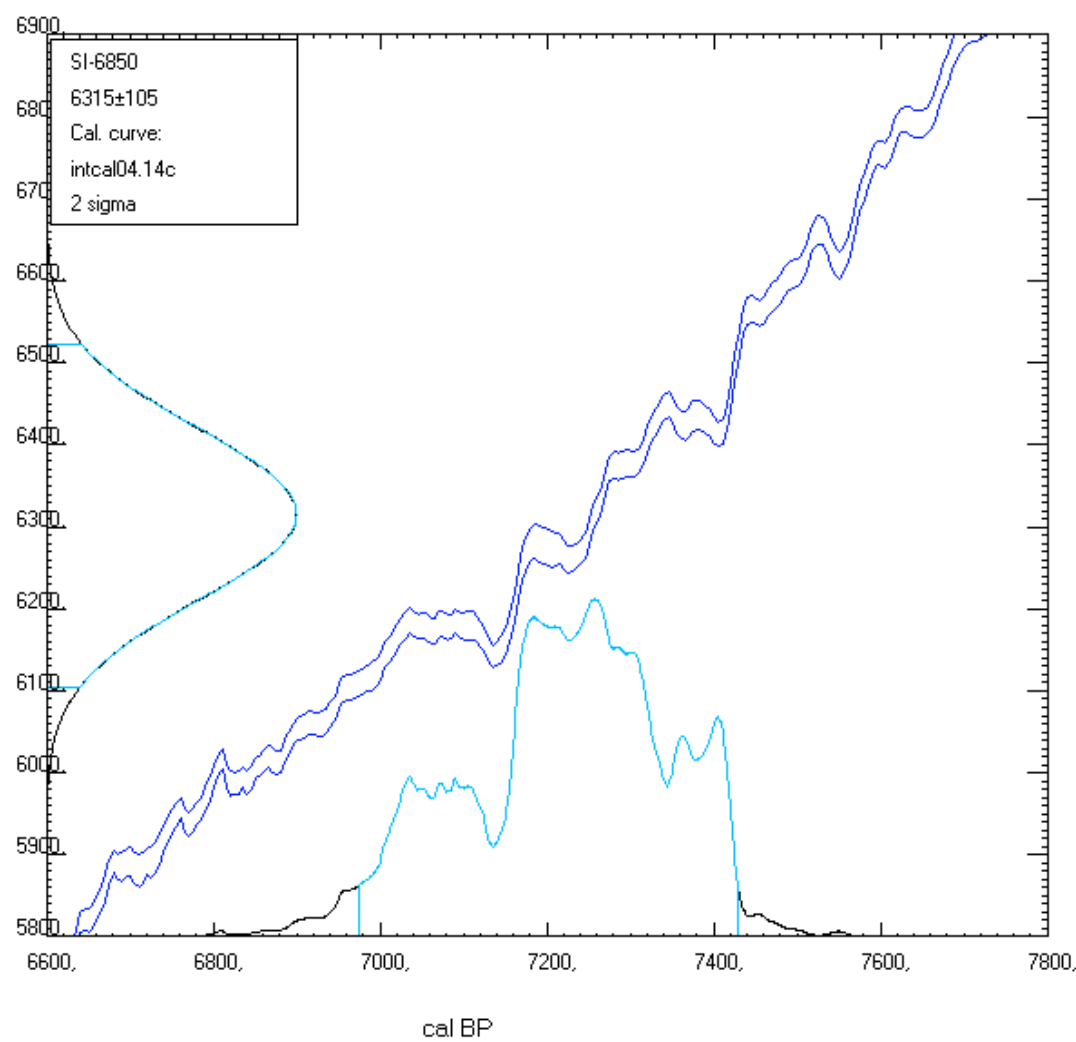


SI -6847

RO-PN-08 Fase Bacabal

Radiocarbon Age $3920 \pm 85$

Calibration data set: intcal04.14c

\# Reimer et al. 2004

Two Sigma Ranges: [start:end] relative area

[cal BP 4089: cal BP 4577] 0,996328 4335 $\mathbf{2 4 0}$

[cal BP 4771: cal BP 4779] 0,003672

Radiocarbon Age vs. Calibrated Age

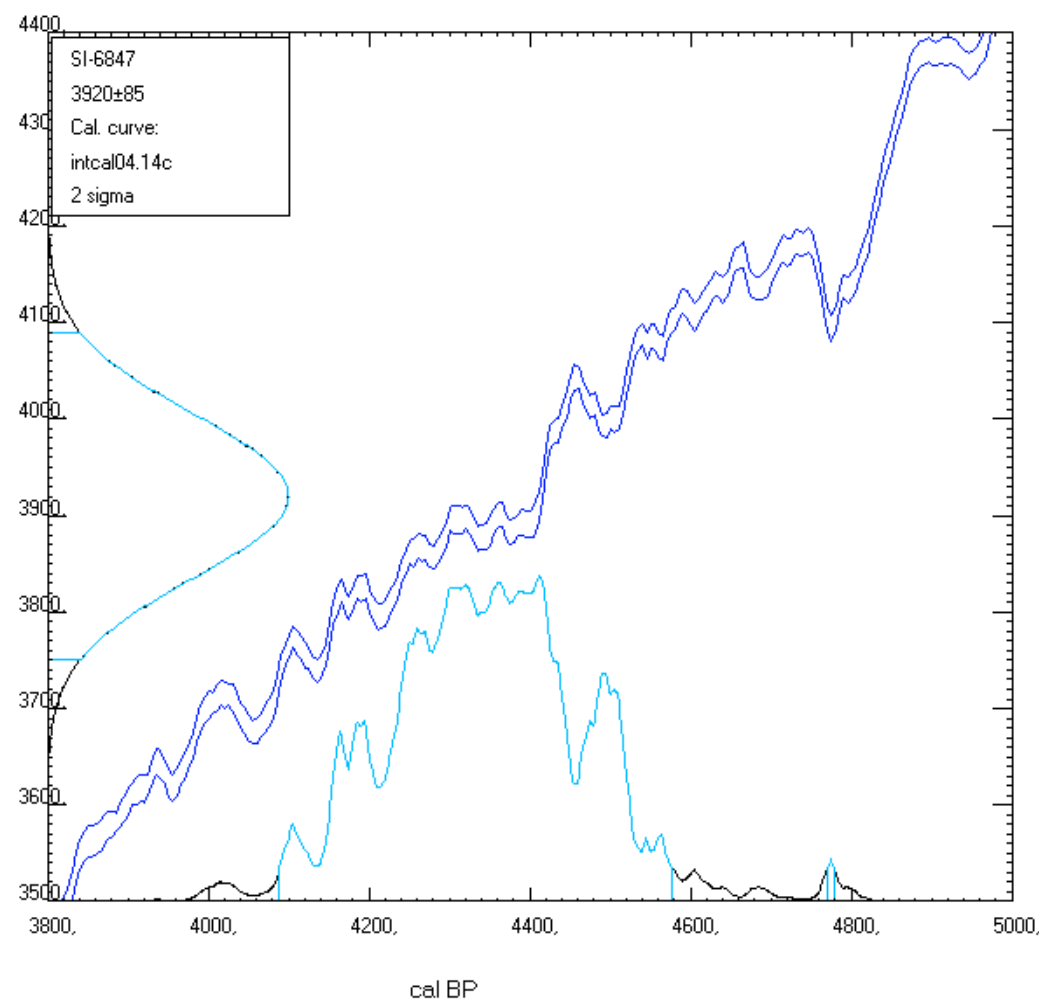


SI- 6846

RO-PN-08 Fase Bacabal

Radiocarbon Age $3580 \pm 105$

Calibration data set: intcal04.14c

\# Reimer et al. 2004

Two Sigma Ranges: [start:end] relative area

[cal BP 3590: cal BP 3600] 0,004127

[cal BP 3612: cal BP 4155] 0,992137 3885 $\mathbf{2 7 0}$

[cal BP 4208: cal BP 4219] 0,003736

Radiocarbon Age vs. Calibrated Age

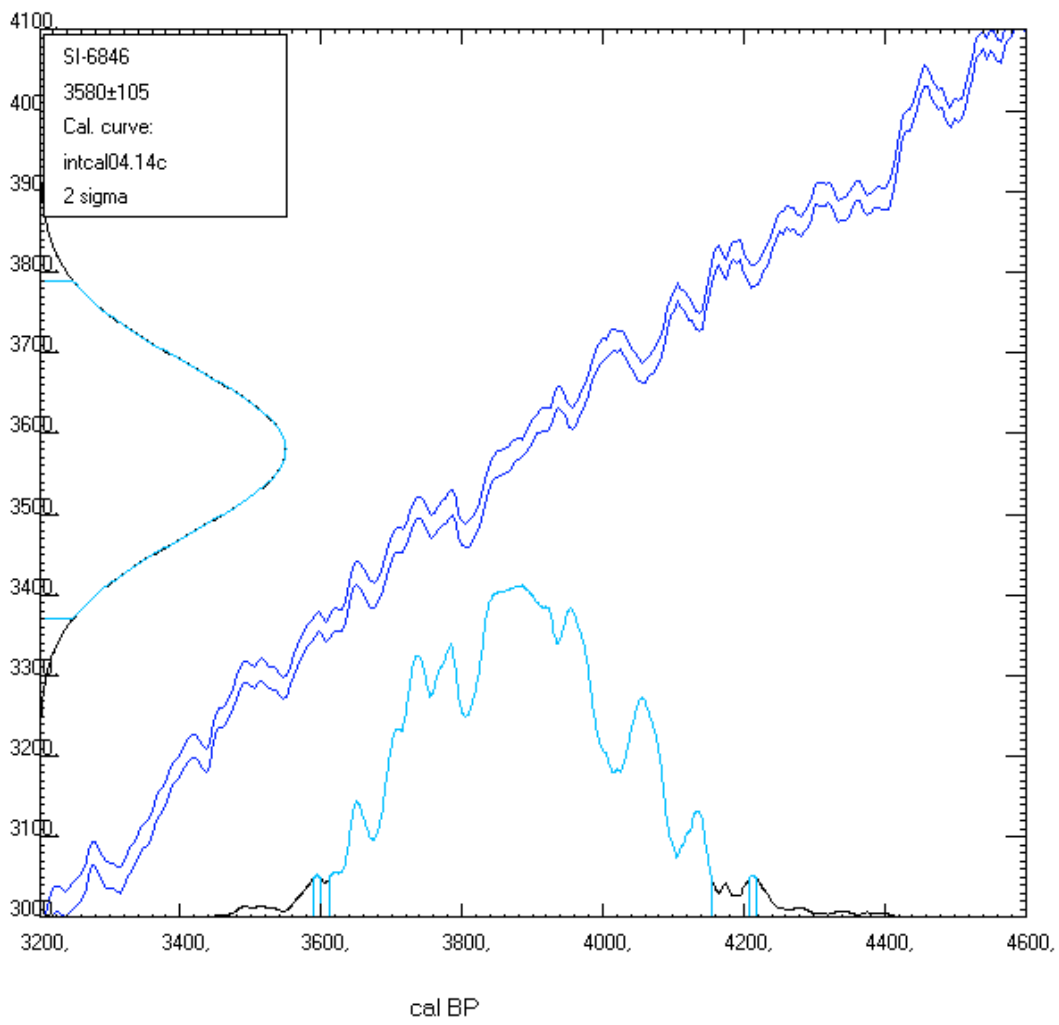


Beta 230196

Encontro

Radiocarbon Age 3850 080

Calibration data set: intcal04.14c

\# Reimer et al. 2004

Two Sigma Ranges: [start:end] relative area

[cal BP 3992: cal BP 4040] 0,034841

[cal BP 4073: cal BP 4442] 0,947658 4255 $\mathbf{1 8 5}-\mathbf{4 3 3 5 \pm 1 9 0}$

[cal BP 4483: cal BP 4512] 0,017501

Radiocarbon Age vs. Calibrated Age

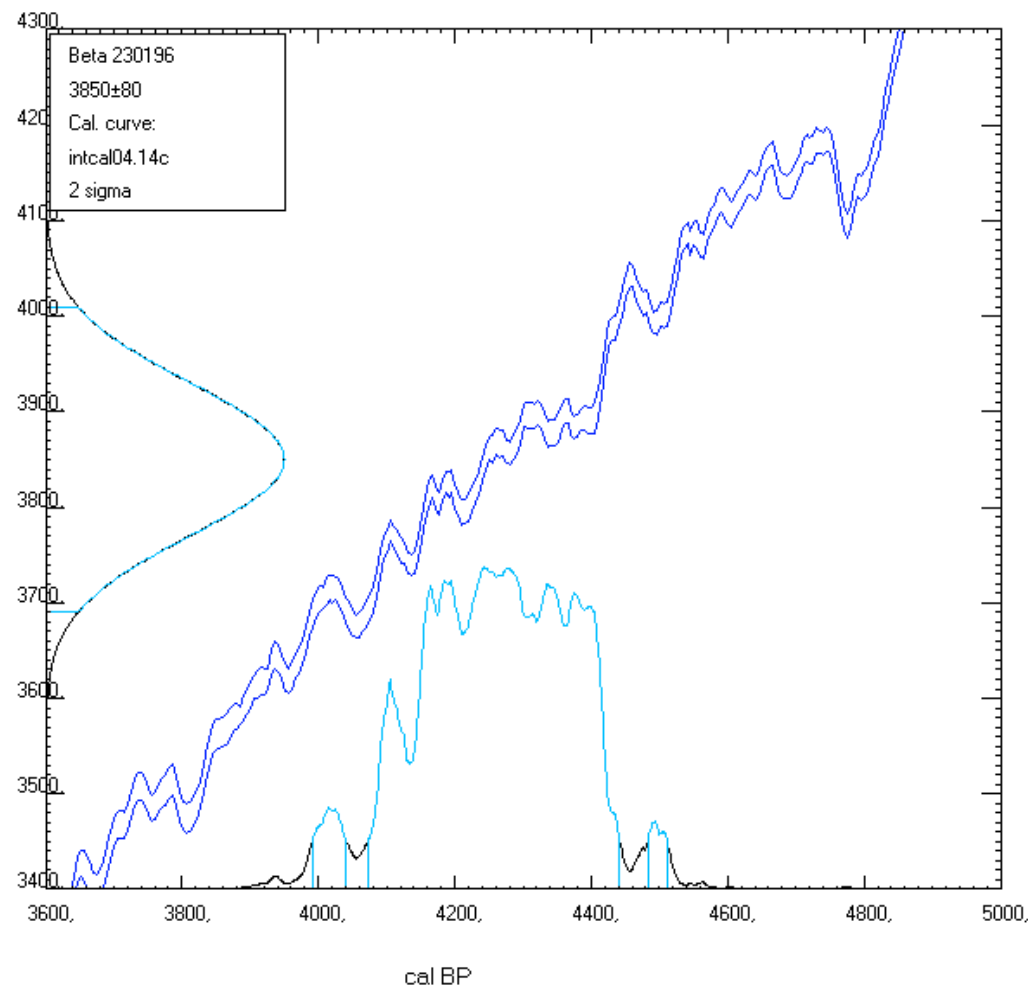


Beta 230198

Encontro

Radiocarbon Age 3910 170

Calibration data set: intcal04.14c

\# Reimer et al. 2004

Two Sigma Ranges: [start:end] relative area

[cal BP 4103: cal BP 4108] 0,00257

[cal BP 4148: cal BP 4524] 0,99743 4335 $\mathbf{1 9 0}$

Radiocarbon Age vs. Calibrated Age

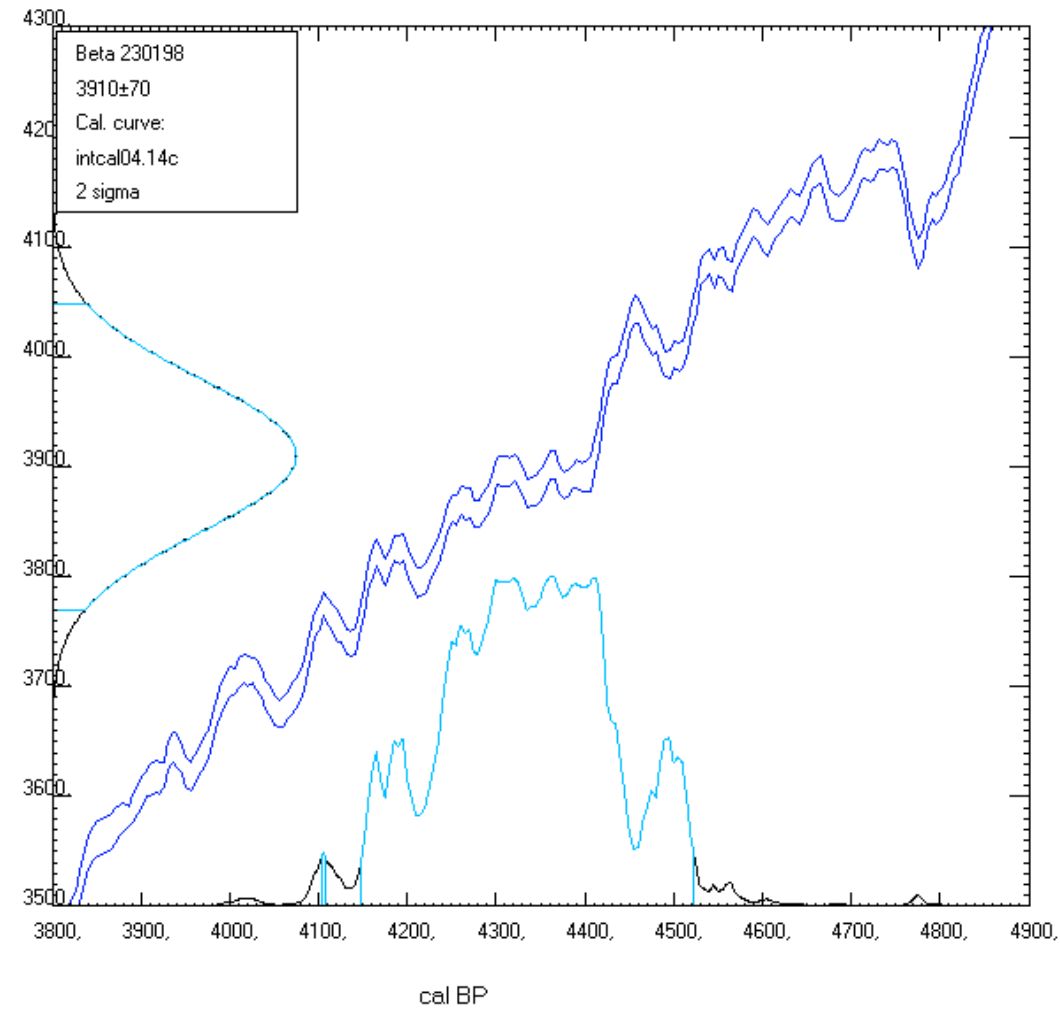




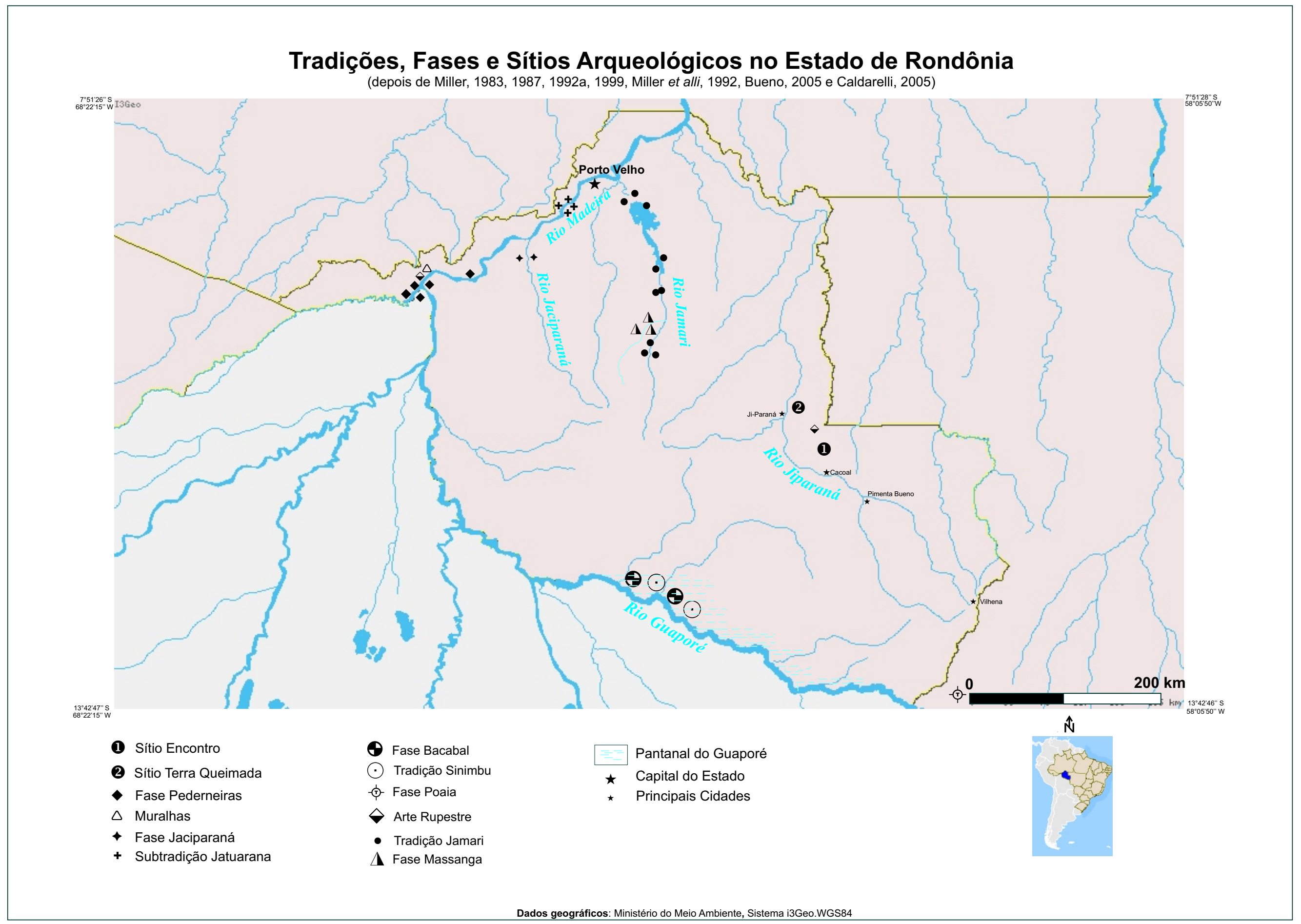




\section{Fase Jamari}

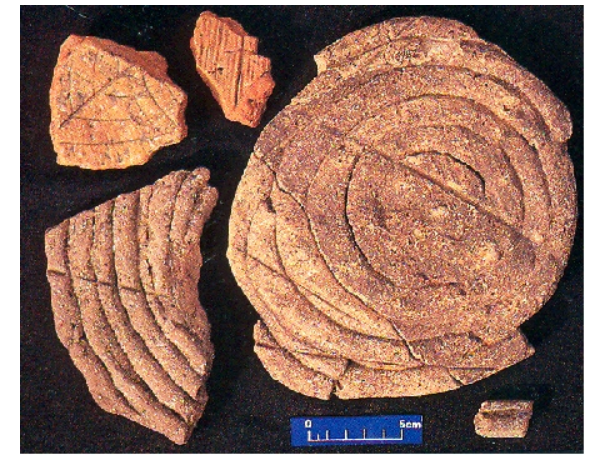

Jamari roletado e impressão de folhagem.

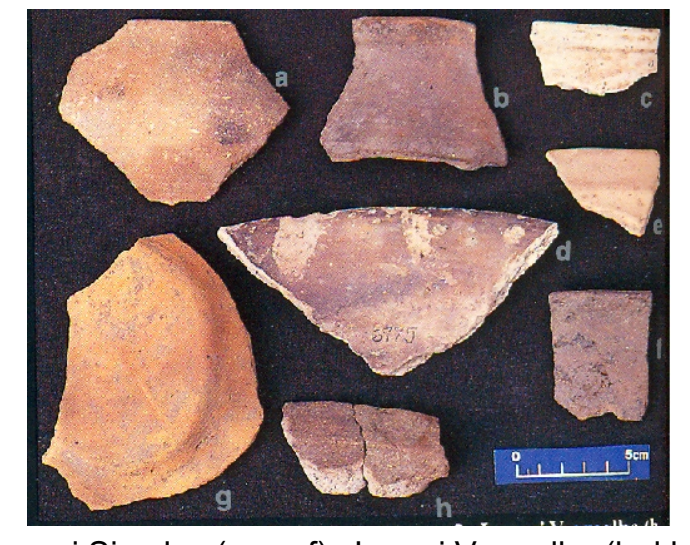

Jamari Simples (a,c,e,f), Jamari Vermelho $(b, d, h)$

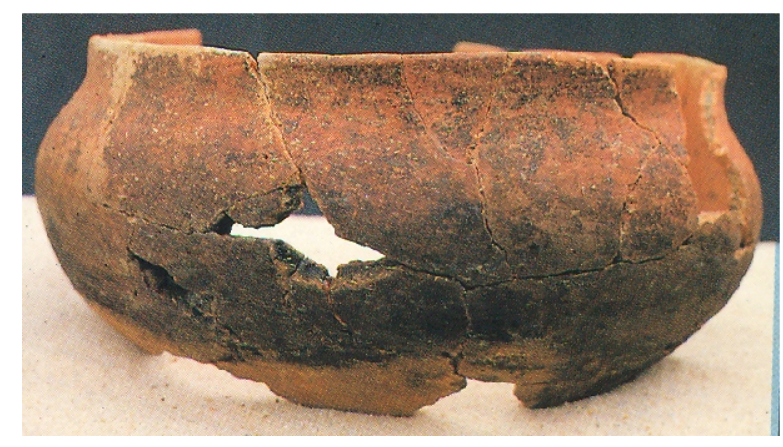

Vaso Tipo Samuel Vermelho

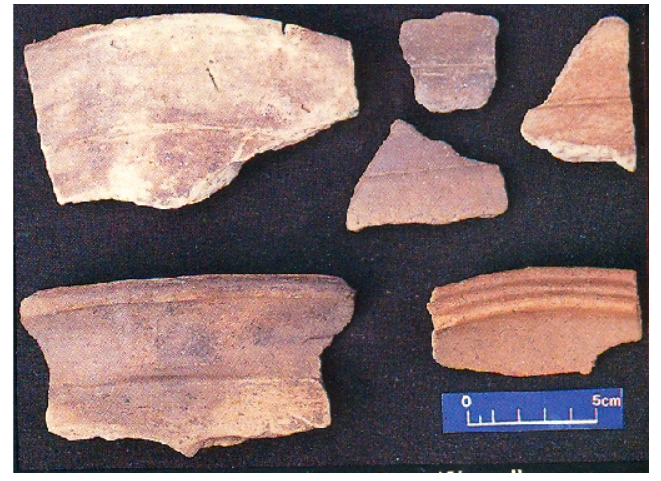

Bordas tipo Jamari Simples e Jamari Vermelho

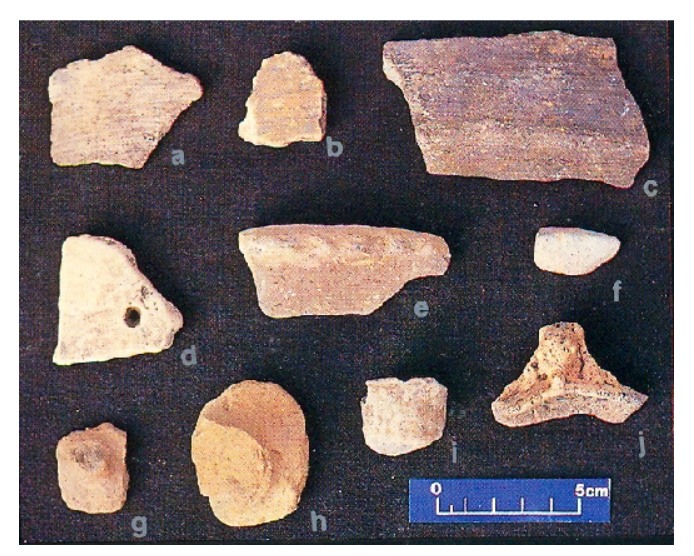

Jamari Escovado (a-c), Jamari Digitado (e,f ), Jamari Modelado $(g-\mathrm{j})$,

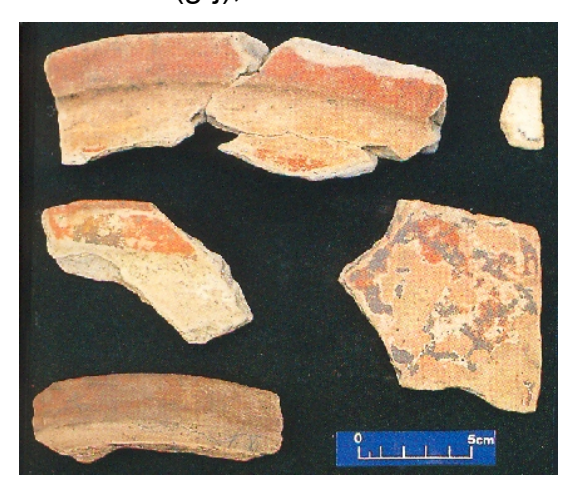

Botica Pintado

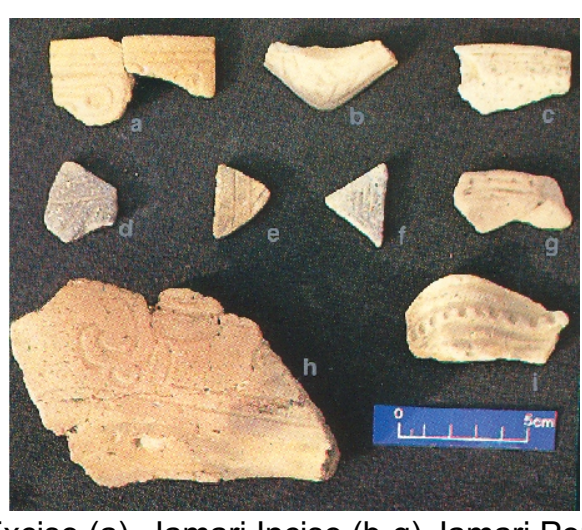

Jamari Exciso (a), Jamari Inciso (b-g), Jamari Ponteado (i) Butica Inciso $(\mathrm{h})$

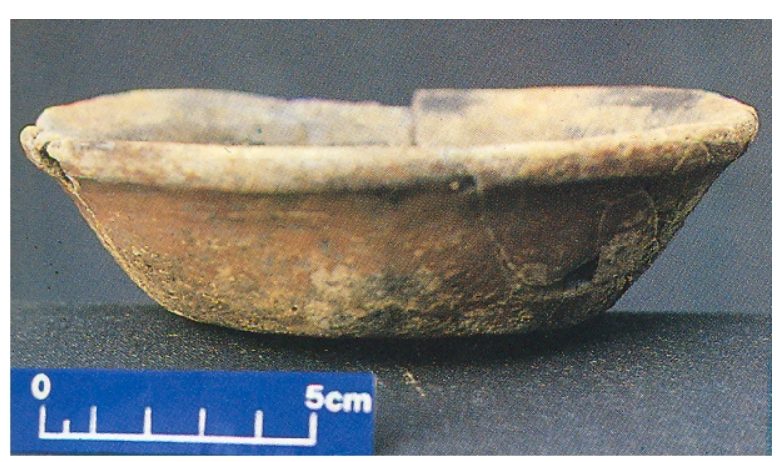

Tigela Tipo Jamari Vermelho

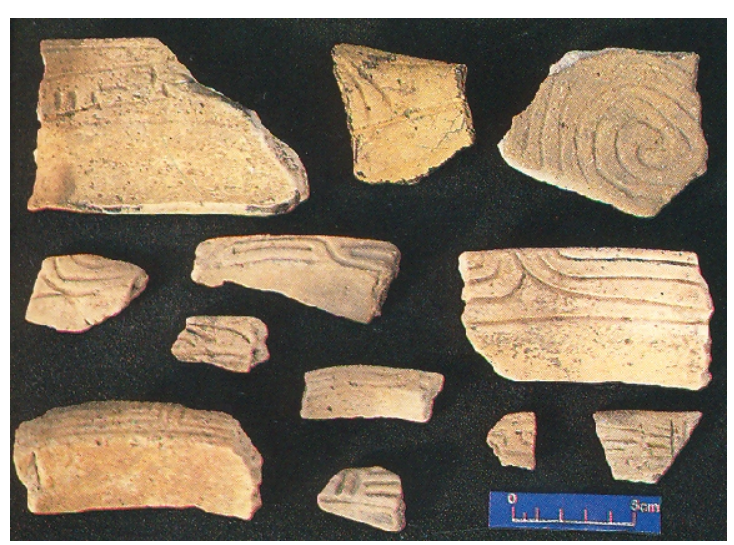

Butica Inciso, 


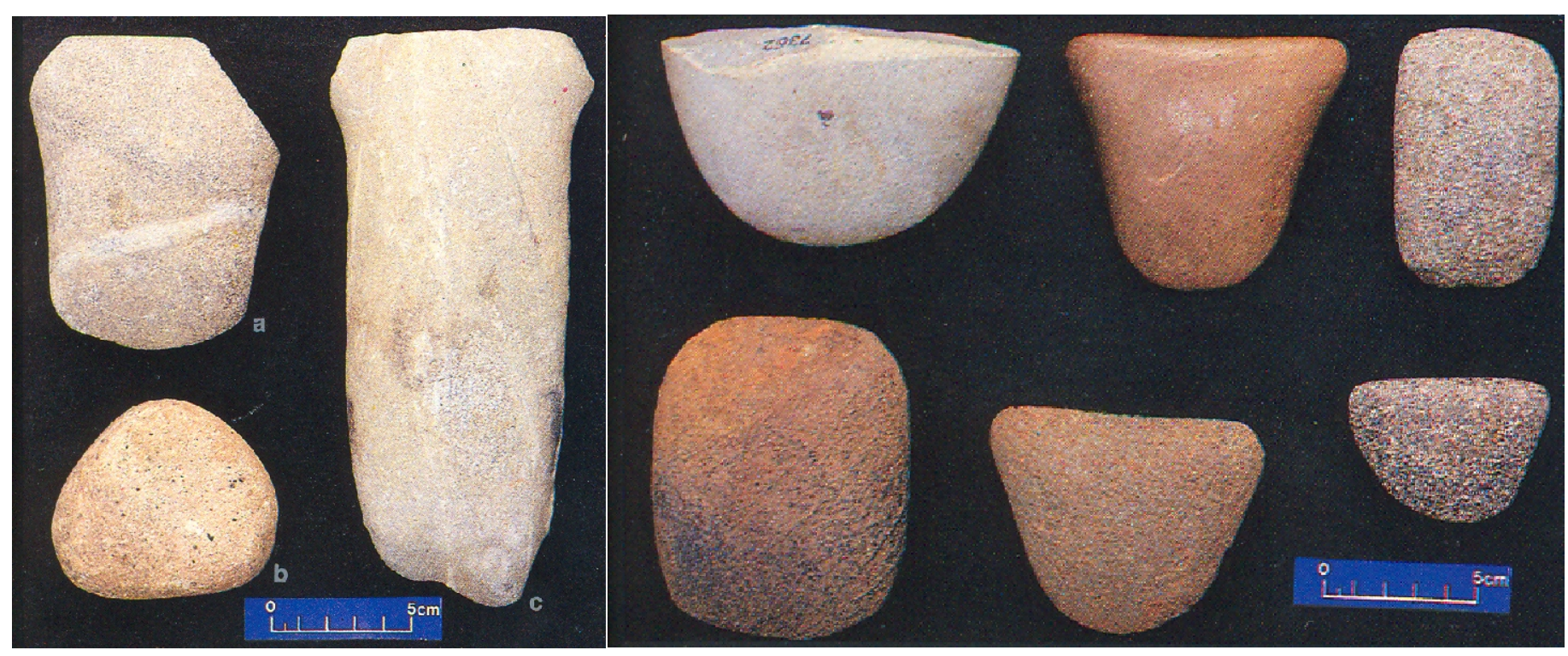

Machados polidos, Fase Jamari Miller et alli, 1992

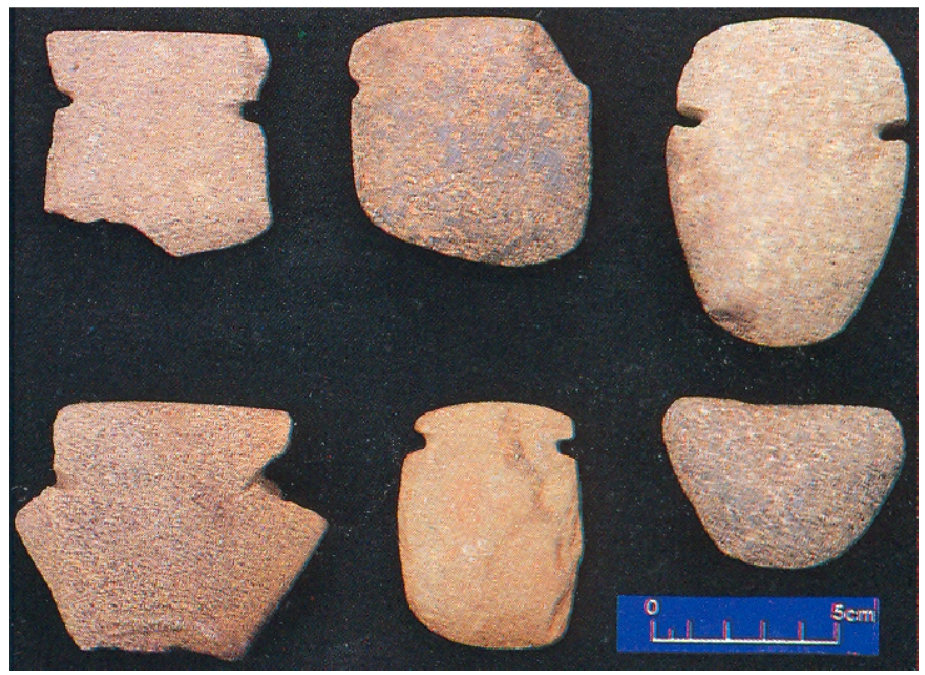

Machados polidos da Fase Cupuí,

Miller et alli, 1992 


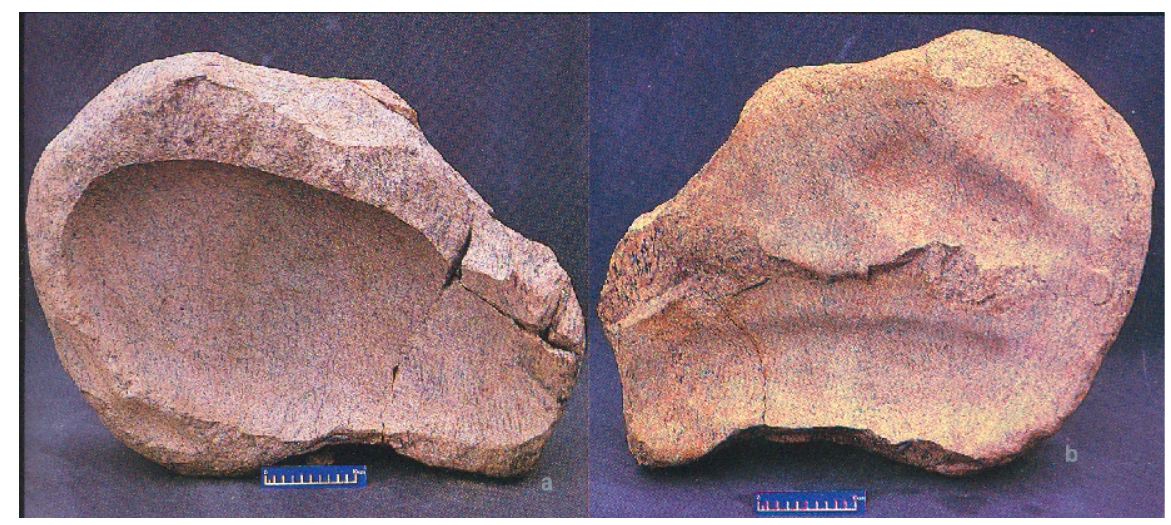

Múltiplo uso: mó, moedor e afiador, ambas as faces

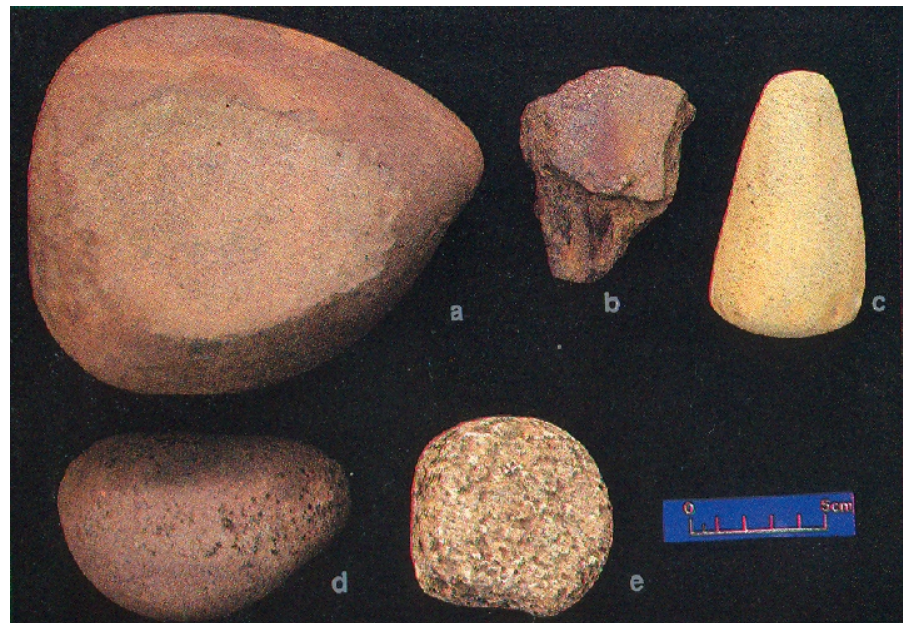

Mó , Afiador e Mão-de-pilão Fase Massangana

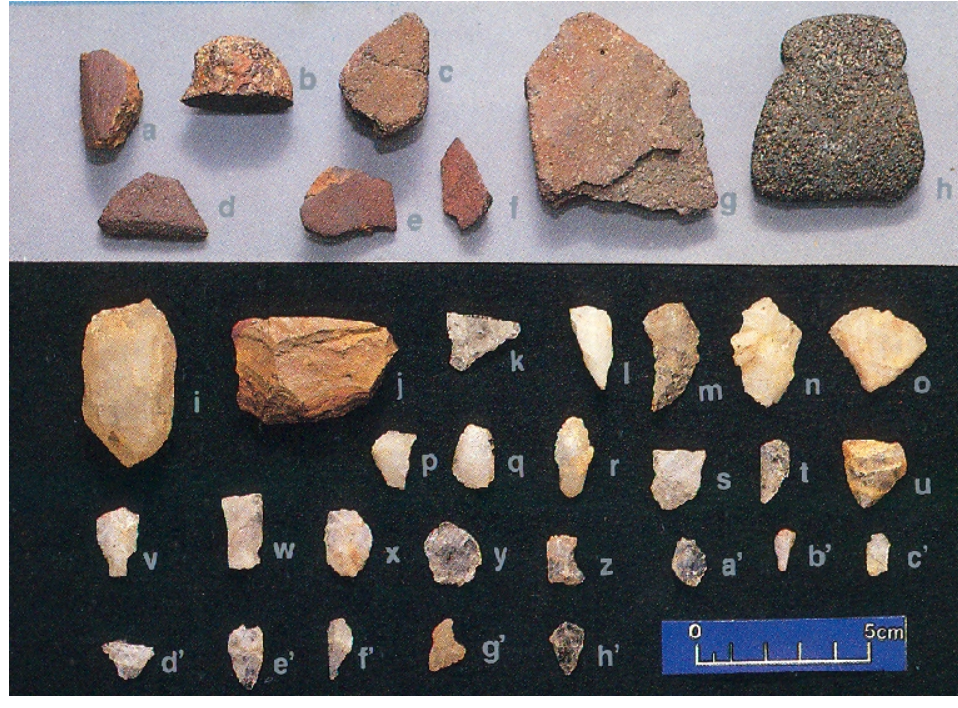

Corantes $(\mathrm{a}-\mathrm{g})$, machado polido $(\mathrm{h})$,raspadores $(\mathrm{k}-\mathrm{o})$

lascas (p-h') da Fase Massangana e Pacatuba,

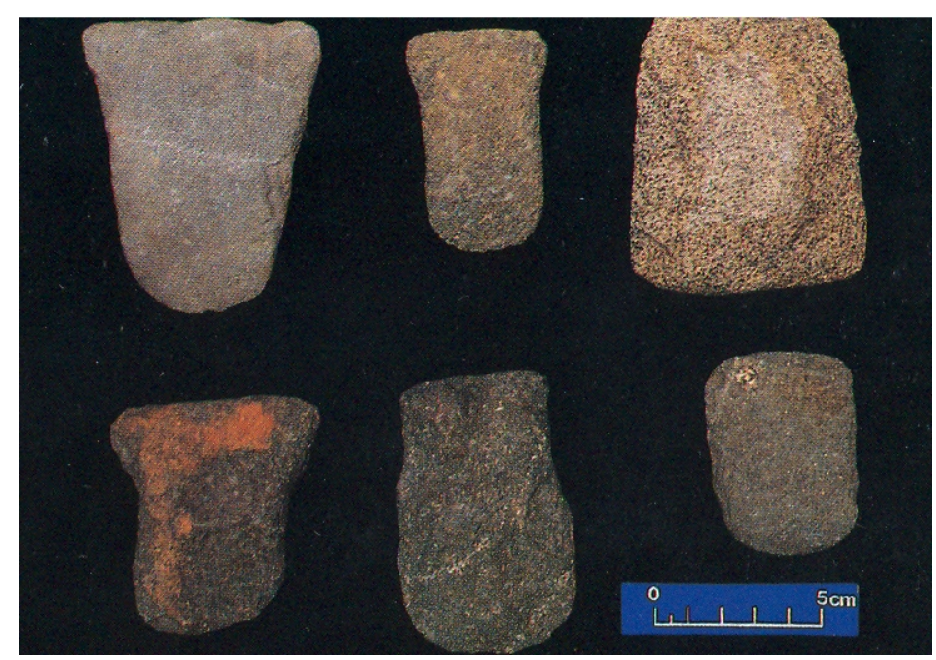

Machados picoteados (Pré-formas) 
Sítio Arqueológicos na bacia do rio Jiparaná

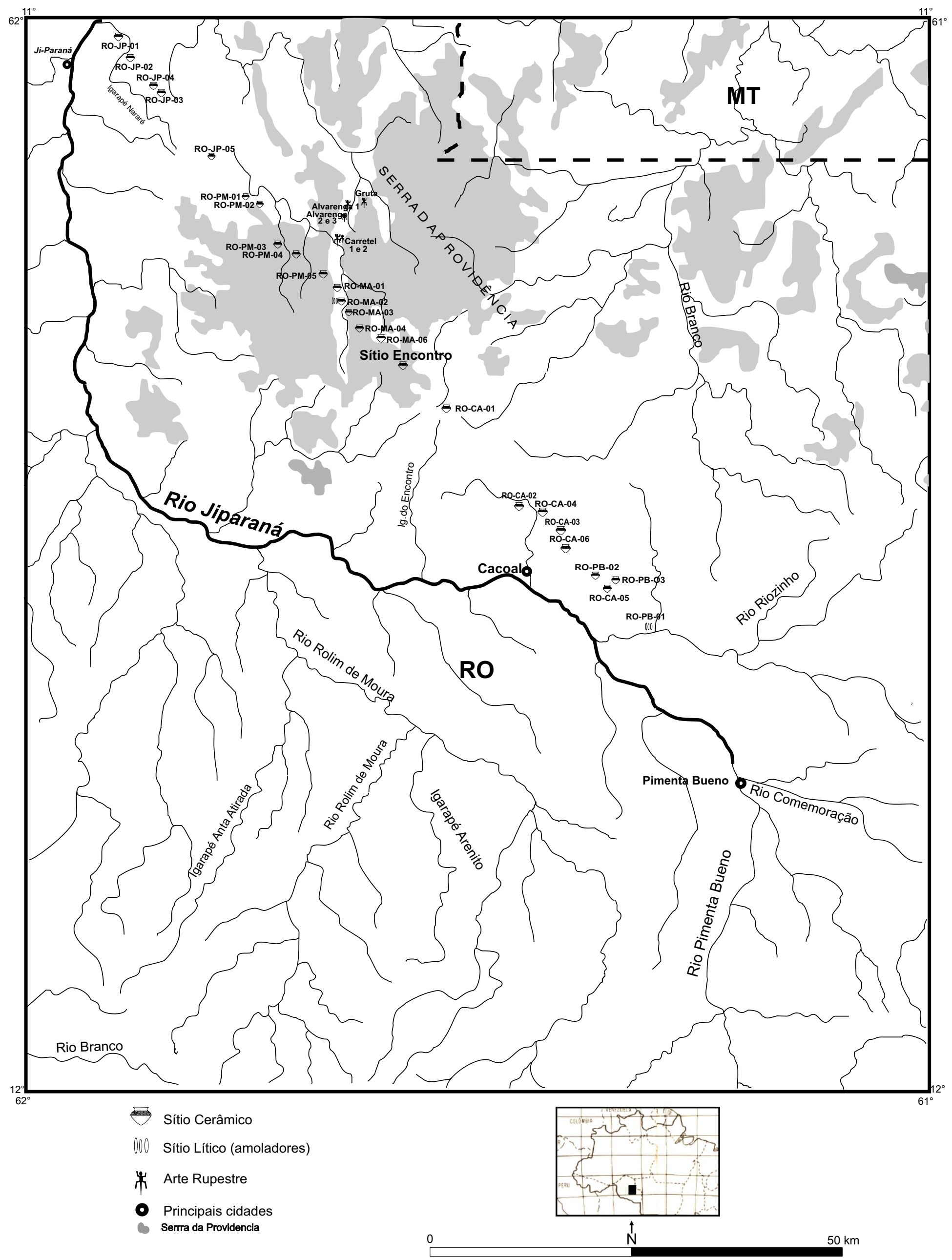




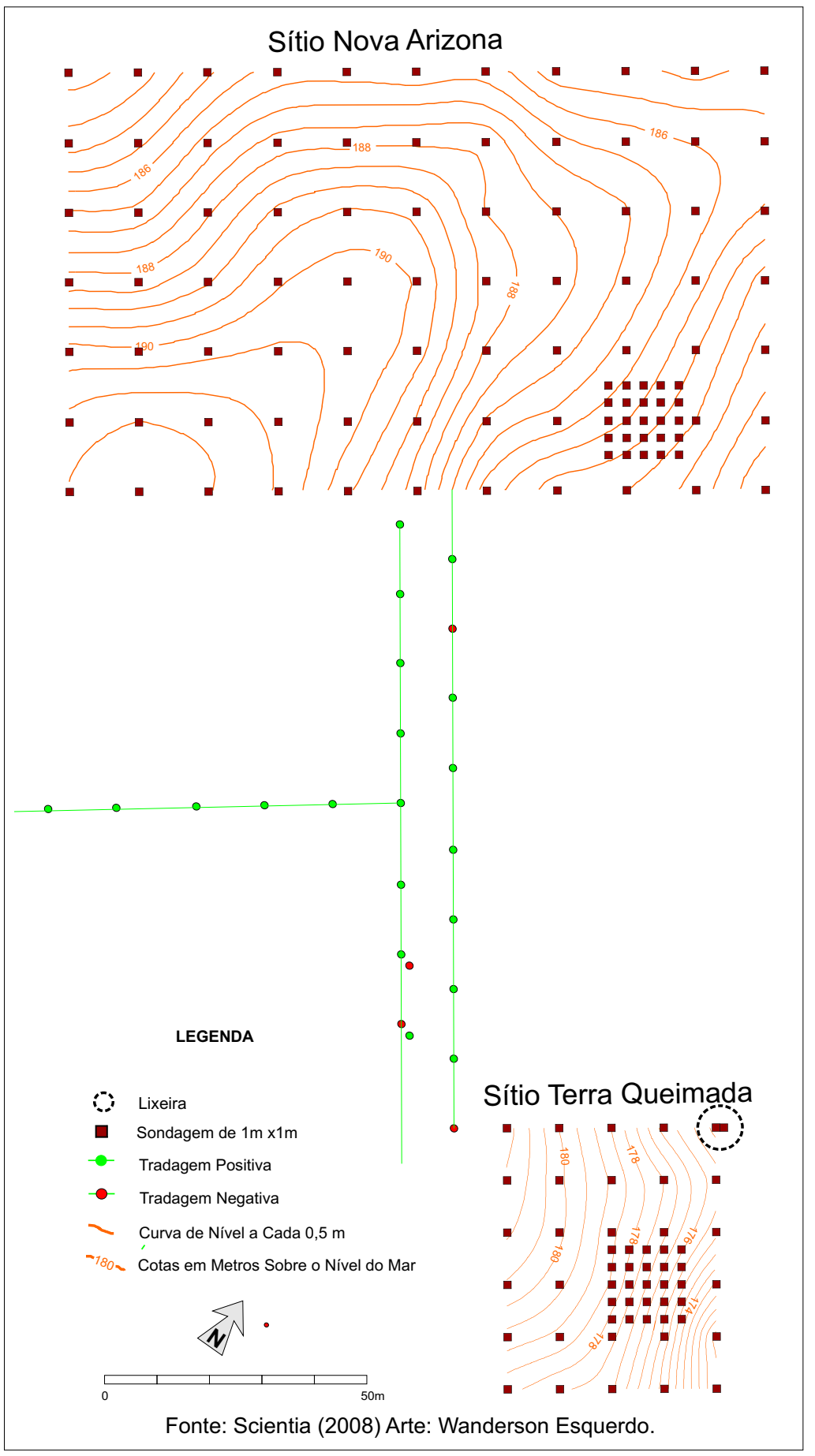

Figura 22 - Planimetria dos sitios Nova Arizona e Terra Queitamada

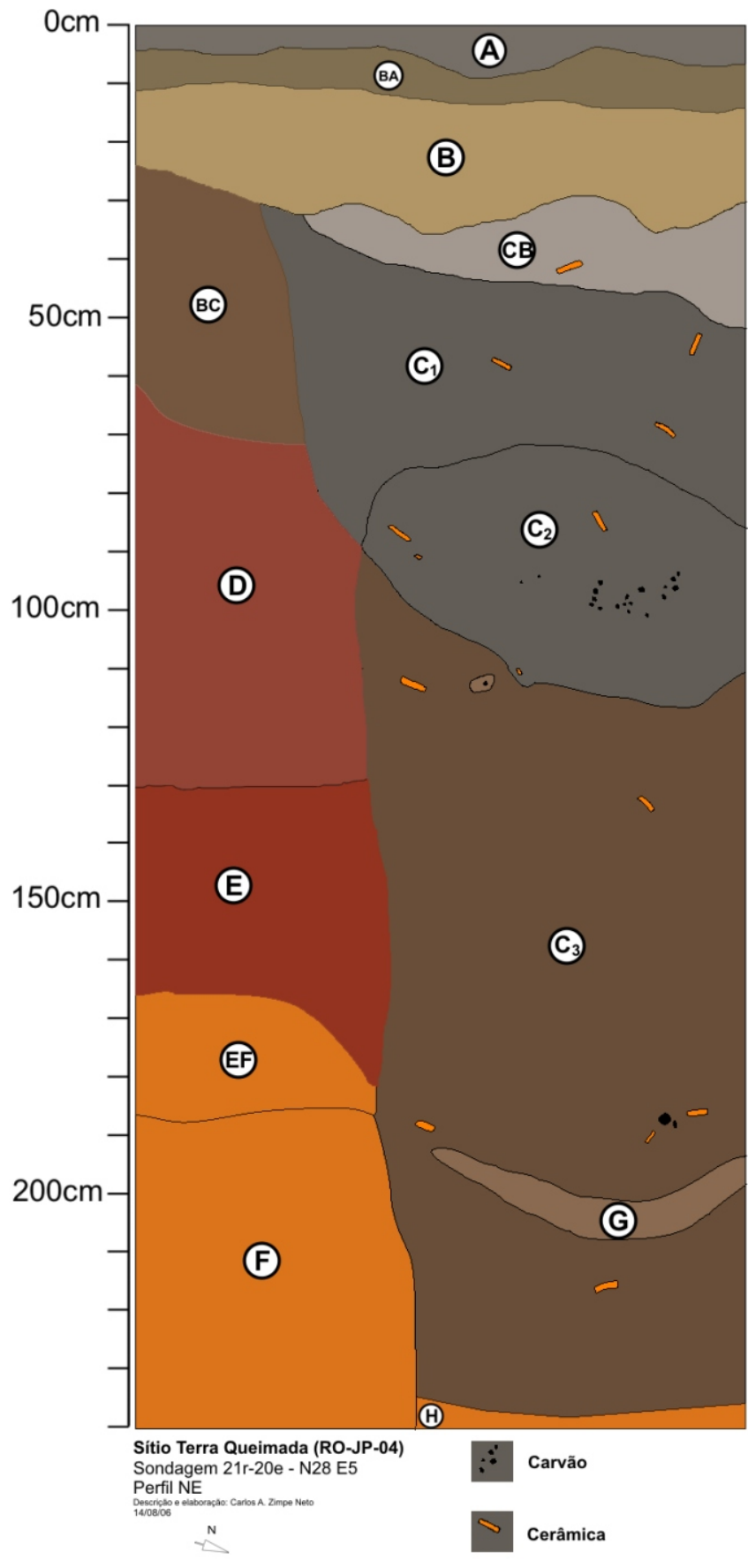

Figura 23 - A denominada Lixeira, Perfil NE.

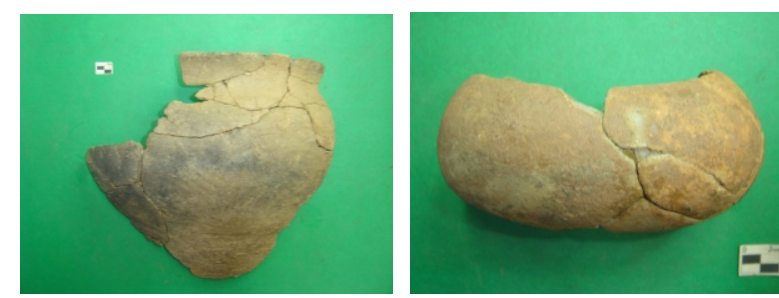

Formas reconstituídas (Beta 230194)

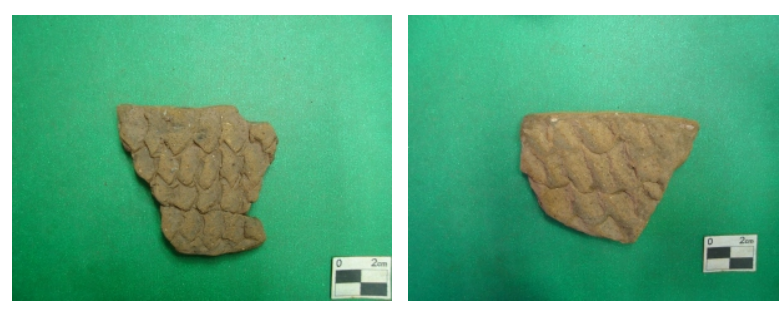

Corrugado

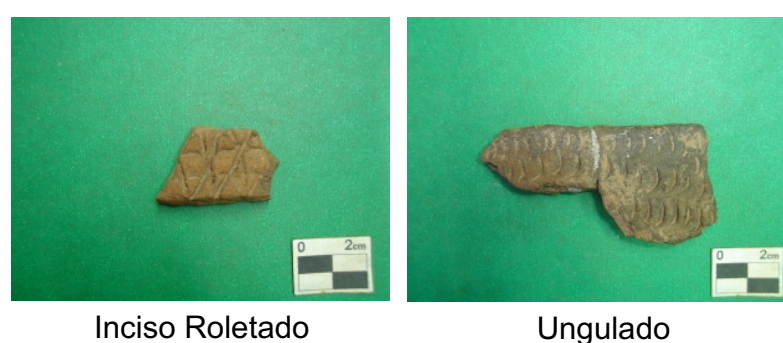

$1080 \pm 40$ AP
(Beta 230195)

Inciso Roletado

Ungulado

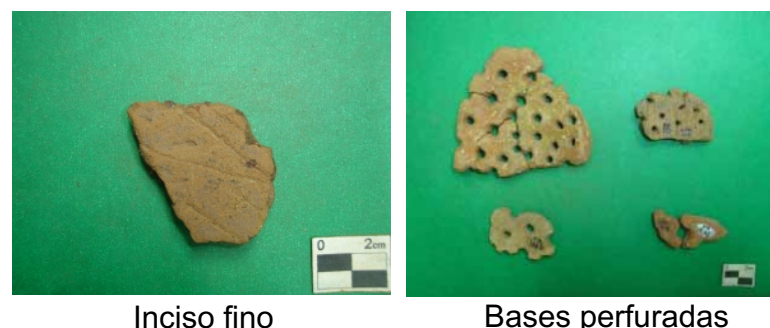

Inciso fino

Bases perfuradas

Figura 24 - Ceramica do sítio Nova Arizona 


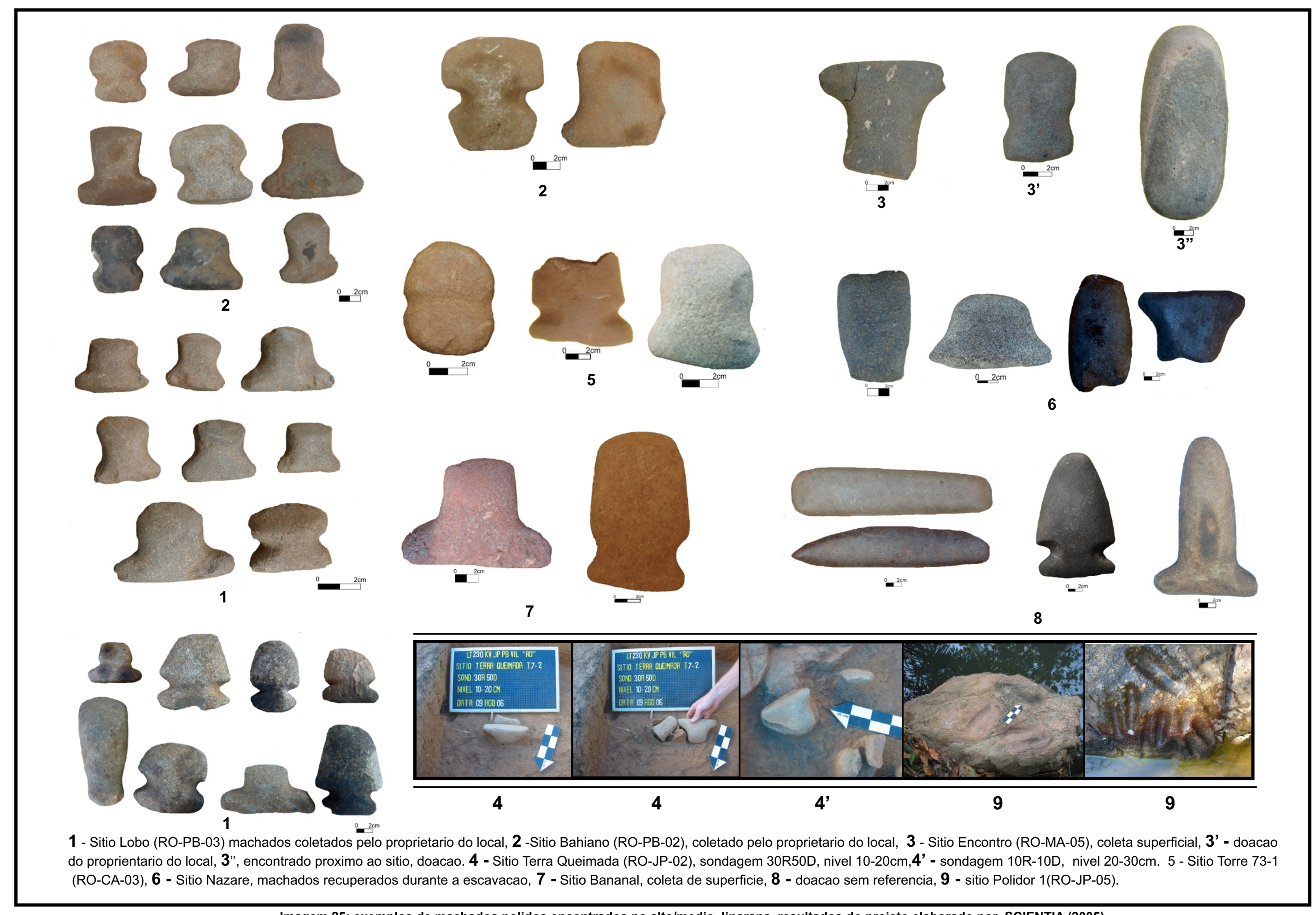

Imagem 25: exemplos de machados polidos encontrados no alto/medio Jiparana, resultados do projeto elaborado por SCIENTIA (2005) 


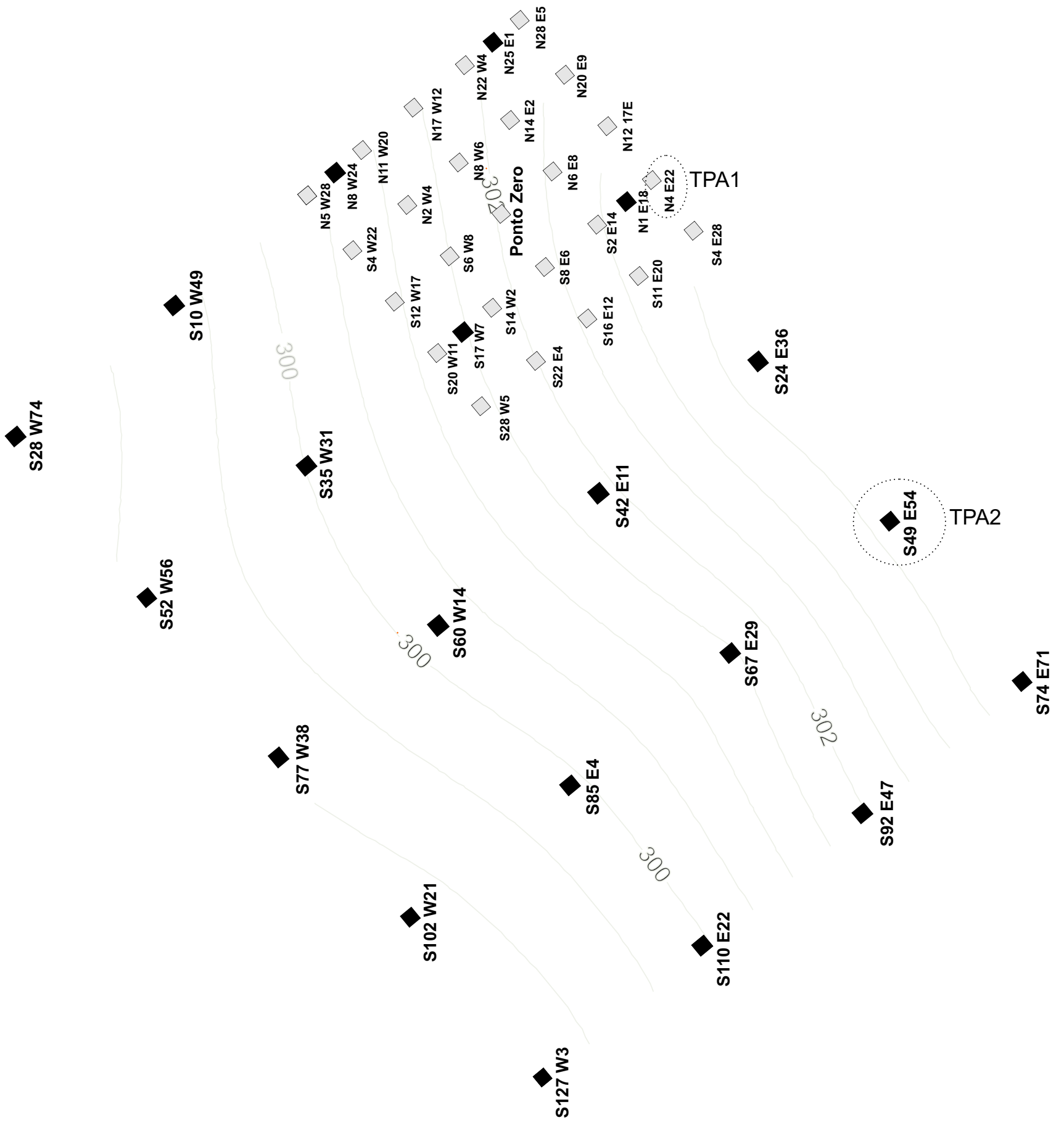

\section{Sítio Encontro}

\section{Topografia e planimetria}
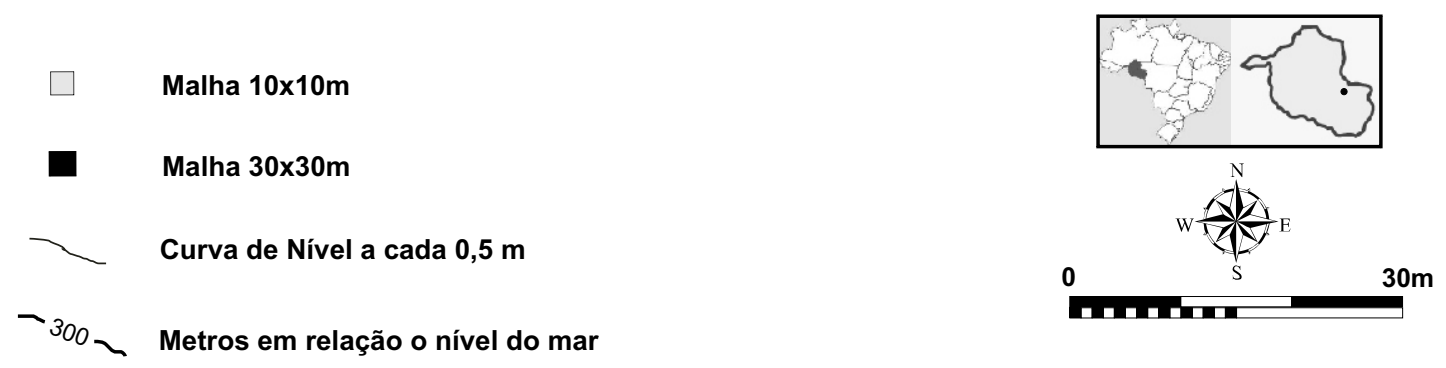


\section{Densidade Cerâmica}

Malha 10x10m

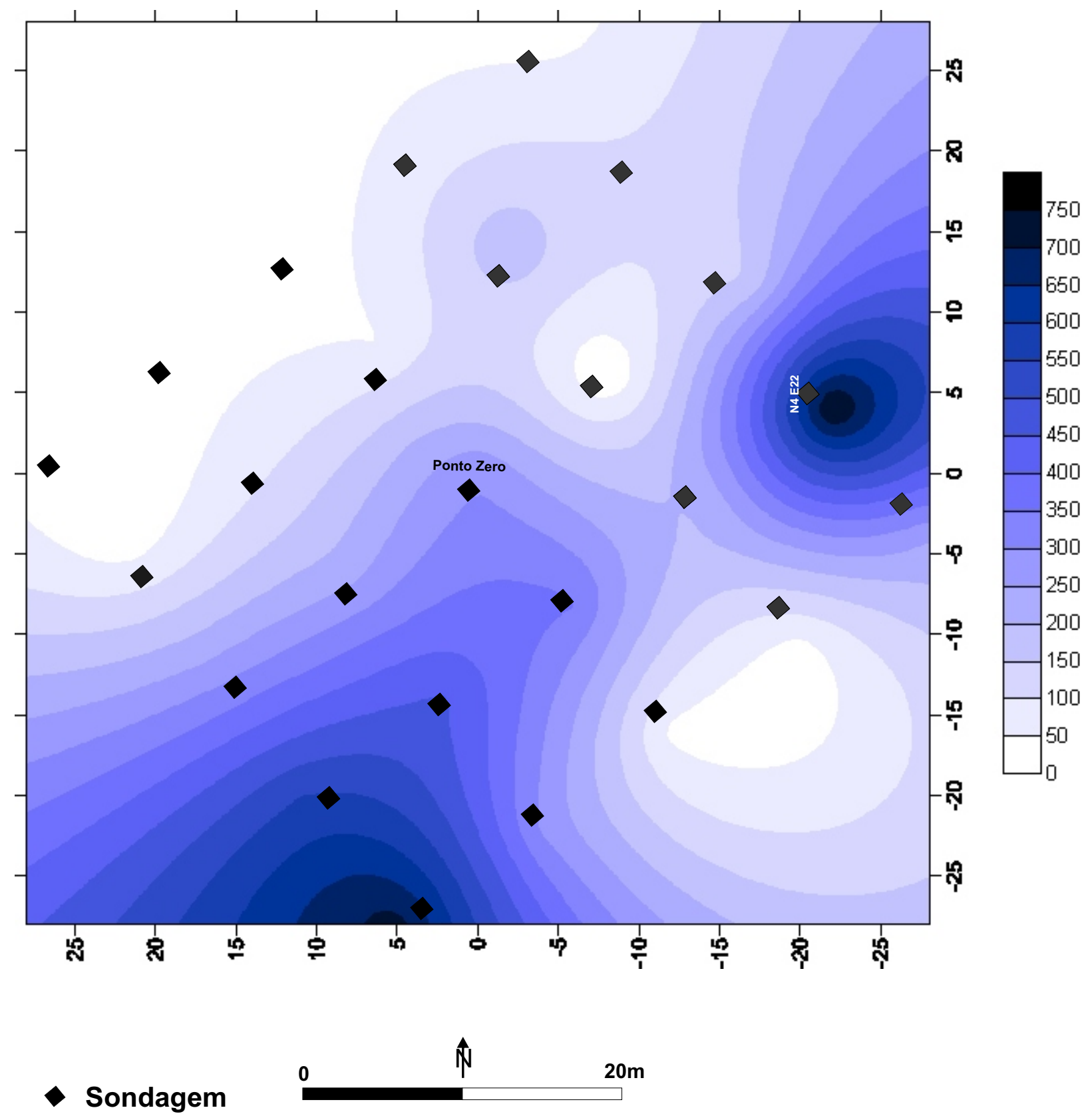

Figura 30:Representação da densidade de fragmentos cerâmica por sondagem - Malha 10x10m. 


\section{Densidade Cerâmica}

Malha 30x30m

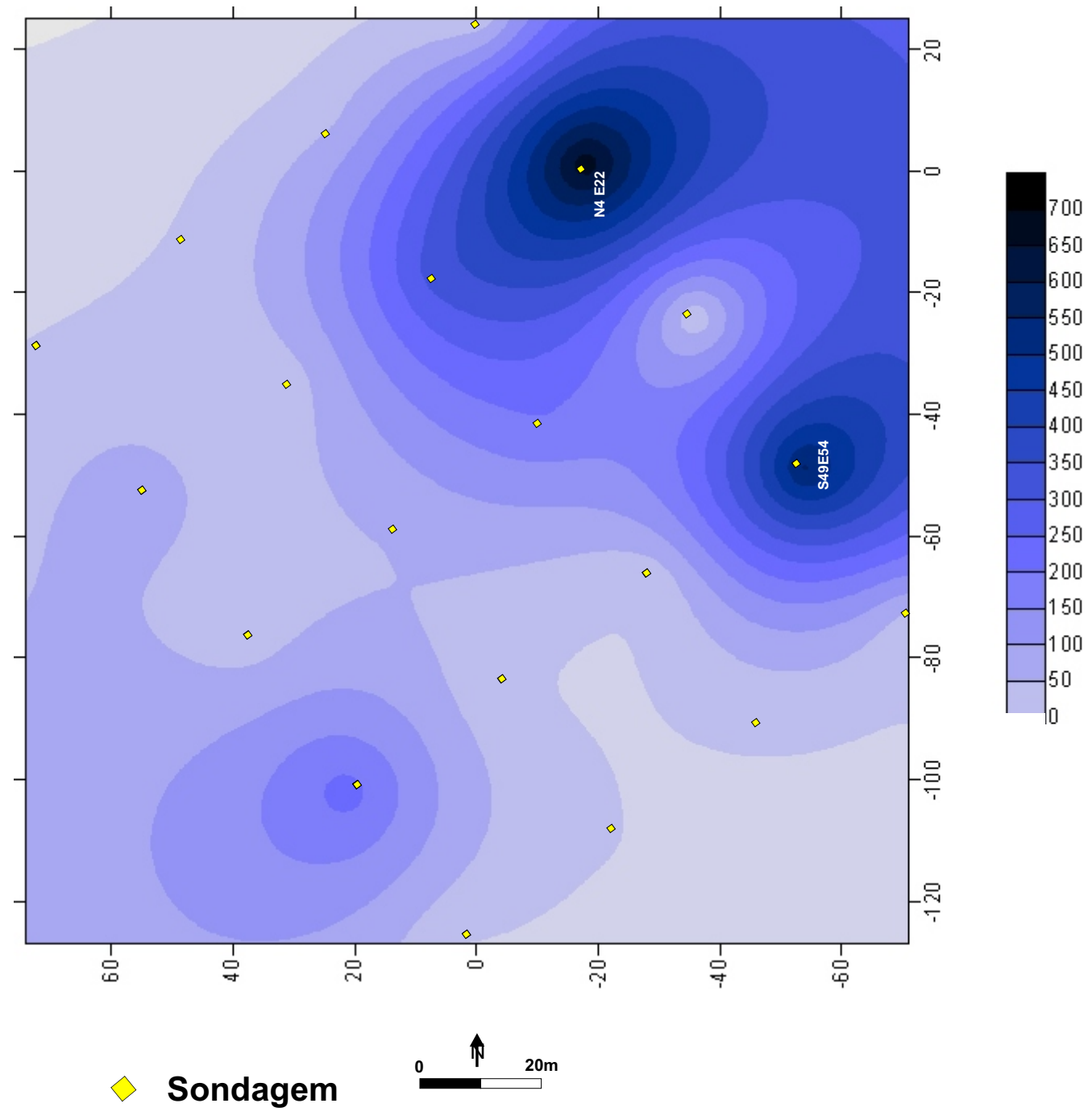

Figura 32 - Representação da densidade de fragmentos cerâmica por sondagem - Malha 30x30m. 


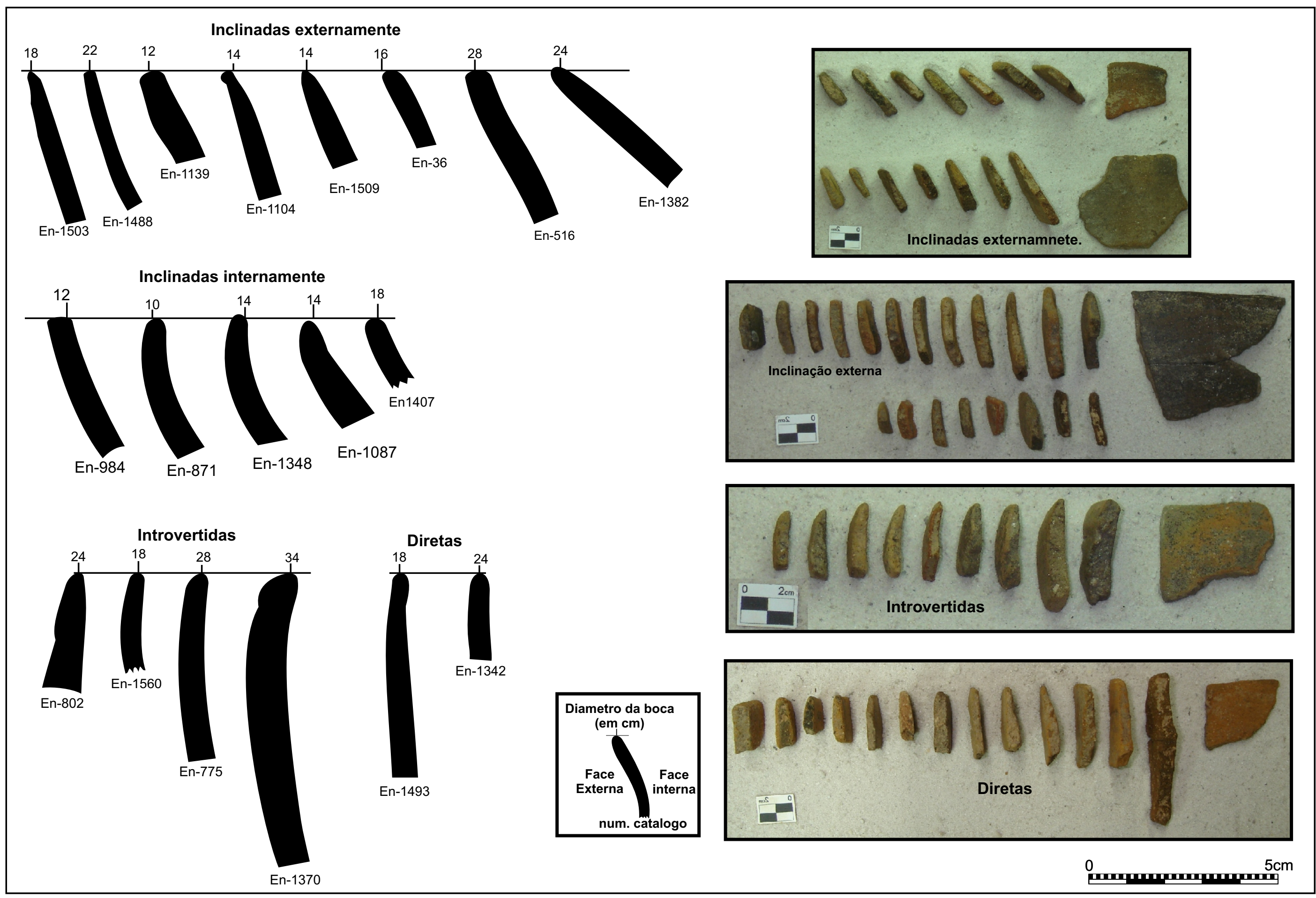




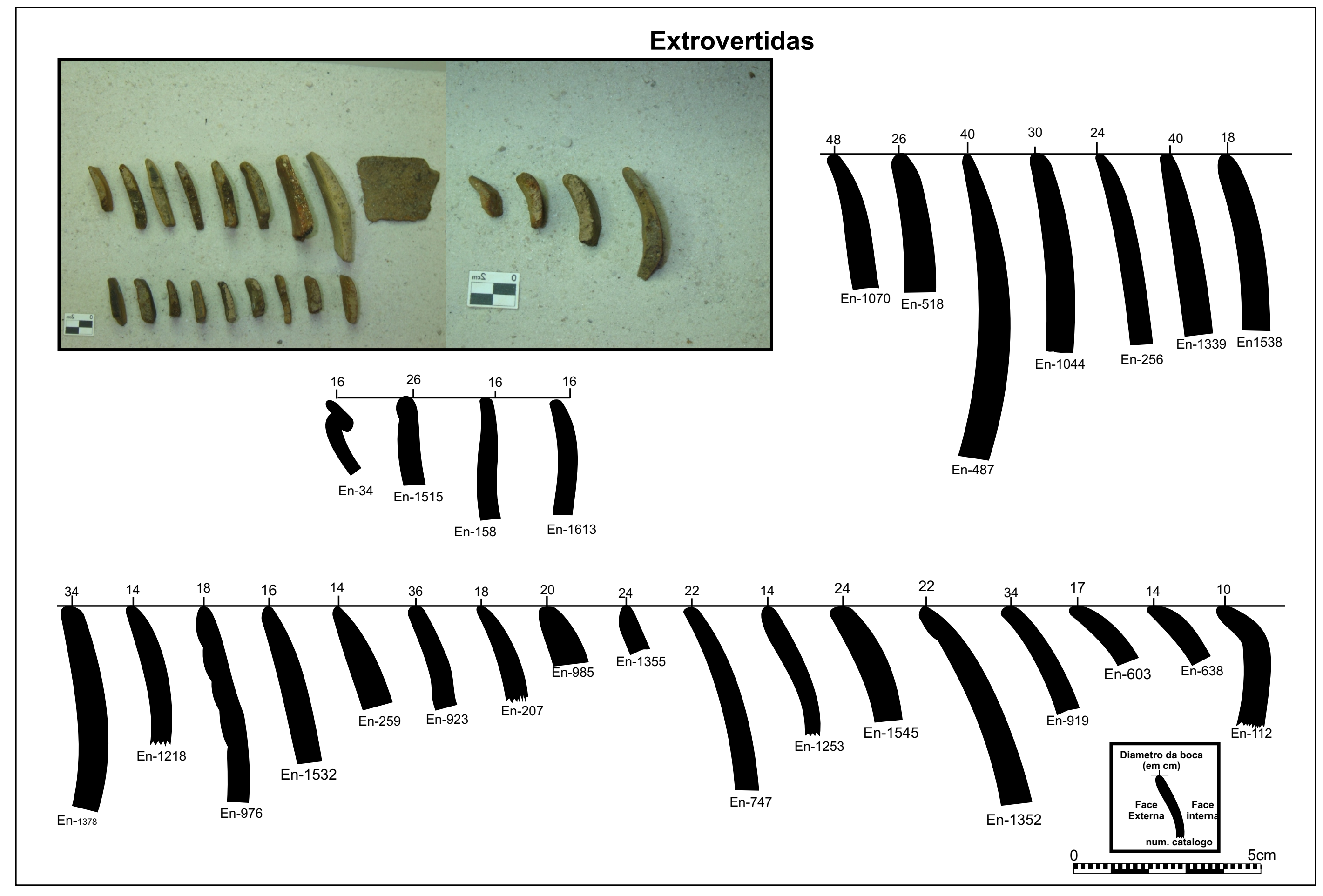




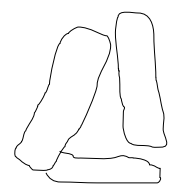

En-1520
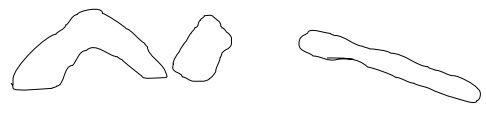

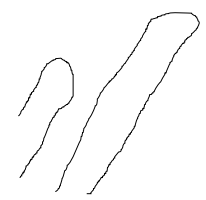

En1105

En-262

$2 \mathrm{~cm}$

Pintura branca sobre engobo vermelho

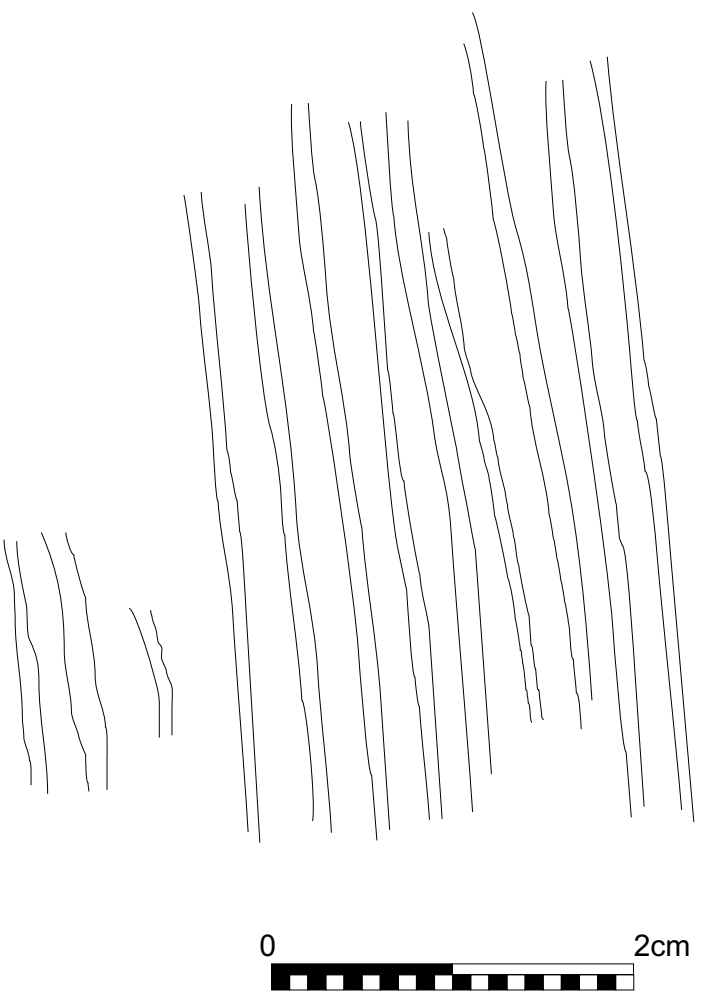

Pintura branca sobre sobre superficie alisada

En-834
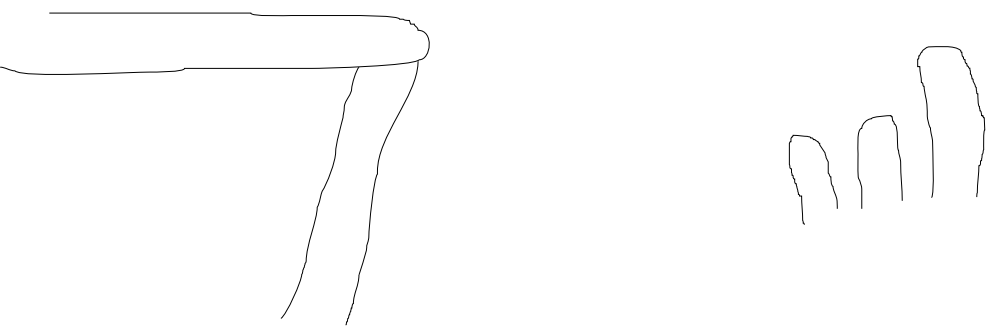

En-236

0

$2 \mathrm{~cm}$

En-299

Pintura preta(?) sobre sobre superficie alisada

Imagem 50: motivos identificados na cerâmica pintada 


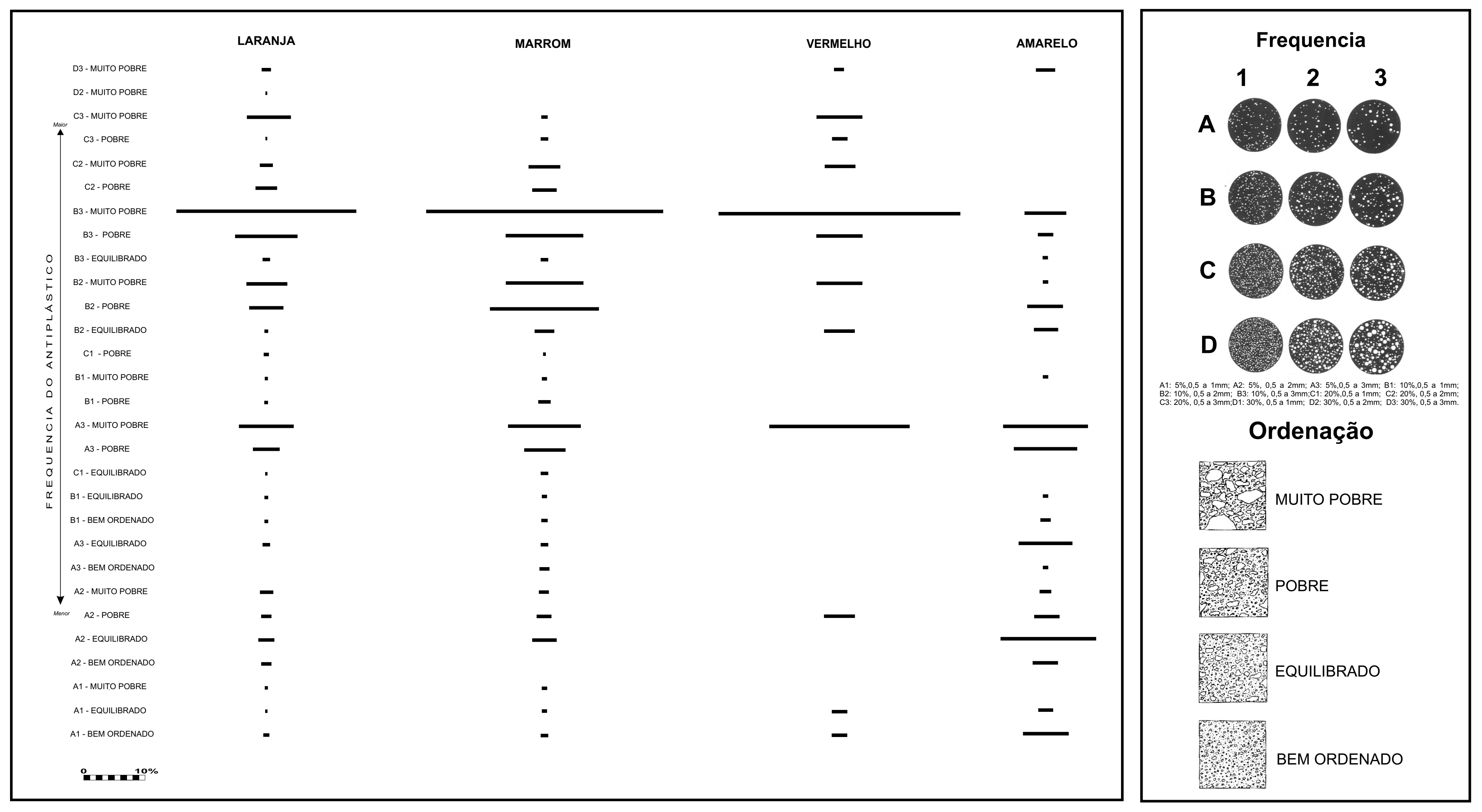

Gráfico 23: Comparação entre as cores 


\section{TPA-1}

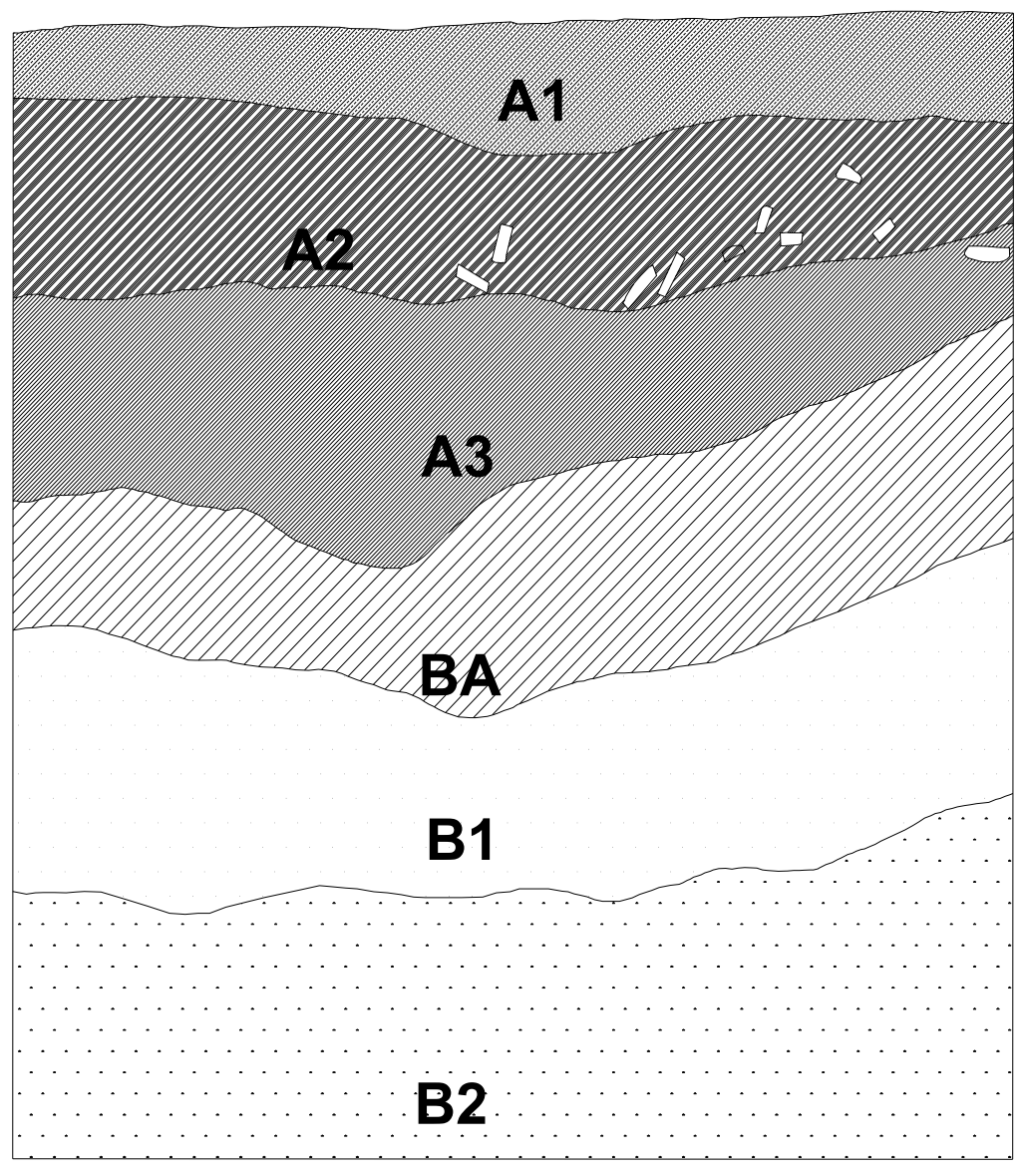

$0.5 \mathrm{~m}$

\section{Descrição morfológica do perfil de solo}

Descrito e coletado em uma sondagem de $1 \mathrm{~m} \times 1 \mathrm{~m} \times 1,2 \mathrm{~m}$, em um local plano com cobertura vegetal de pasto. Vegetação original ausente. Próximo mais ou menos $50 \mathrm{~m}$ de uma mangueira. No local são criados cavalos e vacas. O Perfil SE foi escolhido para descrição.

A1 $(0-12 \mathrm{~cm})$ Coloração do solo úmido é 10YR 4/1 úmido, textura arenosa, consistência é solta, quase macia, muito friável, com o solo úmido, não plástica, não pegajosa, estrutura fraca, se desfaz en pequenos blocos angulares e subangulares muito pequenos a pequenos, raízes poucas de finas a médias. Material Arqueológico.

A2 $(12-29 \mathrm{~cm})$ Coloração do solo é 10YR 4/2 úmido, textura arenosa, Consistência solta, friável. A consistência do solo quando úmido é não pegajoso e não plástico plásticoA estrutura é fraca, solta, friável e se desfaz

em pequenos blocos subangulares, raízes muitas e finas. Material arqueológico

A3 (29-58cm) Coloração do solo é 10YR 2/1 úmido. Textura arenosa, Consistência macia a ligeiramente dura. A consistência do solo úmido é não pegajoso e não plástico.A estrutura é fraca, ligeiramente macia, friável e se desfaz em muito pequenos a pequenos blocos subangulares. Raras raízes muito finas a finas, Material arqueológico.

BA (57-68cm) Ccoloração do solo é 7,5YR 4/2 úmido, a textura é arenosa, com mais argila que os horizontes anteriores. Quando seco a consistência é Ligeiramente dura A consistência do solo quando úmido é ligeiramente pegajoso e não plástico.A estrutura moderada, se desfaz em pequenos blocos subangulares pequenos. Presença de raízes raras e finas. Ocorrência de material arqueológico.

B1 $(68-85 \mathrm{~cm})$ Ccoloração do solo é 25YR 4/8 úmido, a textura do solo é argiloarenosa.Consistência ligeiramente dura. A consistência do solo quando úmido é pegajoso e plástico $A$ estrutura forte, se desfaz em pequenos blocos subangulares e angulares, : Mosqueado vermelho, poucos e pequenos. Raízes raras e finas. Sem Material arqueológico.

B2 $(85-130 \mathrm{~cm})$ Ccoloração do solo é 2,5YR 5/8 úmido, a textura é argiloarenosa. Consistência Ligeiramente dura a firme. A consistência quando solo está úmido é pegajoso e plásticoA estrutura forte, se desfaz em pequenos blocos subangulares. As raízes são raras e finas nesse horizonte. Sem material arqueológico.

\begin{tabular}{cccccc} 
Horizonte & produndidade & Areia Grossa & Areia Fina & Argila & Silte \\
\hline A1 & $0-12 \mathrm{~cm}$ & 59 & 13 & 12 & 16 \\
A2 & $12-29 \mathrm{~cm}$ & 66 & 12 & 8 & 14 \\
A3 & $29-58 \mathrm{~cm}$ & 69 & 14 & 11 & 6 \\
BA & $56-68 \mathrm{~cm}$ & 22 & 10 & 41 & 27 \\
B1 & $68-85 \mathrm{~cm}$ & 39 & 14 & 22 & 25 \\
B2 & $85-130 \mathrm{~cm}$ & 54 & 22 & 15 & 9
\end{tabular}

Tabela : resultado da análise da textura do solo, S49E54 


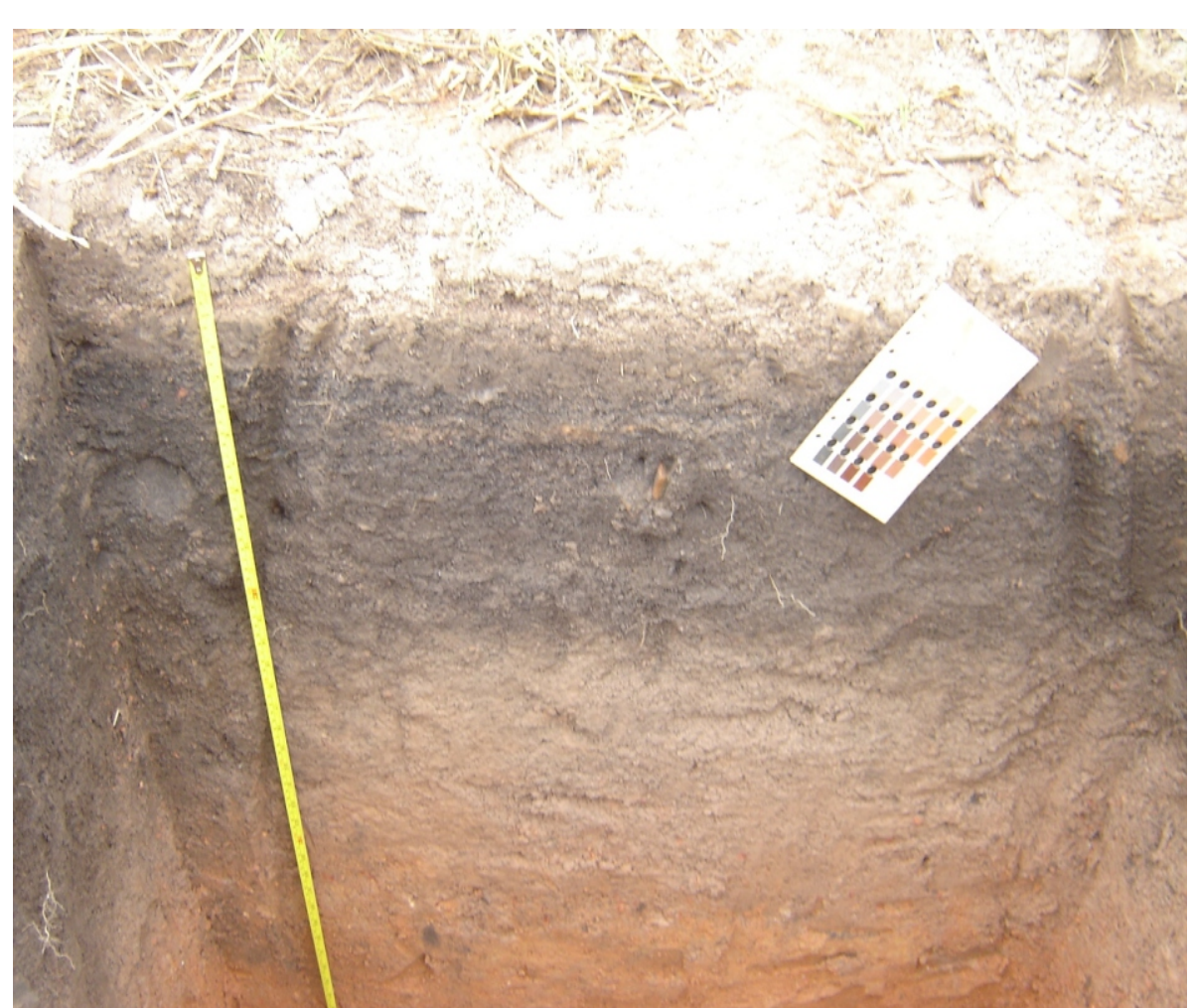

Imagem : Perfil SE, N4E22
PERFIL SE Vegetação é pasto, o relevo é suave ondulados, o solo deve ter derivado de rochas básicas, com características de argissolo vermelho.

A1 $(07 / 8 \mathrm{~cm})$ a coloração do solo é 10YR 4/1 úmido, a textura é arenosa. A consistência do solo quando úmido é não pegajoso e não plástico; muito poroso;A estrutura é forte e se desfaz em pequenos a grandes blocos subangulares. transição clara e irregular; raízes são muitas e finas. Ocorrência de material arqueológico.

A2 $(7 / 812 / 13 \mathrm{~cm})$ a coloração do solo é 10YR 4/2 úmido, com textura arenosa. A consistência do solo quando úmido é não pegajoso e ligeiramente plástico; muito poroso;A estrutura é fraca, solta, friável e se desfaz em pequenos blocos subangulares e grãos simples. transição clara e irregular; raízes muitas e finas. Ocorrência de material arqueológico.

A3 $(12 / 1334 / 37 \mathrm{~cm})$ a coloração do solo é 10YR 2/1 úmido, a textura é arenosa.A consistência do solo quando úmido é não pegajoso e não plástico; muito poroso A estrutura é fraca, solta, friável e se desfaz em pequenos a médios blocos subangulares e grãos simples. ; transição clara e irregular; raízes comuns e finas. Ocorrência de material arqueológico.

A4 $(34 / 37-47 \mathrm{~cm})$ a coloração do solo é $7,5 Y R$ 4/2 úmido. A textura é arenosa. A consistência do solo quando úmido é não pegajoso e não plástico; muito poroso;A estrutura é forte e se desfaz em pequenos a grandes blocos subangulares; transição difusa e plana; raízes raras e finas a médias. Ocorrência de material arqueológico.

AB $(47-63 \mathrm{~cm})$ a coloração do solo é 7,5YR 4/2 úmido e 2,5YR 4/8 úmido, a textura é arenosa. A consistência do solo quando úmido é não pegajoso e não plástico; drenagem imperfeitaA estrutura apresenta aspecto de maciça. . A transição entre horizontes é difusa e plana, há presença de raras e raízes finas. Ocorrência de material arqueológico.

BA $(63-79 \mathrm{~cm})$ a coloração do solo é 2,5YR 4/8 úmido e 7,5YR 4/2 úmido, a textura é arenosa. A consistência do solo quando úmido é ligeiramente pegajoso e ligeiramente plástico; drenagem imperfeita, a estrutura apresenta aspecto de maciça. A transição entre horizontes é difusa e plana, há presença de raízes raras e finas.

B1 $(79-107 \mathrm{~cm})$ a coloração do solo é 2,5YR 4/8 úmido, a textura do solo é argiloarenosa. A consistência do solo quando úmido é pegajoso e muito plástico; mal drenado. A estrutura apresenta aspecto de maciça. A transição entre horizontes é difusa e plana. As raízes são raras e finas nesse horizonte.

B2 $(107150+\mathrm{cm})$ a coloração do solo é 2,5YR 5/8 úmido, a textura é argiloarenosa. A consistência quando solo está úmido é pegajoso e plástico; mal drenado. A estrutura apresenta aspecto de maciça. As raízes são raras e finas nesse horizonte.

\section{Sítio Encontro \\ Sondagem N4 E22}

\begin{tabular}{cccccc} 
Horizonte & profundidade & Areia Grossa & Areia Fina & Argila & Silte \\
\hline A1 & $0-7 / 8 \mathrm{~cm}$ & 34 & 15 & 15 & 36 \\
A2 & $7 / 8-12 / 13 \mathrm{~cm}$ & 60 & 10 & 10 & 20 \\
A3 & $12 / 13-34 / 37 \mathrm{~cm}$ & 58 & 12 & 6 & 24 \\
A4 & $34 / 37-47 \mathrm{~cm}$ & 51 & 19 & 10 & 20 \\
AB & $47-63 \mathrm{~cm}$ & 44 & 18 & 15 & 23 \\
BA & $63-79 \mathrm{~cm}$ & 36 & 13 & 30 & 21 \\
B1 & $79-107 \mathrm{~cm}$ & 24 & 9 & 33 & 34 \\
B2 & $107-150+\mathrm{cm}$ & 37 & 9 & 33 & 21
\end{tabular}

Tabela : resultado da análise da textura do solo, N4E22 


\section{Cronologia e Fases Arqueológicas para o Estado de Rondônia}

A partir de Miller, 1983, 1987, 1992, 1999 e Miller et alli, 1992

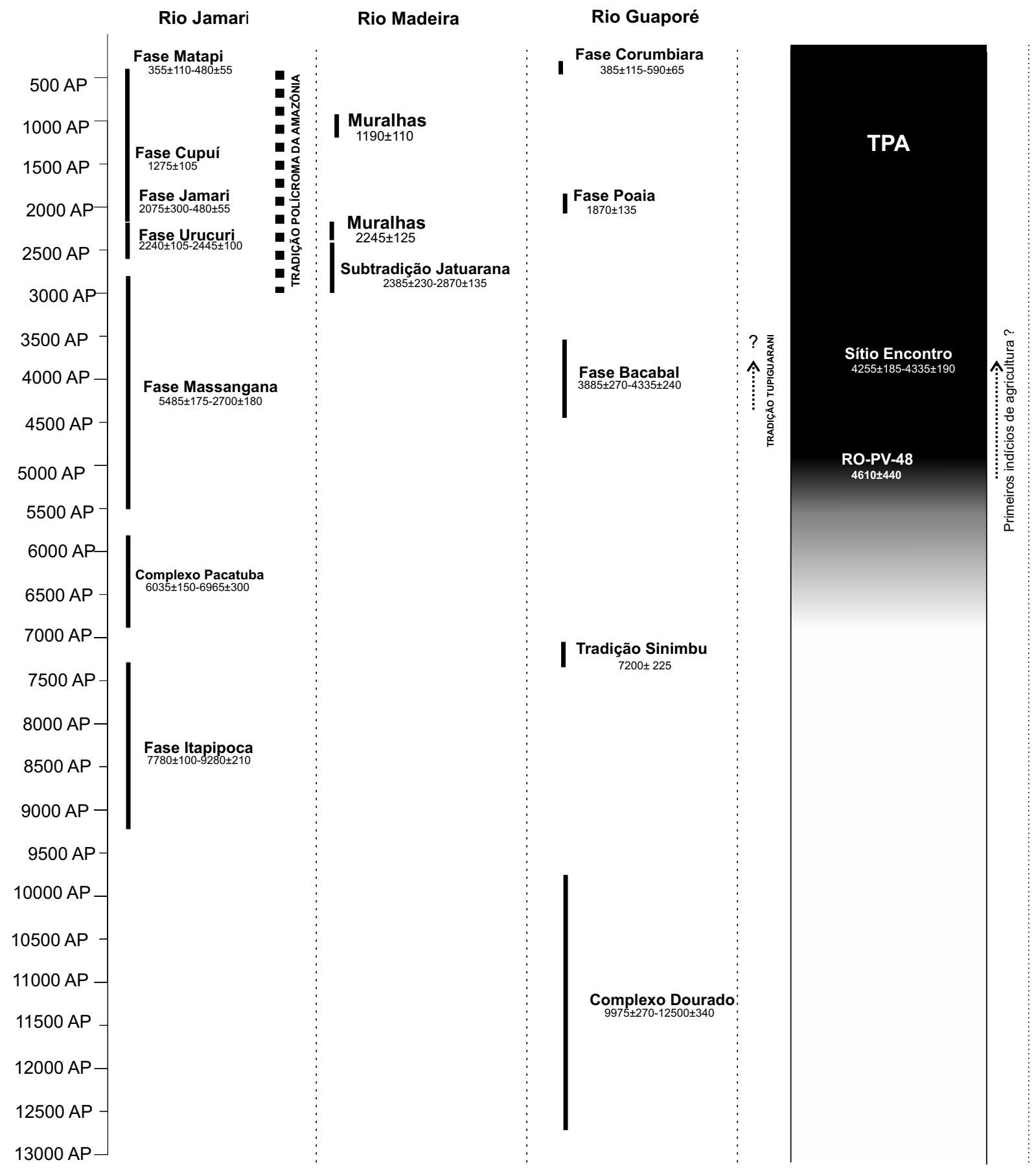

